BERNARDO STROBEL GUIMARÃES

\title{
DA REGULAÇÃO COMO FUNÇÃO DE DIREITO ADMINISTRATIVO
}

Dissertação apresentada como requisito parcial para obtenção do título de Mestre em Direito, do Programa de Pós-Graduação Stricto Sensu em Direito do Estado, da Faculdade de Direito da Universidade de São Paulo.

Orientadora: Prof. ${ }^{a}$ Doutora Maria Sylvia Zanella Di Pietro.

SÃO PAULO 


\section{DA REGULAÇÃO COMO FUNÇÃO DE DIREITO ADMINISTRATIVO}

Dissertação aprovada como requisito parcial para obtenção do grau de Mestre em Direito, do Programa de Pós-Graduação Stricto Sensu em Direito do Estado, da Faculdade de Direito da Universidade de São Paulo pela seguinte banca examinadora:

Orientadora:

Prof. a Dra. Maria Sylvia Zanella Di Pietro.

Departamento de Direito Público - USP

Membros:

Prof. Dr.

Prof. Dr.

São Paulo, de de 2007. 


\section{RESUMO}

O Direito Administrativo vem passando por notáveis mudanças. Dentre elas destaca-se o incremento da regulação. Embora não se apresente como uma novidade completa, a regulação é noção que - sintetizando matrizes da noção de poder de polícia e do conceito de serviço público - tem se insinuado como o modo de atuação do Estado Regulador. O presente trabalho visa a buscar compreender melhor esse fenômeno. Para tanto, primeiramente, analisar-se-ão diversos modelos de Estado e o modo de atuação da Administração neles. Posteriormente, buscou-se conceituar a regulação enquanto instituto, destacando sua previsão constitucional. Por fim, proceder-se-á a análise das finalidades, dos meios de atuação e do controle do exercício da função de regulação. 


\begin{abstract}
The administrative law is going through sensible changes. Among them the increment of the regulation is distinguished. Even though it doesn't shows itself as something completely new, the regulation is the notion that synthesizes matrixes of the notion of police power and the public service concept showing itself as the Regulatory State's way of acting. The following paper will search the comprehension of this phenomenon. In order to achieve that, firstly, various models of State and the way their administration acts will be analyzed. After, the regulation, as an institution, will be explained giving focus to its constitutional predictions. In the end an analysis of purposes, means of acting and the army control of the regulatory function will be conducted.
\end{abstract}




\section{SUMÁRIO}

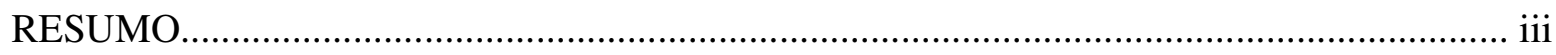

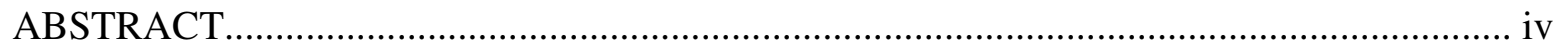

INTRODUÇÃO .............................................................................................................. 1

1 EVOLUÇÃO DA FUNÇÃO ADMINISTRATIVA E ORGANIZAÇÃO DO ESTADO (DO

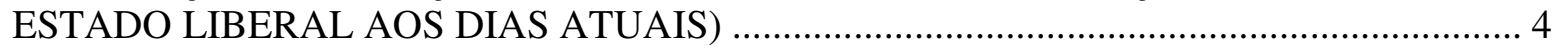
1.1. ESTADO LIBERAL E CARACTERIZAÇÃO DA FUNÇÃO ADMINISTRATIVA

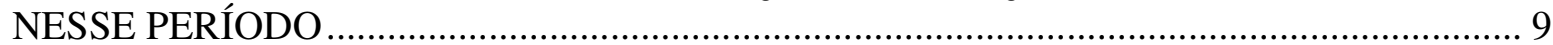

1.2. ESTADO SOCIAL E CARACTERIZAÇÃO DA FUNÇÃO ADMINISTRATIVA ........ 26 1.3. ESTADO PÓS-SOCIAL E CARACTERIZAÇÃO DA FUNÇÃO ADMINISTRATIVA (O MOMENTO DA CRISE)

1.4. SÍNTESE CRÍTICA DA EVOLUÇÃO DO ESTADO (E DA FUNÇÃO ADMINISTRATIVA) À LUZ DOS PRESSUPOSTOS ATUAIS - UM NOVO MODELO DE

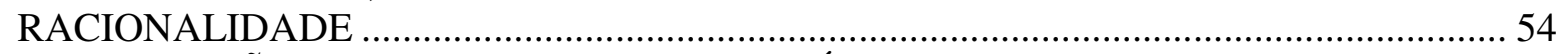

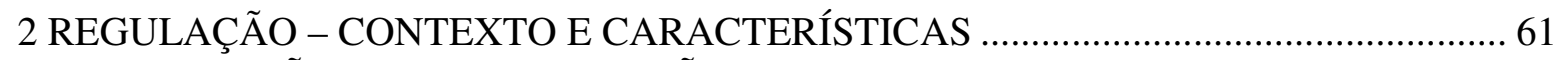

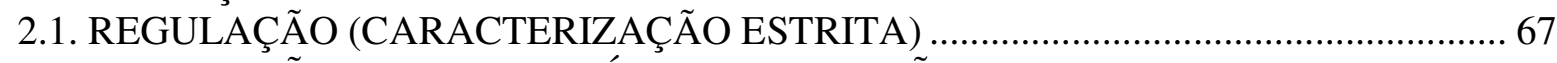

2.2. REGULAÇÃO ENQUANTO SÍNTESE DE NOÇÕES RESTRITIVAS E PRESTACIONAIS .81

2.3. FUNÇÃO DE REGULAÇÃO E A CONSTITUIÇÃO DE 1988 (FUNÇÃO NORMATIVA, EXECUTÓRIA E DE COMPOSIÇÃ̂ DE CONFLITOS) .......................... 93

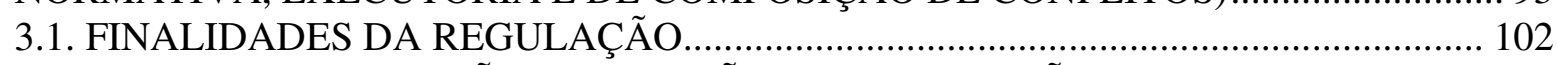

3.2 MODOS DE EXPRESSÃO DA FUNÇÃO DE REGULAÇÃO..................................... 110

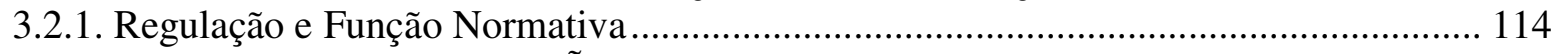

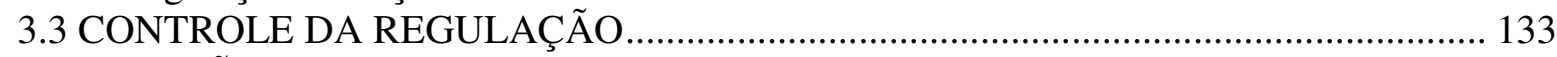

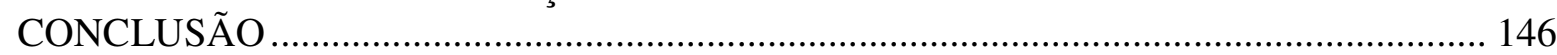

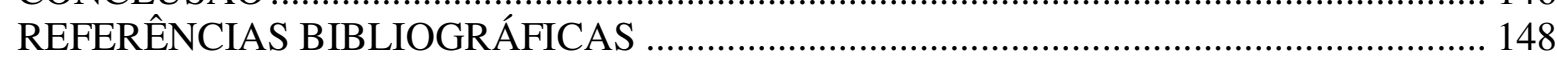




\section{INTRODUÇÃO}

O Direito Administrativo vem sofrendo alterações constantes que põem em causa as categorias utilizadas até o presente momento para explicar a atuação da Administração Pública na concretização do interesse público. A compreensão desse fenômeno é indispensável para a percepção do papel do Direito Administrativo na atualidade.

Todavia, as mutações sentidas não se restringem ao campo de atuação do Direito Administrativo. As dificuldades no trato dessa matéria são sintoma e não causa. Na raiz das modificações que vêm se evidenciando está a modificação da própria concepção do papel reservado ao Estado e seu modo de inter-relacionamento com a sociedade. O Direito Administrativo, disciplina jurídica que rege as manifestações concretas do Estado, serve como caixa de ressonância dessa alteração de paradigmas.

O presente trabalho tem por objetivo lançar algumas luzes sobre esse fenômeno, analisando-o sobre o prisma da regulação. A abordagem proposta no trabalho foca-se em uma premissa que buscou manter-se hígida durante o seu curso, qual seja, analisar a regulação enquanto uma manifestação da relação entre Administração e sociedade, estruturada sobre a forma de função. Procura-se assim possibilitar a análise do exercício da função de regulação em si considerada, sem buscar o fenômeno a partir das estruturas que exercem regulação, chamadas no Brasil de Agências Reguladoras.

Tal pressuposto de trabalho resulta em uma análise dividida basicamente em três partes distintas. Primeiramente, analisar-se-á a evolução do Estado associada a cogitações acerca de como se manifestava o exercício da função administrativa em cada um dos modelos que foram vistos. Após tal análise, proceder-se-á pesquisa acerca da caracterização da regulação, na medida em que o tema não detém um sentido unívoco, especialmente no Brasil em que ainda o tema soa como novidade não sendo de trato corrente na doutrina. Por fim, a partir da definição do contexto do qual emerge a regulação e apontadas suas características elementares, leva-se a efeito cogitações acerca das dimensões associadas a um tratamento funcional do instituto. Assim, cuida-se de definir quais são os objetivos da regulação, os meios pelos quais ela se expressa e, por fim, como se a controla.

Desde o ponto de vista da pesquisa dos supostos históricos implicados com a emergência da regulação serão estudados o Estado Liberal, o Social e o Pós-Social. A análise 
busca destacar, além das características elementares de cada modelo, qual a concepção vigente em cada um deles acerca da função administrativa e o modo pela qual ela se expressava.

Vistos os pressupostos que contextualizam a regulação busca-se trazer quais são as características que definem o instituto. A análise das diversas concepções acerca da regulação vigentes permite que se recolham as características que conformam o instituto. A verificação das distintas dimensões implicadas no conceito de regulação autoriza sua definição operacional nos seguintes termos: atuação com vistas a ordenar determinada atividade econômica para satisfação de interesses públicos que, naturalmente, não seriam atendidos; desempenhada por atos normativos, de execução e de composição de conflitos; assumindo as mais diversas modalidades e configurações, preferindo atos de intervenção indireta e de incentivo sem, todavia, excluir a imposição coercitiva e a intervenção direta; incidindo sobre agentes públicos e privados (i.e. sobre toda atividade econômica) e garantindo, ao máximo, a real alteração dos conteúdos regulados, legitimando-se pelos resultados (eficiência).

Ainda no plano da caracterização da regulação destaca-se que o conceito é uma síntese de concepções restritivas acerca do papel da Administração, aglutinadas ao entorno da noção de poder de polícia e de concepções promocionais reunidas, no grosso, na noção de serviço público. Sob um certo ângulo, a regulação configura uma síntese de noções já conhecidas pelo direito administrativo que visa a ordenar a forma de relação entre Administração e sociedade, no Estado Regulador. Consagrando meios de atuação indireta, buscam-se elementos promocionais associados à atuação da Administração.

Por fim, no que toca à caracterização da regulação busca-se destacar sua inserção no Texto Constitucional. Nesta linha é necessário analisar o art. 174 da Constituição destacando quais são os seus limites e possibilidades. Em especial, destaca-se que o plexo de valores contidos nos princípios que estrutura a ordenação jurídico-constitucional da ordem econômica (em especial no art. 170 da Constituição) exige a atuação estatal de modo a compatibilizá-los entre si de modo harmônico. Eis o campo de incidência por excelência da regulação.

Por fim, proceder-se-á à análise da regulação enquanto estrutura funcional, destacando suas finalidades, seus métodos de atuação e as peculiaridades no seu controle.

Quanto aos fins, vê-se que a regulação caracteriza-se, exatamente pela ausência de definição prévia dos objetivos a serem alcançados. Tendo por missão arbitrar conflitos havidos na exploração das atividades econômicas, compete à regulação ser permeável a diferentes 
demandas não identificando a priori seus objetivos com nenhuma delas. Assim a regulação tem por característica sua abertura a diversas demandas, não assumindo um objetivo previamente definido.

Em relação aos modos de atuação, a regulação caracteriza-se por implicar no manejo de competências que vão além da mera aplicação ex officio de normas a situações concretas. Além da competência administrativa ordinária, estão associadas à regulação à capacidade de compor conflitos surgidos no seu exercício e à capacidade normativa necessária para dar maior densidade aos comandos vertidos em lei.

Quanto ao controle, a regulação não rompe com as formas tradicionais de fiscalização da atuação administrativa, não se limitando a elas, todavia. As técnicas de controle levam em conta às peculiaridades da própria regulação. Tendo em vista que o exercício da função de regulação exige imparcialidade na eleição dos fins e efetividade na implementação das metas fixadas, assume relevo à participação popular no seu controle. Outra dimensão que se agudiza é o controle do procedimento de fixação das diretrizes a serem implementadas.

Basicamente esta é a estrutura pela qual analisar-se-á a regulação no presente trabalho. 


\section{EVOLUÇÃO DA FUNÇÃO ADMINISTRATIVA E ORGANIZAÇÃO DO ESTADO (DO ESTADO LIBERAL AOS DIAS ATUAIS)}

Buscar compreender o exercício por parte do Estado Administração de suas novas tarefas pressupõe, como ponto de partida, uma perspectiva histórica acerca da evolução das missões reservadas ao Estado e um esboço, breve que seja, acerca das suas características.

Isto, pois, distintas concepções de Estado implicam em diferentes conteúdos em relação ao Direito Administrativo. Ou seja, as características da conformação do espaço estatal têm influência decisiva sobre como o Estado desempenha suas missões, matéria de fundo do Direito Administrativo. Sobre o tema, sintetiza com precisão Maria Sylvia Zanella DI PIETRO: "Na realidade, o conteúdo do Direito Administrativo varia no tempo e no espaço, conforme o tipo de Estado adotado". ${ }^{1}$ Com efeito, diferentes concepções acerca do modelo de Estado implicam em distinções no conteúdo reconhecido como o inerente à atividade de Administração.

Logo, não se pode ter a pretensão de compreender o atual estágio da atuação do Estado no desempenho da função administrativa sem se buscarem os pressupostos que conduziram até o momento atual e sem explicitar as marcas peculiares do tempo atual. É necessário então traçar um quadro geral acerca da relação entre o modelo de Estado e as manifestações do direito administrativo para compreender os desafios da contemporaneidade.

Com efeito, as missões reservadas à Administração não são um dado abstrato, sendo condicionados por contingências de tempo e lugar a serem necessariamente consideradas para compreensão do seu alcance. A função administrativa não é uma categoria abstrata, pertencente ao mundo das idéias, dissociada do tecido social que lhe é subjacente. Muito pelo contrário, as missões reservadas à Administração são variáveis, não lhe sendo reconhecido um único conteúdo próprio válido de modo universal, e sim diversas possibilidades, variáveis à luz de critérios historicamente determinados. ${ }^{2}$ Tal variabilidade é fruto da própria natureza do

\footnotetext{
${ }^{1}$ DI PIETRO, Maria Sylvia Zanella. Direito Administrativo. 17. ed. São Paulo: Atlas, 2004, p. 25.

${ }^{2}$ A indefinição de um conteúdo próprio da função administrativa leva, conforme certa linha doutrinária sustenta, inclusive à impossibilidade de se defini-la de modo coerente, devendo adotar-se um critério de índole subjetiva (direito administrativo = direito da Administração, enquanto sujeito de direito). Importa reproduzir a crítica, no sentido de acentuar a indefinição do conteúdo da função administrativa de modo alheio às circunstâncias de tempo e lugar. Neste sentido, anotam Eduardo García de ENTERRÍA e Tomás-Ramón FERNÁNDEZ: "El intento de aislar una abstracta función estatal de administrar, para edificar sobre la misma el objecto formal del Derecho Administrativo como disciplina, ha sido uno de los esfuerzos más prolongados y más sutiles en la
} 
Direito Administrativo que visa a regular a relação entre Estado e cidadão. Como já advertiu Prosper WEIL

O direito administrativo data unicamente do último terço do século passado. É um direito jovem, que sofreu, em menos de cem anos, uma rápida evolução. Cada uma das etapas que ultrapassou marcou-o, aliás, de forma indelével e, embora seja cómodo falar em termos de tempo e crescimento, seria talvez mais exacto evocar uma imagem geológica: a cada uma das idades corresponde uma camada diferente, tal como o direito administrativo actual comporta elementos que remontam a diferentes épocas e, portanto, derivam de concepções muito diversas. A compreensão desse fenómeno é essencial a quem queira conhecer essa disciplina e, melhor ainda, compreender os seus problemas mais fundamentais. ${ }^{3}$

Aliás, ilustrativo considerar que nos sistemas de inspiração francesa julgar a Administração é função administrativa, e não função judicial, o que bem demonstra a relatividade dos conteúdos reservados às diversas funções do Estado.

O exercício da função administrativa será sempre vassalo de uma concepção de Estado definida por determinada Constituição que, ao seu turno, está condicionada pelas circunstâncias de uma dada sociedade em um tempo determinado. ${ }^{4}$ Para compreender então o tema da função administrativa é necessário transitar previamente pelos modelos (estruturas

historia de nuestra ciencia - y también uno de los más baldios -. Administrar sería acción (frente a declaración, como propia de las funciones legislativa y judicial), o acción singular e concreta, o acción organizada, o acción de conformación social, o gestión de los servicios públicos (esta tesis dominó la primera mitad del siglo pasado en Francia), o actuación bajo formas jurídicas peculiares (ato de autoridad primero, acto-condición y acto subjetivo en DUGUIT, actuación ejecutoria etc.). El cansancio de este prolongado esfuerzo dialéctico se manifestó en la sorprendente adopción final de fórmulas exclusivamente negativas: administrar sería toda actuación del Estado distinta de legislar o de enjuiciar (escuela alemana, desde MAYER, que reaparece insólitamente en la Ley norteamericana de Procedimiento Administrativo de 1946), criterio cuyo sentido vendría del hecho de que legislar y juzgar se habrían separado del complejo de funciones del viejo Estado absoluto como simples técnicas formales, en tanto que el resto -un conglomerado o aluvión histórico, donde se mezclan funciones e competencias heterogéneas- no es reductible a ninguna técnica formal uniforme; o tesis de la 'regla o cláusula exorbitante', desempolvada en Francia (porque tiene un claro origen absolutista: los derechos del Príncipe exorbitant a jure commune; nuestras Cortes de Valladolid de 1442 protestan ante el Rey de que en las Reales Cartas 'se ponen muchas exorbitancias de derecho'; en la Ley 7., , Título V, Libro III, de la Novísima Recopilación, se habla de las Cartas Reales ' que las mandamos dar de nuestro proprio motu y poderío Real absoluto, con otras exorbitancias') tras la crisis de la doctrina de servicio público, en la última postguerra, y que se limita a catalogar en el Derecho Administrativo las regulaciones Estado-ciudadanos que sale (por arriba e por abajo; privilegio en más y en menos: RIVERO) de los moldes establecidos del Derecho Privado, renunciando a una explicación uniforme de esa peculiaridad." (In Curso de Derecho Administrativo I, 12. ed, Madrid: Thomson Civitas, 2005, p. 30-31.)

${ }^{3}$ WEIL, Prosper. O Direito Administrativo. Coimbra: Almedina, 1977, p. 11.

${ }^{4}$ Sobre o tema, anota com propriedade Konrad HESSE (na tradução de Gilmar Ferreira MENDES): "Em síntese, pode-se afirmar: a Constituição jurídica está condicionada pela realidade histórica. Ela não pode ser separada da realidade concreta de seu tempo. A pretensão de eficácia da Constituição somente pode ser realizada se se levar em conta essa realidade. A Constituição jurídica não configura apenas a expressão de uma dada realidade. Graças ao elemento normativo, ela ordena e conforma a realidade política e social. As possibilidades, mas também os limites da força normativa da Constituição resultam da correlação entre ser (Sein) e dever ser (sollen)." (In A Força Normativa da Constituição, Porto Alegre: Fabris, 1991, p. 24). 
condicionantes) que a conformam, o que remete à análise prévia de determinado modelo de Estado, na medida em que ele condiciona variáveis jurídicas e sociais. ${ }^{5}$

Se é certo que é característica da Administração exercer a chamada função administrativa, ${ }^{6}$ é de se ver que a definição do que é efetivamente tal elemento não é tão simples de ser feita, especialmente, em se considerando as variáveis espaço e tempo. Caracterizações formais acerca do que seja função administrativa, embora atendam a reclames didáticos não dão conta de explicar a atuação efetiva da Administração Pública.

Com efeito, diferentes modelos de organização social e jurídica levam a diferentes concepções acerca das missões reservadas à Administração, o que deve ser considerado ao tratar do tema, sob pena de se cometerem graves equívocos decorrentes da perda de uma perspectiva de continuidade. Embora possa se buscar uma unidade conceitual para o conceito de função administrativa é de se ver que, por baixo dessa categoria unificante, diversos conteúdos podem ser concebidos. Os desafios que se colocam a um Estado que admita como pressuposto de legitimidade sua atuação sobre a ordem privada conduzem a uma concepção efetiva de função administrativa distinta da que se colocaria se o pressuposto da legitimidade da intervenção fosse retirado.

Não é só. A função administrativa é concretizada por meio de diferentes técnicas (atividades) que visam exatamente a fazer a ligação entre o conceito abstrato de função administrativa e o tipo de atuação concreta que se espera do Estado com vistas a atender

\footnotetext{
5 Referendando esse método, na doutrina nacional tem-se, dentre vários, Floriano Peixoto de Azevedo MARQUES NETO: “(...) não nos parece possível para os autores que trabalham o Direito Público superar seus impasses sem dar alguma atenção às transformações por que passa o Estado." (In Regulação Estatal $e$ Interesses Públicos, São Paulo: Malheiros, 2002, p. 14.)

${ }^{6}$ Função de um modo geral é a forma de inter-relacionamento jurídico que pressupõe a atribuição de prerrogativas em vista do atingimento de um fim. É conceito inerente à atividade desenvolvida pela Administração, que atua interesses que não são capazes de ser titularizados por ela sendo, em verdade, institucionalmente coletivos. $\mathrm{O}$ assunto mereceu tratamento detido de Renato ALESSI, em obra que repercutiu sobremaneira na concepção usual acerca do tema havida na doutrina nacional. Para o autor italiano, em síntese, é característica elementar da atividade desenvolvida pela Administração sua sujeição ao atendimento dos interesses coletivos, constituindo-se em verdadeiro dever de desenvolver o ordenamento jurídico em prol da coletividade. Tal atividade caracteriza-se pela incapacidade de inovar a ordem jurídica, sendo acessória à lei que tem o condão de inovar de modo primário a ordem jurídica sendo que o ente que a exerce passa a ser parte da relação. A administração (i.e. o exercício de função administrativa), traduz atividade dotada de supremacia em relação aos particulares (decorrente de sua missão de garantir interesses coletivos) o que se traduz na possibilidade de imposição de deveres unilateralmente. Vale a lógica de superioridade do sujeito público sobre o privado legitimada pelo dever de atender aos fins coletivos, considerados superiores a quaisquer outros interesses. Para uma síntese acerca do pensamento do autor consulte-se: ALESSI, Renato. Instituiciones de Derecho Administrativo, Tomo I, Barcelona: Bosch, 1970, p. 6-25. Como se percebe, a exposição deste autor acerca do conteúdo da função administrativa corresponde ao usualmente indicado pela doutrina nacional sobre o tema.
} 
demandas específicas. A atividade de administração (i.e. o exercício da função administrativa ou administração em sentido objetivo) é integrada por diversas formas de atuação. ${ }^{7}$ É natural que se aluda ao Poder de Polícia para designar as atuações da função administrativa destinadas a restringir o patrimônio dos particulares bem como se invocar o serviço público como categoria apta a explicar manifestações em que há ampliação do rol de direitos outorgado pela Administração aos privados. Todavia, os regimes jurídicos referentes a tais manifestações são absolutamente distintos, malgrado, ambos configurem exercício de função administrativa. A própria diversidade de técnicas acerca da implementação da chamada função administrativa demonstra a ausência de possibilidade de se trabalhar com ela como uma categoria lógica dotada de validade universal, capaz de orientar atemporalmente a solução dos problemas efetivos havidos na atuação do Estado.

Assim, um estudo sobre o exercício atual da função administrativa de regulação (como se objetiva o presente) não deve se furtar a dispensar alguma atenção à figura do Estado e das transformações pelas quais ele vem passando. Trabalhar sem essa explicitação prévia dos pontos de partida só pode supor haver uma identificação perfeita das categorias necessárias ao estudo da função administrativa, estando-se diante de um paradigma ${ }^{8}$ além de qualquer disputa. Não é o caso dos dias de hoje, em que longe se faz qualquer consenso unânime, o que impõe a necessidade de se meditar acerca do modelo atual de Estado para compreender as categorias do direito administrativo.

Logo, é necessário analisar o tema em uma perspectiva que privilegie a visualização das diversas manifestações da atuação administrativa.

O esforço de analisar os principais modelos de Estado e o conteúdo da função administrativa a eles subjacentes antes de ser levado a efeito pressupõe algumas explicitações de método.

Primeiramente, cumpre aludir que a análise se pauta sobre modelos gerais, que buscam trazer, de modo genérico, e sem uma contextualização precisa, as principais características dos diversos momentos pelos quais passou o Estado até chegar aos dias de hoje. Não há a identificação absoluta dos modelos referidos abaixo com nenhuma situação real, havida na

\footnotetext{
${ }^{7}$ O rol de tais tarefas específicas varia de acordo com nossos tratadistas. Apenas para exemplificar Maria Sylvia Zanella DI PIETRO divide administração em sentido objetivo em quatro atividades distintas: polícia administrativa, serviço público, fomento e intervenção (in Direito..., p. 59-60.)

${ }^{8}$ Está-se a se tomar o vocábulo na acepção consagrada por Thomas KHUN, in A Estrutura das revoluções científicas. 8. ed., São Paulo: Perspectiva, 2003.
} 
experiência concreta, cuida-se de mera abstração didática alheia a contingências definidas de espaço e tempo. Tratam-se de representações ideais, exacerbadas em suas características mais evidentes para fins didáticos e a bem da unidade de compreensão do tema.

Mais ainda, na análise procedida deixaram-se de lado algumas nuances que poderiam ser exploradas e mesmo sobre os pontos abordados de um modo mais explícito haveria, sem dúvida, muito mais a se dizer. Contudo, privilegiou-se uma análise dos aspectos fundamentais dos diversos modelos, mais intimamente relacionados com o exercício da função administrativa e sua tradução concreta, que permitissem um quadro geral apto a suportar as análises mais específicas a serem procedidas no correr do trabalho acerca da regulação. Fugiuse das minúcias em prol da definição de um quadro mais geral, capaz de demonstrar as modificações mais importantes no exercício da função administrativa e como ela se concretiza em modelos diversos.

O corte metodológico visou a deixar mais vincada uma evolução global, didaticamente mais adequada, em detrimento de uma análise mais específica, pois, o tema de fundo não é o Estado e seus modelos jurídicos, e sim o atual exercício da função administrativa, aglutinada ao redor da idéia de regulação. Assim, a presente análise não é um fim em si mesmo e tem o intuito de proceder a uma contextualização reputada absolutamente necessária para a análise dos pontos a serem tratados durante a exposição acerca da regulação.

Outra explicitação formal a ser feita, diz com o fato de que a emergência de um modelo de Estado não induz à suplantação absoluta do esquema anterior. No curso da evolução (especialmente em direito), geralmente, não se operam transformações radicais sendo a alteração de modelos lenta e gradual. Inclusive, a separação procedida cuida de mera divisão arbitrária/convencional e não configura um corte absolutamente preciso entre realidades díspares. Não há uma linha divisória precisa entre os modelos, sendo que eles se interpenetram e convivem em sintonia em períodos de transição. É assim que marcha a história, salvo nos momentos de efetiva revolução.

Certas características são conservadas ao longo da evolução sendo salvaguardadas mesmo na emergência de novos paradigmas, embora adaptadas a força das novas circunstâncias. ${ }^{9}$ Assim, o Estado Social incorpora conceitos de garantia dos cidadãos hauridos

\footnotetext{
${ }^{9}$ Neste sentido : "Afirmar que el Derecho Administrativo de los comienzos del siglo XXI se nutre de técnicas marcadamente distintas del que se elaboró al empezar el siglo XIX, con el primer constitucionalismo, es seguramente una obviedad. Por supuesto, muchas instituciones básicas que lo identifican como rama autónoma
} 
do Estado Liberal, bem como o Estado Pós-Social, além de repercutir essas características mais antigas, não rompe com a lógica de atuação do aparato estatal em prol do bem comum. Trata-se de um contínuo e não de cortes bruscos ou absolutamente revolucionários. Mesmo os instrumentos de atuação presentes em cada momento ainda se preservam, acrescentando-se a velhos institutos novas figuras (sem prejuízo de um ou outro ser descartado pela evolução social). Ou seja, certas linhas são contínuas na evolução dos modelos e isso precisa ser destacado, sob pena de se tomar a evolução como encerrando quebras de sequiência, o que sabidamente não se verifica no campo ora em análise. Afinal, como adverte Santiago Muñoz MACHADO: "Esta ciencia del Derecho Administrativo, como todas, no se forman en base a cortes radicales que declaren la derogación total de lo creado, sino poco a poco, mediante sumas de esfuerzos y aportaciones que innoven, expliquen y den respuesta a los novos problemas." 10

Outra advertência é em relação à existência de nomenclaturas diversas em relação aos diferentes modelos tratados e mesmo classificações distintas. No presente trabalho, optou-se por utilizar-se a nomenclatura Estado Liberal, Social e Pós-Social, que permite uma boa visualização das características que se pretendem examinar em relação à função administrativa e seus desdobramentos. As principais notas a serem acentuadas ficam destacadas nessa classificação. Julgou-se mais útil esse corte para encarecer os aspectos a serem analisados. Todavia, outras denominações seriam possíveis e mesmo uma divisão distinta, em face de se colocar o tônus da análise em outras categorias.

Feitas essas ressalvas é que se passa a apresentar um panorama sobre os modelos de Estado e o modelo jurídico que lhes é subjacente.

\subsection{ESTADO LIBERAL E CARACTERIZAÇÃO DA FUNÇÃO ADMINISTRATIVA NESSE PERÍODO}

permanecen. Pero los cambios han sido intensos (...) Sus grande instituciones han estado próximas a la evolución constitucional." (MACHADO, Santiago Muñoz Tratado de Derecho Administrativo y Derecho Público General, Tomo I, Madri: Thomson-Civitas, 2004, p. 82.)

${ }^{10}$ Ibidem, p. 84. 
O direito administrativo é fruto de concepções liberais que deram ensejo ao surgimento do Estado de Direito ${ }^{11}$, adaptando as velhas estruturas administrativas ao ideário das revoluções burguesas. ${ }^{12}$ Embora seja claro que alguns institutos do Estado Absoluto ainda se mantiveram por ensejo da afirmação do ideário liberal, tal concepção empresta foros de originalidade ao tema. ${ }^{13}$

É no exato momento em que o exercício do poder se torna submetido à lei (legalidade), se afirma a inviabilidade do seu exercício pleno de modo individual (separação dos poderes) e se admite um patrimônio jurídico dos cidadãos salvaguardado da intervenção estatal (direitos fundamentais), que se pode cogitar de um direito administrativo em sentido próprio. Historicamente, os requisitos para que se implementem essas condições se dão com as

\footnotetext{
${ }^{11}$ Estado de Direito é locução que comporta diversas possibilidades de significado e até algumas críticas (v.g. a identificação de Estado e Direito, de matriz kelseniana). A locução está aqui tomada no seguinte sentido "(...) é possível reservar a expressão Estado-de-Direito para designar a situação criada pelas revoluções demoliberais burguesas e pelo constitucionalismo. Temos então o Estado-de-Direito como aquele em que o limite e o fundamento da ação estatal se encontram na ordem jurídica e essencialmente, na base desta, a constituição. (...) No plano institucional, o liberalismo significou a construção de um Estado em que o poder se fazia função do consenso, e em que a divisão de poderes se tornava princípio obrigatório; o direito prevalecia em seu sentido formal e a ética social repudiava as intervenções governamentais." (Nelson SALDANHA. Formação da Teoria Constitucional. 2. ed. Rio de Janeiro: Renovar, 2000, 19-21.)

${ }^{12}$ Usualmente, segundo Odete MEDAUAR, a origem do direito administrativo é atribuída à edição de diploma normativo que versava acerca da organização administrativa e sobre a solução de litígios em face da Administração (lei do 28 pluvoise do ano VIII, i.e. 1800). Em relação à organização, os vetores da citada lei eram a centralização e a hierarquização, quanto à solução de litígios valia a chamada justiça retida (decisões eminentemente consultivas e não vinculativas para quem estivesse no ápice da estrutura administrativa). Além da edição da referida lei, que obviamente exerce influência decisiva para a afirmação autônoma do direito administrativo, é de se levar em conta a elaboração dos primeiros estudos sistemáticos acerca do tema e da criação de cátedras para seu estudo em diversos países da Europa. Neste sentido e fazendo um interessante apanhado sobre o tema "origem do direito administrativo" consultar MEDAUAR, Odete. O direito administrativo em evolução. São Paulo: RT, 2003, p. 13-28.

${ }^{13}$ Sobre o tema anota Maria Sylvia Zanella DI PIETRO: "O Direito Administrativo, como ramo autônomo, nasceu em fins do século XVIII e início do século XIX, o que não significa que inexistissem anteriormente normas administrativas, pois onde quer que exista o Estado, existem órgãos encarregados do exercício de funções administrativas. $O$ que ocorre é que tais normas se enquadravam no jus civile, da mesma forma que nele se inseriam as demais, hoje pertencentes a outros ramos do direito (...) a formação do Direito Administrativo, como ramo autônomo, teve início, justamente com o direito constitucional e outros ramos do direito público, a partir do momento que começou a desenvolver-se - já na fase do Estado Moderno - o conceito de Estado de Direito, estruturado sobre o princípio da legalidade (em decorrência de que até mesmo os governantes se submetem à lei, em especial à lei fundamental que é a Constituição) e sobre o princípio da separação de poderes, que tem por objetivo assegurar a proteção dos direitos individuais, não apenas nas relações entre particulares, mas também entre estes e o Estado. Daí a afirmação de que o Direito Administrativo nasceu das Revoluções que acabaram com o velho regime absolutista que vinha da Idade Média." (In Direito.., p. 23-24.) Também interessante consultar sobre o assunto, da mesma autora, Discricionariedade Administrativa na Constituição de 1988. 2. ed. São Paulo: Atlas, 2001, p. 17-28.
} 
revoluções burguesas, sendo digna de nota a Revolução Francesa, haja vista a importância desse modelo para o direito continental-europeu (e por decorrência para o brasileiro). ${ }^{14-15}$

Dessa matriz derivam uma série de categorias caras ao Direito Administrativo, sendo seus elementos primeiramente concebidos ao lume desse referencial teórico. Os primeiros passos na regulação das atividades da Administração ocorrem tendo por pano de fundo concepções do Estado Liberal (talvez a mais relevante delas seja o próprio princípio da legalidade ${ }^{16}$ ), calcadas na proteção de um patrimônio jurídico inalienável dos cidadãos.

É a emergência do modelo liberal que assenta as bases que permitem o surgimento do Direito Administrativo, fixando as balizas originárias que pautaram o exercício da função administrativa. Sobre esse momento histórico e o surgimento desta matéria, anota Maria João ESTORNINHO: "Este nascimento do Direito Administrativo insere-se perfeitamente no contexto da 'visão liberal do mundo' assente na separação entre o Estado e a Sociedade, por

\footnotetext{
${ }^{14}$ Sobre o tema, anota Caio TÁCITO: "O Direito Administrativo surgiu como disciplina jurídica autônoma em época relativamente recente. Até a reforma política decorrente da Revolução Francesa, não se podia caracterizar a independência científica dos preceitos reguladores da atividade administrativa do Estado. Por certo, muito antes desse marco cronológico existiam normas jurídicas sobre a organização e a execução de serviços públicos. Faltava-lhes, porém, a unidade de tratamento, de objeto e de método. É evidente que a tarefa administrativa procedeu ao Direito Administrativo. Todo grupo social, mesmo primitivo e embrionário, exerce funções de administração. A disciplina da vida comum, as necessidades essenciais de defesa e manutenção da coletividade conduzem a um processo administrativo, embora rudimentar. Não se encontra, porém, do sistema jurídico destas relações a subordinação simultânea do indivíduo e do Estado ao império da lei." (Evolução História do Direito Administrativo - notas de aula, in Temas de Direito Público, Rio de Janeiro: Renovar, 1997, v. 1, p. 1.)

${ }^{15}$ Há na doutrina um acalorado debate sobre a origem do direito administrativo, em especial se ele seria um produto exclusivo da revolução francesa, ou disciplina que teria suas bases ainda no Antigo Regime haja vista terem sido mantidos esquemas deste modelo após 1789. Sobre o tema disputam vários autores da maior suposição, parecendo adequada a síntese proposta por Odete MEDAUAR: "Melhor se configura orientação que leva em conta os dois aspectos sem extremos, para vincular o direito administrativo à Revolução Francesa e termos de princípios, não em virtude da origem de um tipo de organização; e para levar em conta noções e mesmo práticas do Antigo Regime acolhidas em parte pelo direito em formação, embora em outro contexto sociopolítico". (Op. cit., p. 21.) Sem prejuízo da existência da controvérsia, importa assinalar que para fins da presente análise adota-se como premissa a relação íntima entre Direito Administrativo e Estado Liberal, pois é neste momento que se lançam as categorias fundamentais da matéria, que repercutem até os tempos modernos. Em especial, legalidade e separação dos poderes são pressupostos necessários para compreender o tema, bem como não se pode compreendê-lo sem admitir que o administrado ocupa uma posição jurídica a ser considerada quando do exercício das potestades estatais (o que se dá com o Estado Liberal e seu individualismo).

${ }^{16}$ Sobre a importância transcendente da legalidade liberal para a afirmação do Direito Administrativo, anota Caio TÁCITO: "O episódio central da história administrativa no século XIX é a subordinação do Estado ao regime de legalidade. A lei, como expressão da vontade coletiva, incide tanto sobre os indivíduos como sobre as autoridades públicas." Evolução histórica do direito administrativo - notas de aula in Temas de Direito Público. Rio de Janeiro: Renovar, 1997. v. I, p. 2.
} 
forma a garantir a propriedade e intimidade, valores fundamentais que o liberalismo procura preservar a todo custo." 17

Então, para se compreender algumas das atuais características do exercício da função administrativa, indispensável partir de categorias forjadas ainda sob o signo do liberalismo, que legou as matrizes sobre as quais se instrumentaliza o Direito Administrativo. ${ }^{18}$ Afinal, como anota Vasco Manuel Pascoal Dias Pereira da SILVA:

A cristalização do modelo de Estado liberal em conceitos jurídicos, que foi sobretudo obra das diferentes correntes positivistas, vai ter como conseqüência a perpetuação dessas teorizações dogmáticas, mesmo para além das realidades histórico-políticas que justificaram a sua criação. Os conceitos jurídicos ganham uma vida própria e adequam-se a realidades distintas, mantendo-se mesmo quando os sistemas teóricos em que se integravam são abalados e se desmoronam. ${ }^{19}$

Ou seja, as categorias jurídicas liberais subsistem à própria superação do Liberalismo como força político-jurídica. Assim, faz-se necessário transitar por esse modelo para compreender o referencial teórico que levou ao surgimento da matéria e a definição de suas primeiras categorias, a partir das quais ela evoluiu até os dias correntes.

Em brevíssima síntese, pode se caracterizar o Estado Liberal da seguinte forma:

O Estado Liberal nasce sob o signo de liberdade do cidadão. Limitando o poder absoluto do Estado, afirma os direitos individuais e políticos. A ordem econômica se fundamenta no princípio da liberdade de iniciativa e de comércio, assegurando o florescimento da burguesia e a disseminação do regime capitalista. A ação do Estado visa a facilitar e garantir o livre jogo dos negócios, tendo como base jurídica a autonomia da vontade, em que se apóia a liberdade de contrato e de associação. ${ }^{20-21}$

\footnotetext{
${ }^{17}$ ESTORNINHO, Maria João. A Fuga para o Direito Privado - Contributo para o estudo da actividade de direito privado da Administração Pública, Coimbra: Almedina, 1999, p. 31.

${ }^{18}$ Sobre o tema (encarecendo também o elemento autoridade, ao lado da liberdade, patrimônio jurídico dos cidadãos), anota Floriano Peixoto de Azevedo MARQUES NETO: "Desta íntima vinculação do Direito Administrativo com a específica configuração do poder político própria à Modernidade advém todo um arcabouço de normas, princípios, métodos e pressupostos que constituem esse ramo do juspublicismo. A síntese de todos esses pressupostos teóricos irá conformar o que ousaríamos chamar de 'paradigma prevalecente do Direito Administrativo', diretamente dependente e relacionado ao modelo de Estado que o constitui, em suas relações com os administrados, o objeto e o objetivo desse ramo jurídico." (Op. cit, p. 61.)

19 SILVA, Vasco Manuel Pascoal Dias Pereira da. Em busca do acto administrativo perdido, Coimbra: Almedina, 2003, p. 69.

${ }^{20}$ TÁCITO, Caio. Do Estado Liberal ao Estado do Bem-estar Social, in Temas de Direito Público. v. 1. Rio de Janeiro: Renovar, 1997, p. 377.

${ }^{21}$ Valendo-se da enunciação mais analítica de Diogo Freitas do AMARAL podem ser apresentadas como características gerais do modelo liberal: (a) concomitância ao surgimento das repúblicas ocidentais; (b) adoção do constitucionalismo como técnica de limitação ao poder; (c) reconhecimento da existência de direitos do homem; (d) proclamação da igualdade jurídica, independente de critérios pessoais; (e) afirmação da soberania da Nação e não do príncipe; (f) surgimento de partidos políticos; (g) subordinação do Estado à lei; (h) reforço das garantias individuais e (i) adoção de predicados liberais em relação à economia. (In Curso de Direito Administrativo. v. I. Coimbra: Almedina, 1992, p. 77.)
} 
Fundamentalmente, a idéia de um espaço de liberdade para o cidadão como limite ao poder estatal (essencialmente em relação à organização da vida social) é a nota elementar do pensamento liberal, cuja preocupação fundamental era o controle do Estado como garantia dos indivíduos. Esse instituto vai instrumentalizar uma série de elementos jurídicos que visam a conter o poder do Estado bem como garantir a liberdade do cidadão. Visto de modo ainda tênue no que consiste o Estado Liberal, importante começar a esmiuçar essa noção do ponto de vista jurídico, de modo a vir a compreender como se desenvolve nele a função administrativa.

Desde o ponto de vista liberal, o modelo jurídico vigente à luz desse paradigma assenta-se, no dizer de Luís S. Cabral de MONCADA, em dois postulados essenciais: (i) a separação absoluta entre direito público e direito privado e (ii) predomínio da autonomia da vontade privada na esfera econômica. ${ }^{22}$ Cumpre explicitá-los para deles extrair o seu alcance para a concepção da função administrativa.

O primeiro dos postulados decorre diretamente da concepção liberal de um espaço íntimo incapaz de ser objeto de disposição pelo Estado. Nessa esfera íntima de interesse, o Estado não deveria atuar de modo direto e sim garantir as condições para que cada pessoa, individualmente, satisfizesse os seus interesses, sem ingerência externa de ordem alguma. Essa nota do Estado Liberal implica em uma absoluta cisão entre Estado e sociedade, ${ }^{23}$ cabendo à ordenação estatal apenas e tão só dar as garantias para que individualmente as pessoas perseguissem o que julgavam melhor para si, livre de interferências.

Esta divisão, que se opunha a concepções unitárias da idade média, é pressuposto da noção moderna de liberdade, como margem de autonomia de atuação individual frente ao Estado. $^{24}$ Cumpre assinalar que o campo reservado com absoluta exclusividade à iniciativa privada era a gestão da vida econômica, da qual o Estado encontrava-se proscrito. Sobre o tema anota Luís S. Cabral de MONCADA: “A ordem jurídica da actividade económica restringia-se pois ao direito privado. O mesmo é dizer que o modelo jurídico do estado liberal

\footnotetext{
${ }^{22}$ MONCADA, Luís S. Cabral. Direito Econômico. 3. ed. Coimbra: Coimbra, 2000, p. 14-24.

${ }^{23}$ Sobre a importância da dicotomia Estado/sociedade no Estado Moderno, consultar Floriano Peixoto de Azevedo MARQUES NETO. Op. cit. p. 41-50.

${ }^{24}$ PIÇARRA, Nuno. A Separação dos Poderes como Doutrina e Princípio Constitucional - um contributo para o estudo das suas origens e evolução, Coimbra: Coimbra, 1989, p. 144.
} 
limitava ao mínimo o direito público restringindo a sua esfera de influência ao tratamento de questões que nada tinham que ver com a actividade económica." 25

Intimamente associada a essa concepção dual entre Estado e sociedade (que se reflete na dicotomia direito público e direito privado), tem-se a outra característica do modelo jurídico do liberalismo, qual seja, a absolutização da autonomia da vontade. Cumprindo ao Estado somente garantir o exercício livre das potencialidades individuais, é na articulação desprendido dos interesses dos privados em que reside a mola mestra da atuação social. Ao Estado não cumpre promover missão outra que não garantir, sem maiores embaraços, que os cidadãos atuem individualmente, em proveito próprio.

$\mathrm{Na}$ soma e síntese das diversas atuações individuais surge o mercado livre, ${ }^{26}$ instância reguladora máxima da economia liberal. ${ }^{27}$ Neste ambiente, era a autonomia da vontade que incumbia regular os interesses da sociedade e promover o progresso e o bem-estar geral ${ }^{28}$, cabendo a ela tutela favorecida (implementada por uma concepção absoluta da força obrigatória dos contratos). Cumpre encarecer que é missão reservada aos atores privados (por

\footnotetext{
${ }^{25}$ MONCADA, Luís S. Cabral. Op. cit, p. 15.

${ }^{26}$ Sobre o tema, anota Luís S. Cabral de MONCADA: "O lugar privilegiado para a manifestação da liberdade individual na esfera económica é o mercado. Este configura-se como um sistema de confronto e harmonização de interesses individuais baseado em regras próprias, impermeáveis à vontade do estado" (Ibidem, p. 16).

${ }^{27}$ Desde o prisma econômico, o Estado Liberal se caracteriza pela já consolidação do capitalismo possibilitada pela acumulação de riquezas e o rompimento com o modo de produção focado em corporações de ofício típico da Idade Média, florescendo as primeiras indústrias fomentadas pela evolução tecnológica do período (para a evolução do capitalismo em geral consulte-se: Antônio José Avelãs NUNES. Os sistemas econômicos, Coimbra: Coimbra, 1994.) Desde o ponto teórico, o liberalismo no campo econômico se funda na concepção, sintetizada por Adam SMITH, que a livre ordenação das forças que atuam sobre os mercados, alheias a qualquer interferência externa (promovidas pelo Estado, em especial) é o meio capaz de gerar o bem comum. É, pois, a soma das ações individuais que possibilita o melhor para a sociedade, sendo que o Estado apenas deve garantir a livre atuação das forças privadas. Na síntese promovida por Antônio José Avelãs NUNES: “As propostas de Adam SMITH, baseadas na idéia de que qualquer indivíduo, desde que respeite as regras da justiça, é livre de lutar pelo seu próprio interesse, aplicando sua 'indústria' e o seu capital na concorrência com os outros, foram, durante longo período, considerados adequadas à realidade, porque capazes de 'fornecer a melhor solução para qualquer questão relacionada com a história do comércio e com o sistema de economia política'." (In Adam Smith e a teoria da distribuição do rendimento, Coimbra: Coimbra, 2003, p. 7). Assumia assim valor a noção de mercado como locus para o desenvolvimento de tais relações. Desde um foco econômico, o mercado era visto como uma instância ordenadora das atividades que possibilitava que a soma dos interesses individuais de cada um gerasse a maior utilidade para todos ao determinar o máximo da produção e a repartição dos bens (distribuição) Em última instância, o fim do Estado liberal (e seu corolário em matéria econômica) é a liberdade dos indivíduos que garantiria todas as expectativas sociais em matéria de economia.

${ }^{28}$ Novamente, nos socorrendo da lição de Luís S. Cabral de MONCADA: "Não são actos excepcionais de altruísmo privado, mas o sistema da livre concorrência alicerçada numa ordem jurídica contratual segura que canalizam as energias individuais para a produção e para a inventiva, cimentando assim cumulativamente a prosperidade geral." (Op. cit, p. 17.) Veja-se que, neste sentido, é incorreto anotar que o pensamento liberal não tinha a preocupação com o progresso e bem estar sociais. Há a preocupação, sim, com o progresso da sociedade; todavia, esta missão não está confiada ao Estado e sim aos próprios particulares.
} 
meio de seus interesses individuais) impulsionar a vida econômica, sendo o Estado alheio a esse campo (atuando como mero garante desse jogo, que pressupõe a liberdade de seus atores). Todavia, é de se destacar que mesmo no Estado Liberal a separação entre Estado e economia não é absoluta, sendo muito mais um objetivo ideal. Mesmo os maiores próceres do liberalismo, reconhecem que atividades que sejam de interesse coletivo que, no entanto, não sejam capazes de atrair a indústria privada devem ser reservadas ao Estado (fundamentalmente a criação de infra-estrutura submete-se a essa lógica). ${ }^{29}$

Na síntese de Maria Sylvia Zanella DI PIETRO - "A posição do Estado era fundamentalmente negativa, pois ele não devia ofender os direitos e liberdades inalienáveis do indivíduo, sem intervir na ordem social ou na economia.",30

É à luz de tais referenciais que se pode buscar compreender o exercício da função administrativa no Estado Liberal.

A nota predominante em sua caracterização é sua baixa intensidade (considerado o referencial atual) em face da virtual intangibilidade do patrimônio jurídico dos cidadãos, que operava como limite negativo à atuação do Estado, demarcando um espaço amplo que lhes era próprio (e constituía limite à atuação estatal). É esse espaço de limitação à atuação estatal (correspondente a um espaço de livre atuação do particular sobre a autonomia da vontade o que implica em distinção estanque entre o público e o privado) que vai dar ensejo às técnicas utilizadas pelo ideário liberal para controlar o Estado. São técnicas jurídicas que visam a garantir a liberdade dos particulares no período liberal: a separação dos poderes e a legalidade, ambas legadas desta época para a posteridade (ainda que submetidas à evolução dos tempos), fortemente associadas e tributárias de um ideário comum desse período. ${ }^{31}$

\footnotetext{
${ }^{29}$ A separação absoluta do Estado da economia é muito mais uma afirmação geral e mesmo caricatural do que uma verdade absoluta. Nunca houve um absenteísmo completo em relação à vida econômica. Diferentes modelos contaram com a atuação do Estado na economia mesmo nos momentos áureos do liberalismo. Para uma indicação bibliográfica a respeito e uma menção a tarefas que nunca estiveram exclusivamente a cargo dos particulares, consulte-se Odete MEDAUAR (Op. cit., p. 81-82). Note-se que o próprio Adam SMITH, já na Riqueza das Nações defendia a atuação do Estado nas atividades de interesse social que fossem deficitárias o que colocava o problema de definir qual o limite da intervenção do Estado na economia desde o liberalismo. Para uma resenha da questão no Estado Liberal consulte-se Jorge Reis NOVAIS (in Contributo para uma teoria do Estado de Direito - do Estado de Direito liberal ao Estado social e democrático de Direito, Coimbra: Coimbra, 1987, p. 55-56.)

${ }^{30}$ DI PIETRO, Maria Sylvia Zanella. Discricionariedade..., p. 21.

${ }^{31}$ Sobre a inter-relação desses valores e a necessidade de uma compreensão harmônica entre eles, anota Nuno PIÇARRA: "Para conhecer o sentido, o conteúdo e o alcance do princípio da separação dos poderes no Estado de Direito liberal há que analisar, o mais sinteticamente possível, os seus 'pontos de referência' ou 'referenciais' no quadro deste Estado ou, por outras palavras, os outros traços essenciais deste, que determinaram
} 
Haja vista a importância da legalidade e da separação de poderes para a afirmação do modelo liberal (e a sua incorporação ao conceito de Estado de Direito) é de se passar por esses temas apenas para lançar alguns pressupostos de trabalho a serem retomados adiante, ainda que sem pretensão de exaurir o assunto.

A separação de poderes $^{32}$ é resultado de uma longa evolução cultural e histórica (reconduzida às vezes até a Grécia Antiga), que encontra larga ressonância no sistema constitucional inglês (preocupado com o sensível equilíbrio entre Rei, nobreza e povo), sendo universalmente incorporada aos sistemas político-jurídicos ocidentais com a afirmação do Liberalismo.

O tema não se reveste de uma unidade de tratamento, sendo variáveis as soluções encontradas ao longo do tempo em diversos lugares; há tantas "separações de poderes" quanto Estados que busquem implementá-las. ${ }^{33-34}$ Mesmo a sua formulação teórica é disputada, tanto em relação à origem (v.g. o ineditismo ou não da formulação célebre de Montesquieu) quanto ao efetivo conteúdo do pensamento de cada autor ${ }^{35}$. Nada obstante esses percalços, é absolutamente necessário ferir o tema intimamente associado ao Liberalismo e a própria afirmação da função administrativa como categoria jurídica própria.

Dois núcleos fundamentais no sentido de proteção do indivíduo são derivados da separação de poderes de caráter Liberal. ${ }^{36-37-38} \mathrm{O}$ primeiro, de caráter eminentemente

dialeticamente a própria conformação do princípio, constituindo com ele uma unidade, no preciso sentido de relação intrínseca entre elementos não concebíveis uns sem os outros.” (A Separação..., p 145). Ou seja, não há uma demarcação absoluta - em especial entre legalidade e separação de poderes - conformando-se mutuamente os elementos do Estado Liberal, não sendo dado conhecê-los de modo estanque.

${ }^{32} \mathrm{O}$ tema é de tal modo vincado ao Direito Administrativo que Eduardo García de ENTERRÍA e Tomás-Ramón FERNÁNDEZ apontam ser esse ramo do direito produto dessa concepção - "Hemos puesto especial insistencia em subrayar la importancia del principio de división de poderes como marco em el que nasce y se desarrolla la Administración y el Derecho Administrativo contemporáneos" (Op. cit., p. 41). Demonstrando a força do dogma tem-se o art. 16 da Declaração dos Direitos do Homem, de 1789, que identifica Constituição e separação dos poderes: onde esta não houvesse, aquela não existiria.

33 "Tome-se em conta que não existe uma única teoria da separação de Poderes, compartilhada igualmente por todos os países. A teoria da separação de Poderes é adotada em quase todos os países, com configurações próprias e inconfundiveis." (Marçal JUSTEN FILHO. Curso de Direito Administrativo, São Paulo: Saraiva, 2005, p. 24.)

${ }^{34}$ Para uma crítica a concepção absoluta do princípio da separação dos poderes enquanto dogma, identificando o seu relativismo e a sua óbvia inspiração liberal consulte-se Karl LOEWENSTEIN. Teoria de la Constitución, 2. ed. Barcelona: Ariel, 1986, p. 55-57.

${ }^{35}$ Para uma suma da evolução histórica do princípio da separação dos poderes, analisando o seu conteúdo bem passando pela enunciação das controvérsias em relação ao pensamento dos diversos autores clássicos sobre o tema, consulte-se: Nuno PIÇARRA. Op. cit., passim.

${ }^{36}$ Cf. Nuno PICARRA, Ibidem, p. 143-153. O autor citado chega a sustentar a incompatibilidade das visões com estribo nos diferentes referenciais. Sustenta-se a incompatibilidade do modelo norte-americano fundado em uma 
organizativo, diz com o fato de que as tarefas do Estado devam ser exercidas por entes diversificados, de modo a que nenhum desses centros de atuação estatal (usualmente chamados de "Poderes") possa desbordar de seus limites, sem incidir em controle dos outros. Cria-se uma harmonia entre os diferentes centros decisórios, cada qual controlando os demais, sendo essa técnica chamada usualmente na doutrina de inspiração norte- americana de check and balances (freios e contrapesos).

O segundo, diz com a garantia da supremacia da lei como produto de uma vontade geral, sendo a separação de poderes chamada a garantir essa primazia do produto emanado do Parlamento, portador de uma vontade geral, vinculante dos particulares. A centralidade decisória é reconhecida ao Parlamento, que pela lei regula a vida social não podendo ser essa emanação contaminada quer pelos executores da lei, quer pelos julgadores (que devem aplicála mecanicamente). Neste sentido, torna-se sem tanta importância a idéia de equilíbrio recíproco, que pressupõe a multicidade de focos de ordenação da vida política para além do legislativo. A idéia de justeza da atuação estatal não está no equilíbrio de "poderes" e sim mesmo no conceito de lei, portador de um conceito próprio de justiça, incapaz de degenerar em arbítrio pela sua própria natureza. É pressuposto desta visão de supremacia do Parlamento uma avaliação monista, que identifica o Estado com o direito (no sistema de freios e contrapesos está, pelo contrário, implícita uma visão pluralista em que se privilegia o equilíbrio entre os diversos centros pelos quais se exprime a ação do Estado).

concepção organizativa tributária das idéias de constituição mista que implica em diferentes potências do jogo político se controlarem mutuamente, não podendo uma anular a outra com a visão tipicamente continental que prega a supremacia do Parlamento e a justeza da sua atuação, isto é a lei (bem entendida, lei liberal) com seus atributos de generalidade e abstração, como essência da garantia da separação dos poderes - "No Estado de Direito de legalidade (...) que se constitui para realizar o sentido que o iluminismo confere à lei, o princípio da separação dos poderes é exclusivamente chamado a garantir o primado da lei" (p. 149.)

${ }^{37}$ Neste sentido dual também se manifesta José Joaquim Gomes CANOTILHO. Direito Constitucional e Teoria da Constituição. 5. ed. Coimbra: Almedina, 2002, p. 250.

${ }^{38}$ Sobre o relativismo da noção de separação de poderes, e da efetiva existência de duas matrizes na prática, brilhante a passagem de Vasco Manuel Pascoal Dias Pereira da SILVA: "é curioso como a raiz comum do liberalismo político - a experiência político-constitucional inglesa - vai dar origem a duas experiências históricas radicalmente diferentes, que vão cristalizar nos sistemas administrativos 'de tipo britânico' $e$ 'de tipo francês'(...) Poder-se-ia dizer que tudo se passou como se de um 'jogo de espelhos' se tratasse, em que a reflexão da imagem, da experiência britânica para obra de MONTESQUIEU e da obra de MONTESQUIEU para a revolução americana primeiro, e a revolução francesa depois, leva à sua progressiva deformação $e$ afastamento do modelo original." (Op. cit,, p. 16-17) 
Na Europa continental e no sistema de direito romano-germânico prevaleceu, no período liberal, essa concepção de separação de poderes, intimamente associada à supremacia da lei e do parlamento como garantia suficiente do patrimônio individual. ${ }^{39}$

Ainda, agregou-se a isto a idéia (bem chamada de mito por Eros Roberto GRAU ${ }^{40} \mathrm{e}$ Clèmerson Merlin CLÈVE ${ }^{41}$ ) de que haveria um valor absoluto na propositura tripartida da Montesquieu em relação às funções do Estado e os entes encarregados de atuá-las. Embora haja certa divergência sobre o ponto, o esquema proposto por MONTESQUIEU não era um fim em si mesmo e respondia a questões historicamente bem definidas. O arranjo visava a garantir um equilíbrio entre as diversas forças atuantes na França àquele tempo, segundo o modelo de Constituição mista havido na Inglaterra, peculiar haja vista a ausência de uma concepção unitária de Estado ${ }^{42}$; e não propor uma doutrina absoluta e científica acerca do tema, a ser incorporada como verdade imutável. ${ }^{43} \mathrm{O}$ fato é que a implementação prática dos pressupostos teóricos, especialmente na França, fez com que ela fosse tomada de modo muito mais radical do que pretendeu seu fundador teórico mais próximo (que, aliás, era aristocrata); tal concepção informa o surgimento do contencioso administrativo. $\mathrm{O}$ exemplo é elucidativo na medida em que a criação que visava a garantir, com máximo vigor a tripartição de poderes o que vai mesmo contra o espírito original da noção e deixa a Administração carente de meios de controle efetivo ao lha atribuir um espaço por assim dizer, independente. ${ }^{44}$

Isto coloca, nesse momento, a necessidade de se analisar legalidade e separação dos poderes de modo conjugado. Pois, consoante se anotou acima, a legalidade e a separação de poderes se condicionam reciprocamente no sentido de garantir as liberdades pretendidas pelos cidadãos, não podendo ser compreendidas de modo divorciado. O sistema de garantias só se

\footnotetext{
${ }^{39}$ Essencialmente, essa foi a formulação que chegou ao direito brasileiro e não a versão americana dos freios e contrapesos, como anota Eros Roberto GRAU: "Sua doutrina [da separação dos poderes] chega até nós a partir da exposição de Montesquieu, e não pela via da postulação norte-americana dos freios e contrapesos." ( $O$ Direito Posto e o Direito Pressuposto, 5. ed. São Paulo: Malheiros, 2003, p. 226.)

${ }^{40}$ Ibidem, p. 225.

${ }^{41}$ CLÉVE, Clemerson Merlin. "De tal modo foi aceita a formulação de Montesquieu que deu origem a um mito: o mito da separação, decorrente do apego dogmático dos juristas a uma técnica de contenção do poder nascida num período determinado, e mais do que isso, para fazer face a questões desafiantes de um contexto determinado." (In Atividade Legislativa do Poder Executivo. 2. ed. São Paulo: RT, 2000, p. 24.)

${ }^{42}$ Neste sentido, anotam Eduardo García de ENTERRÍA e Tomás-Ramón FERNÁNDEZ que rei, Parlamento e juízes não se incorporavam a uma noção de Estado, no sentido continental, e sim de Constituição (Op. cit., p. 3236.)

${ }^{43}$ Sobre o tema consulte-se o capítulo referente ao pensamento de Montesquieu na obra de Nuno PIÇARRA que faz uma recolha das diversas leituras possíveis acerca do tema (Op. cit., p. 88-123).

${ }^{44}$ Neste sentido, Vasco Manuel Pascoal Dias Pereira da SILVA. Op. cit., p. 11-43.
} 
fecha em se atentando (ao lado da separação de poderes) ao conceito liberal de lei, que identifica essa categoria como a vontade geral expressa pelo Parlamento como regra de conduta a sujeitar a todos de igual maneira. Descortinando a íntima relação entre legalidade e separação dos poderes no paradigma liberal anota Maria Sylvia Zanella DI PIETRO: As duas idéias principais que servem de base para esse princípio [da legalidade] são, de um lado, a de que o único poder legítimo é o que resulta da vontade geral do povo, manifestada pela lei; acima dessa vontade nenhuma outra se coloca, nem mesmo a do monarca; de outro lado, a idéia de separação de poderes, que dá primazia ao Poder Legislativo, colocando os dois outros sob a égide da lei." ${ }^{45}$ A atuação administrativa, no que tange a interferir sobre os particulares cingia-se, pois, à mera execução da lei.

Em relação à idéia da supremacia da lei, decorre ela (remetendo a concepções liberais fundadas na idéia contratualista) do consenso social como força obrigatória, não podendo se reconhecer autoridade maior que a dessa instituição. A lei, produto da vontade geral, se impunha aos indivíduos por ser fruto do consentimento institucionalizado do corpo social, que se sujeitavam racionalmente a ela por reconhecerem neste um meio eficaz contra o arbítrio do Estado. A lei enquanto emanação dessa vontade geral era legitimada e continha em si as inspirações de uma ordem racional e perene. É, precisamente, por ser expressão da vontade geral, forjada pelos representantes da sociedade, que se legitima a lei como força ordenadora da sociedade. Na síntese de Jorge Reis NOVAIS:

Nesta concepção de lei, entendida não como comando configurador, mas como quadro formal de garantia das liberdades e da segurança da propriedade, o Estado de Direito liberal realizava-se como Estado de razão, como reino de leis, onde a cooperação da representação popular garantia a realização de uma justiça imanente ao livre encontro das autonomias individuais e o carácter geral e abstracto das leis assegurava a segurança e a prebvisibilidade requeridas pela auto-regulação do mercado. ${ }^{46}$

Mais ainda, o Estado fica adstrito à lei, não podendo ser considerado um sujeito externo à regulação jurídica (como fora o Rei no absolutismo). Toda atuação estatal passa a ser condicionada pela lei no que tange à articulação entre Estado e sociedade. Sobre o tema anota Carlos de Cabo MARTÍN:

\footnotetext{
${ }^{45}$ DI PIETRO, Maria Sylvia Zanella. Discricionariedade..., p. 22.

${ }^{46}$ NOVAIS, Jorge Reis. Op. cit., p. 89.
} 
Y este sometimiento de los poderes del Estado a la ley implica la regulación por parte de la ley de la relación (separación) Estado-sociedad, en cuanto, supone, por un lado, que el Estado actúa conforme a leyes (sub lege) y, por otro, a través de leyes (per legem), con o que se establecen las bases para la libertad e igualdad ciudadanas (...) la garantía de la desaparición del privilegio ante la abstracta equiparación de los sujetos de Derecho por la universalización de la ley. 47

Essa noção é reforçada pela idéia de que a lei é dotada de um conteúdo geral e abstrato, obrigando a todos de modo indistinto e não promovendo favorecimentos. Usualmente, apontase que o conteúdo da lei é genérico e abstrato, tendo sido essa uma contribuição institucionalizada pelo Estado Liberal. Embora seja a lei (por ser instrumento de veiculação de normas jurídicas) matéria prima de essência ao trabalho do jurista, é de se ver que o conceito evoca uma série de sentidos, não necessariamente coincidentes ${ }^{48}$, bem como ao longo da história a idéia de lei variou significativamente ${ }^{49}$. Como anota Tércio Sampaio FERRAZ

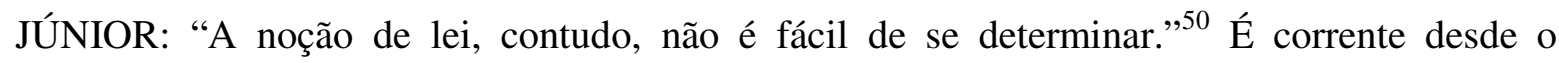
liberalismo, todavia, associar o conteúdo da lei com as notas de generalidade e abstração o que implica, basicamente, em duas dimensões (cf. José Joaquim Gomes CANOTILHO ${ }^{51}$ ). A uma, a lei implica uma deliberação não formulada à luz de uma situação concreta e sim alcança situações abstratas, regulando uma quantidade indeterminada de situações para o futuro nela abrangidas. A duas, que a lei se destina a toda a coletividade alcançada pelo preceito e não apenas a alguns indivíduos. Essas características, então, é que visam a garantir o conteúdo necessariamente justo da lei, ainda que haja a adoção de um conceito de lei formal pelo Liberalismo.

\footnotetext{
${ }^{47}$ MARTín, Carlos de Cabo. Sobre el concepto de ley. Madri: Trotta, 2000, p. 19.

${ }^{48}$ Sobre a variação da classificação das normas jurídicas (que se reflete na idéia de lei), anota Norberto BOBBIO: "Há distinções que se referem ao conteúdo das normas: por exemplo, aquela entre normas materiais e normas processuais, ou entre normas de comportamento e normas de organização. Outras distinções se referem ao modo em que as normas são estabelecidas, como aquela entre as normas consuetudinárias e as legislativas. Outras ainda, se referem aos destinatários, como aquela entre as normas primárias e as secundárias." (Teoria da Norma Jurídica, São Paulo: Edipro, 2001, p. 177-178.)

${ }^{49}$ Fazendo síntese da evolução da idéia de lei aponta José Joaquim Gomes CANOTILHO (Op. cit., p. 708- 709) a variação do seu conteúdo. Aponta o constitucionalista português que no pensamento antigo a idéia de lei era associada a um conteúdo geral de justiça e razão, sendo esse o sentido primordial do tema entre gregos e romanos. Posteriormente, lei foi identificada como vontade vinculante posta para uma coletividade (cf. o pensamento de HOBBES, v.g). A ascensão do liberalismo levou à identificação da lei como instrumento da liberdade individual, o que era garantido pelas suas notas de abstração e generalidade (LOCKE representa essa linha). Outros pensadores representantes do liberalismo apontaram outras notas acerca da idéia de lei. ROUSSEAU, ressalta a idéia de lei como produto da vontade geral. Montesquieu, associa lei à função legislativa de modo a garantir a tripartição do poder estatal.

${ }^{50}$ FERRAZ JÚNIOR, Tércio Sampaio. Introdução ao Estudo do Direito. 2. ed. São Paulo: Atlas, 1994, p. 232.

${ }^{51}$ CANOTILHO, José Joaquim Gomes. Op. cit., p. 709.
} 
Completando a idéia, da qual já se teve oportunidade de falar algo acima, tem-se que a esfera reservada tipicamente aos cidadãos era (desde um ponto de vista idealizado) alheia a qualquer sorte de ingerência do Estado que sobre elas não expedia comandos legais que restringissem um patrimônio que se julgava intangível. Os direitos individuais constituíam assim um limite ideal à ação legislativa do Estado.

A idéia é bem posta por Vasco Manuel Pascoal Dias Pereira da Silva

\begin{abstract}
Um dos fenómenos teorizados pela referida doutrina do Estado de Direito é o que diz respeito à lei. Lei essa entendida e teorizada no quadro do modelo liberal de Estado. Caracterizando, em traços largos, essa forma de relacionamento entre a sociedade e o poder, há que ter em conta que, de acordo com a concepção liberal, o problema da liberdade individual colocava-se, sobretudo, em face do Estado, sendo a não intervenção deste e a separação radical entre Estado e sociedade a melhor garantia da liberdade política. O Estado encontrava-se numa posição de superioridade, actuando através de lei geral e abstracta e não intervindo, ou intervindo o 'mínimo', na vida em sociedade. A sociedade era a sociedade burguesa, que se entendia estar representada no Parlamento, eleito por sufrágio censitário. A liberdade identificava-se com a liberdade da burguesia e era concebida em termos de estremas, como a propriedade ('a minha liberdade termina onde começa a liberdade do outro'); a solidariedade era vista como problema da sociedade e não do Estado, o qual devia se limitar a permitir que fosse a sociedade a segregar as suas próprias formas de solidariedade. ${ }^{52}$
\end{abstract}

O conceito liberal de lei e a separação dos poderes entendida como supremacia do Parlamento, ambos com os diversos temperamentos exigidos pela diversidade histórica e geográfica, são as colunas mestras da liberdade jurídica dos cidadãos em face do Estado, fundamentos desse paradigma. São as técnicas jurídicas que tem a preocupação mais imediata em salvaguardar a liberdade dos particulares, evitando e contendo o excesso do Estado, implementando desde o mundo do direito a ordem liberal. É o que destaca Eros Roberto GRAU:

A legalidade consubstancia extensão da teoria da soberania popular e da representação parlamentar. A Constituição contém a ação do Estado e a burguesia encontra, no quadro da separação dos poderes, condições adequadas à defesa de seus interesses econômicos; qualquer 'atentado' à liberdade econômica e à propriedade somente poderia ser consumado com o consenso dos representantes da burguesia, isto é, através de uma lei. A legalidade assume desde logo sua dupla face, como supremacia e reserva de lei. (...) Desnuda-se, destarte, o sentido eminentemente liberal do princípio, até nossos dias preservado, na medida em que a doutrina reitera ser ele dotado do sentido de impedir que o Executivo possa estabelecer, por ato seu, restrições à liberdade e à propriedade dos indivíduos e que a razão mesmo do Estado de Direito é a defesa do indivíduo contra o Poder Público; e que a fórmula, por excelência, asseguradora desse desiderato descansa na tripartição do exercício do poder. Ignora-se inteiramente que o Estado moderno não é apenas titular jus imperii, mas também agente do fornecimento de prestações aos particulares. ${ }^{53}$

\footnotetext{
${ }^{52}$ SILVA, Vasco Manuel Pascoal Dias Pereira da. Op. cit., p. 48.

${ }^{53}$ GRAU, Eros Roberto. Direito..., p. 172-173.
} 
Diante desse referencial teórico relativo à lei e à separação dos poderes é que vai ser concebida a atuação da Administração no Estado Liberal como submetida a um princípio de legalidade, especialmente no que toca às relações com os particulares. ${ }^{54}$ Embora no início tenha se relutado em afirmar a vinculação positiva da Administração à lei (superando a mera vinculação negativa do direito comum), com o tempo, passou a prevalecer que a lei era o justo título que autorizava a atuação da função executiva, que nada mais fazia que operar comandos gerais e abstratos impostos por lei. ${ }^{55}$

Todavia, desde o ponto da relação com a esfera dos particulares, dúvida não havia, em se adotando os pressupostos liberais, de que as relações da Administração estavam inexoravelmente submetidas à legalidade, não podendo ela atuar potência alguma que não tivesse sido vertida em lei, enquanto expressão da vontade geral, forjada no Parlamento.

Dessa concepção de legalidade, informada por todas essas contingências políticojurídico-culturais, é que se pode inferir o modelo de função administrativa existente à época.

A função administrativa no modelo liberal é tributária dos elementos vistos acima, em especial, da separação dos poderes e da legalidade (como pressupostos da garantia da liberdade individual).

Em um paradigma liberal, a primeira nota a ser assinalada é o caráter mínimo do direito administrativo, associado apenas às matérias que visavam a garantir a boa ordem para a atuação livre dos particulares. ${ }^{56}$

\footnotetext{
${ }^{54}$ Diz-se, essencialmente, pois houve na Alemanha forte movimento tendente a advogar a tese de que aquilo que não dissesse respeito à relação Estado/indivíduo ou indivíduo/indivíduo e, portanto, fosse afeito à esfera interna da Administração seria passível de regulação por atos expedidos por ela diretamente, e não provenientes do Parlamento. Tal visão, creditada a Laband, parte de um conceito material de lei e tinha por mote específico explicar na Alemanha certas prerrogativas da monarquia articulando o princípio monárquico com o princípio representativo. Para uma resenha dessa questão consulte-se Carlos de Cabo MARTÍN (Op. cit., p. 35-47.) É esta concepção, que nega juridicidade à dinâmica das relações internas da Administração, que explica criações tipicamente alemãs como a sujeição específica e o regulamento administrativo (cf. Vasco Manuel Pascoal Dias Pereira da SILVA, Op. cit., p. 59-60. Neste mesmo sentido manifesta-se Maria Sylvia Zanella DI PIETRO, que aponta que o Estado Liberal impunha uma vinculação negativa à Administração (in Discricionariedade..., p. 2628.)

55 Sobre o tema legalidade no Estado de Direito consulte-se, Maria Sylvia Zanella DI PIETRO, Ibidem, p. 26-28. Ainda, é de se indicar a obra de Jorge Reis NOVAIS, Op. cit., p. 90-100, na qual se demonstra a passagem do Estado Liberal por três estágios no que toca à legalidade: prevalência da lei em que a lei era limite à atuação da Administração; reserva parcial da lei, em que a lei necessariamente era fundamento de validade sobre atuações públicas sobre a liberdade e a propriedade e, por fim, a reserva total da lei, impondo esse veículo como caracterizador de todas as atuações da Administração.

${ }^{56}$ Alberto VENÂNCIO FILHO, citando Adam SMITH, diz que àquele tempo eram reservadas aos Estados as seguintes tarefas: dever de proteção da sociedade contra ameaças externas, proteger os seus membros da opressão de qualquer outro cidadãos, o dever de erigir certas obras públicas e explorar certas atividades que não eram de
} 
Sobre o tema manifestam-se Pedro GONÇALVES e Licínio Lopes MARTINS:

\begin{abstract}
No plano da intervenção de natureza administrativa, competia-lhe fundamentalmente garantir a segurança interna e externa, assegurar a convivência pacífica entre os cidadãos, manter a ordem pública, Mas mesmo nestes domínios, a intervenção pública teria que ser comedida - a prossecução daqueles fins públicos deveria limitar o menos possível a liberdade dos indivíduos. Do ponto de vista da intervenção administrativa, ao Estado liberal cabia portanto uma função estritamente executiva da lei: os actos administrativos de autorizar, de proibir, de limitar, de fiscalizar e de liquidar e cobrar impostos, na estrita execução da lei, eram seus actos típicos. ${ }^{57}$
\end{abstract}

Não havia quaisquer fins a serem promovidos senão a garantia da paz social aos particulares, o que não exigiam grandes missões institucionais a cargo do Estado, pois, toda responsabilidade referente ao progresso social estava a cargo dos particulares. Sinteticamente, cabia à Administração assegurar que o exercício individual da liberdade de um cidadão não perturbasse a esfera de outro, dentro dessas traves, o resultado das ações privadas era indiferente.

Mais ainda, a atividade administrativa era vista como necessariamente invasiva e devia circunscrever-se a um mínimo a ser tolerado, estritamente na medida do bem comum, do interesse público. ${ }^{58} \mathrm{O}$ conceito predominante à época é de o exercício da função administrativa ser por si só intrusivo, devendo estar contido ao máximo. Às formulações jurídicas que pautavam o exercício da função administrativa competia formalizar esse paradigma de intervenção mínima.

Malgrado essa nota de intrusividade (inerente a uma concepção individualista), e aí o grande paradoxo do direito administrativo vigente à época, o Direito Administrativo do Estado Liberal se estrutura a partir de meios absolutamente consagradores de autoridade, ainda derivados das noções autoritárias anteriores ao Estado de Direito. ${ }^{59}$

Ou seja, há no Direito Administrativo do período liberal uma forte nota de autoridade, especialmente quanto à organização da Administração, que ainda é eco do regime do Estado de Polícia. Embora haja compromisso com as liberdades dos cidadãos a atuação da

interesse dos particulares, mas aproveitavam à coletividade (in A Intervenção do Estado no Domínio Econômico - O Direito Público Econômico no Brasil, edição fac-similar da de 1968, Rio de Janeiro: Renovar, 1998, p. 4-5.)

${ }^{57}$ GONÇALVES, Pedro; MARTINS, Licínio Lopes Os Serviços Públicos Económicos e a Concessão no Estado Regulador. MOREIRA, Vital (org.) Estudos de Regulação Pública. Coimbra: Coimbra, 2004, v. 1. p. 174.

58 Sobre o tema consulte-se a importância desses títulos legitimadores da atuação estatal, quer no plano legislativo quer no plano executivo em Floriano Peixoto de Azevedo MARQUES NETO, Op. cit., p. 23-99.

${ }^{59}$ Associada a idéia liberal de que a actividade administrativa deveria ser reduzida ao mínimo, andava o entendimento da Administração como realidade agressiva dos direitos dos particulares, actuando atavés de meios autoritários.” Vasco Manuel Pascoal Dias Pereira da SILVA (Op. cit., 61-62.) 
Administração não deixa de ser agressiva e fundada em elementos de pura autoridade, herdados da organização administrativa anterior. ${ }^{60}$ Havia, por certo, ainda um compromisso com a autoridade necessária ao desenvolvimento do ideário liberal. Nesse sentido, analisando esse caráter dúplice do Direito Administrativo, anota Maria Sylvia Zanella DI PIETRO: "Desde o princípio, o direito administrativo caracterizou-se pelo duplo aspecto, de um lado voltado para manutenção da autoridade do poder público e, de outro, para o respeito das liberdades dos cidadãos.",61

Didaticamente, o Estado Liberal atuava de forma mínima, mas quando o fazia não se furtava de se valer de prerrogativas de autoridade, sendo a organização administrativa orientada para possibilitar esse paradigma autoritário. A autoridade voltava-se para a manutenção da ordem liberal, especialmente garantindo o seu suporte econômico (i.e. garantindo a intangibilidade da propriedade e do contrato) contra qualquer turbação.

A noção da atividade administrativa neste período era explicada pela idéia geral de um poder de polícia (derivado ainda do Estado Absoluto ${ }^{62}$, não à toa, chamado "de Polícia") que servia de categoria que dotava de racionalidade o exercício da função executiva.

Há clara identidade em relação ao poder de polícia e às missões que eram reservadas à Administração no Estado Liberal. ${ }^{63}$

\footnotetext{
${ }^{60}$ Sobre o tema anota Vasco Manuel Pascoal Dias Pereira da SILVA: "O modelo de Administração Pública surgido com o Estado liberal pode ser, em traços gerais, caracterizado: no que respeita às formas de actuação, por fazer do acto administrativo o seu modo quase exclusivo de agir; quanto à organização administrativa, por apresentar uma estrutura concentrada e centralizada (...) numa Administração concebida como agressiva dos particulares, o fulcro da actividade administrativa residia no acto administrativo, entendido como manifestação de autoridade. (...) O acto administrativo vai, então, procurar conciliar uma vertente autoritária, de exercício de um poder do Estado, com uma vertente de garantia dos cidadãos, decorrente do princípio da legalidade, reproduzindo assim, a este nível, aquele compromisso que estava subjacente ao conceito liberal de Estado. (...) A organização administrativa do Estado liberal pode ser caracterizada pela concentração e centralização (...) $O$ Estado liberal vai herdar de seu antecessor, o Estado absoluto, a organização centralizada do poder." (Ibidem, p. 40-41.)

${ }^{61}$ DI PIETRO, Maria Sylvia Zanella. In Discricionariedade..., p. 25.

${ }^{62}$ Neste sentido, Agustín GORDILLO. Tratado de Derecho Administrativo, Tomo 1. 7. ed., Belo Horizonte: Del Rey, 2003, p. II, 6.

${ }^{63} \mathrm{Na}$ doutrina, há em relação ao conceito estrito de poder de polícia (que exclui a idéia de atividade normativa) um núcleo que associa ação da Administração/restrição à liberdade e à propriedade (direitos tipicamente liberais)/em prol do bem comum, bem estar geral, ou outro título dessa ordem. Neste sentido, é que se demonstra ser o Poder de Polícia a categoria unificadora da função administrativa no período liberal, podendo ser o grosso de suas atividades reconduzidas a essa noção. Dentre nós, até hoje, o poder de polícia é invocado como fundamento das atuações administrativas sobre a liberdade e a propriedade ( $v . g$. em matéria de intervenção na propriedade), mantendo-se um certo caráter "agressivo", de tônus liberal. Para uma crítica ao poder de polícia concebido nesses termos consulte-se Carlos Ari SUNDFELD. Direito Administrativo Ordenador, São Paulo: Malheiros, 2003.
} 
Na síntese de Caio TÁCITO anota acerca do poder de polícia liberal: "O poder de polícia consiste, em suma, na ação da autoridade estatal para fazer cumprir o dever de não perturbar a boa ordem da coisa pública. É em torno à noção desse dever geral de respeito à ordem coletiva que repousa toda construção teórica da faculdade do Estado de regular a atividade individual". 64

A categoria fundamental que traduzia o exercício da função administrativa era o ato administrativo que trazia em sua essência uma nota de autoridade, que lhe particularizava em relação aos atos privados (fundados na noção consensual de negócio jurídico). ${ }^{65}$

O universo do ato administrativo unilateral e dotado de carga de executividade é sem dúvida a noção mais importante da atuação da Administração nesse período, sendo muito tímido o espaço relegado a outras manifestações. É sobre o influxo da categoria ato administrativo que se explica como age a Administração no Estado Liberal.

Não por outra razão, o Direito Administrativo é visto como um direito exorbitante do direito comum, na medida em que nele se consagram privilégios estranhos ao mundo dos privados. ${ }^{66}$ Privilégios estes que constituem cargas de autoridade incapazes de habitarem o mundo das relações privadas.

Do que se viu então, pode-se fazer a síntese de como deve ser concebida a noção de função administrativa sob as pautas do Estado Liberal.

Função administrativa no Estado Liberal consistia no exercício pela Administração de competências definidas, necessariamente, em lei que visavam a possibilitar a livre atuação dos interesses individuais. O escopo maior da missão reservada ao Estado Administração era garantir a satisfação dos direitos liberais inerentes à personalidade por meio da restrição a quaisquer excessos - tanto do Poder Público quanto dos particulares - cometidos.

\footnotetext{
${ }^{64}$ TÁCITO, Caio. O Poder de Polícia e seus limites, in Temas de Direito Público, v. 1. Rio de Janeiro: Renovar, 1997, p. 522.

${ }^{65}$ Neste sentido, consulte-se Vasco Manuel Pascoal Dias Pereira da SILVA. Op. cit., p. 43-71.

${ }^{66} \mathrm{O}$ conceito de ser o Direito Administrativo um ramo dotado de especialidade, sendo direito exorbitante do direito comum não surge no Estado Liberal, sendo comum já ao período absoluto, sendo corrente a formulação de que o direito do Príncipe exorbitant a jure commune. Aliás, indicam Eduardo García de ENTERRÍA e TomásRamón FERNÁNDEZ texto de 1442 na Espanha que se vale do conceito de exorbitância para caracterizar a atuação administrativa (in Curso..., p. 30-31.) Cumpre assinalar que até hoje a idéia se faz presente no direito administrativo brasileiro como se vê no conceito encerrado nas "cláusulas exorbitantes" que peculiarizam os contratos tipicamente administrativos.
} 
A categoria unificadora da atuação administrativa era o ato administrativo (sob seu viés autoritário) e a grande categoria que visava a dar sustentação teórica ao modelo era o poder de polícia, entendido no seu sentido mais corrente.

\title{
1.2. ESTADO SOCIAL E CARACTERIZAÇÃO DA FUNÇÃO ADMINISTRATIVA
}

São conhecidas as razões que levam à derrocada do Estado Liberal e à afirmação de um novo modelo em seu lugar, mais capaz de dar satisfação às promessas não cumpridas daquele período. Fundamentalmente, o Estado Liberal não conseguiu, por meio do livre jogo das forças privadas, dar resposta satisfatória ao que tinha se proposto, passando a exigir-se uma alteração radical das missões reservadas ao Poder Público. A liberdade havia degenerado em dominação e em degradação humana. ${ }^{67-68} \mathrm{~A}$ igualdade formal foi incapaz de gerar igualdade material. ${ }^{69}$ Como anota Maria Sylvia Zanella DI PIETRO:

\begin{abstract}
Já em meados do século XIX começaram as reações contra o Estado liberal. A abstenção do Estado acabou por gerar conseqüências funestas no âmbito econômico e social; as grandes empresas vão transformando-se em grandes monopólios e aniquilando as de pequeno porte; surge uma nova classe social - o proletariado - em condições de miséria, doença, ignorância, que tende-se a acentuar-se com o
\end{abstract}

\footnotetext{
${ }^{67}$ Para uma visão crítica da superação do Liberalismo é fundamental a referência a Eros Roberto GRAU que tece sua crítica desde o ideário burguês de liberdade, igualdade e fraternidade. Em um primeiro momento é de se assinalar que a liberdade econômica deu ensejo ao surgimento do poder econômico, sendo sua manifestação mais evidente a supressão da concorrência, impondo ao Estado o dever de atuar para garantir a existência do mercado, capaz de ser anulado por agentes que nele atuavam. A igualdade, limitava-se à dos porcos de Orwell, não sendo dotada de conteúdo efetivo, possuindo mero caráter formal. Somente tinham acesso às benesses do sistema aqueles que possuíam recursos para tanto. Por fim, a fraternidade não poderia ser institucionalizada em um ambiente onde o egoísmo e a competição são o padrão desejado de conduta (A Ordem Econômica na Constituição de 1988. São Paulo: Malheiros, 2004, p. 17-21.)

${ }^{68}$ Interessante, para contextualizar a real magnitude da degradação humana tolerada pelo liberalismo, trazer exemplo trazido por Antônio José Avelãs NUNES, citando comentário de um membro da Câmara dos Pares francesa, em 04/03/1840: "Se um tirano, um conquistador estrangeiro, tivesse ocupado a França e nos tivesse falado desse modo: logo que consigam manter-se sobre as pernas, centenas de milhares de vossas crianças servos-ão retiradas, introduzidas em estabelecimentos onde sua organização física será degradada, enfraquecida de ano a ano, onde, em vez de conhecerem as brincadeiras, a alegria, a liberdade da sua idade, serão iniciadas em tudo que há de mais deplorável na depravação humana, onde serão primeiro moralmente e depois intelectualmente embrutecidas, para serem em seguida fisicamente debilitadas, onde as vossas filhinhas perderão a inocência antes mesmo da idade núbil, se um tirano - dizia eu - tivesse agido assim com a França, não haveria ódio e injúrias suficientes para lançar sobre a sua cabeça. Pois bem! o juízo da indústria é esse." (Op. cit., p. 135-136)

${ }^{69}$ Neste sentido, Alberto VENÂNCIO FILHO, amparado em lição de Georges BOURDEAU, anota que uma das transformações do Estado Social foi a consideração de um homem concreto, considerado em suas relações e não meramente abstrato (Op. cit., p. 9).
} 
não intervencionismo estatal. Os princípios do liberalismo, voltados para a proteção da liberdade e igualdade, mostram-se insuficientes para debelar a profunda desigualdade que geraram. ${ }^{70}$

Neste sentido, o papel de um Estado meramente comprometido com a garantia da ampla atuação dos particulares, sem imiscuir-se diretamente com a promoção de valores sociais é posto em xeque; exigindo-se, gradualmente, ${ }^{71}$ uma atuação concreta no sentido da promoção do bem estar social. É na promoção dessa mudança de orientação, relegando-se o absenteísmo em favor do intervencionismo, que reside a afirmação história do Estado Social, como resposta à situação havida do ponto de vista social e econômico ${ }^{72}$.

Justamente, é característica marcante desse período, a substituição do modo de atuação do Estado que passa não mais apenas a buscar garantir as posições individuais, mas também logra buscar implementar valores, transformando a sociedade. Opera-se a superação de um papel de mero garante (sendo de se destacar que há um incremento das funções tradicionais) do Estado que assume, de forma ampla, o papel de prestador, provedor, das demandas sociais,

\footnotetext{
${ }^{70}$ DI PIETRO, Maria Sylvia Zanella. In Discricionariedade..., p. 28.

${ }^{71}$ Vasco Manuel Pascoal Dias Pereira da SILVA, anota os diferentes estágios havidos até a afirmação do Estado social. São três as etapas percorridas: ( $1^{\mathrm{a}}$ fase, intervenção nas relações de trabalho) um dos fracassos evidentes do Estado Liberal era a desigualdade das relações de trabalho em que os trabalhadores eram submetidos a condições verdadeiramente degradantes em nome de sua igualdade, passando o Estado a legislar sobre o tema impondo regras mínimas a serem seguidas (jornadas limitadas, limites de idade para o trabalho infantil, seguros, etc.); ( $\mathrm{a}^{\mathrm{a}}$ fase, intervenção generalizada na economia) decorrente dos esforços de direção havidos por conta da $1^{\mathrm{a}}$ Guerra, o estado ensaia o planejamento econômico e passa mesmo a produzir de modo direto bens e serviços; $\left(3^{\mathrm{a}}\right.$ fase, apogeu do Estado Social) a partir do fim da $2^{\mathrm{a}}$ Guerra o Estado assume amplamente o papel de ator maior da economia atuando nas mais diversas áreas, configurando-se o apogeu do período. (Op. cit., p. 72-73). O período mais radical é o das nacionalizações, valendo citar o preâmbulo da Constituição Francesa de 1946 que dispunha "todo bem, toda empresa cuja exploração tem ou adquire as características de um serviço público nacional ou de um monopólio de fato deve tornar-se propriedade da coletividade" (citado por Alberto Venâncio Filho. Op. cit., p. 13.) Para uma análise mais detida da história da intervenção do Estado na economia no período social, consulte-se André de LAUBADÈRE. Direito Público Económico, Coimbra: Almedina, 1985, p. 35-62.

${ }^{72}$ O Estado Social surge também como resposta a problemas inerentes do capitalismo como a existência de monopólios e a intenção de se evitarem crises neste modelo, nesse sentido assume também o papel de empresário. Desde o ponto de vista econômico, o Estado assume a posição de empresário, emergindo o modelo identificado por Antônio José Avelãs NUNES como capitalismo monopolista de Estado, em detrimento chamado de capitalismo monopolista. Sobre o tema anota o referido autor: "É que o Estado saiu de sua tradicional esfera política de actuação, despiu o manto que procurava apresentá-lo como instituição que nada tinha a ver com 'negócios' dos homens e invadiu às claras a esfera econômica. 'Estado económico' lhe chamou um autor para tornar bem claro que o estado é hoje um operador económico de primacial importância nas economias capitalistas: ele é muitas vezes o maior produtor, o maior investidor, o maior consumidor, o agente que movimenta a parte mais importante do rendimento nacional. De algum modo, a própria política é hoje - e cada vez mais - política econômica. E é este novo estatuto da função do estado no seio do capitalismo que a designação em análise permite relevar - capitalismo monopolista de estado." (In Os sistemas..., p. 178.)
} 
assumindo para si o compromisso da implementação do bem comum, atuando diretamente na economia. $^{73}$

Rompe-se, então, com a idéia do liberalismo de que a gestão privada dos assuntos econômicos teria o condão de promover o bem comum (neutralidade do agir estatal), cabendo ao Estado, apenas, permitir o livre agir dos atores sociais. Tais circunstâncias, obviamente, conduzem a uma radical modificação dos modos de atuar do direito administrativo. Como anota Maria João ESTORNINHO:

\begin{abstract}
Neste período do Estado Social, os fins do Estado colocados a cargo da Administração Pública estão essencialmente relacionados com as necessidades coletivas de segurança, de bem estar económico e social e de cultura. (...) Por outro lado, esse caráter mais activo e interventor da Administração Pública é indissociável do seu recurso a novos métodos de actuação. Na verdade, esta actuação intervencionista do Estado nem sempre é exeqüível através da organização burocrática tradicional da Administração Pública, pelo que esta precisa de recorrer a novos modelos de organização e de actuação mais flexível e dinâmicos." 74
\end{abstract}

À radical alteração do papel do Estado, corresponde uma verdadeira revolução nas estruturas havidas para desempenho das funções estatais. Cumpre então buscar compreender o fenômeno que pela primeira vez põe em causa as categorias gestadas à luz do ideário liberal.

Em breve síntese são os aspectos gerais do modelo do Estado Social conforme anota Luís S. Cabral de MONCADA ${ }^{75}$ : (i) perda da distinção liberal entre ordem pública e privada, passando o Estado a agir sobre os mais diversos domínios, o que leva à uniformização dos instrumentos de atuação pertinentes a estes dois ramos; (ii) alteração do papel reconhecido às normas jurídicas, no Estado social, as normas deixam de ser portadoras de idéias de neutralidade, assumindo conteúdos valorativos específicos que as identificam como programas de realizações e não como modelos atemporais e racionais de conduta; novo entendimento do Estado de Direito, não mais se identificando o conceito com aspectos formais de garantia e sim com a implementação de valores sociais e econômicos; (iii) A economia, essencialmente, deixa de ser um aspecto neutro em relação aos seus rumos, pois, o Estado passa a se comprometer com a implementação de certos modelos e valores sendo a noção de Estado de

\footnotetext{
${ }^{73}$ Apenas para ilustrar o quadro, ao qual o Brasil não ficou indiferente, menciona Caio TÁCITO o aumento da estrutura da Administração: "Até 1930 os órgãos paraestatais não iam além de 17, elevando-se a 70 nos anos 50 para atingir a cifra de 582 no início da década de 80" (Transformações do Direito Administrativo, in Temas de Direito Público. v. 3, Rio de Janeiro: Renovar, 2002, p. 13.)

${ }^{74}$ ESTORNINHO, Maria João. Op. cit., p. 37-39.

${ }^{75}$ MONCADA, Luís S. Cabral de. Op. cit., p. 25-39.
} 
Direito profundamente alterada por conta da intervenção estatal na economia e (iv) a intervenção estatal visa não a suplantar a racionalidade econômica de mercado e sim corrigir as suas falhas de modo a permitir sua regular atuação (combatendo monopólios e evitando crises cíclicas, o objeto da intervenção é "remover os obstáculos institucionais ao livre desenrolar daquela racionalidade de 'mercado' e criar as condições para que ela se exerça sem peias e entraves por justamente a considerar a mais adequada à atividade econômica e por reputar negativamente os desvios ao funcionamento respectivo." ${ }^{, 76}$ ).

Do mero cotejo entre as características usuais do período liberal com as evidenciadas no modelo de Estado Social pode-se ver as profundas distinções havidas entre ambos, a influenciar de modo severo o conteúdo da função administrativa. As categorias mais elementares do Estado Liberal são postas à prova pela emergência do Estado Social, implicando profundas alterações no modelo de Direito Administrativo havido, e no direito como um todo.

É da ausência de delimitação entre público e privado, tão cara ao Liberalismo que surgem grandes transformações sobre a disciplina dos institutos fundamentais do direito privado. Antes, o campo reservado à atuação livre dos particulares, orientado em torno das categorias do direito de propriedade privada (gerador de riqueza por excelência, verdadeira potência a ser posta em marcha pela vontade autônoma) e do contrato (móvel que permite a circulação de riqueza, transformando a potência do proprietário em ato ${ }^{77}$, era salvaguardado da atuação legal do Estado. O advento do Estado Social conduz à afirmação da função social da propriedade ${ }^{78}$ e põe peias à liberdade contratual, alterando profundamente o mundo das relações privadas.

O modelo do Estado Social passa a impor uma série de obrigações em relação ao exercício da autonomia da vontade, condicionando seu exercício ao atendimento de valores (por exemplo, determinando certos conteúdos em relação ao contrato). Neste sentido é que se

\footnotetext{
${ }^{76}$ Ibidem, p. 30.

${ }^{77}$ Neste sentido Eros Roberto GRAU (in A Ordem ..., p. 85-86.)

${ }^{78}$ Sobre o tema consulte-se artigo clássico de Fábio Konder COMPARATO, que anota: "Quando se fala em função social da propriedade não se indicam as restrições ao uso e gozo dos bens próprios. Estas últimas são limites negativos aos direitos do proprietário. Mas a noção de função, no sentido em que é empregado o termo nesta matéria, significa um poder, mas especificamente, o poder de dar ao objeto da propriedade destino determinando, de vinculá-lo a certo objetivo. $O$ adjetivo social mostra que esse objetivo corresponde ao interesse coletivo e não ao interesse do próprio dominus; o que não significa que não possa haver harmonização entre um e outro (...) A norma tem, indubitavelmente, o sentido de uma imposição de deveres positivos ao proprietário." (In Função social da propriedade dos bens de produção, Revista de Direito Mercantil - RDM 63/75.)
} 
alude à própria funcionalização das posições dos particulares. Mais ainda, sendo a ordem econômica um espaço de conflito (em especial, entre aqueles que detém os meios de produção e os que alienam a sua força de trabalho), não mais se relega aos particulares sua composição por meio do encontro de vontades. Passa o Estado a mediar e coordenar esses conflitos e o faz por meio do direito. ${ }^{79}$

Desde o ponto de vista da função administrativa, é de se ver que há o seu absoluto incremento sendo que a Administração deixa de apenas executar a lei e passa mesmo a integrar os comandos volitivos que obrigam os cidadãos. A Administração se torna a protagonista da regulação da vida social, como reflexo direto da gestão das missões prestacionais assumidas por si. Há um decréscimo da função dos Parlamentos em favor da ampliação do espaço da Administração.

Ao lado disso, assiste-se o aumento das estruturas administrativas sendo criada uma série de entes vinculados ao Estado que desempenham as mais diversas tarefas, contrapondose ao aspecto monolítico e centralizado da concepção liberal de Administração. Como anota Jean RIVERO, aumenta o volume da carga usualmente reconhecida à Administração, bem como surgem novas demandas a serem compostas. Explica o autor: "Mais decisiva ainda de que extensão das tarefas tradicionais é o aparecimento de tarefas inteiramente novas: é todo o desenvolvimento dos serviços econômicos e sociais." ${ }^{\prime 80}$

Assim, o direito administrativo passa a incorporar, ao lado de sua matriz clássica de organização do poder e de respeito ao administrado, cogitações acerca dos direitos sociais, concebendo-se uma série de institutos afeitos à oferta de utilidades aos administrados, bem como promover uma estrutura apta para tanto. O patrimônio dos cidadãos é acrescido de direitos que exigem, não a abstenção do Estado, mas a sua participação efetiva (v.g. direitos sociais), ${ }^{81}$ o que leva a uma mudança de perspectiva em relação à noção de administração do Estado Liberal.

\footnotetext{
79 “(...) o direito intervém no sentido de conformar e condicionar o exercício da vontade privada em ordem a interesses que assume em nome dos princípios da solidariedade social (...) O modelo jurídico do estado intervencionista atribui-lhe o papel de árbitro dos interesses em presença do terreno económico e social." (Luís S. Cabral de MONCADA. Op. cit., p. 26-27.)

${ }^{80}$ RIVERO, Jean. Direito Administrativo. Coimbra: Almedina, 1981, p. 32.

${ }^{81}$ Neste sentido consulte-se Clèmerson Merlin CLÈVE. Op. cit, p. 37.
} 
Como visto, a Administração nos moldes liberais era vista como agressiva, potencialmente violadora dos direitos dos cidadãos, a ser contida a domínios estritamente necessários para garantir o exercício da liberdade pelos cidadãos.

O esfacelamento da divisão público/privado, característica desse período, altera de modo fundamental a relação entre a Administração e o administrado, implicando em severas transformações. Surge um quadro de dependência do cidadão da Administração o que impõe a necessidade de alterar de modo substancial o conteúdo da relação administrativa. Chega mesmo a aludir-se a uma alteração psicológica em relação à Administração por parte do cidadão, no sentido de cada vez mais eles esperarem a atuação do Estado, dando conta do novo e profundo plano de inter-relacionamento dentre eles, incapaz de ser reconduzido ao eixo metodológico da divisão público/privado. ${ }^{82}$

A função administrativa, então, passa a ter que dar conta desse novo nível de relacionamento, incapaz de ser totalmente explicado pela lógica Liberal, em que o cidadão é dependente da Administração. A inter-relação entre Administração e administrado começa a ser não mais episódica (pontual) e sim duradoura, o que importa na necessidade de re-valorar o arcabouço jurídico que reveste essa vinculação entre ambos, concebendo instrumentos capazes de dar conta disto.

Mais ainda. Nessas pautas a idéia de separação dos poderes estanque, verdadeiro mito do liberalismo, sofre severos ataques. Primeiramente, é óbvio que diante de uma Administração a quem cumpre satisfazer às necessidades mais variadas da sociedade deve se reconhecer uma capacidade de atuação mais ampla da que a concebida no Liberalismo em que não se cogitava de tantos objetivos a serem satisfeitos. Desde este vértice, a Administração passa a ocupar a ribalta da cena política, em detrimento do velho Parlamento. Em um estado prestador, a Administração tem ampliada sua atuação, haja vista as demandas sociais que se lhe apresentam. ${ }^{83}$ Como leciona Karl LOWENSTEIN: "En la sociedad estatal del siglo XX, se

\footnotetext{
${ }^{82}$ Manifesta-se sobre essa alteração Jean RIVERO, nos seguintes termos: "Esta evolução repercute-se no domínio psicológico: desapontado pela experiência da liberdade, o homem reclama do Estado uma maior protecção e a salvaguarda da sua segurança." (Op. cit., p. 31.)

${ }^{83}$ Neste exato sentido, analisando a questão desde o prisma da separação dos poderes, Clèmerson Merlin CLÈVE se posiciona no seguinte sentido - "[O Estado Social] É um Estado de serviços. Por esse motivo, dos três poderes, o Executivo é aquele que tem ampliada sua atuação." (Op. cit., p. 41.)
} 
puede considerar como el fenómeno más digno de ser resaltado la transformación la transformación del Estado legislativo en el Estado administrativo". ${ }^{84}$

Outra transformação, esta mais sensível, diz com a impossibilidade de se reconhecer que a Administração é uma mera executora da lei. A Administração passa a ter que desempenhar a missão do progresso social sendo-lhes impostas tarefas bastante variadas, além daquelas concebidas à luz do paradigma anterior. Sobre o tema, como de estilo, preciso é Vasco Manuel Pascoal Dias Pereira da SILVA:

\begin{abstract}
Com a passagem do Estado liberal ao social, a administração pública deixa de ser concebida como meramente executiva (o que era, aliás, como vimos, mais um paradigma teórico que uma realidade efectiva), para se torna cada vez mais numa actividade prestadora e constitutiva. A administração prestadora chamou a si um conjunto de tarefas que não se esgotam na noção de aplicação da lei ao caso concreto, ou de execução do direito, mas que implicam a idéia de uma capacidade autónoma de concretização dos objectivos estaduais. ${ }^{85}$
\end{abstract}

Além da primazia entre as funções do Estado estar focada no Executivo, a própria noção da tarefa a ser por ele desempenhada muda. Neste quadro, a rigidez liberal emprestada à separação dos poderes fica obscurecida, tornando-se inviável separar com absoluto rigor qual função compete a cada Poder.

Desde o plano fático, a Administração começa a agir cada vez mais diante de uma lógica própria, comprometendo os ideais mesmo da lei no período liberal. A lógica adotada no liberalismo passa a não mais dar conta (como antes fizera) de explicar a relação havida entre as diferentes funções a serem atuadas pelo Estado, sendo incapaz de dar uma explicação uniforme aos fenômenos evidenciados como, por exemplo, a formulação de políticas públicas. ${ }^{86}$ A tônica é a hipertrofia do Executivo, curador máximo das demandas sociais, em correspondência de uma, diretamente proporcional, debilidade do Legislativo.

Reflexo imediato dessa alteração no plano da distribuição das tarefas estatais entre os seus diferentes centros de imputação (i.e. "Poderes"), surge a alteração do próprio papel reservado à lei que deixa de ser vista como o foco orientador da vida em coletividade,

\footnotetext{
${ }^{84}$ LOWENSTEIN, Karl. Op. cit., p. 66.

${ }^{85}$ SILVA, Manuel Pascoal Dias Pereira da. Op. cit., p. 81.

${ }^{86}$ Incisivo é Karl LOEWENSTEIN nesse sentido, propondo uma nova divisão de tarefas no Estado Social: "Es difícil desalojar un esquema mental que está profundamente enraizado, y el dogma de la separación de poderes es el más sagrado de la teoría y práctica constitucional. El iconoclasta no puede sentirse satisfecho con sólo remover de su pedestal al ídolo de la triple separación del orden del dominio en los 'poderes' legislativo, ejecutivo y judicial; en su lugar estará obligado colocar otro análises de la dinámica del poder más de acuerdo con la sociedad pluralista de masas de nuestro siglo." (Op. cit., 62.)
} 
portadora de um conteúdo de justiça a orientar a sociedade. Sintetizando com harmonia essas duas faces de uma mesma moeda, anota Luís S. Cabral de MONCADA:

A moderna actividade administrativa não se esgota numa pura execução da norma legislativa, antes se concretizando num variadíssimo conjunto de medidas e providencias 'desenvolvimentistas' e 'salutistas' (Daseinvorsorge) particularmente evidentes no terreno da economia, susceptíveis até de configurar a administração como um poder em ascensão no estado social de direito dos nossos dias e que fazem as suas exigências à caracterização atual do princípio da divisão dos poderes, pois que dilatam radicalmente o âmbito material do poder executivo e da função administrativa. As tarefas da criação de legislação como tarefas centrais do estado, perdem terreno a favor da actividade administrativa; tão importantes como elas se vão afigurando as de conformação da sociedade a cargo estas de um poder especializado, o executivo, cujo peso vai agora alterar o equilíbrio tracional da separação de poderes. Do mesmo modo se volta a colocar na ordem do dia a caracterização do princípio da legalidade da administração"

Analisando as leis (em seu sentido formal) muito há a se observar em relação ao seu conceito no Estado Social. Primeiramente, rejeita-se a lei como produto de uma razão haurida pelo Parlamento, reconhecendo-a como produto de um jogo institucionalizado entre diversos interesses, pondo em causa os ideais de abstração e generalidade que, segundo o pensamento liberal, garantiriam seu conteúdo justo. A pluralidade de forças atuando no Parlamento (opondo-se a homogeneidade liberal-burguesa, assegurada pelo voto censitário) leva a se reconhecer à lei não mais como um instrumento de uma razão transcendente e sim como o produto de um consenso possível, à luz de determinadas circunstâncias. Essa idéia abala os pilares de legitimação da lei e põe a nu a inexistência de uma vontade geral, e sim a existência de diversos grupos, cada qual dotado de interesses bastante próprios. ${ }^{88}$ É o que Carlos de Cabo MARTÍN, ao falar das transformações do conceito de lei, vai chamar de quebra do suposto cultural da lei, definindo o fenômeno nos seguintes termos:

\begin{abstract}
A partir de estas consideraciones se entiende bien que un concepto como la ley, con su carácter de 'representación' general, de expresión de la voluntad e intereses globales y unitarios y máxima encarnación de la racionalidad y de la objectividad jurídico-estatal, esté fuera de la sintonía del momento cultural contemporáneo; de ahí que, por el contrario, conecten plenamente con ese momento procesos distintos como los de fragmentación jurídica y de desformalización con progresiva pérdida de relevancia de los caracteres propios de las 'fuentes formales' del Derecho estatal (supremacía o aplicación general), delegalización y deterioro de la idea de código, así como la emergencia de la autonomía de determinados sujetos y grupos con la correspondiente erosión incluso del concepto de ordenamiento jurídico en cuanto estructura normativa también global ${ }^{89}$
\end{abstract}

\footnotetext{
${ }^{87}$ MONCADA, Luís S. Cabral. Op. cit., p. 44-45.

${ }^{88}$ Neste sentido, consulte-se Floriano Peixoto de Azevedo MARQUES NETO que bem coloca a questão da fragmentação social e seus reflexos sobre os conceitos generalizantes de vontade geral e sua tradução no plano do Direito Administrativo, o interesse público (Op. cit., p. 115-124.)

${ }^{89}$ MARTÍN, Carlos de Cabo. Op. cit., p. 74.
} 
Nesta linha, ganha importância a consideração de que a lei, especialmente no Estado Social, é produto da barganha entre diversos grupos capazes de atuar no processo de sua feitura $^{90}$ o que se afasta radicalmente do ideário liberal.

Outra linha a ser assinalada, diz com alterações no conteúdo da lei. Há casos em que o conteúdo das leis passa a ser, mais e mais, conjuntural e não definido sobre padrões racionais que buscavam a criação de idealizados modelos de conduta, dotados de estabilidade (quiçá, perpetuidade) e destinados à sociedade como um todo. O conteúdo geral e abstrato é golpeado então pela especificidade que vai se agregar ao conteúdo das leis, chamadas a atuar em situações bastante específicas (longe daquela preferência pelo conteúdo universal, tão ao gosto do Liberalismo que remetia, em última análise, a um conteúdo de justiça). No dizer de Luís S. Cabral de MONCADA “(...) assistiu-se também a erosão da racionalidade da lei, transformada agora em instrumento de determinada política e meio de alcançar certos fins, o que lhe exige respostas normativas ditadas sobretudo por considerações de produtividade e eficiência, de modo a prestigiar as orientações políticas que veicula." ${ }^{91}$ No limite, as leis formais passam a conter comandos que materialmente se enquadrariam melhor no conceito de ato administrativo, demonstrando a profunda alteração na idéia liberal de lei. Em outras hipóteses, as leis passam a verter comandos amplíssimos que só tem sua normatividade completada mediante a emanação de um ato a ser procedido pela Administração que defina o seu conteúdo (e mesmo a delimitação do seu objeto). São as chamadas "leis quadro" cuja estrutura, seguindo a metáfora, define uma moldura a ser completada em nível infralegal. Na definição de Carlos de Cabo MARTíN nestes casos "el Derecho no nace propriamente del legislador sino de las decisiones concretas tomadas". ${ }^{92}$

O que importa reter é que as alterações da estrutura legal, despindo-a do seu conteúdo liberal, põem profundos desafios no que toca à relação a ser travada entre quem formula as leis e quem as executa, o que abala a viga mestra do Direito Administrativo. Sobre o tema, anota

\footnotetext{
${ }^{90}$ Retomando a denominação de Massimo Severo GIANNINI, Marçal JUSTEN FILHO manifesta-se nos seguintes termos acerca do Estado Pluriclasse, a desafiar as soluções unívocas em matéria de definição de interesses legítimos da sociedade: "A democracia contemporânea externa-se numa espécie de interminável reorganização dos interesses individuais e coletivos. As composições entre os diferentes grupos de interesses assemelham-se a um processo caleidoscópico, em que cada arranjo é distinto do existente em momentos anteriores e posteriores". (Op. cit., p. 11.) Esta nota implica que o processo de definição dos interesses venha a atender uma lógica procedimental, capaz de garantir consensos.

${ }^{91}$ MONCADA, Luís S. Cabral de. Op. cit., p. 54.

${ }^{92}$ MARTÍN, Carlos de Cabo .Op. cit., p. 78.
} 
Eros Roberto GRAU, colocando o tônus de sua exposição na perda de referencial claro a separar o Executivo do Legislativo, evidenciada de modo patente no conteúdo das leis:

aí a fratura entre hierarquia formal e substancial e a divergência entre força e valor jurídico-formal e relevância efetiva dos atos legislativos e administrativos. A lei torna-se vaga nos seus enunciados, imprecisa nos seus pressupostos de aplicação e elástica em sua determinação; de outro lado, contudo, passa a disciplinar diretamente interesses de segundo grau, mostrando-se imediata e concreta tal qual um procedimento administrativo especial. Na primeira hipótese, a lei se realiza através da prática de um ato administrativo; na segunda, é, em si mesma um ato administrativo especial. ${ }^{93}$

Da conjugação das alterações e desafios postos pelo Estado Social à separação dos poderes e à concepção de lei percebe-se a necessidade de o Direito Administrativo conviver com questões estruturais incapazes de serem compostas com vistas, apenas, aos pressupostos sedimentados no Liberalismo. Na síntese harmoniosa de Maria Sylvia Zanella DI PIETRO:

(...) o acréscimo de funções a cargo do Estado - que se transformou em Estado prestador de serviços, em Estado empresário, em Estado investidor - trouxe como conseqüência o fortalecimento do Poder Executivo e, inevitavelmente, sérios golpes ao princípio da separação de poderes. Já não se vê mais o Legislativo como único Poder de onde emanam atos de natureza normativa. O grande volume de atribuições assumidas pelo Estado concentrou-se, em sua maioria, em mãos do Poder Executivo, que, para atuar, não podia ficar dependendo de lei, a cada vez, já que sua promulgação depende de complexo e demorado processo legislativo. Como conseqüência, passou-se a conferir atribuição normativa ao Poder Executivo, que veio a exercer essa competência por meio de decretos-leis, leis delegadas, regulamentos autônomos. O legislador, em inúmeros casos, passou a adotar a técnica de editar fórmulas gerais, standards, para serem completados pelo Executivo; esse deixou de ser apenas um executor de normas postas pelo Legislativo. ${ }^{94}$

Tais transformações, obviamente, vão reverberar sobre as técnicas operativas que permitem a atuação do Estado e definem o conteúdo da função administrativa. Há necessidade de se adotarem novas soluções no plano da dogmática para dar conta das missões assumidas pelo Estado.

Em relação à categoria que vai explicar o grosso das atividades criadas nesse período, há a emergência do serviço público como uma tarefa reservada à Administração (Estado). À lógica eminentemente restritiva do poder de polícia ${ }^{95}$, soma-se a figura do serviço público,

\footnotetext{
${ }^{93}$ GRAU, Eros Roberto. Op. cit. p. 254.

${ }^{94}$ DI PIETRO, Maria Sylvia Zanella. In Discricionariedade..., p. 31.

${ }^{9} \mathrm{O}$ próprio poder de polícia vai sofrer uma dilatação em relação à sua abrangência passando a atuar em áreas que antes lhe eram estranhas, bem como alteração de conteúdo, passando a impor não só obrigações de não fazer, mas também conhecendo de obrigações de fazer (nesta linha, consulte-se CAIO TÁCITO, in Temas..., p. 524 e Maria Sylvia Zanella DI PIETRO, in Direito..., p.110.) Cumpre ressaltar que parte da doutrina nacional não aceita o conteúdo de obrigações de fazer como decorrente do poder de polícia, valendo por todos a indicação de
} 
categoria que visa a aglutinar os elementos teóricos que estão envolvidos em uma noção de Administração Prestadora.

Sobre a íntima relação entre serviço público e Estado Social, anota Marçal JUSTEN FILHO:

A instituição estatal não pode ser considerada o mero veículo de controle da força, mas tem de se orientar toda à produção de utilidades concretas e benefícios palpáveis para o povo. $\mathrm{O}$ instituto do serviço público é a tradução jurídica da concepção acima exposta. Não seria exagero afirmar que o Estado de Bem-estar Social é o Estado do Serviço Público. O serviço Público é a tradução jurídica do compromisso político da intervenção estatal para satisfazer as carências coletivas. ${ }^{96}$

Embora a noção de serviço público seja antecedente ao Estado Social, à sua difusão deu-se por ensejo da afirmação desse modelo; sendo esta categoria apta a explicar as atuações prestacionais da Administração em face das demandas coletivas. ${ }^{97-98}$ Indubitavelmente a racionalidade inerente à categoria serviço público é a que predomina na explicação dos fenômenos prestacionais da Administração.

Ao lado disso, surge um inegável incremento da utilização por parte da Administração de vias não autoritárias (v.g. a utilização mais ampla de instrumentos de direito privado), redimensionando-se o aparato estatal de modo a conceber estruturas aptas a desempenhar de

Celso Antônio Bandeira de MELLO que é firme ao restringir o instituto apenas às obrigações de não fazer, in Curso de Direito Administrativo. 19. ed. São Paulo: Malheiros, 2005, p. 767-768.

${ }^{96}$ JUSTEN FILHO, Marçal. Teoria Geral das Concessões de Serviço Público. São Paulo: Dialética, 2003, p. 23.

97 Anote-se, por dever de clareza, que outras manifestações prestacionais são possíveis de serem concebidas como a atuação direta do Estado na economia, em regime de competição com a iniciativa privada, utilizadas largamente na Europa Continental após a $2^{\mathrm{a}}$ Guerra. O regime de empresas estatais não é completamente recondutível ao do serviço público (não sendo público em um sentido próprio), todavia, em ambos está presente a nota prestacional. Tais atuações não são redutíveis ao conceito técnico de serviço público, possuindo não raro regime jurídico próprio. No caso francês, como anota André de LAUBADÈRE, o arresto conhecido por " $b a c$ d'Eloka" levou a jurisprudência a não submeter os chamados serviços públicos "industriais e comerciais" à jurisprudência administrativa (em oposição aos "administrativos", sujeitos ao Conselho de Estado) e, sim, à justiça comum, denotando uma duplicidade de regimes no âmbito da administração prestacional. (Op. cit., p. 42.) Todavia, em relação à matéria de fundo, e adotando conceito mais amplo para estes fins, não se procederá à distinção, tratando tudo sobre o rótulo serviço público.

${ }^{98}$ Outra manifestação administrativa que guarda algo de pertinente em relação à Administração Prestacional é o fomento. Por esta via, indiretamente, a Administração incentiva comportamentos particulares de interesse público, especialmente, na área social (fundamentalmente em saúde e educação). Dentro do conceito, todavia, estão usualmente englobadas todas as medidas de apoio à iniciativa privada (alcançando manifestações díspares como a outorga de subvenções, a concessão de benefícios fiscais, cessão de bens públicos) o que dificulta qualquer trato sistemático à matéria. É de se notar inclusive que o modelo de atuação direta do Poder Público sobre os domínios considerados de utilidade social implica em atribuir um espaço manifestamente secundário à atividade de fomento. Sobre fomento aprofundar em Maria Sylvia Zanella DI PIETRO. Op. cit., p. 59. 
modo satisfatório as missões a si impostas. ${ }^{99}$ Não mais subsiste a Administração de organização centralizada, estruturada ao influxo da hierarquia em um bloco monolítico.

No plano da atuação concreta da Administração (a par de um incremento da utilização de vias consensuais de natureza contratual), no que toca ainda a manifestações consagradoras de autoridade, passa a se pôr em causa a idéia de ato administrativo como categoria estruturante do direito administrativo. Ora, em um quadro de acentuada dependência do administrado da Administração, uma categoria pontual como o ato administrativo, apta a explicar a consagração autoritária da vontade do Estado, em relação à liberdade e ao patrimônio particular, não se mostrava de todo satisfatória. No dizer de Vasco Manuel Pascoal Dias Pereira da SILVA “(...) o acto administrativo perdeu a sua posição de quase exclusividade, ou de monopólio, no âmbito das relações administrativas. Em vez de ser a manifestação por excelência do poder administrativo, a forma de actuação-tipo da Administração Pública, ele é, cada vez mais, somente uma forma de actuação entre muitas."

Assim, o desempenho da função administrativa deixa de ser examinado em relação, apenas, ao seu produto final ${ }^{100}$ que expressa uma decisão tomada pela Administração. Passa a considerar, também, o caminho que une a potência ao ato, bem como a natureza das relações estabelecidas entre o particular e a Administração. Se antes a natureza da relação era inteiramente definida por meio da conformação legal, bem como era relevante apenas a vontade manifestada com autoridade por meio do ato, a dependência do cidadão no Estado Social passa a pôr em mira outros elementos. ${ }^{101}$ Nesta linha, o procedimento e a natureza da

\footnotetext{
99 Sobre o tema, consulte-se com proveito, Maria João ESTORNINHO (Op. cit., passim) no qual há um interessante estudo sobre o uso do direito privado pela Administração, com reforço da paridade, nestas hipóteses, entre Estado e cidadão. Como anota a autora, na página 46, é uma das características da Administração do Estado Social a dualidade de regimes (público/privado), estruturado sobre a noção de atos de gestão pública e atos de gestão privada, que revive, em certo sentido, a velha teoria do Fisco.

${ }^{100}$ Em uma linha similar à presente, de superação do conceito de ato administrativo como categoria estruturante do Direito Administrativo pós Estado Liberal, tem-se a recente opinião de Marçal JUSTEN FILHO: "O conceito de ato administrativo perdeu sua relevância como instrumento de compreensão e organização o direito administrativo. O fundamental está em considerar a atuação administrativa de modo global, não cada ato administrativo isoladamente." (in Curso..., p. 137.)

${ }^{101}$ Em exaustivo estudo sobre o tema, Vasco Manuel Pascoal Dias Pereira da SILVA anota três linhas que buscam enfrentar a crise do ato administrativo (que nada mais é do que a crise do Estado Social, setorizada). Uma primeira linha, que ainda admite lugar sobranceiro ao ato administrativo, malgrado a necessidade de cunharem-se novos conceitos para analisar os desafios postos; é a orientação prevalente na doutrina francesa e portuguesa. Outra orientação que busca criar um regime todo novo para a Administração Prestadora, reservando o ato administrativo apenas para a Administração Agressiva (criando um hibridismo, fundado na incompatibilidade entre os dois campos). É a linha do que defende parte da doutrina alemã, com destaque para a opinião de Ernest FORSTHOFF. E, por fim, uma terceira linha que busca refundar a dogmática do Direito Administrativo, com estribo em noções que suplantem o velho conceito de ato administrativo. Duas noções têm disputado esse suposto
} 
relação administrativa passam a ser objeto de consideração do Direito Administrativo, ${ }^{102}$ o que não tinha relevo no Estado Liberal, focado apenas na declaração de vontade produzida no exercício da função administrativa, dotada de autoridade.

Sem qualquer pretensão de esgotar o tema ora em exame, pois, cada um dos vértices ora entrevistos suportasse inúmeras outras considerações, o panorama feito pelo Estado Social (buscando seu cotejo com o Estado Liberal) e o modo de se conceber o exercício da função administrativa à luz desse modelo, basta para demonstrar o ponto fundamental. À luz da emergência desse sistema altera-se profundamente o direito; e, em especial, o Direito Administrativo é alvo de intensas mudanças que devem ser compreendidas, desde uma perspectiva genérica, para se compreender as questões da atualidade.

Com as explicitações já feitas, de que um modelo não se presta à explicação completa da realidade e apenas para ressaltar características mais relevantes (à moda de uma caricatura), bem como de que a superação de um paradigma, em especial em ciências culturais, não implica a supressão completa do anterior, a análise procedida busca exatamente demonstrar os aspectos da emergência do Estado Social que conduziram a alterações no Direito Administrativo.

Sintetizando, o a função administrativa no Estado Social passa a ser concebida como uma atividade destinada a outorgar, concretamente, materialidade aos cidadãos. As categorias de atuação do Direito Administrativo passam a ter que explicar essa atividade de aumento do patrimônio jurídico dos indivíduos, não mais se contentando apenas com justificar a intervenção estatal sobre o patrimônio jurídico dos cidadãos de modo a lhes restringir os direitos de liberdade e propriedade. Ainda que em um sentido amplo, a categoria que vai explicar a racionalidade de tais atuações é o serviço público, cuja teorização, desde logo, demonstra a preocupação em salvaguardar o direito de os cidadãos terem acesso contínuo e adequado às atividades consideradas essenciais ao desenvolvimento humano.

\footnotetext{
vácuo que seria deixado pela ausência do ato administrativo como categoria estruturante. Uma, prevalente na Alemanha, perfilada ao influxo do conceito de relação administrativa e outra, majoritária na Itália, estruturada ao redor da categoria procedimento. (Op. cit., passim.)

${ }^{102}$ Sobre os conceitos de relação administrativa e procedimento, veja-se na doutrina nacional a obra de Egon Bockmann MOREIRA: Processo Administrativo - Princípios Constitucionais e a Lei 9784/1999. 2. ed. São Paulo: Malheiros, 2003, p. 25-28; 37-43, respectivamente.
} 


\subsection{ESTADO PÓS-SOCIAL E CARACTERIZAÇÃO DA FUNÇÃO ADMINISTRATIVA (O MOMENTO DA CRISE)}

Seguindo na linha de apresentação proposta, cumpre analisar o momento mais atual, o chamado Estado Pós-Social, que emerge das reformas no modelo que lhe antecede, não sem antes destacar o efetivo sucesso alcançado por ele na promoção do progresso humano. ${ }^{103} \mathrm{~A}$ exemplo do Estado Liberal, o Estado Social tem um papel fundamental ao seu tempo, carecendo, contudo, de se adaptar aos novos tempos; há o apogeu e há a queda.

Novamente, o modelo de Estado adotado deixa sem cumprir suas promessas, impondo reforma de alguns de seus corolários (sem supressão radical da idéia de fundo de solidariedade social). Em relação às vicissitudes do Estado Social, usualmente são apontadas algumas falhas desse sistema (tanto no plano social quanto jurídico), desnudando aspectos negativos de sua implantação. Maria Sylvia Zanella DI PIETRO, aponta as seguintes características negativas, desde o ponto de vista jurídico: (i) hipertrofia do Executivo, em detrimento dos outros Poderes; (ii) perda da credibilidade da lei enquanto portadora de idéias de organização justa da sociedade e inflação legislativa; (iii) atribuição de largas parcelas de função normativa ao Executivo, contribuindo para o agravamento do quadro de instabilidade em relação à ordenação das missões estatais; (iv) diminuição da força do controle judicial das atividades da Administração em face da perda de valores dos atos normativos, reduzindo a análise a aspectos meramente formais e (v) a perda de um valor inerente ao direito, que passa a ser um mero instrumento de atuação técnica do Estado, deixando de lado seu conteúdo de garantia que refletia uma preocupação com o limite da intervenção estatal sobre a esfera individual. ${ }^{104}$

Ainda mais aguda é a constatação das mudanças sociais que redundaram na imposição de transformações ao modelo de Estado Social, não mais capaz de se acomodar de modo completamente harmônicos às alterações que se lhe apresentavam. Nesta perspectiva, Odete MEDAUAR faz a suma de alguns pontos que levaram à crise do modelo: (i) crise de financiamento, no sentido de que a manutenção do modelo, em face do aumento exponencial

\footnotetext{
${ }^{103}$ Marçal JUSTEN FILHO destaca com pertinência o sucesso do modelo do Estado Social: "As condições de vida elevaram-se a níveis nunca antes experimentados. A expectativa de vida média da população elevou-se radicalmente. Nunca anteriormente os seres humanos experimentaram tamanho conforto e tão grande quantidade de benefícios. Mais do que isso, nunca na história se ofertaram benefícios em termos tão democráticos: saneamento, educação, assistência, previdência foram assegurados para todos os cidadãos, em condições de igualdade (ao menos, formal)" (in O Direito das Agências Reguladoras Independentes, São Paulo: Dialética, 2002, p. 18).

${ }^{104}$ DI PIETRO, Discricionariedade..., p. 32-33.
} 
dos gastos sociais, tornou-se economicamente inviável, impedindo a alocação de recursos em novos projetos sociais e deteriorando os sistemas prestacionais já existentes, de um certo modo as pessoas aptas a contribuir com o financiamento estatal não dão cabo das demandas postas por aqueles que não contribuem; (ii) um exacerbado déficit em relação à segurança física dos cidadãos e (iii) crise de governabilidade decorrente da estrutura do Estado que torna sobremaneira difícil implementar concretamente as missões a seu cargo, levando à questão do redimensionamento do aparato estatal. ${ }^{105}{ }_{-} 106$

Embora seja extremamente complexo fazer uma síntese dos elementos que estão na definição dessa crise (haja vista as diversas abordagens ensejadas e a sua atualidade, o que não permite a visualização de uma perspectiva segura) uma nota comum aos autores que dela cuidam são a necessidade de redimensionar o papel do Estado (tanto em relação ao tamanho quanto em relação ao modo de atuação) em sua relação com a sociedade civil, haja vista uma crise de legitimidade em relação às atuações públicas, tidas por ineficientes e onerosas. ${ }^{107}$

\title{
Como sintetiza Maria João ESTORNINHO
}

\begin{abstract}
Ao crescimento desmesurado da Administração Pública do Estado Social associam-se fenómenos graves de ineficiência e de aumento da burocracia. Por outro lado, o agravamento das contribuições exigidas aos cidadãos para suportar as despesas crescentes da máquina estatal e a falta de imparcialidade do Estado (para já não falar de fenómenos extremos, com os de corrupção) suscitam, cada vez mais, uma reacção generalizada de desconfiança e incomodidade do cidadão em face do poder público. Por tudo isto, aos poucos, começa-se a pôr em causa o próprio crescimento do Estado e das funções por ele desempenhadas e defende-se a necessidade de repensar a dimensão da máquina administrativa e os tipos de tarefas que a seu cargo devem ser colocadas. ${ }^{108}$
\end{abstract}

A única certeza que parece haver é a existência efetiva da crise, sem que se tenha, entretanto, a compreendido na sua inteireza. Analisando o tema "universalidade da crise", diz Vasco Manuel Pascoal Dias Pereira da SILVA: "Esse diagnóstico de crise do Estado social é hoje compartilhado à direita e à esquerda, por correntes que vão do neoliberalismo

\footnotetext{
${ }^{105}$ MEDAUAR, Odete. Op. cit., p. 90-93.

${ }^{106}$ Em sentido similar à manifestação de Odete MEDAUAR consulte-se à opinião de Pedro GONÇALVES e Licínio Lopes MARTINS: "As raízes dessas alterações remontam às primeiras crises do Estado social por volta dos anos sessenta, e que viriam a tornar-se mais visíveis com o decurso do tempo: os gastos públicos exponenciais do sector público, a carga fiscal necessária para o seu financiamento, o déficie público incontrolável, a ineficácia e ineficiência da gestão pública são em geral considerados os principais fatores da viragem verificada." (Op. cit., p. 180.)

${ }^{107}$ Neste sentido manifesta-se Vasco Manuel Pascoal Dias Pereira da Silva acerca da crise que marca o Estado Social (Op. cit., 122-123.)

${ }^{108}$ ESTORNINHO, Maria João. Op. cit., p. 47.
} 
conservador ao socialismo marxista da 'escola de Frankfurt', passando pelas tendências do pós-socialistas e pós-social-democratas'."109

Novamente então se faz necessário superar o modelo anterior em alguns pontos, mantendo outros ainda vivos. Neste sentido, importa destacar que o Estado Pós-Social não rompe por completo com a lógica intervencionista do Estado e não põe a perder certos conteúdos de garantia dos administrados. ${ }^{110}$ Ainda, reconhece-se que se mantém presente um dever de atuação do Estado de modo a garantir a promoção de certas missões sociais (conquista essa do modelo anterior preservada na atualidade). Antes, todavia, de analisar as alterações procedidas é interessante notar que desde a emergência do Estado Pós-Social, esse modelo foi contrastado com diversas alterações conjunturais que impõem a revisão do quadro do Estado Social. ${ }^{111}$

Há diversos fenômenos (e uma infinidade de rótulos) associados ao período dos dias atuais de modo a definir-se o modelo estatal. Está-se diante daquilo que já se chamou com propriedade de "Estado desafiado". Sem prejuízo de outras análises possíveis, parece inegável que estão a influenciar esse fenômeno uma nova perspectiva em relação à atuação dos Estados no cenário internacional (chamada usualmente de globalização) e um novo arranjo dos interesses da sociedade civil, cada vez mais pulverizada em relação aos seus interesses, hoje absolutamente heterogêneos e, pois, incapazes de serem conduzidos a grandes categorias unificadoras. ${ }^{112}$

Sabino CASSESE, em um estudo que busca desvendar os reflexos de um "espaço jurídico global", arrola uma série de transformações decorrentes da ampla internacionalização

\footnotetext{
${ }^{109}$ SILVA, Vasco Manuel Pascoal Dias Pereira da. Op. cit., p. 124.

110 Anota sobre o assunto Maria Sylvia Zanella DI PIETRO: "A referência ao período atual não significa superação do Estado Democrático de Direito. Significa, isto sim, o acréscimo e alguns aspectos novos, por conta do fenômeno da globalização, do neoliberalismo, do princípio da subsidiariedade e, em conseqüência, da chamada Reforma do Estado ou, mais especificamente, Reforma Administrativa." (in Discricionariedade..., p.52.)

${ }^{111}$ Está-se a referir com a expressão ao "conjunto de fatores que, no campo econômico, social e político, concorrem para a construção de um cenário de desafios ao Estado Moderno e, por conseqüência, ao modelo jurídico-administrativo que lhe é inerente" (cf. define Floriano Peixoto de Azevedo MARQUES NETO. Op. cit., p.102.)

112 Sobre o tema "Estado desafiado", consultar o amplo estudo de Floriano Peixoto de Azevedo MARQUES NETO que aborda os reflexos dessas tendências para a estrutura do Estado, nos seus aspectos econômico, social e jurídico (Ibidem, p. 100-143.)
} 
das relações. ${ }^{113}$ As suas conclusões são bastante interessantes de serem postas em cotejo com o que está se expondo em relação ao tema. ${ }^{114}$

Duas notas essenciais, conforme anota Sabino CASSESE, caracterizam a globalização: (i) difusão acelerada e generalizada das tecnologias de comunicação e (ii) incremento das relações transnacionais (transfronteiriças) de bens, serviços e capitais. Absolutamente, não vigem mais os padrões nacionalistas em matéria econômica. Há uma internacionalização da produção que torna até difícil saber onde determinado bem é produzido, tornando fluídas as fronteiras econômicas. Os sistemas econômicos interligam-se de modo que crises em centros econômicos têm reflexos instantâneos e imediatos em economias periféricas.

Há, ainda, um incremento do caráter multinacional das empresas que lhes agrega pujança na ordem econômica (conceito de grande empresa). Não mais é o Estado o ator do comércio internacional, há compartilhamento de espaço com empresas transnacionais (a título de ilustração dos 100 maiores organismos econômicos do mundo, 51 são empresas sendo que a Nokia girou um volume de dinheiro superior à Finlândia, país de sua sede, no ano de 2000, conforme dados coligidos no estudo de Sabino CASSESE).

O termo globalização além de não ser recente - tendo sido mencionado no Manifesto Comunista, por exemplo - não é sequer coerente. Ao invés de implicar a globalização na redução do fenômeno estatal, implicou em sua majoração, ao menos em termos quantitativos (por exemplo, aumentando-se o número de países existentes). Acerca do tema globalização, buscam-se usualmente algumas explicações. A primeira é identificar o assunto com um período de anarquia e caos institucionalizado. A segunda, diz com a identificação do fenômeno como pura expressão do imperialismo norte-americano (esta visão falha diante da constatação de que nem só os EUA participam do fenômeno, estando ela aberta a diferentes países). A identificação da globalização com o caos também não logra explicar o fenômeno, pois, percebe-se o surgimento de estruturas jurídicas supra nacionais a regular estas interrelações transnacionais (especialmente no âmbito comercial).

\footnotetext{
113 O tema "globalização" é amplíssimo de modo que prestigiou-se o pensamento de um autor que está especialmente atento acerca das transformações postas por esse fenômeno ao direito administrativo. Para uma análise mais concisa sobre o tema globalização e direito administrativo, consulte-se Marçal JUSTEN FILHO (in Curso..., p. 16-17) e Alexandre Wagner NESTER, Regulação e Concorrência (compartilhamento de infraestruturas e redes), São Paulo: Dialética, 2006, p. 60-77.

${ }^{114}$ In Lo spazio giuridico globale, Rivista trimestrale de diritto pubblico, n. 2, 2002, p. 323-339. É com base neste texto que estão analisadas as relações entre globalização e Direito Administrativo, sem prejuízo de muitas outras possibilidades de análise que o tema suscitaria. Tal opção justifica-se haja vista o tônus específico da análise do autor italiano ser a compreensão das alterações vividas sobre o campo jurídico.
} 
Assim, nitidamente há uma ordenação da globalização (do espaço jurídico global), que deve ser compreendida, em especial por alterar as relações jurídicas subjacentes.

Em relação a esta ordem, percebe-se que ela não é dotada de uma Constituição ou mesmo de um Governo, regendo-se de forma peculiar. Há presença de um elemento subjetivo (ainda que multifacetado), uma organização própria (principalmente em face de organizações internacionais) e uma normatização (ainda que em aspectos um tanto quanto novos, de natureza regulamentar não estatal) que devem ser analisadas para estudar este fenômeno.

Não há uma autoridade superior, funda-se a ordem da globalização na cooperação e integração entre os seus partícipes. No tocante à ausência de Governo (e da regulação por meio do consenso), apontam-se como vantagens disso uma maior flexibilidade e um ambiente que prestigia a circulação de bens e informações. Todavia, critica-se a ausência de direção central: em relação à instabilidade do modo consensual (mudança das regras do jogo, por vontade da maioria); a dificuldade de se obter o consenso em alguns casos e o recurso a votações com quoruns qualificados, a formação de blocos de votação e, ainda, a possibilidade de se desrespeitarem minorias.

A diferença desta ordem para as fundadas na autoridade de um ente superior (soberano) é que no novo paradigma há um alto grau de institucionalização o que implica, em última análise, em diferentes fontes de produção do fenômeno jurídico, também no plano externo.

A ausência de natureza centralizada, segundo Sabino CASSESE, implica nas seguintes características acerca do espaço jurídico global: (i) aspecto fragmentado, sendo a ordem policêntrica e reticular (imagens que se contrapõem à velha e monolítica pirâmide normativa); (ii) $\mathrm{O}$ ordenamento apresenta-se como incompleto e assimétrico, não havendo uma indicação precisa de tarefas e atribuições entre os diferentes atores (o que implica em um aumento de discrição) e (iii) formado por entes supranacionais.

Estes entes nacionais agem por meio de esquemas que não podem ser reconduzidos aos atos clássicos que externam poder, exercendo uma grande gama de tarefas distintas a serem executadas em diversos locais. Podem suas ações ser de natureza indireta, servindo de fórum para algumas discussões ou criando demandas sociais a serem satisfeitas pelo Estado. Ainda, podem estes entes exercer papel ativo visando a influenciar a conduta do próprio Estado. Vê- 
se, pois, que há importância nas tarefas desenvolvidas por estes entes, levando à necessidade de estudar a legitimação de seu agir.

Em relação à legitimação, parece conforme o autor italiano, superada a idéia de uma democracia cosmopolita, que se mostra inviável. É, pois, necessário buscar outras formas de legitimação não devendo se superestimar a democracia que também apresenta falhas graves no que toca a ser um sistema de legitimação do poder. Usualmente, apontam-se as seguintes falhas na concepção que traduz legitimação em democracia no que tange ao espaço global: (i) a ausência de democracia direta esgota um pouco de seu conteúdo não se devendo superestimá-la em relação ao seu papel político, havendo diversas falhas no modelo de representação; (ii) busca de transporte imediato para a ordem global da democracia direta, o que reflete o mito de o Estado ser a única forma possível de racionalização do poder; é de se perceber que, segundo o autor, a ordenação global vem, não para restringir o patrimônio jurídico dos cidadãos (o que legitima a idéia de aceitação "consensual" da restrição, via Parlamento), e, sim, para aumentar as suas potencialidades, o que the atribui um regime próprio - ampliação da esfera privada - não precisa se alcançar um consenso democrático, pois, não se cuida de submeter os cidadãos a obedecer a novos comandos e (iii) o último vício seria menoscabar a garantia que a ordem global pode conferir aos cidadãos por conta de seu aspecto fragmentário (certamente maior que em havendo um "poder central" fundado em uma "democracia cosmopolita").

O modo de legitimação não é o consenso e, sim, o direito, por meio de uma produção que atenda aos imperativos do due process of law (publicidade, participação e motivação são dimensões tocadas pelo autor).

No ordenamento global, reconhece-se, eminentemente, uma função normativa e uma jurisdicional. Normativamente as figuras são mais complexas que as conhecidas no âmbito interno tendo por justificativa os direitos fundamentais. Há a produção de normas entre Estados e normas setoriais. Em relação às características destas normas apontam-se as seguintes: (i) adoção de preceitos indicativos de matriz promocional e não imperativos (soft law, droit mou); (ii) presença de efeitos laterais, ou seja, normatização bastante ampla; (iii) ausência de rígida prescrição em relação à competência, o que implica em um maior grau de abstração a ser preenchido pelo caso concreto e (iv) diversidade de efeitos (nacionais, supranacionais e internacionais). 
No que toca à resolução de controvérsias, é de se assinalar que as decisões do ordenamento global repercutem de forma ampla influenciando diversas condutas. É de se assinalar também uma nota de criação pretoriana de direitos na ordem internacional (judgemade law).

A função executiva, conclui Sabino CASSESE, é menos desenvolvida na ordem global, haja vista, os Estados não transigirem em relação a ela, sendo atribuição bastante cara a eles. Assim, costumam os Estados reservar para si a função de executar os comandos, não se afastando desta tarefa em benefício da ordem global, uma vez que muitas decisões a serem seguidas são definidas além das fronteiras de qualquer Estado.

A enunciação do pensamento do publicista italiano acerca da ordem jurídica global visa a destacar a relativa similitude de efeitos das alterações supra-estatais com as transformações decorrentes das mudanças de estrutura interna.

Em ambos os casos, o Estado é posto em desafio por uma miríade de interesses diversos, tendo que efetivar entre eles opções com base em procedimentos que justifiquem a seleção das escolhas adotadas.

A idéia clássica de lei e de separação de poderes, nesta trilha, sofre um profundo acirramento dos questionamentos que se põe desde o Estado Social; cada vez mais, seja no âmbito da repartição estatal de funções, seja no âmbito do conteúdo próprio de cada ato, os limites tornam-se imprecisos. Determinados modos de atuação passam, então, a desafiar os esquemas que classicamente se punham para a compreensão da dinâmica do exercício do Poder Estatal. Apenas para ilustrar a gravidade do tema, importa assinalar a conclusão de Carlos de Cabo MARTín acerca do moderno conceito de lei, haurida ao fim do seu estudo sobre este tema:

No cabe seguir - se sostiene - la tesis dualista que distingue entre ley formal y ley material. Los argumentos contra esa distinción son básicamente éstos: que todo los actos estatales, jurídicamente relevantes, crean Derecho; que no hay actos estatales materialmente puros, pues todos participan de sus distintas funciones; la inutilidad práctica de la distinción a efectos del objetivo que se pretendía de distinguir también la eficacia de la ley formal respecto de la forma y material; la inseguridad del criterio para definir a unas leyes como formales y a otras como materiales y, sobre todo y de manera general, porque los supuestos político-jurídicos de la actual fase del constitucionalismo democrático son incompatibles con los que servían de base a esa diferenciación. ${ }^{115}$

\footnotetext{
${ }^{115}$ MARTÍN, Carlos de Cabo. Op. cit., p. 97.
} 
Os reflexos destes desafios se fazem sentir, como não poderia deixar de ser, na concepção de função administrativa, pondo em causa a idéia do papel reservado à Administração (o que toca às idéias de partição do poder dentro do Estado e à dinâmica da função normativa). De um certo modo, os desafios já postos pelo Estado Social são agravados à luz do Estado Pós-Social.

A necessidade a dar resposta satisfatória a uma variedade de interesses sociais é a característica da Administração Pública Pós-Social. Como anota com argúcia Floriano Peixoto de Azevedo MARQUES, não se pode mais trabalhar com a idéia de interesse público como um bloco monolítico, impondo a necessidade de legitimar, caso a caso a atuação concreta do Estado em vista desse mosaico: “(...) perde sentido a noção universal absoluta, singular de interesse público, definido unilateral e autoritariamente pelo Estado (quer por meio da lei, quer, mais posteriormente, por meio do aparato burocrático no exercício de sua crescente margem de discricionariedade)."

Diante de um quadro de tal gravidade, altera-se profundamente o exercício da função administrativa, não podendo se reconhecer a priori a validade de critérios estabelecidos sobre outras bases (como a concepção uma de interesse público).

O desafio posto pela nova estrutura do Estado impôs uma missão mais ampla à Administração do que apenas limitar a liberdade ou resguardando prestações; é necessário que a função administrativa passe a gestionar uma série de interesses (sejam internos, sejam externos) havidos, de modo legítimo, no seio da sociedade, garantindo acesso para demandas concretas/atuais e, ainda, para as potenciais, futuras. Há uma valorização da decisão técnica, como idônea para harmonizar esses conflitos. ${ }^{117}$ Surge um alto grau de conflituosidade entre os interesses havidos, reclamando que a Administração os harmonize por meio de suas atuações.

Há a necessidade de a Administração estruturar condições concretas do desenvolvimento social passando a atuar neste sentido. Nesta ótica, a missão que se impõe

\footnotetext{
${ }^{116}$ MARQUES, Floriano Peixoto de Azevedo. Op. cit., p. 156.

117 "O poder executivo, onde mais claramente se fizeram notas as exigências da nova orgânica do estado para dar cabal cumprimento às tarefas de intervenção na economia, sofreu correspondentemente uma transformação profunda nas suas funções. Já lhe não compete assegurar somente a execução das leis parlamentares, assumindo como que uma vida autónoma não só para funcionar como centro de integração e composição de interesses sociais e económicos os mais variados e até conflituantes chamados à primeira linha pela composição das entidades técnicas mas também como mediador entre os saberes técnicos." (Luís S. Cabral de MONCADA. Op. cit., p. 72.)
} 
transcende as idéias dos paradigmas anteriores, pois, sequer se trata de prestar concretamente utilidades a serem fruídas pela sociedade, mas de garantir o desenvolvimento do todo social aferindo a legitimidade dos diversos interesses que se colocam. Veja-se que esta nova missão (que, insista-se, passa além do mero âmbito prestacional) dá uma nova conotação às missões da Administração.

Dissertando sobre essas missões, de uma Administração dita de infra-estrutura, manifesta-se Vasco Manuel Pascoal Dias Pereira da SILVA:

\begin{abstract}
Na verdade, aquilo que caracteriza a Administração Pública de hoje, mais do que cada um dos seus actos isolados, é a dimensão social dessa activiade, são os efeitos que ela produz relativamente à sociedade no seu conjunto. Essa dimensão 'infra-estrutural' da Administração manifesta-se, não apenas quando a Administração actua de através de actos genéricos (o que é cada vez mais frequente), mas também quando a Administração actua de forma individual, uma vez que esses actos, na grande maioria dos casos, não afectam unicamente os seus imediatos destinatários mas produzem efeitos que vão muito para além das pessoas por eles directamente visadas (v.g. subvenções, autorizações de construção, de abertura de uma fábrica ou de um estabelecimento comercial). Desta forma, 'paulatinamente emerge como marco orientador do direito administrativo', não tanto a concreta prestação ou a soma das efectivas prestações, como o perfil do conjunto das normas como sistema integrado, bem como a sua utilidade social. ${ }^{118}$
\end{abstract}

Ou seja, toda a atividade da Administração (geral ou concreta) passa a integrar um cosmo a que incumbe dar condições para o desenvolvimento da sociedade, compatibilizando, de modo eficiente, as demandas sociais, levando em conta uma série de interesses que muitas vezes se mostram conflituosos (v.g. tutela do meio ambiente e desenvolvimento econômico; proteção de valores históricos e gestão fundiária defesa do consumidor e universalização de serviços públicos).

Nessa perspectiva, altera-se radicalmente o modo de atuar do Direito Administrativo que deve achar novas categorias para orientar sua atividade, cada vez mais dotadas de flexibilidade. Arrolando as características da dita Administração de Infra-estrutura, o publicista português acima citado, traz as seguintes características desse novo modelo: (i) multilateralidade, que supondo a pluralidade de interesses no corpo da sociedade, impõe a consideração de relações entre Estado e cidadãos com uma miríade de partícipes (em detrimento de relações meramente bilaterais, mesmo decisões simples podem vir a ter reflexos nos interesses de terceiros, o que deve ser levado em conta no agir; (ii) caráter continuado dos vínculos, acentuando uma nota presente desde o Estado Social, dotando-os de maior

\footnotetext{
${ }^{118}$ SILVA, Vasco Manuel Pascoal Dias Pereira da. Op. cit., p. 128.
} 
estabilidade, suplantando a lógica de um atuar pontual; (iii) perda da distinção clara entre atos genéricos e concretos, há atos que encerram uma natureza incapaz de ser reduzida com perfeição a estas categorias (v.g. decisões setoriais, com vistas a implementar uma finalidade específica), bem como, mesmo atos concretos, por força de criarem precedentes a serem seguidos, assumem alguma nota de normatividade para o futuro. ${ }^{119}$

Neste prisma, ganham fundamental importância categorias que expliquem a atuação da Administração levando em conta os vários interesses envolvidos garantindo a ampla participação dos interessados.

A legitimação das decisões passa a obedecer uma lógica processual, assegurando a transparência e a controlabilidade delas. ${ }^{120}$ Sinteticamente, anota Marçal JUSTEN FILHO acerca do tema: "Tal como antes afirmado, um problema inafastável é a pluralidade de princípios e interesses, todos relevantes e merecedores de respeito. A procedimentalização propicia oportunidade a que todos os interesses sejam expostos ao exame público, com defesa dos diversos pontos de vista." 121

Como corolário da idéia de redimensionamento da relação entre Estado e cidadão, passa a ser valorada a idéia de subsidiariedade, ${ }^{122}$ tomada da doutrina social da Igreja Católica. ${ }^{123-124}$ Busca se compatibilizar a idéia de necessária intervenção do Estado na promoção do bem-estar (Estado Social) com o respeito a esferas de atuação tipicamente

\footnotetext{
${ }^{119}$ Ibidem, p. 128-135.

120 Anota sobre o tema Diogo de Figueiredo MOREIRA NETO: "Com efeito, a idéia do processo como instrumento de legitimação na filosofia moderna, especialmente na ética política, fruto da racionalidade argumentativa, tem merecido a atenção dos mais conspícuos pensadores do Direito contemporâneo." (in Direito Regulatório, Rio de Janeiro: Renovar, 2003, p. 156.)

${ }^{121}$ JUSTEN FILHO, Marçal. Curso..., p. 64.

122 Sobre o tema indicam-se as seguintes obras: José Alfredo de Oliveira BARACHO. Princípio de Subsidiariedade, Rio de Janeiro: Forense, 1996; Margarida Salema d'Oliveira MARTINS. O princípio da subsidiariedade em perspectiva jurídico-política, Coimbra: Almedina, 2003; Fausto de QUADROS. O princípio da subsidiariedade no direito comunitário após o tratado da União Européia, Coimbra: Almedina, 1995; Rute Gil SARAIVA. Sobre o princípio da subsidiariedade (gênese, evolução, interpretação e aplicação), Lisboa: Associação Académica da Faculdade de Direito de Lisboa, 2001 e Sílvia Faber TORRES. O princípio da subsidiariedade no direito público contemporâneo, Rio de Janeiro: Renovar, 2001.

${ }^{123}$ Pode-se, abstraindo as dificuldades inerentes ao tema, trazer o conceito de subsidiariedade da encíclica Quadragesimo Anno, do Papa Pio XI, de 15/05/1931: "Verdade é, e a história o demonstra abundantemente, que, devido à mudança de condições, só as grandes sociedades podem hoje levar a efeito o que antes podiam até mesmo as pequenas; permanece, contudo, imutável aquele solene princípio da filosofia social: assim como é injusto subtrair aos indivíduos o que eles podem efetuar com a própria iniciativa e indústria, para o confiar à coletividade, do mesmo modo passar para uma sociedade maior e mais elevada o que sociedades menores $e$ inferiores podiam conseguir, é uma injustiça, um grave dano e perturbação da boa ordem social. O fim natural da sociedade e da sua ação é coadjuvar os seus membros, não destruí-los nem absorvê-los." (n. 79).

${ }^{124}$ Para uma breve análise de alguns conteúdos defendidos pela Doutrina Social da Igreja e a sua pertinência com alterações no direito consulte-se Alberto VENÂNCIO FILHO. Op. cit., p. 16-19.
} 
privadas, que não podem vir a ser anuladas. Trata-se de idéia que busca restabelecer a articulação público/privado sobre novas bases. Aliás, a própria idéia de regulação, a ser vista mais detidamente adiante, incorpora a noção de subsidiariedade. ${ }^{125}$

O princípio encerra em seu bojo dois aspectos indissociáveis que lhe dão consistência teórica, não se podendo menoscabar nenhum deles sem prejuízo da sua unidade. $\mathrm{O}$ primeiro desses elementos pode se caracterizar como um limite negativo à atuação do Estado. Limite este, que existe na exata medida em que um determinado grupo social, ou mesmo os indivíduos conseguem, por si só, suprir suas demandas. Neste caso, fica interditada a atuação do Estado que estaria, caso viesse a atuar, em última análise, a violar a esfera jurídica das ordens inferiores sem justificativa justa para tanto. Todavia, nada obstante esta definição de um limite negativo em que o ente estatal não deve atuar, cria-se ao lado dele um campo onde, verdadeiramente, configura-se um dever de ação do Estado (caráter positivo), que deve ser posto em marcha sempre que as ordens inferiores não conseguirem efetivar por si suas demandas. Ou seja, quando a ordem inferior não é capaz, por seus próprios meios, de prover a si elementos fundamentais, deve agir o Estado, não havendo justificativa para não o fazer.

Assim, aponta-se tanto um caráter negativo quanto um aspecto positivo interentes ao princípio, que têm como justificativa a própria esfera reservada aos ordenamentos menores e sua capacidade de prover os seus meios (autonomia). Este é o elemento a determinar a necessidade de ação ou não ação do Estado (ou outra ordem superior quando for este o caso). Ainda, como assinala Maria Sylvia Zanella DI PIETRO, há a necessidade de o Estado dar suporte às atividades dos particulares, de modo a dar meios que eles possam atuar sem a necessidade de auxílio de uma ordem superior. ${ }^{126}$ Cria-se, claramente, um ideal de que os particulares, por si, promovam organizados em face de seus interesses, o seu próprio desenvolvimento. Há, assim, uma preferência em relação à iniciativa privada, que dá sustentação teórica aos movimentos de redimensionamento do Estado.

Visto o caráter dúplice do princípio, impende analisar as condições para que se legitime a ação do Estado. O primeiro dos elementos é logicamente a incapacidade de uma ordem inferior prover os seus meios de maneira autônoma. No entanto, só isto não basta. É

\footnotetext{
125 Como sintetiza Marçal JUSTEN FILHO: "A regulação incorpora a concepção de subsidiariedade." (O Direito..., p. 21.)

${ }^{126}$ DI PIETRO, Maria Sylvia Zanella. Opinião defendida em Parcerias na Administração Pública, 3. ed. São Paulo: Atlas, 1999, p. 25.
} 
necessário que, além disto, a ordem superior seja capaz de prover estes meios de maneira mais eficiente do que a ordem inferior o faria. Sobre o tema, anota Fausto de QUADROS: "Portanto, a necessidade da prossecução daquela atividade e a maior eficácia da comunidade maior nessa prossecução são os dois requisitos da concretização e da aplicação do princípio da subsidiariedade." 127

Do tudo que se expôs até agora acerca do Estado social outras características podem ser arroladas, como manifestação das linhas apontadas. Em face de se advogar um espaço de atuação mais amplo em prol dos cidadãos surge uma série de técnicas visando à redução do aparato estatal ao que, usualmente, denomina-se privatização (em sentido amplo ${ }^{128}$ ). Mesmo a idéia de subsidiariedade, a orientar a relação entre Estado e sociedade, remete à idéia de diminuição do aparato público. ${ }^{129}$

A necessidade de coadjuvar os interesses do público e do privado aumenta a necessidade de recursos a formas que permitam a gestão compartilhada de atividades, conjugando esforços entre a Administração e os administrados. É a idéia de parceria. Surge uma série de institutos que visam a instrumentalizar essa nova modalidade de arranjo entre particulares e o Estado, com a novidade de que por meio desses os atores privados podem estar atuando interesses que não se reduzem à busca de lucro. Todas as idéias acerca do chamado terceiro setor gravitam sobre esse eixo.

Outra característica desse novo modelo é uma maior utilização das vias de direito privado, de modo a concertarem-se os diversos interesses sob o influxo de técnicas que privilegiam a consensualidade. Amplia-se o leque de atividades da Administração estruturadas em pautas mais próximas ao direito privado, bem como surgem novas figuras a desenvolver missões estatais sujeitas a estruturas de direito privado, buscando ser expressamente inseridas em sua atuação em um regime de que não consagre prerrogativas de império.

Em uma suma (que, obviamente, não desconhece a vastidão das questões relacionadas aos temas acima), trata-se de "flexibilizar" a atuação administrativa, de modo a dotar-lhe de instrumental suficiente fluído para perseguir seus novos objetivos. Apenas com pretensão

\footnotetext{
${ }^{127}$ QUADROS, Fausto.Op. cit., p. 8.

128 Sobre essa acepção ampla, que abrange uma variedade de técnicas que implicam no resultado: redução do Estado, consulte-se Maria Sylvia Zanella DI PIETRO (in Parcerias..., p. 15-18).

${ }^{129}$ Relacionando os temas consulte-se Maria Sylvia Zanella DI PIETRO (Ibidem, p. 28-31). Aliás, neste trecho inúmeras tendências evidenciadas ao longo do presente estudo encontram-se relacionadas ao princípio da subsidiariedade, pelo quê se recomenda a passagem para aprofundamento do tema.
} 
expositiva essa é a tendência ora verificada (o que, à obviedade, enseja riscos bastante graves de abuso por parte do mau administrador de uma já denunciada fuga para o direito privado). Cumpre encarecer, que essa tendência opera importantes transformações na relação entre cidadão e Administração, modulando a função administrativa de modo distinto.

Visto isto, importa analisar a tendência a se afirmar uma nova categoria como unificadora da função administrativa, que supera a noção de poder de polícia (tipicamente liberal) e a noção de serviço público (típica do Estado Social). Eis o contexto em que surge a chamada função regulatória.

Nesta linha, o termo regulação ${ }^{130}$ vem sendo posto como a noção unificadora do Direito Administrativo atual, não sendo ele redutível às noções de poder de polícia e de serviço público que a antecederam. Aponta-se que a chamada regulação é um fenômeno novo, que promove a síntese das noções que lhe eram anteriores, contudo, não se identificando de modo direto com nenhuma delas. A regulação seria, então, a categoria orientada a explicar (unificar) o modo de atuação da Administração diante de um mundo complexo (contudo, sem ainda estar definida de um modo preciso). Sobre o tema, anota Calixto SALOMÃO FILHO:

\begin{abstract}
No sistema brasileiro jamais houve tentativa de formulação de uma teoria geral da regulação. A razão para tanto é jurídica e simples. Trata-se da tradicional concepção do Estado como agente de duas funções diametralmente opostas: a ingerência direta na vida econômica e a mera fiscalização dos particulares. A prestação de serviços públicos, de um lado, e a vigilância do mercado, através do poder de polícia, de outro, sempre representaram para os administrativistas a totalidade das funções que o Estado poderia exercer. Em um mundo de dicotomia entre a esfera privada e a estatal não havia por razão para descer da precisão de tal análise. ${ }^{131-132-133}$
\end{abstract}

Com efeito, a separação estanque da atuação do Estado em dois campos (intervenção sobre o domínio privado e serviço público) não rendia ensejo ao surgimento de qualquer categoria de síntese.

\footnotetext{
${ }^{130}$ O termo será explicitado com minúcia no correr da exposição.

${ }^{131}$ SALOMÃO FILHO, Calixto. Regulação da Atividade Econômica (princípios e fundamentos jurídicos), São Paulo: Malheiros, 2001, p. 12.

${ }^{132}$ A exposição adotada por Marçal JUSTEN FILHO em seu Curso de Direito Administrativo dá a crer que o autor adota um conceito autônomo de regulação, não se confundindo ela com poder de polícia e serviço público, sendo cada uma dessas formas de atuação objeto de trato específico. Outro doutrinador que defende expressamente a existência de uma função regulatória com foros de autonomia em relação às outras formas de atuar do Estado é Diogo de Figueiredo MOREIRA NETO. Op. cit., p. 107-113.

${ }^{133} \mathrm{Na}$ doutrina estrangeira, Agustín GORDILLO dedica atenção especial à "La Regulación Económica y Social", tratando-a como categoria dotada de autonomia, inclusive, perpassando a noção de poder de polícia (in Tratado de Derecho Administrativo, tomo 2, 5. ed. Belo Horizonte: Del Rey, 2003, p. VII 1-VII 29.)
} 
As alterações postas pela atual conjuntura imporiam a reordenação profunda (mesmo ao nível das categorias aglutinantes) do modelo jurídico destinado a cuidar da relação cidadão/Administração.

O que vem se advogando, com estribo nas alterações já vistas (ainda que de modo superficial), é a inadequação do ferramental jurídico dos modelos anteriores dar conta de explicar toda a gama de manifestações presentes nos dias de hoje. Anota sobre essa necessária revisão de paradigmas do Direito Público, dissertando especificamente acerca da regulação, Floriano Peixoto de Azevedo MARQUES NETO:

\begin{abstract}
Esta transformação, por óbvio, não se refere apenas à modificação do papel do Estado. Reflete-se também numa profunda transformação no modelo jurídico correspondente à estruturação desse Estado. (...) podemos verificar que vários pilares do juspublicismo estão hoje postos à prova. Dentre tantos fatores que leva a essa constatação, o principal deles parece ser justamente a relação que o Estado é obrigado a travar com os diversos setores econômicos e sociais. Confrontado com atores privados cada vez mais fortes economicamente e com grupos cada vez mais articulados socialmente, o Estado perde, crescentemente, seu caráter de precedência e de supremacia nas relações sociais.(...) Se assumem as agências, hoje, um papel central no Direito Público é porque suas características e seus pressupostos se mostram bastante aderentes àquelas transformações por que, dissemos, passam o Direito e o Estado Modernos. $^{134}$
\end{abstract}

Complementa o autor citado seu pensamento em outra passagem (apenas com uma distinção de nomenclatura acerca do Estado Pós Social chamado de "republicizado") ao anotar expressamente que é a regulação o núcleo do atual modelo de Estado ("função de regulação que entendemos constituir o núcleo do Estado repuplicizado." ${ }^{135}$ ).

Cumpre assinalar, então, que a atividade dita de regulação passa a tomar para si a missão de dar respostas aos desafios que se põe ao Estado e colocam em causa as concepções tradicionais do direito administrativo, o que lhe reserva foros de novidade, como bem demonstram as manifestações doutrinárias que dão trato autônomo à matéria. Sobre essa identificação de regulação como novo tipo de atuação (ainda que sem romper com o passado), manifesta-se Maria Sylvia Zanella DI PIETRO: “Todas essas características e tendências permitem falar da regulação como novo tipo de direito, caracterizado como sendo negociado, flexível indicativo. Porém, é um direito que convive com as formas tradicionais de produção

\footnotetext{
${ }^{134}$ MARQUES NETO, Floriano Peixoto de Azevedo. A Nova Regulação Estatal e as Agências Independentes. SUNDFELD. Carlos Ari (coord.) Direito Administrativo Econômico. São Paulo: Malheiros, 2002, p. 79-81. ${ }^{135}$ Ibidem, p. 198.
} 
legislativa, que apresentam o já mencionado caráter de imperatividade, generalidade, abstração."136

É, pois, justamente uma noção que busca enfrentar tais desafios, e sistematizar o modo de atuação em torno de si. É o esforço que parece vem sendo feito na doutrina nacional a respeito do tema havendo, todavia, ainda grande intranqüilidade acerca do assunto.

O que importa reter é a inegável tendência de apresentar-se a função reguladora como uma nova forma de atuar da Administração especialmente concebida para dar respostas aos desafios postos pelos dias atuais. ${ }^{137}$ Frise-se que esta função não é uma fratura com o longo processo de sedimentação de garantias que caracteriza o Direito Administrativo e, sim, busca abeberar-se destas fontes para dar resposta às complexidades da vida atual. Cuida-se de uma evolução natural e não de uma ruptura abrupta.

A noção de regulação (que se insinua como categoria unificadora do Direito Administrativo dos dias de hoje) busca sintetizar modos de atuação indireta por parte do Estado, respeitando espaços privados, com a necessidade de atuação estatal para promover certos valores por meio de uma série de atividades. Ou seja, sofre influxos da idéia liberal de poder de polícia, bem como da lógica interventiva, do Estado Social; sem reduzir-se perfeitamente a nenhuma delas e agregando novas características como, por exemplo, um dever de eficiência.

Sem prejuízo da análise feita adiante do sentido preciso da regulação (em especial diante do marco constitucional brasileiro), é de se vincar desde logo, em se analisando um plano de perspectiva histórica, que é esta noção que vem ocupando boa parte da doutrina, como espaço apto a dar resposta aos desafios dos tempos atuais.

No limite, como faz Marçal JUSTEN FILHO (estribado em doutrina de Giandomenico MAJONE), a emergência da idéia de regulação, dá ensejo ao surgimento de um novo tipo de Estado, chamado justamente de "Regulador". Sendo que as características desse modelo novo (que ora está-se a chamar de Pós-Social) identificam-se com as apontadas acima,

\footnotetext{
${ }^{136}$ Limites da função reguladora das agências diante do princípio da legalidade. Maria Sylvia Zanella DI PIETRO (coord.). Direito Regulatório. Temas Polêmicos. Belo Horizonte: Fórum, 2003, p. 49.

${ }^{137}$ Neste sentido manifesta-se Santiago Muñoz MACHADO que expressamente afirma a autonomia da função de regulação, relacionando-a com o momento atual: "Explicaremos ahora que es lo nuevo en el modo de intervenir los poderes públicos en la economía y la sociedad que se ha consolidado en Europa al final del milenio. El conjunto de sus objectivos y decisiones ha dado en agruparse en la llamada función de regulación, considerada por algunos tan característica del estado de nuestro tiempo que no han dudado en denominar a éste 'Estado Regulador'." (Op. cit., p. 1172.)
} 
especialmente na necessidade de se rearticular a relação público/privado, buscando uma maior efetividade na implementação das missões reservadas ao Estado. ${ }^{138}$

Sobre este influxo, é que se estar a repensar a dinâmica da atividade administrativa, acrescendo em importância os esquemas (fundados em uma lógica procedimental e plural) dotados de flexibilidade, capazes de dar respostas às demandas fracionadas postas pela ordem social atual. Mais ainda, tal atuação deve levar em conta a necessidade de se articular a relação entre sociedade e Estado do modo diverso dos concebidos pelo Estado Liberal e Social.

Ao fim desse breve escorço - que, insista-se, não pretende exaurir a matéria e sim contextualizar as discussões postas - duas observações se fazem importantes.

A uma, o momento atual é sim de incertezas, não tendo emergido com clareza o que resultará da síntese dessas diversas tendências. ${ }^{139}$ A duas, o legado do Estado Liberal, tendente a afirmar a necessidade de respeito ao cidadão, e o legado do Estado Social, que impõe a necessidade de a ordem pública agir em prol da promoção da sociedade, estão salvaguardados. Não importa o resultado da evolução, essas notas estão plasmadas na Constituição e representam a síntese da longa evolução do Estado de Direito até os dias de hoje não podendo ser ignoradas. Qualquer análise do tema deve partir dessa premissa, sob pena de grave subversão dos valores mais comezinhos da ordem jurídica brasileira.

\subsection{SÍNTESE CRÍTICA DA EVOLUÇÃO DO ESTADO (E DA FUNÇÃO ADMINISTRATIVA) À LUZ DOS PRESSUPOSTOS ATUAIS - UM NOVO MODELO DE RACIONALIDADE}

Sinteticamente, a contemporaneidade se caracteriza pela reavaliação do Estado Social, no sentido de se buscar qual é o ponto ideal na intervenção estatal (o que leva a óbvios questionamentos acerca da Administração e do direito administrativo). Com efeito, a

\footnotetext{
138 Especificamente sobre esse ponto, nada obstante ele tangenciar outros trabalhos deste notável jurista, consultar: JUSTEN FILHO, Marçal. Direito Regulatório. GUIMARÃES, Edgar (coord.) Cenários do Direito Administrativo - Estudos em Homenagem ao Professor Romeu Felipe Bacellar Filho, Belo Horizonte: Fórum, 2004, p. 349-379.

${ }^{139}$ Novamente socorre-se de doutrina de Maria Sylvia Zanella DI PIETRO: "Difícil é qualificar o período atual, à semelhança do que foi feito em relação aos períodos anteriores; poder-se-ia falar em periodo pós-moderno, como querem alguns, ou período neoliberal, como querem outros. A dificuldade está em que a fase é, sem dúvida de transição, de busca de uma definição mais precisa. Existe apenas a coincidência de que é preciso buscar uma reforma do Estado, como decorrência da crise financeira que toma conta do mundo, da globalização, do neoliberalismo, da ineficiência na prestação de serviços públicos, da corrupção, dentre tantas justificativas comumente apontadas." (In Limites..., p. 44.)
} 
discussão contemporânea na teoria do Estado (que se faz sentir em todas as quadras do direito) diz com a avaliação das dimensões do Estado e da sociedade, tomando o seu interrelacionamento sobre novas pautas lógicas. É a eterna disputa acerca da articulação entre público e privado que está em causa, tocando o núcleo do direito administrativo e a sua racionalidade.

Desde um ponto de vista das transformações mais tangíveis, que a reavaliação do Estado Social põe em evidência, está o movimento de redução da participação do Estado no setor econômico e a assunção de um papel de "regulador" dos espaços sociais (usualmente tratado por privatização). Tais tendências não são simples e levam à reavaliação de uma série de categorias jurídicas caras ao direito administrativo, parece mesmo disputar-se acerca da categoria estruturante do direito administrativo. Neste sentido é que vem sendo utilizada a nomenclatura "regulação" como uma síntese da noção de poder de polícia e serviço público. Embora o sentido da regulação supere as categorias anteriores, em seu bojo se expressam preocupações acerca do direito dos cidadãos e da autoridade do Estado, bem como a garantia de prestações à sociedade.

Em que pese, entretanto, ser a manifestação mais concreta da contemporaneidade (no que toca ao Estado, a Administração e o Direito Administrativo) a redução da participação do Estado no domínio econômico (ao menos sobre o aspecto direto), há uma mudança bastante mais profunda acerca da própria racionalidade de hoje.

É, portanto, reducionista analisar o tema apenas por meio de suas manifestações mais explícitas, sendo de todo pertinente averiguar os elementos subjacentes à contemporaneidade referendando o método que se busca seguir, posiciona-se Odete MEDAUAR: "Torna-se fundamental, portanto, indagação a respeito da natureza, função e fim do Estado, o que envolve a questão da estrutura de valores dentro dos quais a vida pública será conduzida; tal indagação diz respeito também ao efetivo exercício da autoridade pública, sobretudo a administrativa, na realização destes valores." 140

Neste esforço de determinação do que vem afinal se alterando na figura do Estado, ao menos em relação às suas linhas clássicas, em um plano mais geral (ao nível da racionalidade do Estado e sua manifestação) pode-se valer dos elementos postos em evidência por Jacques

\footnotetext{
${ }^{140}$ MEDAUAR, Odete. Op. cit., p. 77.
} 
CHEVALLIER em texto no qual se propõe a analisar as características da pós-modernidade, em oposição as da modernidade. ${ }^{141}$

O pensamento do autor francês, parte da investigação acerca do conteúdo do que tem se chamado de pós-modernidade indagando se este período implica ruptura com a modernidade ou o exacerbamento de suas características.(adiante-se, desde já, que se promove síntese entre as duas tendências). Para responder à indagação, o referido autor arrola as características da modernidade, que manifestamente estão presentes na formulação clássica do direito administrativo.

Em relação à modernidade, em linhas gerais afirma o autor francês, que o seu domínio é o (a) da afirmação da razão (que implica na adoção de regras e modelos universais e crença de que as normas devem ser pré-estabelecidas) e (b) da afirmação do individualismo (que levou à construção do modelo de Estado ao redor do homem e a difusão deste modelo pelo ocidente).

O direito característico da modernidade é reflexo desta concepção racional e individualista, mas também é um importante propulsor dos valores subjacentes ao período, é ao mesmo tempo efeito e causa do ideário moderno ("Le droit est donc à la fois l'expression e le vecteur de la modernitê"). ${ }^{142}$

Acerca deste modelo jurídico moderno, podem ser indicadas algumas características de relevo, tais como: direito como manifestação mesmo da razão; caráter de ordem, sistematicidade; transcendência do humano; manutenção dos direitos individuais (anteriores à sua declaração pelo Estado); elemento de justiça e progresso (como parte de uma ordem natural). Sintetiza Jacques CHEVALLIER o modelo mediante a seguinte fórmula: "La societé moderne repose ainsi sur une confiance absolue placée dans le droit, qui conduit au fétichisme de la regle: la norme juridique tend à être prise pour la réalité même, capare de faire advenir ce qu'elle énonce; et le passage para la forme juridiquecen vient à constituer la garantie suprême." 143 Ou, na síntese de Marçal JUSTEN FILHO: "No âmbito do direito, o pensamento típico da 'modernidade' propunha a organização piramidal da ordem jurídica e a sistematicidade, a completude e a ausência de contradições do direito. Imaginava-se possível

\footnotetext{
${ }^{141}$ CHEVALLIER, Jacques. Vers um droit post-moderne? Les transformations de la régulation juridique, in Revue de droit public. n. 3, 1998, p. 659-690. É com base neste texto que está a se expor as peculiaridades da pós-modernidade, em especial em relação ao direito, destacando sua racionalidade.

${ }^{142}$ Ibidem, p. 664.

${ }^{143}$ Ibidem, p. 668.
} 
produzir, por meio do direito, uma revolução social, que gerasse a integração e o bem estar generalizados." 144

Analisando a crise em relação ao modelo moderno (resultado da onda liberal), afirma o autor francês que (destacando o que já foi visto) ela se inicia com o advento do "Estado Providência" (i.e. com o ora chamado Estado Social) que, justamente, leva à perda dos elementos sistematicidade, generalidade e estabilidade usualmente associados ao direito e configuradores de sua identidade.

Com efeito, analisando as alterações procedidas em relação ao modelo, pode-se dizer que a crise maior é a perda do referencial de transcendência do direito que não é mais visto como um produto da razão (crise plus profonde de croyances) e sim como mera técnica de gestão social gerado pela tensão do jogo político e social. Eis, em última instancia, a matéria de essência das transformações evidenciadas que estão subjacentes ao movimento que conduz à afirmação da regulação.

Não apenas o elemento racional é posto em causa, há vívidas críticas à faceta individualista da modernidade. Em especial, tais críticas conduzem ao surgimento de direitos sociais e a luta por uma igualdade que não se esgote no formal, propiciando reais condições de isonomia. Legitimado, pois, está o Estado para agir na esfera individual, sendo a vida social assunto de Estado.

Contudo, como Jacques CHEVALLIER assinala em interessante metáfora, o Estado Social (Providência) é um colosso com pés de barro - "le droi et partout, mais aussi plus vulnérable" - ou seja, não foi o modelo capaz de gerar avanços, vindo mesmo a levar à estagnação da sociedade gerando malefícios graves. É essa ausência de paradigma que é a marca da pós-modernidade.

Esse é o dilema da pós-modernidade: suplantou-se a racionalidade moderna sem, todavia, firmar um modelo capaz de substituí-lo, criando uma vacância em relação à ordenação da vida social. Nesse pano de fundo, é que cumpre analisar a contemporaneidade, esmiuçando suas características em face das atuações do Estado.

Para a compreensão do tema, o professor de Paris busca promover uma síntese analisando os elementos que são apreensíveis, tendo em atenção a pós-modernidade como ruptura com a modernidade e como exacerbamento da modernidade (hiper-modernidade, no

\footnotetext{
${ }^{144}$ JUSTEN FILHO, Marçal. Curso..., p. 14.
} 
sentido de um radical retorno aos seus valores essenciais). $\mathrm{O}$ pensamento do autor analisa o atual momento como síntese dessas duas tendências, apresentando características de ambos os modelos (havendo entre eles uma nítida inter-relação).

Como características gerais, no que toca a ele ser uma oposição à modernidade, aponta o autor a complexidade e a flexibilidade como seus vetores fundamentais.

A complexidade caracteriza-se pela multicidade de normas que regulam a conduta e também pela diversidade de manifestações do fenômeno jurídico (que se chega a comparar à escola Barroca, pródiga em exacerbar os adornos). Pode-se dizer que nestes termos esta dimensão implica em uma nova forma de "conhecer o direito", não mais redutível aos pressupostos da modernidade.

A abordagem apenas não tem como dialogar com as características dos tempos atuais (aliás, muitas das controvérsias jurídicas atuais são reflexo da tentativa de explicar esse ambiente complexo com um ferramental de inspiração moderna).

Uma Administração a quem cumpre estruturar o futuro em vista de uma multiplicidade de interesses e desafiada por um espaço jurídico global deve buscar novos referenciais de atuação. Novamente trazendo a síntese de Marçal JUSTEN FILHO:

\begin{abstract}
A pós-modernidade envolve crises em todas as instituições sociais. Também o Estado pós-moderno é um Estado em crise permanente. Não apresenta uma face estável e se encontra em permanente modificação. As propostas de alteração nem são implementadas e já estão sendo substituídas por outras. O mesmo se passa com o próprio direito. As instituições políticas e jurídicas adquirem as mesmas características do espetáculo (entretenimento) e da moda. ${ }^{145}$
\end{abstract}

A flexibilidade é representada por um manifesto pragmatismo e pelo abandono dos esquemas clássicos (lógica dual preceito/sanção) em detrimento de estruturas que se importam mais com o atingimento de determinados objetivos, valendo-se de termos vagos e consagrando valores, ao invés de fórmulas prévias de atuação (regras). Ou seja, as formas jurídicas de modo algum são cerradas, havendo grande enriquecimento do espaço jurídico. Em relação ao tema pode-se dizer que a flexibilidade implica em um novo modo de "atuar" o direito.

Dentre as características específicas que podem ser associadas à complexidade, esmiúça Jacques CHEVALLIER: (i) pluralismo (especialmente quebrando com a centralidade da ordem estatal, monismo) que se espraia por todos os vértices do fenômeno jurídico -

\footnotetext{
${ }^{145}$ Ibidem, p. 15.
} 
produção das normas, sua inter-relação, adjudicação de conflitos, etc. $\mathrm{O}$ direito (i.e. a regulação da vida social) passa a ser produto de uma rede de vários agentes, importando destacar que a regulação não incumbe mais, apenas ao Estado; (ii) aumento da consensualidade como legitimadora da eficácia da normatividade (o que pressupõe um papel ativo dos cidadãos como interlocutores deste processo de negociação). Ou seja, diante de um ambiente complexo investe-se na redução das inseguranças por meio da adoção de esquemas negociais, onde as partes definem o conteúdo e extensão dos seus direitos de modo a precaverem-se da complexidade.

Ao seu turno, a flexibilidade, ínsita à pós-modernidade, se caracteriza pelas seguintes peculiaridades em relação à atuação do Estado: (i) suavidade, no sentido que se buscam normas que não sejam impositivas e sim indutivas, deixam-se de lado soluções imperativas para fazer valer soluções de adesão, inclusive, reconhece-se que o poder público deve, cada vez mais, ombrear-se ao particular (em suma, manifesta-se o fenômeno da regulação que consiste na adoção dos mais variados meios para atingir os fins buscados, sempre privilegiando soluções não impositivas); adaptabilidade, sendo que a regulação jurídica não se funda mais em uma razão a priori e não é mais constituída por elementos prontos e acabados (imutáveis), sendo construída procedimentalmente, as soluções jurídicas passam a ser transitórias e formuladas com efetiva base nos fatos experimentados, vige uma idéia de experimentação acerca da solução adequada a ser tomada, rompendo-se com a estatuição de comandos definitivos, prontos e acabados.

Vistos os elementos que decorrem de uma concepção da pós-modernidade como ruptura com a modernidade, importa assinalar quais as características atuais que podem ser vistas como uma volta a certos valores da modernidade. Neste sentido, destaca o autor francês os seguintes elementos. Primeiramente, e a racionalidade, embora não haja uma lógica previamente reconhecida ao direito, não há ruptura absoluta com os predicados da razão, esta se caracteriza por ser uma "razão prática". Essencialmente, investe-se em uma melhor estruturação normativa e em controles efetivos, bem como na harmonização de interesses díspares. Buscam-se textos concisos e estáveis, inclusive valendo-se dos ideais da codificação (micro-sistemas). Outro ponto bastante importante é aludir a uma razão procedimental, especialmente calcada em uma legitimação técnica. Com efeito, a pós-modernidade não rompe em absoluto com a razão, apenas muda o tônus em relação a ela. 
A segunda característica que denota a revalorização dos elementos de segurança da modernidade diz com a pan-juridicização, havendo o incremento exponencial da regulação jurídica que passa a alcançar os mais diversos quadrantes da vida social. Há um vertiginoso incremento da regulação jurídica da vida social o que demonstra que a pós-modernidade longe está de ser a morte do direito.

Por fim, há um retorno ao subjetivismo, a exemplo de outras características da modernidade o sujeito novamente é posto em voga. Há uma "absolutização do eu" segundo o autor, que pode ser sentida, por exemplo, no método de trabalho afeito aos direitos fundamentais. As pessoas, mais e mais, estão cientes de titularizarem direitos e cada vez mais os exigem, impondo a necessidade de atuação do Estado (é o que se percebe, v.g. com o sucesso da defesa do consumidor).

A síntese do pensamento de Jacques CHEVALLIER (pontuada por outras referências complementares) tem por escopo buscar explicitar as principais linhas que compõe a razão da contemporaneidade, partindo da compreensão do próprio sentido das alterações experimentadas, superando uma visão que parta apenas das conseqüências e não das causas. Visto de modo expositivo a evolução do Estado, deve se meditar sobre a própria racionalidade de sua atuação hodiernamente. É à luz dessa "racionalidade" que se busca conceber o Direito Administrativo dos tempos de hoje. 


\section{REGULAÇÃO - CONTEXTO E CARACTERÍSTICAS}

Como anteriormente anotado, os desafios dos dias presentes conduzem ao questionamento do Direito Administrativo, levando à necessidade de se repensar as categorias essenciais sobre as quais se desenvolve a relação Estado/cidadão. As alterações sentidas no último período referentes à evolução deste ramo do Direito lançam uma grande carga de novidades a serem enfrentadas. É esse o contexto da regulação, em que ela se insinua como categoria apta a unificar ao redor de um conceito as alterações havidas no Direito Administrativo sem, entretanto, desprezar outras formas de manifestação do agir administrativo.

Com didatismo, a noção de regulação não é criada no vácuo e sim representa uma linha de continuidade em relação às categorias antes cunhadas ao longo da evolução do Estado. Ela caracteriza uma síntese das noções liberais e sociais, ao propugnar pela necessidade de reconhecer o papel dos particulares na promoção do bem estar sem romper, todavia, com o compromisso do Estado Social de impor um dever de atuação do Poder Público no sentido de garantir as condições de desenvolvimento da sociedade.

Sobre um certo sentido, o conceito de regulação supera por meio de uma síntese as matrizes anteriores, mantendo o que cada uma delas tinha de essencial, agregando, contudo, certas particularidades como uma especial preocupação com a implementação das normas, i.e. com a efetiva transformação do mundo do ser. ${ }^{146}$

Embora a noção de regulação tenha, originalmente, identidade com um conceito eminentemente econômico (a atuação do Estado sobre os mercados para corrigir as sua falhas estruturais ${ }^{147}$ ), é fato que ela incorporou em seu bojo missões que vão muito além da mera

\footnotetext{
${ }^{146}$ Essa nota finalística é destaca, dentre outros, por Alexandre Santos de ARAGÃO, aos afirmar que as estratégias regulatórias contêm: “(...) preocupações finalísticas (por exemplo, o desenvolvimento econômico, a competitividade externa) que pressupõem atuações positivas e não meramente negativas das autoridades públicas." (in Agências reguladoras e a Evolução do Direito Administrativo Econômico. 2. ed. Rio de Janeiro: Forense, 2003, p. 28.)

${ }^{147}$ Tradicionalmente, e de modo sintético, as falhas de mercado apontadas são: (i) assimetria de informação entre agentes econômicos, o que implica na impossibilidade de uma das partes conhecer com precisão informações necessárias à adoção de um determinado comportamento; (ii) existência de poder econômico, que possibilita ao seu detentor poder não se submeter as regras do mercado, passando ele a ditar de maneira autônoma em relação a algum fator de produção; (iii) externalidades que representam a existência de certos custos havidos para a produção de algo não serem imputados a quem está a produzir, onerando terceiros, é o exemplo típico da poluição que onera a sociedade como um todo e (iv) bens coletivos que são aqueles que devem ter acesso amplo garantido, não se submetendo a uma lógica de exclusão (como os bens particulares) e cuja produção não é
} 
garantia do funcionamento regular da economia pela correção de defeitos estruturais nos mercados. Neste sentido, emerge a chamada regulação social que, justamente, incorpora em seu bojo missões outras que não apenas a garantia do funcionamento hígido dos mercados (v.g. tutelando o meio ambiente, os trabalhadores, os consumidores e outros).

É no contexto amplo da privatização ${ }^{148}$ (tomado o vocábulo de modo genérico, isto é, alcançando toda a forma de redução do aparato estatal) que toma corpo a chamada regulação, como meio de propiciar que os particulares tenham garantidos os seus direitos mais elementares, mesmo na ausência de atuação direta do Estado. ${ }^{149}$

É quando se adota em larga medida (por conta dos fatores já mencionados, em especial, a crise do Estado Social) esquemas de redução do aparato estatal, que se populariza a idéia de regulação como forma de explicar o novo modo de inter-relacionamento do Estado com a sociedade em vista de um ambiente em que o Estado não mais se faz presente de modo direto. Como anota Vital MOREIRA sobre essa tendência (ressalvada a divergência de nomenclatura):

A década de oitenta foi marcada pela emergência das orientações privatizadoras e liberalizadoras. A palavra de ordem foi a retirada do Estado da área econômica, a liberalização dos mercados, a abertura à concorrência e ao mercado. Com efeito, desde o final dos anos setenta, começou a manifestar-se um movimento, com origem nos Estados Unidos e na Grã-Bretanha, de redução do papel do Estado na economia e de revalorização do papel do mercado e da concorrência. Designado genericamente como movimento de 'desregulação', ele abarca três vertentes distintas: a privatização de empresas públicas ou de participações públicas em empresas mistas; a liberalização de actividades e setores econômicos, até então reservados para o sector público, ou pelo menos dependentes de concessão ou autorização pública (como era o caso das 'public utilities', incluindo a electricidade, a água, o gás, os transportes aéreos e ferroviários, as comunicações, a rádio e a televisão); a desregulação propriamente dita, que consiste no

incentivada pelo mercado. Para aprofundar o tema, indique-se Fábio NUSDEO. Curso de economia. 3. ed. São Paulo: RT, 2001, p. 138-167.

${ }^{148}$ Como anota Paulo OTERO, privatização é termo polissêmico. O publicista português arrola cinco significados distintos para o termo: (i) redução ou supressão da intervenção reguladora do Estado sobre certo setor econômico (desregulamentação ou auto-regulação); (ii) adoção por empresas estatais de métodos de atuação privados (como na expressão "fuga para o direito privado"); (iii) transformação de uma personalidade jurídica de "direito público" para de "direito privado"; (iv) atribuição da gestão de atividades e/ou patrimônio público por particulares por meio de expedientes de delegação ( $v . g$. a concessão) e (v) transferência de capital de sociedades controladas pelo Estado para particulares. (in Privatizações, Reprivatizações e Transferências de Participações Sociais no Interior do Sector Público. Coimbra: Coimbra, 1999, p. 14-15.)

149 Neste sentido, expressamente manifesta-se Maria Sylvia Zanella DI PIETRO: "No direito brasileiro, o vocábulo regulação surgiu com o movimento de Reforma do Estado, especialmente quando, em decorrência da privatização de empresas estatais e da introdução da competição entre concessionárias na prestação de serviços públicos, entendeu-se necessários 'regular' as atividades objeto de concessão a empresas privadas, para assegurar regularidade na prestação dos serviços e o funcionamento equilibrado da concorrência." (in Limites..., p. 28.) 
aligeiramento ou eliminação do controlo público sobre a produção e o mercado de numerosas indústrias. 150

Esse movimento, que teve início ainda na década de oitenta em países da common law, espraiou-se para a Europa continental e depois, no início da década de noventa, chega até o Brasil, ${ }^{151-152}$ preservando em sua essência, qual seja, redução do aparato estatal (valendo-se de diversas técnicas para tanto). ${ }^{153}$

É, justamente, esse momento histórico que dá início a considerações doutrinárias acerca da regulação, conceito estranho ao direito brasileiro até a onda de privatizações. ${ }^{154}$ Como afirma sinteticamente Marçal JUSTEN FILHO: “A contrapartida da redução da intervenção estatal consiste no predomínio de funções regulatórias."155-156 Com efeito a

\footnotetext{
${ }^{150}$ MOREIRA, Vital. In Auto-regulação profissional e administração pública. Almedina: Coimbra, 1997, p. 43.

${ }^{151}$ Anotam sobre o processo no Brasil Armando Castelar PINHEIRO e Jairo SADDI: "O Brasil não tem ficado de fora dessas tendências. Em especial, muitas das reformas empreendidas desde a década de 1980 têm sido caracterizadas pela substituição de um Estado empresário por outro que se preocupa mais em regular o setor privado. Por trás dessas reformas está a visão de que o mercado é mais eficiente que o Estado em definir a alocação de recursos e produzir. Elas são, também, uma reação à constatação de que a intensa intervenção estatal que caracterizou a economia brasileira durante a maior parte do século XX foi marcada por muitos problemas" (in Direito, Economia e Mercados. Rio de Janeiro: Elsevier, 2005, p. 253-254.)

${ }^{152}$ Sobre um viés cético acerca do movimento, dentre tantos outros, anota Paulo Roberto Ferreira MOTTA: "Como não poderia deixar de ser no final da década de 80 e início da de noventa, do século passado, os ecos da retumbante vitória não tardariam a chegar ao restante do globo, pois privatizar e reformar eram, e são, as palavras de ordem em todas as nações do mundo. Nos países de capitalismo periféricos, os projetos privatizantes são uma constante. O processo de privatização, notadamente na América Latina, ao contrário do que ocorre em solo europeu não visa uma melhor qualidade na prestação dos serviços públicos. É, fundamentalmente, o método utilizado pelos governos para fazer frente às exigências de seus credores internacionais no (re)financiamento dos programas de estabilização econômica dos anos de 1990. Serve, também, ao criar desemprego em massa, para debilitar os movimentos sociais adversários do capitalismo. O que se pode notar é que os ganhos dos processos de privatizantes na América Latina são altamente contestáveis e na prática, na maioria das vezes, o que se tem é um câmbio de monopólios, antes estatais, agora particulares, e, no mais das vezes, estrangeiros." (In Agências Reguladoras, Barueri: Manole, 2003, p. 2-3.)

${ }^{153}$ No Brasil esse movimento ficou a cargo de diversas reformas constitucionais e do chamado Programa Nacional de Desestatização, iniciado com a Lei n. ${ }^{\circ} 8.031 / 90$ que foi substituída pela Lei n. ${ }^{\circ} 9.491 / 97$, segundo esta, em suma, eram objetivos deste movimento: (i) reordenação da posição estratégica do Estado, devolvendo a iniciativa privada atividades indevidamente sobre o seu controle; (ii) reestruturação da economia do setor público; (iii) retomada de investimentos nas empresas transferidas à iniciativa privada; (iv) contribuição para reestruturação do setor privado, melhorando a sua competitividade; (v) concentração das atividades administrativas em setores estratégicos, onde se faça necessária a presença da Administração e (vi) fortalecimento do mercado de capitais. Para uma análise panorâmica acerca da Reforma Administrativa e a "privatização" por ela procedida consulte-se: Caio TÁCITO. Três Momentos da Privatização in Temas de Direito Público (Estudos e Pareceres, v. 3. Rio de Janeiro: Renovar, 2002, p. 61-67.

${ }^{154}$ Neste mesmo sentido, associando expressamente regulação à redução da intervenção direta do Estado na economia, manifesta-se Calixto SALOMÃ̃ FILHO. Op. cit., p. 15.

155 JUSTEN FILHO, Marçal. $O$ direito..., p. 21.

156 Essa identificação da retirada do Estado da atuação direta da ordem econômica com o surgimento das preocupações com a chamada regulação é acompanhada, expressamente, por Maria Sylvia Zanella DI PIETRO (in Limites..., p. 32-33.)
} 
regulação, em sua acepção atual, é fruto do contexto de redução da atuação direta do Estado nos domínios econômicos, refletindo uma troca de orientação em relação aos instrumentos a serem adotados.

Em relação aos fundamentos da regulação, algumas posições são possíveis de serem visualizadas, visando a explicitar a racionalidade a ser adotada diante desse novo contexto.

Vital MOREIRA em sua monografia sobre o tema aponta dois objetivos fundamentais que podem ser vistos na regulação. Uma teoria, denominada do "interesse público" vê como sendo o objetivo primacial da regulação a correção das falhas estruturais dos mercados, com vistas ao atendimento de objetivos socialmente úteis (defesa da concorrência, respeito ao meio ambiente, consumidores). Para esta linha, o fundamento último da atuação indireta do estado sobre os mercados seria a garantia dos interesses públicos eleitos pelo Estado como dignos de serem implementados. Outra linha apontada pelo autor português como dando fundamento à atuação do Estado seria a de proteção das próprias atividades reguladas, de modo a que o Estado as tutelasse por meios de suas ações. ${ }^{157-158}$ É de se mencionar ainda que de passagem, em relação a esta última concepção, que há escolas econômicas que tendem a associar a regulação, sempre, como um produto buscado pelos interessados em seu próprio benefício, de modo que - em última instância - as regras editadas sempre o seriam em benefício dos

\footnotetext{
157 "Na primeira perspectiva - que é a concepção tradicional e prevalecente -, a regulação é o resultado de uma imposição estadual sobre os agentes económicos, em nome de interesses gerais, tal como sucede em relação a toda acção estadual em geral. Na segunda perspectiva, a regulação deriva do próprio interesse dos regulados." (Op. cit., p. 41.)

${ }^{158}$ Adotando classificação um tanto diversa tem-se o pensamento de Calixto SALOMÃO FILHO. Para o professor do Largo de São Francisco a regulação é informada por duas escolas. Uma, também, chamada de Escola do Interesse Público buscaria de fato a implementação de missões públicas para a regulação, em nome da promoção do interesse público. Todavia, o referido autor, identifica essa escola como cingindo a regulação a técnicas de monopolização de atividades pelo Estado, ordenadas em torno da noção de serviço público e adoção do regime jurídico a ele subjacente. Nesta linha, tece o autor severa crítica a essa escola por supor que por meio de suas técnicas é ela incapaz de garantir a promoção de valores socialmente desejáveis, por haver uma incompatibilidade de essência entre o interesse do particular que venha a explorar tais atividades (que limita-se a busca privada do lucro) e o interesse público efetivo. Não seria capaz a regulação (tendo o Estado como titular da atividade) de prever todas as variáveis envolvidas, controlando com efetividade as prestações disponibilizadas à coletividade. Essa escola não seria capaz de promover de fato o interesse público, sendo o Estado submetido ao interesse do particular, em detrimento do atendimento de finalidades públicas (in Teoria..., p. 17-21). Nesse sentido, embora haja identidade de nomenclatura, o pensamento de Calixto SALOMÃO FILHO afasta-se do de Vital MOREIRA, pois, aquele identifica a Escola do Interesse Público com a necessária adoção do regime de serviço Público. A outra linha identificada pelo autor ora em análise seria a "Escola Neoclássica ou Econômica" sendo que esta fundamentar-se-ia (e aqui novamente o pensamento é diverso do de Vital MOREIRA) na correção das falhas de mercado, sem que isso configurasse qualquer interesse público. A regulação neste caso seria um supedâneo do mercado nos setores em que não fosse este capaz de regulamentar com propriedade a atividade. $\mathrm{O}$ autor tece críticas a esta escola por ser mera ficção a possibilidade de artificialmente se reproduzir o mercado e suas condições, bem como por haver objetivos não econômicos a serem alcançados. (Op. cit., p. 21-26.)
} 
favorecidos, o que leva a se preferir soluções de mercado, haja vista a inocuidade das tentativas do Poder Público condicionar a atuação dos privados. Foram concepções desta ordem que influenciaram os movimentos de desregulação norte-americanos, em vista da impossibilidade de o Estado intervir de modo efetivo em algumas atividades, justificando sua retirada de determinadas delas. ${ }^{159}$

Do que importa, todavia, deixar claro é que, independente das concepções econômicas por de trás da regulação, é fato indisputado que ela se instrumentaliza por meios jurídicos (mesmo a mais voraz redução estatal, deve ser mediada pelo direito, quando menos como um instrumento de transição). Com efeito, a intervenção do Estado no domínio econômico se dá, necessariamente, pela via jurídica. Ou seja, filosofias regulatórias distintas para atuar devem contar com suporte jurídico, sendo as características dos modelos em tela, o pressuposto da redução da atuação direta do Estado.

Este pressuposto comum (redutível à idéia ampla de privatização) implica em que possam ser assinaladas algumas características referentes à regulação, decorrentes da configuração de um modelo de Estado dito Regulador.

Retomando a análise de Marçal JUSTEN FILHO acerca do tema, podem ser apresentadas as seguintes características conformadoras em diferentes instâncias de um Estado Regulador: (i) quanto ao âmbito de abrangência das atividades sujeitas ao direito público e ao direito privado, a tônica é da liberalização (privatização); (ii) quanto ao modo de atuação do Estado há a substituição da atuação direta pela indireta; (iii) em relação aos objetivos da regulação nota-se a superação da intervenção regulatória como meio apenas de corrigir falhas de mercado e passa-se a adotá-la com vistas a realizar valores políticos e sociais (regulação social) e (iv) no que tange aos mecanismos da regulação, supera-se um paradigma de normatização estática para mecanismos de disciplina permanente da atividade econômica privada, que são dinâmicos (interessa não só o momento em que se põem as regras, mas

\footnotetext{
${ }^{159}$ Sem prejuízo do rico debate acerca do tema, nesta linha é interessante a menção ao estudo seminal específico de George J. STIGLER. Teoria da Regulação Econômica, MATTOS, Paulo (coord.) Regulação e Democracia. São Paulo: 2004, p. 23-49), professor da Universidade de Chicago e vencedor do Prêmio Nobel de Economia, em 1992. Neste célebre artigo, que rendeu ensejo para uma série de debates, o autor defende, estribado em análise de mercados específicos, de modo central que a regulação configura um custo para as empresas que são estimuladas a buscar a produção de regras que lhes sejam favoráveis, em detrimento da independência de quem produz a regulação - "em regra a regulação é adquirida pela indústria, além de concebida e operada fundamentalmente em seu benefício" (Op. cit., p. 23). Para o autor, o processo político se informa também por uma lógica de mercado, sendo a regulação mais um custo para as empresas sendo os efeitos dessa atuação perniciosos para o resto da sociedade.
} 
também seu efetivo cumprimento, ou seja, com a modificação efetiva do ambiente regulado). ${ }^{160}$

Assim, especificamente, no que tange ao desempenho em concreto da atividade regulatória é de se ver que ela caracteriza uma preferência pela adoção de mecanismos de atuação estatal indiretos ("sobre" o mercado e não "no" mercado, para utilizar a sistematização feita por Eros Roberto GRAU ${ }^{161}$ ), em especial, estabelecendo-se normas e outros estímulos à alteração do comportamento natural dos agentes econômicos. Ainda, é de se dizer que uma das características intimamente associadas à regulação é a busca de efetividade das prescrições postas aos particulares. Não basta apenas prever condutas abstratamente e lhes aquinhoar determinadas sanções (sejam positivas, sejam negativas), é necessário um compromisso com a real alteração do ambiente.

Partindo do mesmo substrato (i.e. da emergência de um Estado dito Regulador) Maria Sylvia Zanella DI PIETRO, estribada em Vital MOREIRA, anota quais são, em seu sentir, as características da regulação, o que vai ao encontro da exposição já levada a efeito: (i) estabelecimento de regras; (ii) controle das atividades privadas (e o sentido da expressão é o forte, definido por Fábio Konder COMPARATO ${ }^{162}$ ) e (iii) finalidade pública, que seria o funcionamento equilibrado do mercado. ${ }^{163}$

Em jeito de síntese, então, pode-se dizer que o contexto no qual a regulação passa a ser objeto de cogitações próprias por parte da doutrina (como categoria nova incapaz de ser completamente explicada pelo ferramental jurídico disponível) é o da redução do tamanho do Estado. As privatizações (em seu sentido mais amplo) são o suposto material que conduzem à emergência da regulação.

Com a retirada do Estado de campos anteriormente por ele ocupados, fez-se necessário conceber novas formas de atuação especialmente destinadas a garantir os objetivos sociais que, até então, buscavam ser concretizados por meio da atuação estatal direta.

E, justamente, as características associadas ao fenômeno da regulação impendem que a relação estabelecida entre o Estado e os novos espaços criados pela redução de seu tamanho

\footnotetext{
160 JUSTEN FILHO, Marçal. In o Direito..., p. 21-25.

${ }^{161}$ GRAU, Eros Roberto. In A Ordem..., p. 133-134.

162 Controle, em seu sentido forte, implica mais do que mera fiscalização, diz com a capacidade mesmo de determinar a conduta de outrem, conforme a lição célebre do referido professor (COMPARATO, Fábio Konder. O poder de controle na sociedade anônima. 3. ed. Rio de Janeiro: Forense, 1983, (em especial, no cap I).

${ }^{163}$ DI PIETRO, Maria Sylvia Zanella. In Limites..., p. 29.
} 
seja explicada apenas com recurso a categorias já conhecidas no Direito Administrativo. Embora o conceito de intervenção já alcançasse manifestações indiretas do Estado sobre o domínio econômico é forçoso reconhecer que a categoria sempre esteve intimamente relacionada à presença efetiva do Estado na economia, por meio de empresas estatais. Quando menos, a atuação indireta era residual e não configurava um paradigma efetivamente levado a cabo pelo Poder Público.

Insista-se, a concretização de objetivos sociais era creditada à atuação do Estado de modo direto sobre o domínio econômico, seguindo a rationale do Estado Social. ${ }^{164}$ E mesmo se concebendo a atuação indireta do Estado (ainda que de modo residual), não se manifestava a preocupação que hoje é externada acerca da efetividade da atuação sobre o domínio econômico. De um certo modo, a presença do Estado na ordem econômica, na qualidade de empresário, tornava latente as discussões acerca da efetividade das normas expedidas para implementar os valores sociais. A simples presença do Estado na economia levava à crença de que o funcionamento dos mercados garantiria o atingimento de pautas socialmente adequadas. Vale dizer, havia a crença que a presença do Estado - ente moral que persegue interesses públicos - garantiria a implementação de pautas sociais.

É com base, pois, neste contexto que emerge a regulação como uma categoria que, mais e mais, se presta a buscar explicar a inter-relação entre Estado e sociedade, tendo por interface a ordem econômica.

\subsection{REGULAÇÃO (CARACTERIZAÇÃO ESTRITA)}

Uma vez definido o contexto em que emerge a regulação é de se precisar o seu conteúdo de modo a dotar o conceito de operacionalidade. ${ }^{165}$

Regulação, anota o grosso da doutrina, é termo impregnado de diversas significações, o que dificulta seu uso. ${ }^{166}$ Seja por ser originalmente estranho ao direito administrativo e que

\footnotetext{
${ }^{164}$ Nesse sentido a orientação de Santiago Muñoz MACHADO: "El estado proprietario ha usado su propria posición dominante como fórmula para orientar los mercados o para condicionar o interferir su funcionamento plenamente libre a las decisiones de los empresarios." (Op. cit., p. 1173.)

165 Não se perca de mira a advertência de Fernando Menezes Dias de ALMEIDA analisando o conceito de regulação: "Visto esse panorama doutrinário, no Brasil, acerca da regulação, percebe-se que efetivamente se está contemplando um fenômeno em plena evolução, captado em ângulos diversos por seus observadores, e ainda não passível de ser objeto de conclusões definitivas." (Teoria da Regulação in Curso de Direito Administrativo Econômico. v. III. São Paulo: Malheiros, 2006, p. 148.)
} 
tem sua adoção primeiramente em outros países, o fato é que a expressão está longe de ser unívoca. Antes de tudo, então, é de se precisar o sentido do termo, evitando indeterminações semânticas absolutamente indesejáveis em se tratando de direito.

Em um primeiro lugar, o termo, por ser derivado do léxico anglo-saxão, causa alguma espécie ao ser introduzido nas línguas latinas. Isto, pois, o termo "regulation" pode vir a ser vertido para o português como "regulamentação" ou "regulação" (derivadas, com escusa da redundância, respectivamente, dos verbos regulamentar e regular). Adota-se o termo regulação (em detrimento de regulamentação), haja vista haver conteúdo preciso associado no direito pátrio ao verbo regulamentar (i.e. a expedição de atos infralegais pelo chefe do executivo a título de fiel cumprimento da lei), sendo que o conceito de "regulation" vai bastante além disso. Nesta linha, apresenta-se uma primeira explicitação do acerca da adoção do vocábulo regulação que visa a apartá-lo do conceito de regulamentação. ${ }^{167-168}$ Regulação é atividade mais ampla do que a mera expedição de comandos infralegais para explicitar o conteúdo da lei, não se confundindo com regulamentação (embora usualmente possa adotar em seu bojo essa técnica de implementação).

Feita essa primeira ressalva terminológica, pode-se buscar uma caracterização mais estrita para o termo. Regulação, mesmo neste sentido já depurado (i.e., diferente de regulamentação), é termo ainda dotado de diversos sentidos, importando, pois, defini-lo para que dúvidas não haja em relação ao seu alcance. Conforme aponta Vital MOREIRA, referência obrigatória neste tema, alude-se a uma ambivalência intrínseca ao conceito de regulação: “O termo 'regulação' é essencialmente ambivalente: por um lado, designa um estado de equilíbrio e de regularidade no funcionamento de um sistema ou mecanismo; por outro lado, aponta para o estabelecimento de regras (regulamentos) a serem observadas num determinado comportamento ou situação, tendo precisamente como objetivo garantir ou repor o equilíbrio e/ou a regularidade do seu funcionamento."169

\footnotetext{
${ }^{166}$ Apenas para breve registro, apontam essa nota, dentre outros: Maria Sylvia Zanella DI PIETRO (in Limites..., p. 27-30), Odete MEDAUAR (Op. cit., p. 252 a 259), Marçal JUSTEN FILHO (O Direito..., p. 15-16), Alexandre Santos de ARAGÃO (Op cit., p. 19) e Eros GRAU (in O Direito..., p. 131;135).

${ }^{167}$ Neste sentido, Odete MEDAUAR (Op. cit. p. 253) e Marçal JUSTEN FILHO (in O Direito..., p. 15-16).

${ }^{168}$ Em sentido diverso, tem-se o magistério de Eros Roberto GRAU: "Como os norte-americanos usam o vocábulo regulation para significar o que designamos 'regulamentação', desregulation para eles, assume o mesmo significado que indicamos ao usa o vocábulo 'regulação'; vale dizer: a desregulation dos norteamericanos está para a regulation assim como, para nós, a 'regulação' está para a regulamentação." (in $\mathrm{O}$ Direito..., p. 131.)
}

${ }^{169}$ MOREIRA, Vital. Op. cit., p. 21. 
Ainda, o referido autor português anota outras disputas acerca da matéria. Quanto à amplitude do conceito, por exemplo, três linhas se apresentam: (i) em sentido amplo é qualquer forma de ingerência (intervenção/atuação ${ }^{170}$ ) do Estado sobre assuntos econômicos; (ii) em um sentido um tanto mais restrito, diz com a intervenção estatal na economia, disciplinando a atuação dos particulares e (iii) e no mais restrito dos sentidos, diz apenas com a estatuição de normas acerca da disciplina privada (o que conforme lição de Eros Roberto GRAU, equivaleria à intervenção por "direção/indução" $\left.{ }^{171}\right) .{ }^{172}$

De outra banda, em relação ao objeto da regulação, pode-se classificá-la em econômica (considerando-se apenas este campo especificamente) e social (que leva em conta pautas éticas que sujeitam o mercado a interesses alheios a ele). ${ }^{173}$

Tendo em mira essas controvérsias, é que importa fixar um conteúdo operacional de regulação, apto a dar conta do tema, ao lume do modelo jurídico brasileiro. Aliás, como anota Maria Sylvia Zanella DI PIETRO, após a utilização do termo no Texto Constitucional de 1988, imperioso buscar dotá-lo de sentido. ${ }^{174}$ Independentemente das controvérsias acerca do tema, a menção constitucional do Estado como agente regulador (CF, art. 174) impõe a necessidade da definição de um sentido juridicamente útil para a expressão.

Primeiramente, importa assinalar qual é a idéia de fundo inerente à regulação. Diversos autores buscam cunhar conceitos de regulação, sendo interessante percorrer o seu pensamento para lhes apontar os traços comuns, de modo a atribuir-se sentido operacional ao termo (tomado em diversos sentidos e, por muitos, sem qualquer tentativa explícita de identificar as suas características fundamentais). ${ }^{175-176}$

\footnotetext{
${ }^{170}$ Está-se a utilizar aqui a terminologia consagrada entre nós por Eros Roberto GRAU, apta a dar conta da estrutura constitucional brasileira, que separa a atuação estatal como manifestação do Estado em domínio próprio (i.e. serviço público) da intervenção, que configura manifestação pública no domínio da iniciativa privada. Ambas as formas estão sujeitas a regimes jurídicos distintos. A duas, contudo, são atividades econômicas em um sentido amplo, na medida em que cuidam da gestão bens escassos. (in A Ordem..., p. 84-85.)

${ }^{171}$ Idem.

${ }^{172}$ MOREIRA, Vital . Op. cit., p. 34-36.

173 Ibidem, p. 37-39.

${ }^{174}$ DI PIETRO, Maria Sylvia Zanella. In Limites, p. 28.

${ }^{175}$ Ainda antes de se proceder ao exame dos conceitos que atualmente vêm se apresentando para regulação é de se anotar que ainda em 1968, Alberto VENÂNCIO FILHO aludia ao que chamava de "Direito Regulamentar Econômico" ferindo temas como a independência deste conceito vis-à-vis uma noção estrita de poder de polícia, legitimação pela técnica, adoção de intervenções de influência, delegação para órgãos reguladores e outros temas dotados da mais alta atualidade (Op. cit., p. 83-88). Isso vem demonstrar a atualidade do pensamento do autor.

${ }^{176}$ Santiago Muñoz MACHADO também destaca que regulação não é de modo algum uma idéia absolutamente novidadeira (Op. cit., p. 1173).
} 
Maria Sylvia Zanella DI PIETRO, após analisar os diversos conceitos arrolados por Vital MOREIRA aponta as seguintes características como integrando a idéia de regulação: (i) estabelecimento de regras de conduta; (ii) controle da atividade privada pelo Estado, equivalendo à idéia de polícia administrativa e (iii) finalidade pública, que seria o estabelecimento equilibrado do mercado. Com base nestes elementos, apresenta a autora o seguinte conceito de regulação: “(...) conjunto de regras de conduta e de controle da atividade privada pelo Estado, com a finalidade de estabelecer o funcionamento equilibrado do mercado". 177

Todavia, mais adiante, a autora apresenta um conceito um tanto quanto mais amplo para abarcar as atividades de titularidade do Estado, bem como ampliando as suas finalidades. Nessa acepção mais ampla, cunha-se o seguinte conceito, dotado de maior abrangência: “(...) regulação constitui-se como o conjunto de regras de conduta e de controle da atividade econômica pública e privada e das atividades sociais não exclusivas do Estado, com a finalidade e proteger o interesse público." ${ }^{178}$

Neste conceito mais amplo estão abrangidas duas notas importantes a serem destacadas em relação ao conceito de regulação: (i) a sua não identificação apenas com as atividades privadas (alcançando agentes que desempenhem serviço público, art. 175 da CF/88 e que promovam a intervenção do Estado no domínio privado, nos termos do art. 173 da CF/88), (ii) bem como a abrangência da regulação à chamada "regulação social".

Marçal JUSTEN FILHO também não se furta a cunhar uma definição explícita de regulação, e o faz nos seguintes termos: "A regulação econômico-social consiste na atividade estatal de intervenção indireta sobre a conduta dos sujeitos públicos e privados, de modo permanente e sistemático, para implementar as políticas de governo e a realização dos direitos fundamentais." ${ }^{179}$ Da análise do conceito visto logo acima com o presente nota-se a sua grande proximidade. Para esse autor, a regulação, obviamente, alcança o âmbito social, ${ }^{180}$ bem como não se exaure na imposição de regras apenas aos particulares, estando abrangidos pelo conceito atores estatais que desempenhem atividade econômica (em sentido amplo, ou seja, abarcando o domínio público).

\footnotetext{
${ }^{177}$ DI PIETRO, Maria Sylvia Zanella. Op. cit., p. 29.

${ }^{178}$ Ibidem, p. 30.

179 JUSTEN FILHO, Marçal. In Curso..., p. 447.

180 "Toda regulação é concomitantemente econômica e social." anota o autor (Idem).
} 
Merece ainda destaque na posição do autor o apelo a concepções de atuação indireta, bem como o seu caráter permanente e sistemático. Sobre esse último aspecto, encarece o autor como nota que peculiariza o fenômeno em vista de outras atuações administrativas:

A regulação se caracteriza pela organização de meios materiais e humanos, com a criação de estruturas administrativas especializadas, visando a desempenho contínuo e racional. A regulação consiste não apenas na produção de normas e atos decisórios, mas na produção ordenada de normas e atos decisórios. Como afirmou SELZNICK, a regulação consiste em um controle permanente e concentrado, exercido por uma autoridade pública sobre atividades dotadas de certo valor social. ${ }^{181}$

Veja-se, que em vista do conceito desse autor, a regulação possui um "plus" em relação a outras manifestações de atuação estatal que se identifica com a necessidade de haver efetividade na regulação, sendo criadas condições de real alteração do comportamento dos sujeitos passivos da regulação em prol de valores sociais. Nota-se, ainda que não aluda o autor taxativamente à expressão, uma idéia de vinculação finalística da regulação. Não basta a atuação passiva do regulador, deve haver uma atuação efetiva capaz de garantir a imposição das condutas desejadas aos regulados. Atrela-se a idéia de regulação à necessidade de os resultados almejados serem alcançados, alterando-se, de fato, o ambiente regulado.

Esta associação explícita entre a regulação e o atingimento dos objetivos a serem perseguidos é destacada, agora de modo mais explícito, também por Tércio Sampaio FERRAZ JÚNIOR, ao introduzir na análise da regulação o princípio da eficiência, manifestando-se nos seguintes termos:

Afinal, o princípio da eficiência tem por característica disciplinar a atividade administrativa nos seus resultados e não apenas na sua consistência interna (legalidade estrita, moralidade, impessoalidade). Por assim dizer, é um princípio para fora e não para dentro. Não é um princípio condição mas um princípio fim, isto é, não impõe apenas limites (condição formal de competência) mas impõe resultados (condição material de atuação). ${ }^{182}$

Embora o autor não formule um conceito explícito de regulação (apenas mencionando que esta atividade pressupõe o manejo de poderes quase-legislativos, quase-judiciais e quaseregulamentares), atrela ao desempenho dessas competências a idéia de validação pelos

\footnotetext{
${ }^{181}$ Ibidem, p. 448.

${ }^{182}$ FERRAZ JÚNIOR, Tércio Sampaio. Agências Reguladoras: Legalidade e Constitucionalidade, in Revista Tributária e de Finanças Públicas. São Paulo, n.35, nov./dez. 2000, p. 151.
} 
resultados. ${ }^{183}$ Ainda nessa linha, Diogo de Figueiredo MOREIRA NETO ao curar de um conceito de regulação também apela à eficiência como elemento de caracterização do fenômeno. ${ }^{184}$

Calixto SALOMÃO FILHO, no que tange ao conceito por si formulado, parte da necessidade de uma formulação de uma teoria da regulação no sentido de ser "a contribuição mais útil de um Estado que decide retirar-se da intervenção econômica direta (através da prestação de uma gama bastante variada de serviços) para a sua função de organizador das relações sociais e econômicas e que, por outro lado, reconhece ser para tanto insuficiente o mero e passivo exercício de um poder de polícia sobre os mercados." ${ }^{185}$ Neste sentido, de ser necessário desenvolver uma teoria que esteja apta a dar suporte a um Estado que se pretende "organizador" das relações sociais e econômicas, é que o autor citado vai formular o seu conceito:

a acepção que se pretende atribuir ao ‘termo' regulação, a fim de estudar as concepções ao seu respeito que têm influenciado o sistema brasileiro, é bastante e propositalmente ampla. Engloba toda a forma de organização da atividade econômica através do Estado, seja a intervenção através da concessão de serviço público ou o exercício do poder de polícia. (...) $\mathrm{Na}$ verdade o Estado está ordenando ou regulando a atividade econômica tanto quando concede ao particular a prestação de serviços públicos e regula sua utilização - impondo preços, quantidade produzida etc. - como quando edita regras no exercício de poder de polícia administrativo. É, assim, incorreto formular uma teoria que não analise ou abarque ambas as formas de regulação. ${ }^{186}$

Embora o autor refira de modo explícito apenas a regulação de serviços públicos e, indireta, de atividades particulares, a amplitude emprestada ao conceito no pensamento dele insinua-se ainda mais dilatada. Em última instância, quem tem por missão a "organização das atividades econômicas e sociais" e para tanto em sua atuação "engloba toda a forma de organização da atividade econômica através do Estado" pode mesmo vir a lançar mão de estratégias diretas com vistas a promover esses objetivos. Com efeito, não parece contrário ao conceito trazido pelo autor que, excepcionalmente, haja alguma atuação direta do Estado no mercado com vistas a promover algum interesse público (e que isso caracterize uma forma de regulação). Isto também parece estar abrangido no conceito de regulação trazido por Calixto

\footnotetext{
${ }^{183}$ Ibidem, passim.

${ }^{184}$ MOREIRA NETO, Diogo de Figueiredo. In Mutações do Direito Público. Rio de Janeiro: Renovar, 2006, p. 391-392.

${ }^{185}$ SALOMÃO FILHO, Calixto. Op. cit., p. 14.

${ }^{186}$ Ibidem, p. 15.
} 
SALOMÃO FILHO, desde que se veja a presença no mercado como um meio de transformálo, moldando-o para a produção de resultados socialmente úteis.

Aliás, a evolução do pensamento do autor aponta nesse exato sentido de que a intervenção direta no mercado (por participação na terminologia consagrada por Eros GRAU) é concebível como uma forma de regulação, desde que submetida à persecução de interesses determinados e com vistas a estabelecer valores socialmente úteis. Em estudo posterior, assevera Calixto SALOMÃO FILHO:

\begin{abstract}
É a essa intervenção (ou, se assim se preferir) baseada em princípios institucionais jurídicos, e não em objetivos de política econômica, que ora se dá o nome de regulação no sentido jurídico. Note-se que, exatamente por ser baseada em princípios jurídicos, ela não se faz necessariamente por uma única forma. Não se dá, como nos casos do planejamento estatal clássico ou das soluções puramente de mercado, através de formas únicas (respectivamente, planejamento diretivo com submissão ao regime de serviço público ou do exercício do poder de polícia). Uma intervenção na economia baseada nestes princípios institucionais pode assumir várias formas. É possível por exemplo, que esta se dê de forma coerente através de participação de empresas públicas (muitas vezes ex-monopolistas de direito) em setores pouco desregulamentados ou pouco regulamentados. O papel da empresa estatal, desde que tenha poder no mercado suficiente para tanto, passa então, a ser o de planejador e direcionador de desenvolvimento setorial. A eficiência (aqui no sentido produtivo) da atuação estatal é, também, garantida através da presença de concorrentes (existentes ou potenciais). O papel da concorrência é, aqui, novamente arejar o órgão planejador (no caso o estatal) permitindo o melhor conhecimento da realidade e, eventualmente, a mudança de rumo do planejamento. ${ }^{187}$
\end{abstract}

A presente citação é o quanto basta para que se extraia a contribuição mais original do pensamento do autor, qual seja, a flexibilidade de meios inerentes à racionalidade da regulação permite que se conceba a própria intervenção direta (em casos residuais) como uma técnica possível para o exercício dessa função.

Pode ser que determinadas atuações regulatórias (como o conhecimento preciso do mercado, diminuindo a assimetria de informação entre os agentes econômicos e o regulador) imponham mesmo a intervenção direta, desde que satisfeitos os estritos requisitos para tanto, a começar por lei específica e submissão das relações com o mercado ao regime de direito privado. ${ }^{188}$

Por fim, tem-se o conceito amplo cunhado por Vital MOREIRA que incorpora em si as diversas dimensões associadas à regulação vistas acima. Buscando formular um conceito

\footnotetext{
${ }^{187}$ SALOMÃO FILHO, Calixto. Regulação e Desenvolvimento. (coord.) Regulação e Desenvolvimento. São Paulo: Malheiros, 2002. p. 60.

${ }^{188}$ Essa orientação não é perfilada pela maior parte da doutrina, sendo veemente a oposição que lhe lança Alexandre de Santos ARAGÃO: "Do conceito de regulação está excluída a atividade direta do Estado como produtor de bens e serviços". (Op. cit., p. 23.)
} 
operacional diz o referido autor regulação ser: “(...) o estabelecimento e a implementação de regras para actividade económica destinadas a garantir o seu funcionamento equilibrado, de acordo com determinados objectivos públicos."189 O conceito, bastante sintético, contém núcleos desenvolvidos na exposição do autor que hão de ser vistos mais detidamente, pois, inerentes à conceituação de regulação.

Primeiramente, o autor referencia que regulação se implementa tanto por meios de medidas normativas (sejam expedidas pelo Legislativo, ${ }^{190}$ sejam expedidas pelo Executivo) e medidas de aplicação estrita de tais normas. Ambas as atividades encontram-se debaixo do rótulo regulação. Expressamente:

\begin{abstract}
sob o ponto de vista da forma da coordenação ou modo de 'governação' da economia', não existe diferença relevante quanto aos instrumentos de acção estadual sobre a economia, sejam eles legislativos, sejam eles administrativos. É certo é que, em princípio, toda acção estadual sobre a economia privada há-de pressupor uma norma prévia (lei, regulamento), mas as medidas de execução concreta dessa norma é que dão espessura ao correspondente regime de regulação. Deste modo, o conceito de regulação deve abranger todas as medidas de condicionamento da actividade económica, revistam ou não de forma normativa. ${ }^{191}$
\end{abstract}

O que é de encarecer da citada passagem é que a regulação não se exaure em pôr as regras pressupondo, necessariamente, a sua implementação (dando-lhes "espessura"). É então dimensão indefectível da regulação, não só a edição das regras a conformarem a atuação de determinadas atividades econômicas ao interesse público, mas também a sua efetiva concretização por parte dos entes encarregados desta missão. Logo, nem só de edição de regras vive a regulação, mas, especialmente, de sua atuação eficiente, vale dizer de sua eficaz concretização (para "dar espessura” a ela).

Outra especificidade posta por Vital MOREIRA diz mesmo com a essência da regulação, ou seja, qual a sua nota fundamental. Explicitando esse ponto, aponta: "O essencial do conceito de regulação é o de alterar o comportamento dos agentes econômicos (produtores, distribuidores, consumidores), em relação ao que eles teriam se não houvesse a regulação, isto é, se houvesse apenas as regras do mercado."192 Duas derivações importantes podem ser

\footnotetext{
${ }^{189}$ MOREIRA, Vital. Op. cit., p. 34.

${ }^{190}$ Embora regulação tenha início em medidas legislativas - em especial leis que atribuem competência para atuação de entese da Administração em determinados setores da economia, sói dizer que neste trabalho, que cuida da regulação enquanto uma função de direito administrativo, medidas de cunho legal não são consideradas para fins de integrar o conceito em análise.

${ }^{191}$ MOREIRA, Vital. Op. cit. p. 36.

${ }^{192}$ Idem.
} 
retiradas da passagem. A primeira é que há um compromisso de efetividade da regulação com os objetivos a serem alcançados. Regulação deve alterar o comportamento dos atores regulados. A segunda é de ser a regulação exógena ao mercado, no sentido de impor (por coerção/por indução) a adoção de um determinado modelo que não seria o espontâneo, ditado pela livre combinação das forças econômicas. Ou seja, em se suprimindo a regulação, a conduta do mercado seria diversa da havida em sua presença.

Outra preocupação do autor português é analisar quais as dimensões estão implícitas no conceito de regulação. Nesta análise faz asseverar:

\begin{abstract}
Um processo de regulação implica tipicamente as seguintes fases: formulação das orientações da regulação; definição e operacionalização das regras; implementação e aplicação das regras; sancionamento dos transgressores; decisão dos recursos. Condensando e agregando esses diversos níveis, podem ser reunidos em três etapas essenciais: (a) a aprovação das normas pertinentes (leis, regulamentos, códigos de conduta, etc.); (b) implementação concreta das referidas regras (autorizações, licenças, injunções, etc.). (c) fiscalização do cumprimento e punição das infrações. É por a regulação poder conjugar esses três tipos de poderes - um poder normativo, um poder executivo e um poder parajudicial - que a doutrina norte-americana refere as 'comissões reguladoras independentes' como um concentrado dos três poderes típicos do Estado (legislativo, executivo e judicial)."193
\end{abstract}

O ponto a ser destacado dessa transcrição é a atipicidade da função reguladora se considerada a tradicional especialização funcional legada pela separação dos poderes. Claro que com os devidos temperamentos, colhidos à luz de cada sistema concretamente considerado, a função reguladora apresenta nuances de cada uma das missões reservadas ao Estado, de modo a efetivar sua missão de condicionamento dos comportamentos privados.

Continuando em sua detalhada análise acerca do tema, passa o autor de quem se está a expor o pensamento, a tomar atenção à extensão da regulação, em especial em face da intervenção direta do estado nos domínios econômicos. Como antes assinalado, a maior parte dos autores que cuidam do tema, refuta a intervenção direta como regulação, reservando este termo para atuações estatais indiretas. Não é o caso de Vital MOREIRA. Após observar uma relação precisa de interpenetração entre atuação direta e indireta assevera o autor que pode a participação direta no mercado ter objetivos reguladores, não sendo lídimo suprimir essa manifestação da idéia ampla de regulação ("a actividade económica do Estado pode ter objectivos reguladores da actividade económica privada"194).

\footnotetext{
${ }^{193}$ Ibidem, p. 36-37.

${ }^{194}$ Ibidem, p. 37.
} 
Assim, na concepção de Vital MOREIRA, nada obsta que a regulação seja operada por meio de técnicas que contemplem a atuação direta do Estado na economia, tais recursos podem vir a alcançar o objetivo primacial de modificar o comportamento dos agentes privados, não devendo ser descartado. Embora a intervenção direta na economia, em moldes tradicionais, não seja considerada regulação isso não desnatura esta técnica como apta - em certos casos - a pôr em marcha os objetivos da regulação.

Vistas estas diversas contribuições teóricas pode empreender-se esforço no sentido de sumariar seus diversos elementos.

Nessa linha, podem ser postas as seguintes características a serem consideradas para um conceito de regulação, recolhidas das lições acima transcritas: (i) atuação com vistas a ordenar determinada atividade econômica para satisfação de interesses públicos que, naturalmente, não seriam atendidos; (ii) desempenhada por atos normativos, de execução e de composição de conflitos; (iii) assumindo as mais diversas modalidades e configurações, preferindo atos de intervenção indireta e de incentivo sem, todavia, excluir a imposição coercitiva e a intervenção direta; (iv) incidindo sobre agentes públicos e privados (i.e sobre toda atividade econômica) e (v) garantindo, ao máximo, a real alteração dos conteúdos regulados, legitimando-se pelos resultados (eficiência).

Em defesa desse conceito mais amplo que o habitual na doutrina, que como visto vacila em relação ao tema, há considerações do sistema normativo brasileiro a serem ponderadas que se crê, estão a suportá-lo. A primeira delas diz com a extensão do art. 174 da Constituição que fixa o Estado como agente normativo e regulador da atividade econômica.

Ora, ao fixar estas missões como sendo pertinentes ao Estado, que englobam o núcleo essencial da função reguladora, o art. 174 da CF/88 não aparta a economia privada da economia pública. Ou seja, diz respeito tanto ao serviço público quanto à atividade econômica em sentido estrito. Na função de "planejar o desenvolvimento econômico"195 pode se valer, no exercício de capacidade regulatória, o Estado de condicionamentos aos particulares, todavia, isso não retira a possibilidade de se utilizar, também, da economia estatal para estes fins, o que também está contido no núcleo "regular". Aliás, dando a exata dimensão de que o art. 174 da $\mathrm{CF} / 88$ abrange tanto a economia particular quanto a estatal, tem-se a prescrição de que o planejamento da economia será meramente indicativo para o setor privado. $\mathrm{O}$ fato de o

\footnotetext{
${ }^{195}$ É esse o sentido que atribui Eros Roberto GRAU ao referido artigo (in A Ordem..., p. 270-271).
} 
planejamento destinar-se tanto ao setor público quanto ao privado (todavia, sendo meramente indicativo para este) demonstra que a norma alcança ambos os campos destacados. Neste sentido, é de se ver que a atuação direta do Estado no domínio econômico configura uma estratégia regulatória possível à luz do Texto Constitucional de 1988, não sendo então lídimo reduzir o conceito de regulação apenas a atuações indiretas. ${ }^{196}$

Como bem frisam Calixto SALOMÃO FILHO e Vital MOREIRA (conforme visto acima) a participação direta do Estado na ordem econômica pode vir a configurar-se como estratégia adequada para imposição de condutas aos agentes que nela atuam. A Constituição da República não veda esse recurso, aliás, o prevê de modo bastante expresso. O sentido de "relevante interesse coletivo", definido no art. 173 como legitimador da intervenção empresarial do Estado no domínio da livre iniciativa pode muito bem ser identificado como um objetivo de regulação, desde que respeitadas as condições necessárias para tanto (em especial, a vedação à percepção de privilégios não extensíveis aos particulares e a instituição mediante lei específica).

Feito esse breve escorço, resta justificado, para além da simples avaliação do conceito de regulação, a adoção de uma idéia mais ampla em relação ao tema, também (e fundamentalmente), tendo em vista o direito positivo brasileiro. Concluindo, em se considerando o direito constitucional brasileiro, resta inviável associar a idéia de regulação como contemplando apenas formas de atuação indireta. A própria previsão constitucional que fixa o núcleo do que se compreende por regulação prevê a atuação direta do Estado como empresário quando se refere ao planejamento.

Dentro da função reservada ao Estado (coadjuvado com a iniciativa privada) de conformar a ordem econômica (aqui tomada como cosmo de relações concretas, isto é, o mundo do ser), há a possibilidade de adoção de inúmeros recursos (havendo desde o plano constitucional a reclamada flexibilidade associada à regulação). Todos eles com vistas a permitir a melhor implementação possível dos valores vertidos no art. 170 (e por toda a Constituição), que impõem a busca pela justiça social. Um dos meios para tanto, nada obsta

\footnotetext{
${ }^{196}$ Eros GRAU, aponta que só configuram regulação a intervenção por indução e direção (indiretas), excluindo desse conceito a intervenção por absorção e participação (diretas) (Ibidem, p. 133). Nos termos ora expostos, com o máximo acatamento, não parece ser a melhor solução. Com efeito, a idéia de regulação perpassa todos os núcleos do art. 174 da $\mathrm{CF} / 88$.
} 
que assim não o seja, é a atuação do Estado ombreado à iniciativa privada, exercida nas condições fixadas no art. 173 da Constituição.

O fato de o conceito de regulação vir historicamente associado a movimentos de redução da presença direta do Estado nas atividades econômicas (tomadas em sentido amplo) não pode sustentar a conclusão de que a regulação só contempla a intervenção indireta (e preferentemente via sanção premial). O direito constitucional pátrio impõe conclusão noutro sentido. ${ }^{197}$

Vista a questão afeita à abrangência da regulação, impõe-se analisar o conteúdo da regulação, em especial em relação à aparente dicotomia entre as dimensões econômica e social. A questão remete, como ensina Marçal JUSTEN FILHO, ao movimento de regulação americano em que são visualizadas duas "ondas regulatórias" distintas.

A primeira, diz com a regulação apenas visar à correção de falhas estruturais dos mercados, deixando eles correrem livremente, salvo naqueles aspectos em que se verificam anormalidades que comprometem o próprio funcionamento da economia. Neste sentido, a regulação seria vista como propriamente "econômica", pois focada em garantir o funcionamento do jogo econômico.

A essa primeira "onda", contrapõe-se à visão de que mesmo em funcionamento ideal, por vezes, não logra o mercado atingir finalidades socialmente relevantes. Nestes casos, passou a se advogar por uma regulação dita "social". Nessa linha, objetivos sociais foram incluídos na regulação de modo a que os mercados funcionassem atendendo a outros valores que lhes eram alheios à sua lógica (inclusão no mercado de trabalho, proteção ao consumidor, respeito ao meio ambiente etc.). ${ }^{198}$

Embora a questão seja, usualmente, posta nestes termos pela doutrina (regulação econômica $v s$. regulação social) é de se dizer, é um tanto quanto bizantina. Isto, pois, não há limites precisos para separar a economia da sociedade. É o que notou com argúcia Agustín

\footnotetext{
197 A conclusão pode até sustentar-se com mais facilidade no cenário europeu em que a instituição da Comunidade Européia trouxe uma série de limites que tornam praticamente inviável a atuação de empresas estatais, máxime, dotadas de quaisquer privilégios. Naquele cenário desincentiva-se ao máximo a adoção da atuação direta do Estado na economia. Mesmo o serviço público entendido como atividade reservada aos particulares foi posto em xeque por implicar restrição à livre iniciativa consagrada no plano comunitário. Com base nestes pressupostos faz sentido defender que regulação exclua a atuação direta do Estado nos mercados. Todavia, o suposto fático desse entendimento não está presente no Brasil. Para uma resenha acerca da questão na Comunidade Européia consulte-se Pedro GONÇALVES e Licínio Lopes MARTINS, Op. cit., p. 187-197.

198 Para uma recolha dos diversos argumentos correlatos à discussão "regulação econômica" vs. "regulação social” consulte-se Marçal JUSTEN FILHO (in O Direito..., p. 32-41).
} 
GORDILLO: "Es frecuente leer acerca de la regulación económica y no de regulación social, pero ello parece una dicotomía proclive a errores. Toda regulación social tiene efectos económicos; toda regulación económica tiene efectos sociales."

Em que pese a questão parecer sequer se sustentar do ponto de vista teórico, há de se examiná-la à luz do direito positivo pátrio para remarcar a absoluta impossibilidade, em no sistema brasileiro, de se advogar por uma regulação exclusivamente econômica (tomando esse termos como se encerrando em si mesmo). Como visto, bem analisados os conceitos teóricos de regulação, já se pode concluir no sentido de ser a regulação econômica e social (e nunca só econômica). A pesquisa na ordem jurídica brasileira só faz acentuar essa conclusão.

Isto por uma razão mais do que elementar. A pesquisa mais tênue nos dispositivos da Constituição de 1988 que regem a interação do elemento jurídico com o econômico demonstra que a atividade econômica se orienta não apenas em favor de quem a explora, mas também em vistas de elementos sociais.

$\mathrm{O}$ art. 170 e diversos outros da Constituição não dão margem a qualquer margem de engano. Com efeito, toda a exploração econômica, inclusive a estritamente privada, se orienta ao atingimento de missões sociais. Há princípios que determinam objetivos a serem implementados e justificam (i.e. impõem) que o Estado desenvolva suas ações de modo a atingi-los. Note-se que, evidentemente, há a necessidade de um equilíbrio dinâmico entre a atuação particular e esses objetivos. É legítima a atuação privada em busca da apropriação individual dos resultados e são garantidos os meios para tanto. Todavia, a ordenação jurídicoconstitucional do espaço econômico impõe a compatibilização da busca privada por resultados econômicos com objetivos sociais, operando-se a idéia de funcionalização das relações econômicas (como bem atestam a função social da propriedade e do contrato instrumentos jurídicos inerentes à geração privada de riquezas).

Nenhum desses vértices pode se anular sob pena de subversão grave da ordem constitucional brasileira. A exploração privada deve, em certa medida, alcançar objetivos socialmente úteis, sendo tutelada e legitimada por conta disso. ${ }^{200}$

Aliás, a própria regulação ao buscar impor pautas externas à atuação econômica, dando a ela sentidos e objetivos que não são os naturalmente seus, implica na idéia de

\footnotetext{
${ }^{199}$ GORDILLO, Agustín. In Tratado ..., t. 2, p. VII 6.

${ }^{200}$ Em relação ao tema remetemos as considerações já feitas acima acerca do pensamento do Professor Fábio Konder COMPARATO (In Função social...).
} 
funcionalização como, aliás, percebe-se do magistério de Marçal JUSTEN FILHO, que dá destaque a essa nota:

(...) o modelo de Estado Regulatório exige uma intervenção muito mais consistente, de natureza interna. O Estado retirou-se do cenário econômico: as necessidades coletivas devem ser satisfeitas pela atuação apenas dos próprios particulares. (...) Todas as atividades, inclusive aquelas até então desenvolvidas pelo Estado, são assumidas pelos particulares, mas assujeitadas a controle intenso e contínuo, com a finalidade de conduzir os particulares a atingir resultados necessários ao bem comum. ${ }^{201}$

Está a se observar, então, um conceito que pode ser identificado com aquilo que os teóricos nomeiam de "regulação social". Isto é, estão abrangidas no conceito não só as atuações da Administração sobre aspectos econômicos, estritamente considerados (supondo que eles existam de modo autônomo), mas também a disciplina de objetivos outros de ordem nitidamente social (tais como: os interesses dos consumidores, o respeito ao meio ambiente, aos direitos dos usuários de serviços públicos, dentre outros valores dessa ordem).

Assim o impõe, com palmar evidência, o art. 170 da Constituição, que identifica a ordem econômica com um espaço que não se reduz apenas à consagração do lucro pelos particulares, mas fixa uma série de objetivos sociais a serem alcançados. Acentuando esse aspecto anota com a autoridade que lhe é reconhecida, Fábio Konder COMPARATO:

A Constituição, com efeito, declara que a ordem econômica deve assentar-se, conjuntamente, na livre iniciativa e na valorização do trabalho humano. E assinala que o objetivo global e último dessa ordenação consiste em 'assegurar a todos existência digna, conforme os ditames da justiça social' (art. 170, caput). É em função desse objetivo último de realização da justiça social que devem ser compreendidos e harmonizados os demais princípios expressos no art. 170, a par da livre concorrência, a saber, especificamente, a função social da propriedade, a defesa do consumidor, a redução das desigualdades regionais e sociais, a busca do pleno emprego e o tratamento favorecido para as empresas brasileiras de capital nacional e de pequeno porte. ${ }^{202}$

A cogitação de uma regulação meramente econômica (além de refletir previamente vinculação com uma idéia liberal de que o mercado é um espaço próprio, separado da sociedade $^{203}$ ) não se sustenta à luz do referencial mais elementar do direito positivo brasileiro.

\footnotetext{
${ }^{201}$ JUSTEN. FILHO Marçal. O Direito..., p. 28.

${ }^{202}$ COMPARATO, Fábio Konder. Regime constitucional do controle de preços no mercado, in Direito Público Estudos e Pareceres, São Paulo: Saraiva, 1996, p. 102-103.

${ }^{203}$ Refutando o pensamento daqueles que lêem "regulação" como sinônimo de afastamento definitivo do Estado da economia, lembra Egon Bockmann MOREIRA: "Ocorre que a Constituição brasileira é detentora de algumas peculiaridades marcantes no campo da Ordem Econômica: ela não celebra apenas a livre empresa, que não configura um princípio autônomo no seio do texto constitucional, nem mesmo no contexto da ordem
} 
Dito de modo claro, o exercício da função de regulação só se legitima em sendo operado para dar conta dos compromissos do Estado Brasileiro de transformação da ordem econômica, implementando os valores constitucionalmente assinalados.

Tais elementos são inerentes a uma proposta de sistematização que vise a dotar a regulação de algum conceito que seja operacional: nem tão estreito que não corresponda aos marcos impostos pelo direito positivo pátrio, nem tão amplo que impeça qualquer tentativa de sistematização.

\subsection{REGULAÇÃO ENQUANTO SÍNTESE DE NOÇÕES RESTRITIVAS E PRESTACIONAIS}

Uma vez sumariados os elementos que estão imbricados no conceito de regulação, explicitados seu âmbito de abrangência e conteúdo, cumpre levar a efeito outro núcleo de análise. Importa posicionar a função regulatória em relação às noções de poder de polícia e serviço público que a antecederam no sentido de justificar a relação entre a atuação concreta do Estado e o espaço econômico.

Como já se assinalou acima, o modelo de Estado Liberal tinha como categoria unificadora da atuação estatal a idéia de poder de polícia. Ao seu turno, o Estado Social, haja vista ser caracterizado pelo seu aspecto prestacional, caracterizou-se, essencialmente, ao redor da noção de serviço público, que servia de categoria estruturante de sua atuação. Também, deixou-se indicado que a regulação seria a categoria típica do Estado Pós-Social e que ela incorporaria aspectos de ambas as noções que a precederam sem, todavia, confundir-se por completo com qualquer uma delas.

A idéia deve ser retomada e aclarada, uma vez já identificados os elementos essenciais do conceito de regulação.

Cabe, nesta linha, pôr em cotejo os conceitos envolvidos para ver seus momentos de aproximação e distanciamento, articulando-os.

econômica (o que fragmentaria sua unidade e harmonia). A sua leitura é inseparável dos princípios conformadores do Texto Maior". (O Direito Administrativo da Economia, a Ponderação de Interesses e o Paradigma da Intervenção Sensata, in Estudos de Direito Econômico, Belo Horizonte: Fórum, 2004, p. 62.) 
Em relação ao poder de polícia, nítida é a vinculação da regulação com esta categoria, havendo autores, inclusive, que identificam expressamente ambos os conceitos. ${ }^{204}$ Para alguns, a regulação não passaria da expressão moderna do poder de polícia, adaptada aos desafios da contemporaneidade. $\mathrm{O}$ fato de a regulação, não raro vir a restringir determinados bens jurídicos impõe-lhe uma semelhança óbvia com o poder de polícia, categoria que desde o tempo do Estado Liberal explica os condicionamentos estatais à liberdade e à propriedade.

Contudo, mesmo reconhecendo que parte da doutrina assim o faz, não parece que os conceitos seja perfeitamente intercambiáveis. Há notas em relação à idéia de regulação que não são redutíveis às possibilidades teóricas que se reconhecem ao poder de polícia, consoante tradicionalmente encarado.

Antes de qualquer análise, todavia, há de se retomar a própria evolução do poder de polícia. Como visto, em um primeiro momento, a idéia abrangia apenas as restrições sobre o patrimônio e sobre a liberdade, consubstanciando a imposição de obrigações de não fazer em prol do bem estar público. É neste sentido a construção liberal do poder de polícia, que se coaduna com uma Administração tida por agressiva, ou seja, que apenas limitava o patrimônio jurídico dos particulares (que deveria ser salvaguardado ao máximo da atuação estatal). Essa nota de restrição do patrimônio jurídico dos particulares fica intimamente atrelada à noção de poder de polícia.

Com a emergência do Estado Social, como já assinalado, as tarefas postas sob os auspícios do Poder Público aumentaram em muito, bem como outras missões estatais foram criadas. Em especial, setores antes absolutamente infensos à atuação do Estado passaram a ser objeto de sua atenção, o que exigia uma justificação jurídica para esse fenômeno. Nesta linha, o próprio poder de polícia evoluiu para alcançar áreas antes não cogitadas, o que opera uma mudança sobre a sua estruturação original. Passa a se falar em polícias especiais, para designar estes campos que superam a noção tipicamente liberal do instituto. $\mathrm{O}$ exemplo claro disso são normas emanadas sobre a atividade comercial, conformando a liberdade dos atores privados no mercado. ${ }^{205}$

\footnotetext{
204 Neste sentido afirma Marçal JUSTEN FILHO: "Sob certo ângulo, a regulação consiste na utilização permanente, racional e intensificada das competências de poder de polícia." (In Curso..., p. 452.)

${ }^{205}$ Em seu texto célebre acerca do poder de polícia, anota Caio TÁCITO: "O conceito moderno ultrapassa, porém, as fronteiras conservadoras para reconhecer ao Estado um papel mais amplo e ativo na promoção o bem-estar geral, estabelecendo não somente no tocante à ordem pública, mas sobretudo no sentido da ordem
} 
Passa-se, inclusive, a se reconhecer que o poder de polícia podia impor obrigações de fazer aos administrados, não só lhes obrigando abstenções, mas também ações. O Estado Social opera uma transformação ao nível da noção de poder de polícia, alargando-a horizontal e verticalmente. ${ }^{206}$ Continua presente o núcleo elementar da noção, restrição do patrimônio jurídico em prol da coletividade.

No primeiro sentido, a noção de poder de polícia fica bastante distante da de regulação. Obviamente, a regulação é bastante mais complexa do que deveres negativos impostos aos particulares em vista do bem comum. Essa concepção não dá conta de explicar a atuação do Estado sobre o mercado por meio de técnicas que visam a constranger o particular a tomar alguma atitude socialmente relevante.

No segundo sentido - isto é o poder de polícia já incorporando noções do Estado Social - a distinção torna-se mais difícil, pois, se admite que nele está contida a possibilidade de constranger o particular a fazer algo. Todavia, crê-se que nem com as transformações já vistas, confundem-se regulação e poder de polícia, ainda que tomado nessa acepção mais ampla. Mesmo em sua concepção no Estado Social, poder de polícia não se confunde com regulação. Isto por algumas razões que posem ser sumariadas.

Primeiramente, como já visto, a regulação pode valer-se de técnicas que consubstanciam a participação direta do Estado no mercado que não conseguem ser reconduzidas à noção de poder de polícia. A própria presença da Administração em um mercado pode ser encarada como uma técnica regulatória e isto desborda da noção de poder de polícia. Neste caso, os objetivos sociais de transformação do funcionamento do mercado são alcançados por intermédio não de qualquer restrição à participação dos agentes e sim pela amplificação da margem de atuação do Estado.

Outra dimensão que afasta os dois conceitos é a possibilidade de recurso a sanções premiais, que acrescem o patrimônio de alguém, caso ele adote uma postura socialmente desejável. A idéia de polícia conta apenas, mesmo na sua formulação mais ampla, com o instrumental de restrição de um direito do particular, lhe sendo imposta uma obrigação (de fazer ou não fazer, pouco importa). No núcleo do poder de polícia está uma restrição em prol

econômica e social, normas limitadoras da liberdade individual, que se exercem, em grande medida, por meio do poder de polícia." (In O Poder..., p. 524.)

${ }^{206}$ Neste sentido amplo na doutrina brasileira, embora haja cultores de um conceito mais restrito, consulte-se Maria Sylvia Zanella DI PIETRO. (In Direito..., p. 109-110.) 
da coletividade (ainda que ela se traduza em uma obrigação de fazer). Ora, nos casos em que se adotam sanções premiais, essa nota de restrição não se faz presente. O que há é, justamente, a ampliação do patrimônio jurídico de alguém tendo em vista uma conduta socialmente útil (o que estaria abrangido, quando muito, na noção de fomento). Novamente, a noção de polícia, embora integre uma dimensão essencial da regulação, não se confunde com ela.

Por fim, crê-se, que a regulação supera o poder de polícia ao adotar um compromisso efetivo com a produção, tangível, dos resultados visados. Ainda que se adote um conceito de poder de polícia que vá além da velha idéia liberal que a ela deu origem, parece haver um plus em relação à regulação, consoante exposto acima. É essa nota de preocupação finalística e legitimação pelos resultados (sem abandonar as formas) que caracteriza a idéia de regulação. Há sem dúvida, sobre este viés, um salto qualitativo que não pode ser desprezado.

Ainda que se falasse em polícia neste caso, a imposição de uma legitimação por resultados traria uma nova racionalidade ao instituto que o apartaria da antiga noção. Basta que se pense na inadequação do controle de legalidade a que se submete o poder de polícia em sua acepção tradicional quando se cogita de regulação para que se perceba a distância entre eles. ${ }^{207}$ Qualquer tentativa de aludir a um novo poder de polícia para descrever a regulação escamoteia o fato de estar se tratando de noções sujeitas a lógicas distintas.

Neste sentido, por exemplo, aponta parte da doutrina portuguesa: "verifica-se que ao quadro dos princípios de base liberal da 'polícia económica' (sobretudo preventivos e repressivos), o direito económico contemporâneo vem acrescentando preocupações finalistas (por exemplo, o desenvolvimento económico, a competitividade externa) que pressupõem actuações positivas e não meramente negativas das autoridades públicas". ${ }^{208}$ A idéia de polícia não remete necessariamente a esta concepção de necessária produção de resultados, que a aproximaria de uma lógica prestacional que lhe é ontologicamente estranha. Não basta à regulação que haja mera previsão abstrata de resultados, há a necessidade de que, efetivamente, se opere a transformação das condutas o que a qualifica em relação à noção de poder de polícia que não encerra em seu bojo de modo expresso essa idéia de atuação sistêmica e perene.

\footnotetext{
${ }^{207}$ A questão do controle será tratada no próximo capítulo com maior vagar.

208 SANTOS, António Carlos dos; GONÇALVES, Maria Eduarda; MARQUES, Maria Manuel. Direito Económico, 4. ed. Coimbra: Almedina, 2001, p. 195.
} 
Com efeito, por qualquer ângulo que se tome a questão, regulação não é recondutível ao conceito de polícia administrativa. Visto isto, cumpre agora aproximar a regulação de seus aspectos prestacionais, até para tornar mais clara a última idéia exposta.

Regulação, como já dito, traz em si uma nota prestacional. Com efeito, a atuação desenvolvida pela via da função regulatória deve garantir certos elementos à coletividade, dentro de condições reputadas adequadas em vistas da especificidade de determinado campo da atividade econômica. Neste sentido, é de se ver que a atividade de regulação não se apresenta como meramente abstrata e deve, de modo tangível, garantir objetivos de ordem pública, aptos a estabelecer uma relação de adequação entre o quê está sendo oferecido pelo mercado e os interesses dos destinatários dessa atuação. A ponderação e a articulação de todos os interesses é essencial neste procedimento, cabendo à atividade regulatória garantir o atendimento dos fins públicos, fazendo com que determinada atividade econômica venha atingir os objetivos fixados. Com efeito, é da essência da regulação que ela gere benefícios que são apropriados pela sociedade.

Tal dimensão se visualiza com maior facilidade, em relação aos serviços públicos trespassados à iniciativa privada (seja por concessão, seja por permissão). Nestes casos, a regulação, na sua multicidade de formas de atuação, deve garantir aquilo que pode se reconduzir ao conceito de serviço público adequado; em especial, devem ser garantidos os princípios inerentes a essa categoria. ${ }^{209}$

Com a retirada do Estado da prestação direta de um serviço público, deve ser elaborado um arcabouço jurídico apto (abstrata, funcional e concretamente) a garantir as notas que peculiarizam tais atividades, implementando as garantias subjacentes à sua reserva para iniciativa estatal. Segundo Fernando Herren AGUILAR a própria decisão de franquear a gestão de um serviço público a um particular constitui uma estratégia regulatória que, todavia, implica na elaboração de normas que assegurem os objetivos públicos implicados em tal atividade. Nesse sentido, anota o autor:

\footnotetext{
${ }^{209}$ A doutrina, remetendo à doutrina de Rolland, aponta usualmente os seguintes princípios como integrando o conceito de serviço público: continuidade, mutabilidade do regime de prestação em vistas do fim público e igualdade no acesso. Há doutrinadores que adotam classificações mais amplas, derivando desse núcleo outros princípios nele implícitos. Para uma classificação sintética consulte-se Maria Sylvia Zanella DI PIETRO (in Direito..., p. 101-103) e para uma mais analítica Celso Antonio Bandeira de MELLO (Curso..., p. 637-641).
} 
A concessão de serviços públicos a empresas particulares, porém não significa uma renúncia do Estado em relação a esses serviços. Ao contrário, é ele o responsável constitucional pela sua adequação e efetividade social. Apenas delega o Estado ao particular uma etapa de sua implementação, que é a concreta prestação dos serviços. Essa delegação pode ser justificada em conveniências administrativas, financeiras, busca de maior eficiência operacional, redução de custos ou escassez de recursos estatais para o empreendimento. De qualquer forma a concessão é sempre um mecanismo de direcionar recursos privados para atividades públicas. A concessão de serviços públicos (ou a sua permissão) é um mecanismo regulatório que instrumenta uma desconcentração regulatória operacional. (...) a contrapartida necessária da desconcentração regulatória operacional em matéria de serviços públicos é a concentração regulatória normativa, o controle estatal, por exigência constitucional. Ou seja, para que seja possível a outorga de prestação de serviços públicos aos particulares, se faz necessária a existência de mecanismos de regulação normativa. ${ }^{210}$

Nesse primeiro sentido, é evidente a relação da regulação com a idéia de serviço público. No campo de serviços públicos, cuja execução é franqueada à iniciativa privada, regulação é (melhor, deve ser) garantia do atendimento dos fundamentos mesmos que legitimam a instituição de uma atividade como sendo da iniciativa do Estado. Regulação, nesse âmbito, vincula-se com a oferta de prestações à coletividade de modo adequado.

Ao optar pela prestação indireta, o Estado não deixa de ter responsabilidade sobre a oferta efetiva das materialidades tidas como serviço público, exatamente como diz o art. 175 da CF/88: “Incumbe ao Poder Público (...) a prestação de serviços públicos.” Regulação, no campo dos serviços públicos concedidos ou permitidos, é sinônimo de prestação adequada destas atividades, como bem destaca Fernando Herren AGUILAR. Mesmo a adoção de regimes que não consagram a exclusividade na prestação da atividade, investindo na concorrência como modo de gerar uma prestação adequada aos usuários, consagram obrigações aos agentes econômicos que visam a assegurar que certos valores serão assegurados, o que não estaria pela simples adoção do regime de mercado.

Todavia, é de se ver que esta nota que associa regulação a um aspecto prestacional (prestação adequada) não se esgota em relação aos serviços públicos expressamente definidos com tal no sistema brasileiro.

A relação entre tais idéias alcança também setores que vão além do serviço público e estão sujeitos à livre iniciativa (vale dizer, são atividades econômicas em sentido estrito). Tal

\footnotetext{
${ }^{210}$ Fernando Herren AGUILAR. Controle Social dos Serviços Públicos. São Paulo, Max Limonad, 1999, p. 213. É interessante notar que o autor classifica a regulação em um esquema binário. De um lado, a regulação dita operacional que toca ao nível de participação do Estado nas atividades econômicas (em sentido amplo). De outro a dita regulação normativa que diz com a expedição de comandos sobre as atividades. Em torno dessas duas categorias o autor visualiza distintas estratégias macro de regulação, articulando esses dois núcleos (Ibidem, p. 212). O argumento valida, ainda que de modo um tanto quanto diverso, a opção feita no presente estudo de abordar a intervenção do Estado nas atividades econômicas em sentido estrito como forma de regulação.
} 
nota prestacional da regulação estende-se a atividades privadas (i.e. que não são qualificadas como serviços públicos) que, entretanto, contam com notas de relevância social. Tais atividades passam, pois, a ser objeto da atuação estatal de modo a promover valores que superam a mera exploração mercadológica. ${ }^{211}$

Aliás, tal a importância dos elementos que visam adequar essas prestações para padrões de satisfação coletiva (à moda do serviço público) que, não raramente, tais atividades são chamadas na Europa de serviços públicos virtuais. Tal nomenclatura destaca a aproximação dos dois elementos tendo em vista a sorte de obrigação que é imposta àqueles que as exploram. O claro desestímulo à reserva de atividades para os Estados Nacionais na Comunidade Européia levou à criação de figuras jurídicas em que se admite a imposição de obrigações aos prestadores que visam à satisfação dos seus beneficiários (tais como: serviço de interesse econômico geral, serviço universal e atividades com obrigações de serviço público). Nestes casos, a preocupação é garantir a qualidade dos serviços sem recorrer à sua atribuição subjetiva ao Estado, garantindo que os privados dêem conta de prestar tais atividades em níveis de qualidade satisfatórios à população que não seriam garantidos pela concorrência apenas. $^{212}$

Embora no Brasil a discussão não se ponha nas mesmas claves que o tema suscita na Europa, é de se dizer que dentre nós diversas atividades privadas estão a se submeter em sua prestação a uma lógica que se pauta, exatamente, na garantia dos interesses dos seus destinatários para além dos expedientes de defesa do consumidor. Ou seja, a imposição de pautas sociais ao desempenho de atividades privadas não é desconhecida no sistema brasileiro, que não circunscreve regulação aos serviços públicos trespassados à gestão privada.

\footnotetext{
211 O tema foi objeto de estudo específico de Alexandre dos Santos ARAGÃO Atividades Privadas Regulamentadas. . (coord.) O Poder Normativo das Agências Reguladoras. Rio de Janeiro: Forense, 2006, p. 221-269.

${ }^{212}$ Para uma aproximação com as "novas fórmulas que traduzem a ruptura com a idéia de serviço público subjetivo" consultar Pedro GONÇALVES e Licínio Lopes MARTINS. Op. cit., p. 197-226.
} 
Neste sentido, por exemplo, setores como saúde suplementar ${ }^{213}$ e venda a varejo de combustíveis, ${ }^{214}$ embora reservados à iniciativa privada, ${ }^{215}$ são regulados. Nestes casos há a incidência de regulação no sentido de possibilitar a satisfação de objetivos sociais, o que os aproximam de atividades prestacionais. Aliás, em alguns casos o regime de prestação das atividades, mesmo sendo privado, aproxima-se de notas essencialmente reconhecidas ao serviço público. Nestes casos impõem-se comandos aos agentes econômicos que buscam assegurar aos seus destinatários que tais utilidades serão prestadas de modo satisfatório dentro de padrões estabelecidos em favor da sociedade (seja em termos de qualidade, acessibilidade, quantidade, continuidade etc.).

\footnotetext{
${ }^{213}$ A assistência à saúde é livre para ser explorada em regime de mercado pela iniciativa privada como afirma peremptoriamente o art. 199 da Constituição Federal. Todavia, é classificado como serviço de relevância pública, estando sujeito, nos termos do art. 197 da CF/88, a "regulamentação, fiscalização e controle", isto é, constitucionalmente deve ser regulado. A lei n. ${ }^{\circ}$ 9961/00 cria a Agência Nacional de Saúde Suplementar - ANS, no famigerado regime autárquico especial, como "órgão de regulação, normatização, controle e fiscalização" de tais atividades (cf. art. $1^{\circ}$, da referida lei). A sua finalidade institucional diz com "promover a defesa do interesse público na assistência suplementar à saúde" (cf. art. $3^{\circ}$ da lei). Analisando o vasto rol de competências atribuído a esta agência, destaque-se a seguinte: "exercer o controle e a avaliação dos aspectos concernentes à garantia de acesso, manutenção e qualidade dos serviços prestados, direta ou indiretamente, pelas operadoras de planos privados de assistência à saúde." (cf. art $4^{\mathrm{o}}$, XXIV). Ao garantir condições de acesso e qualidade aos consumidores de tais serviços, que são atividades exploradas no regime de iniciativa privada, o regime de sua prestação é dotado de garantias particulares. Aliás, note-se que garantia de acesso e qualidade são elementos também a serem garantidos em relação aos serviços públicos, o que aproxima os dois regimes, desde o ponto de vista do seu conteúdo. Nesse caso, está-se garantindo o acesso, ainda que não com toda a extensão do regime de direito público, a uma utilidade, a ser fruída pelos cidadãos, por meio de regulação. Do que importa destacar há um nítido caráter prestacional na regulação efetivada em relação a este setor. Aliás, mesmo os tipos de litígio advindos do inadimplemento - no que toca à continuidade em razão da dimensão social da prestação - são assemelhados aos que envolvem serviços públicos. Neste campo não raro as discussões judiciais visam a (i) questionar a extensão dos serviços oferecidos buscando se impor a cobertura a tratamentos tidos por relevantes e (ii) exigir a continuidade de tratamentos, mesmo em casos de inadimplência. Essa mesma estrutura de litígios pode ser vista no que toca aos serviços públicos, concedidos ou não.

${ }^{214}$ A regulação da venda a varejo de combustíveis tem por objetivo assegurar, além de padrões de qualidade e um adequado grau de informação para o consumidor ainda antes de adentrar o estabelecimento revendedor, a continuidade do abastecimento. É a garantia da continuidade do fornecimento de combustíveis a pedra de toque da regulação do setor(cf. art. $1^{\circ}$, V da Lei no 9.478/97). Essa obrigação de continuidade sem muita dificuldade pode ser reconduzida à lógica vigente em relação aos serviços públicos.

${ }^{215}$ Nesta análise, pelas razões a seguir expostas, estão excluídos os chamados serviços públicos "não exclusivos do Estado" ou "impróprios" (v.g. saúde e educação) do âmbito estrito dos serviços públicos. A análise deles não se faz pertinente ao caso, pois, tais atividades, caso sejam desenvolvidos por particulares, o são como exploração de atividade econômica em sentido estrito; ou seja, o núcleo "serviço público" só existe na prestação direta pelo Estado de tais atividades. Desse modo, subsiste um núcleo de "livre iniciativa" em relação a tais atividades. Assim, fica excluída a possibilidade de uma gestão privada desses serviços públicos, o que só ocorre, em sentido próprio, nos chamados serviços públicos exclusivos ou próprios. Nos serviços "não exclusivos" a prestação privada, dissolve o núcleo "serviço público", o que retira essas cogitações da ordem de indagações ora propostas. Ressalva-se, contudo, o entendimento de Eros GRAU que, partindo da análise do elemento material, determinante para si, trata tais atividades, não importa quem as esteja a prestar, como serviços públicos (in $A$ Ordem..., p. 108).
} 
Essas considerações demonstram que a associação de regulação com oferta adequada de utilidades à sociedade não está restrita ao campo que, formalmente, é considerado serviço público, indo além dele.

$\mathrm{O}$ fato de a regulação impor padrões à prestação de atividades privadas (garantindo acesso universal, continuidade, adequação etc.) para a sociedade demonstra que ela tem um caráter prestacional evidente. Sob um certo ângulo, a regulação é um sucedâneo da noção de serviço público.

Ou seja, por meio da regulação garante-se que em mercados tidos por de interesse coletivo o seu funcionamento implicará na oferta, em condições adequadas, de materialidades aos particulares. Isso sem recorrer ao regime de serviço público, em que se associa a adequação da prestação à reserva de titularidade estatal. Por meio da regulação descola-se a idéia de prestações adequadas da necessária titularidade estatal das atividades e da necessária adoção de um regime distinto dos particulares.

Desde um ponto de vista teleológico, o ideário da regulação implica na efetividade da atuação estatal em prol do atendimento de necessidades sociais. Não basta, no plano abstrato apenas, instituir controles que visam a aproximar a conduta dos regulados de pautas socialmente úteis. É necessário mais do que isso; é forçoso buscar por todos os meios o atingimento dessas metas, sendo esse um fator preponderante da dinâmica da regulação. É por essa razão de fundo, que se aproximam as atividades particulares das prestadas em regime estrito de serviço público, autorizando alguns autores a proclamar a ociosidade da distinção.

Em ambos os casos (admitidos matizes variáveis em função da relevância de cada atividade), surge a necessidade de se funcionalizar uma atividade em prol de interesses que transcendem a sua mera organização privada. Seja a iniciativa privada seja pública a explorar de modo organizado determinada atividade, ela resta funcionalizada em razão de objetivos sociais implementados pela regulação.

Em última instância, mesmo nos casos em que a regulação não esteja atrelada a atividades que dizem respeito com a oferta concreta de utilidades à coletividade (indiferente o regime jurídico adotado para tanto) ainda há um ônus de a regulação visar à melhoria das condições gerais, satisfazendo aos interesses da sociedade. Mesmo que não haja um caráter prestacional direto (que muitas vezes está presente a depender da relevância de determinada atividade), há ainda a necessidade de a atuação regulatória gerar uma melhor condição social 
do que a operada exclusivamente pelo mercado. Anota Egon Bockmann MOREIRA em passagem que realça esse aspecto: "cumpre ao Estado estabelecer limites à atuação dos agentes econômicos privados, bem como gerar meios de uma melhor distribuição de riqueza. Isso através da regulação normativa ou da intervenção direta - regulando ou agindo, cabe ao Estado gerar os benefícios sociais que o mercado não produz. Essa é a leitura que se propõe à Ordem Econômica da Constituição de 1988". ${ }^{216}$

Na mais tênue das hipóteses a atividade regulatória deve gerar (i.e. tem por objetivo) benefícios sociais, o que lhe empresta um caráter, ainda que indiretamente neste último caso, prestacional.

Tal atuação não está apta a ser explicada pela idéia de poder de polícia. Sente-se com facilidade a inadequação dos instrumentos que traduzem a atuação do poder de polícia para explicar a atuação nessas atividades privadas de interesse sociais sujeitas à regulação. É o que se vê, por exemplo, com a figura da autorização que tem passado, ultimamente, por modelagens que a afastam de sua concepção clássica.

Usualmente, a autorização é tida como fruto do exercício de competências de polícia, caracterizando-se pela discricionariedade na sua concessão unilateral e pela sua precariedade. ${ }^{217}$ Contudo, o entendimento tradicional acerca do tema tem causado grande celeuma quando aplicada em relação às atividades privadas reguladas, em especial, aquelas que exigem grandes aportes de capital e induzem a relações de trato sucessivo entre o Estado e o particular. ${ }^{218} \mathrm{Um}$ dos meios comumente utilizados para regular setores privados é submeter os agentes econômicos à necessidade de obter uma autorização que, além de lhes permitir o acesso à atividade, lhes impõe uma atuação conforme diversos padrões de qualidade. ${ }^{219} \mathrm{O}$ desrespeito a essas pautas pode levar, no limite, à cassação da autorização e em casos menos graves à imposição de penalidades. Ou seja, transferiu-se a utilização das autorizações para o campo das atividades econômicas de interesse coletivo que não podem conviver com os

\footnotetext{
${ }^{216}$ MOREIRA, Egon Bockmann. O Direito..., p. 69.

217 Sobre o conceito de autorização anota Maria Sylvia Zanella DI PIETRO: "ato administrativo, unilateral, discricionário e precário pelo qual a Administração faculta ao particular o uso privativo de bem público ou a prática de ato que, sem esse consentimento, seriam legalmente proibidos." (In Direito..., p. 219.)

${ }^{218}$ Para uma resenha da questão das autorizações como títulos para exploração de atividades econômicas, consulte-se Alexandre Santos de ARAGÃO. (In Atividades..., p. 243-269.)

${ }^{219}$ Tamanha a importância das autorizações nesse campo que Santiago Muñoz MACHADO se refere à regulação das atividades privadas de interesse público como uma "regulação por autorizações". (Op. cit., p. 1215-1218)
} 
atributos da unilateralidade, da discricionariedade e da precariedade que usualmente são apontados como suas características. ${ }^{220}$

Não é só. As autorizações nestes campos não têm por escopo apenas admitir que o particular venha a desenvolver algo que sem ela, não poderia fazer por conta de restrições decorrentes do poder de polícia. As autorizações são instrumentos jurídicos neste caso destinados a possibilitar a efetiva adequação da atividade autorizada às pautas julgadas conformes pela Administração. Não se cuida de um ato episódico que uma vez praticado relegará o particular à sua própria sorte e, sim, cuida-se de ato de conteúdo regulamentar que visa a disciplinar a atuação do agente privado dentro de um mercado em que se julga necessário atingir fins que não são garantidos pelo seu funcionamento ordinário.

Assinalando a distinção ora posta, é de trazer-se à colação o entendimento de Eduardo Garcia de ENTERRÍA e Tomás-Ramón FERNÁNDEZ:

La crisis del esquema tradicional se ha hecho especialmente aguda a partir del momento en el que, rebasando el ámbito propio del orden público, en su triple dimensión comprensiva de la tranquilidad, seguridad y salubridad ciudadanas, en función del cual fue pensado dicho esquema, la autorización se ha visto transplantada al complejo campo de las actividades económicas, en el que se le hace sistemáticamente un papel que no se reduce ya al simple control negativo del ejercicio de derechos, sino que se extiende a la regulación misma del mercado, con el propósito decidido de orientar y encausar positivamente la actividad autorizada en el sentido de unos objetivos previamente programados o al menos, implícitamente definidos en las normas aplicables. 221

Do que importa destacar é que a necessidade de repensar o conceito de autorização nesse campo demonstra a inadequação do conceito de poder de polícia para explicar o exercício de regulação nesses setores. A distinção entre a autorização para a prestação de atividade econômica e a autorização, por assim dizer, tradicional, só faz escamotear a inadequação de tentar se explicar a regulação com base exclusivamente no poder de polícia de inspiração liberal. A diferença em relação aos instrumentos é repercussão da distinção entre as suas categorias estruturantes, demonstrando a tensão entre poder de polícia e regulação.

A análise levada a efeito, demonstra que a regulação tem um nítido aspecto de garantir o acesso a determinadas utilidades de modo adequado (socialmente útil), funcionalizado a posição dos agentes que estão a explorar tais atividades. Se não tanto, pelo menos, deve ter por

\footnotetext{
${ }^{220}$ Esta é, por exemplo, a natureza da polêmica autorização vinculada no serviço de telefonia prevista no art. 131, $\S 1^{\circ}$ da Lei $n^{\circ} 9.472 / 97$.

${ }^{221}$ ENTERRÍA, Eduardo Garcia de; FERNÁNDEZ, Tomás-Ramón. Op. cit., p. 136.
} 
escopo gerar benefícios sociais à coletividade, o que a aproxima, filosoficamente, da idéia de serviço público.

A concepção de que as atividades do Estado devem garantir benefícios à população informa a regulação assim como esteve na base da afirmação teórica do serviço público (especialmente se considerarmos suas acepções mais amplas).

Com efeito, anota Celso Antonio Bandeira de MELLO acerca do pensamento de León DUGUIT, que a afirmação do conceito de serviço público tinha por ensejo, justamente, legitimar o exercício do poder estatal ao redor de uma noção que englobasse as utilidades geradas à sociedade, e não se exaurisse em si. ${ }^{222}$ Nesta concepção, o poder seria justificado pelos benefícios passíveis de serem ofertados aos particulares (estando aí o serviço público sendo que nessa noção seminal o tema era visto de modo absolutamente amplo). Embora esse conceito amplo tenha dotado o conceito de pouca operacionalidade prática, é de se ver que na medida em que ele implica na legitimação das funções estatais pelos efetivos benefícios ofertados à coletividade, aproxima-se da idéia de regulação. Aproximação que se dá inequivocamente por conta da nota prestacional.

Regulação também se legitima pela oferta de melhores condições à sociedade, guardando nesse sentido uma certa correspondência com as idéias prestacionais que viabilizaram o surgimento do serviço público enquanto categoria jurídica que buscava caracterizar a essência da administração. Embora as bases teóricas sejam distintas, há uma unidade em relação aos escopos a serem buscados. A finalidade, em ambas as técnicas, é gerar benefícios sociais efetivos que não decorrem do funcionamento ordinário da sociedade.

Nesta linha, é que se aproxima a regulação do serviço público, unidas ambas as idéias por um indelével aspecto prestacional, legado imprescritível do Estado Social.

É em atenção a estes pontos de proximidade da função de regulação com as noções de poder de polícia e serviço público que se diz que, em certo sentido, a regulação é uma síntese delas.

Embora não haja perfeita identidade entre todas as noções, é nítido que a regulação é informada pelas idéias que lhe antecederam, não sendo criada ao largo de um referencial teórico precedente. A regulação visa a dar resposta às falhas evidenciadas em relação ao poder de polícia (baldo de um sentido prestacional) e ao serviço público, em sentido amplo

\footnotetext{
${ }^{222}$ MELLO, Celso Antonio Bandeira de. Curso..., p. 632-633.
} 
(associando a ele notas de eficiência e funcionalizando a posição de particulares). Esta perspectiva de continuidade, sem dúvida, merece ser destacada para a compreensão do fenômeno.

\subsection{FUNÇÃO DE REGULAÇÃO E A CONSTITUIÇÃO DE 1988 (FUNÇÃO NORMATIVA, EXECUTÓRIA E DE COMPOSIÇÃO DE CONFLITOS)}

Visto o conceito de regulação, importa assinalar a definição da existência de tal função na Constituição e o que daí se infere acerca dela.

A constituição alude, fundamentalmente, à regulação no seu art. 174, caput, que dispõe: "Como agente normativo e regulador da atividade econômica, o Estado exercerá, na forma da lei, as funções de fiscalização, incentivo e planejamento, sendo este determinante para o setor público e indicativo para o setor privado."

É na locução "agente regulador" que está contido o fundamento constitucional evidente da função regulatória a ser exercida pelo Estado no sentido de promover as missões a si reservadas no plano econômico-social. Ainda, em outras passagens a Constituição se vale da expressão "órgão regulador" impondo a criação de estruturas aptas a atuar em determinados setores específicos da atividade econômica, como as telecomunicações (art. 21, XI) e petróleo (art. 177, $\S 2^{\circ}$, III). A alusão a entes "reguladores" impõe o reconhecimento de que estas estruturas devem desenvolver função regulatória, sujeitando-se aos termos já vistos.

Antes, todavia, de se esmiuçar quais as contingências de a Constituição ter previsto expressamente uma função regulatória é de se retomar qual o conceito de função em direito público e o que daí se infere.

Função, adverte Celso Antônio Bandeira de MELLO, existe tanto em relação ao Direito Privado quando ao Direito Público, sendo típica do direito público e meramente acidental no direito privado, estruturado esse ramo, fundamentalmente, ao influxo da autonomia da vontade (que deixa os sujeitos livres na busca dos objetivos que reputar mais convenientes). ${ }^{223}$ Faz-se presente essa figura toda vez que o direito imputa a alguém a atuação

\footnotetext{
223 Anota o prestigiado publicista acerca do tema: "Função existe em direito, tanto na esfera do direito privado,quanto na província do direito público; só que domina totalmente a seara do direito público, e aparece eventualmente no campo do direito privado." (MELLO, Celso Antonio Bandeira de. Discricionariedade e Controle Jurisdiciona. 2. ed. São Paulo: Malheiros, 2001, p. 14.)
} 
em face de interesses que não são os seus e sim os de terceiro (em relação ao agente), estruturando a competência reconhecida a alguém em face do atendimento de finalidades que não são as suas.

Conceitua o citado autor o que vem a ser função:

Em Direito, esta voz função quer designar um tipo de situação jurídica em que existe, previamente assinalada por um comando normativo, uma finalidade a cumprir e que deve ser obrigatoriamente atendida por alguém, mas no interesse de outrem, sendo que, este sujeito - o obrigado - para desincumbir-se de tal dever, necessita manejar poderes indispensáveis à satisfação do interesse alheio que está a seu cargo prover. ${ }^{224}$

Ou, na dicção mais sintética de Renato ALESSI: "función es el poder concebido en relación con la realización de determinados intereses."225

Em uma primeira aproximação com o tema, percebe-se que a idéia de função é exatamente oposta a de autonomia, toda a figura se estrutura em vista de um interesse de um terceiro. No direito privado, o exemplo mais evidente de função é o mandato, em que o outorgado atua, na exata medida dos poderes que lhes são conferidos, bem como no exclusivo interesse do seu constituinte, sendo desviada qualquer atuação que não se cinja a este desiderato. A regra, contudo, no direito privado é a busca pelos indivíduos de seus próprios objetivos.

No Direito Público, ao contrário do Privado, só se concebe a atuação estruturada sob o aspecto funcionalizado. Didaticamente, os Poderes Públicos só atuam em vista de interesses que não lhe são próprios. Aliás, não poderia ser diferente tendo em vista o princípio republicano que impõe que todo poder emana do povo e em seu nome é exercido (cf. art. $1^{\circ}$, parágrafo único). ${ }^{226} \mathrm{O}$ exercício de qualquer atribuição pública pressupõe o atendimento a finalidades que não integram a esfera de domínio de quem as exerce, estruturando-se a partir

\footnotetext{
${ }^{224}$ Idem.

${ }^{225}$ ALESSI, Renato. Op. cit. p. 184.

${ }^{226}$ Para estudo mais aprofundado, consulte-se obra clássica de Geraldo ATALIBA: República e Constituição, 2. ed. São Paulo: Malheiros, 2001. Desta obra, calha citar as seguintes passagens: "A república, tal qual plasmada pelos sucessivos constituintes brasileiros, traduz-se num conjunto de instituições cujo funcionamento harmônico visa a assegurar, da melhor maneira possível, a eficácia de seu princípio básico, consistente na soberania popular. (...) Três princípios devem ser considerados como fulcro em torno do qual se ergue o edifício das instituições republicanas, no direito positivo brasileiro, operando como suas premissas básicas. Ao mesmo tempo ele é serviente dos valores neles encerrados, no contexto de uma relação indissociável de recíproca vocação. São com igual importância os princípios da legalidade, da isonomia e da intangibilidade das liberdades públicas". (Ibidem, p. 89;119.)
} 
dessa idéia elementar todo o regime de atuação de quem esteja a exercer função pública (inclusive, sujeitando particulares se investidos em missões dessa ordem).

Dessa estruturação do atuar dos que desempenham atividades públicas em torno da idéia de função, é que decorre a concepção do regime jurídico administrativo (bem como da própria atividade política ou de governo), que deve refletir, fielmente, esse compromisso com o atendimento de finalidades de terceiros. Qualquer que seja a manifestação de atuar dos poderes constituídos, ela expressa a idéia de função, não se exaurindo no mero exercício de prerrogativas em prol de interesses outros que não os da coletividade. ${ }^{227}$

Da estrutura funcional do atuar da Administração alguns elementos podem ser colhidos, de modo a compreender-se quais as contingências de se atuar sobre este influxo. Celso Antônio Bandeira de MELLO, encarece que quem labora ao sabor desta lógica não tem a si reconhecidas capacidades de atuação em prol de seus interesses (recondutíveis à noção de "poderes"), toda atribuição para agir organizada em função de outrem assume o caráter de dever. Não há, nestes casos, como atuar ou deixar de atuar uma determinada potência em vista de cumprir os interesses de terceiro, o agir se impõe como dever. Daí que não se cogita de "poderes" de ordem alguma e sim em deveres; isto, porque, todas as capacidades de ação (exorbitem ou não do direito comum) são atuadas em vista da satisfação dos interesses de terceiros. Toda margem de atuação que se reconhece ao agente é ancilar e instrumental ao atingimento dos interesses que são tutelados. ${ }^{228}$ Parece que a cogitação acerca dos meios pelos quais se exerce uma atribuição funcional é um dos vértices implicados neste conceito, todavia, longe está de ser o único.

O tema não se esgota aí. Outras decorrências necessariamente surgem de ao se cogitar da idéia de função, além da atuação ao influxo de um dever.

Primeiramente, é de se cogitar quais os fins que devem ser perseguidos ao se pensar em uma função. A concepção de quais são as finalidades a serem atingidas integra a própria idéia de função. De nada adianta explicar como vai ser atuada uma determinada atribuição de prerrogativa se não estiverem claros os objetivos a serem atingidos. A finalidade que justifica

\footnotetext{
${ }^{227}$ Como já visto, o maior sistematizador dessa idéia é Renato ALESSI que vais condicionar todo o exercício de poder ao atendimento do interesse público primário (i.e. ao interesse coletivo). Para tomar trato com a concepção do autor consulte-se sua obra. Op. cit., p. 180-225.

${ }^{228}$ MELLO, Celso Antonio Bandeira de. Discricionariedade..., p. 14-16.
} 
a atribuição de uma regra de competência é elemento essencial à compreensão da lógica funcional.

Neste particular, e retomando pontos já entrevistos ao longo da exposição do capítulo anterior, é de se destacar que, atualmente, uma das características que marca a atuação jurídica atual é de não raro se estar diante de interesses fracionados e não uniformes. Se, anteriormente, a finalidade da atuação do Estado era delimitada com simplicidade pelas normas jurídicas, hoje não há a possibilidade em muitos casos de se inferir com precisão quais os fins a serem satisfeitos. Não raro, vários interesses dignos de tutela (como o meio ambiente e o desenvolvimento econômico, por exemplo) parecem estar em constante tensão, impondo que a Administração componha essa carga de indeterminação e defina, caso a caso, qual o interesse que deva prevalecer em uma determinada situação concreta. As finalidades a serem atingidas então, muitas vezes, não estão postas de maneira clara, sendo necessário um esforço prévio para definir quais os efetivos valores a serem implementados em um determinado caso concreto.

Desde o ponto de vista então da definição dos fins a serem satisfeitos por intermédio de uma lógica funcional há dinamicidade em relação a eles, não mais se concebendo, usualmente, atribuições estáticas. Não há um fim auto-evidente, perfeitamente pré-determinado apenas aguardando para ser atuado.

O Estado Pós-Social implica em que os próprios fins em concreto sejam determinados previamente pela Administração, com base em amplas e fluídas parametrizações legais, em vista dos diferentes interesses a serem conciliados em um determinado caso.

A regulação essencialmente lida com este tipo de estrutura devendo então se cogitar quais são as finalidades a serem alcançadas e como desvelá-las na medida em que este não é um processo auto-evidente de mera pesquisa legal. Mais e mais, os diplomas legais atribuem fins genéricos que devem ser concretizados, em vista de uma lógica que permita a ampla participação dos interessados, determinando-se os fins efetivos em vista de um procedimento.

Em relação aos meios, obviamente a estrutura funcional implica em que haja o reconhecimento de deveres a serem satisfeitos, não se esgotando as prerrogativas em si, sendo elas concebidas em vista do interesse da sociedade. Há mais.

A atribuições de fins fluídos, reflete-se na flexibilidade dos meios de se atuar a função regulatória, o que é apontado como uma característica dos modelos jurídicos atuais. Neste 
sentido a função regulatória implica em manejo não só de capacidade para atuar a lei, mas também de normatizar, em abstrato, condutas e compor litígios advindos do seu exercício. Neste sentido, é que se aponta que a regulação conta com competências "quase" legislativas e judiciais. Não se esgota a sua técnica apenas na atuação da lei no sentido de aplicá-la, há a necessidade de estabelecer genéricos e abstratos de modo a garantir-se o atendimento dos fins postos legislativamente, bem como de compor conflitos, ainda que sem a nota de definitividade típica da jurisdição, decorrentes do seu exercício.

Outra nota a ser destacada então, como inerente a essa idéia de flexibilidade, é a maior margem de atuação da sociedade, o que não raro leva a uma utilização, desde que responsável, de formas de direito privado e esquemas que privilegiam a indução ao revés da coação. É tônica em relação aos meios utilizados no exercício da função regulatória a utilização de vias consensuais como modo de se atingirem objetivos públicos, sem o recurso à autoridade. Isto, claro, sem se dispensar o arcabouço sancionatório tradicional, em casos que exijam recursos a tais finalidades.

Não se perca de mira que a regulação, consoante exposto, legitima-se pelo atendimento nas melhores condições possíveis, dos fins estabelecidos pelas cúpulas diretivas do Estado. A idéia de eficiência integra o conceito de regulação, o que implica uma avaliação mais severa dos meios pelos quais essa função vem a ser atuada. A idéia de função não permite que a avaliação do atendimento satisfatório desses fins fique, apenas e tão só, a cargo das autoridades dotadas de atribuições desta natureza. É necessário compartilhar avaliações desta ordem com a própria sociedade, destinatária das atuações do Estado, que não mais tem o monopólio de analisar unilateralmente o sucesso ou insucesso de tais atividades.

Isto opera importantes ponderações no que toca à estrutura de controle do exercício da função regulatória. Primeiramente, contudo, importa destacar que a idéia de controle é inerente à própria idéia de função. Em uma estrutura voltada ao atendimento de interesses de terceiros, em que quem está a manejar as prerrogativas não o faz em seu benefício, impõe-se reconhecer a necessidade de controles institucionalizados em dois níveis. O primeiro, no sentido de se aferir se as finalidades estão sendo atendidas a contento, ou seja, se a atuação corresponde aos fins postos. $\mathrm{O}$ segundo, com o manejo adequado das prerrogativas que são conferidas ao agente. Função, onde quer que haja, impõe a necessidade de controle severo. Aquele que cura de interesses que não são seus deve ter sua atuação contrastada com padrões 
de controle, de modo a manter-se hígido o arranjo concebido em face de terceiro. De nada adianta supor a existência de uma função, se não houver meios de aferir se ela está orientandose aos seus fins legítimos.

Assume transcendental relevo a idéia de controle, em especial, exercido por aqueles que se encontram tutelados pelo seu exercício. Nesta linha, a idéia de atuação eficiente implicada à regulação impõe ainda um controle mais severo tanto dos meios utilizados (que devem respeitar a esfera inviolável dos indivíduos) quanto, fundamentalmente, do atingimento dos fins perseguidos. A idéia de que a regulação conjuga em seu bojo aspectos prestacionais e afeitos à idéia de limitação de direitos, impõe o controle nestes dois planos.

Tais dimensões ficam implicadas, necessariamente, no conceito de função. Função predica identificação dos fins, eleição dos meios idôneos para implementá-las e controle em relação a ambos.

Visto tais pressupostos estipulativos, volta-se à análise do Texto Magno, desvelando a questão da função regulatória em seu bojo.

A Constituição reservou ao Estado, em específico no capítulo reservado à Ordem Econômica, mas também ao longo de todo o seu texto, a missão de promover a todos uma existência digna, conforme os ditames da justiça social, estribada na valorização do trabalho humano e na livre iniciativa (cf. art. 170, caput).

Tais valores devem ser buscados observando uma vasta pauta de diretrizes postas pelo Texto Magno, em especial, pelo próprio art. 170 em seus incisos, a saber:

soberania nacional; propriedade privada; função social da propriedade; livre concorrência; defesa do consumidor; defesa do meio ambiente, inclusive mediante tratamento diferenciado conforme o impacto ambiental dos produtos e serviços e de seus processos de elaboração e prestação; redução das desigualdades regionais e sociais; busca do pleno emprego; tratamento favorecido para as empresas de pequeno porte constituídas sob as leis brasileiras e que tenham sua sede e administração no País.

Em sendo assim, os referidos valores devem ser objetivos de toda atuação econômica (seja pública, seja privada), havendo verdadeiro dever do Estado implementar tais valores, sem excluir a atuação dos particulares. Mesmo consagrando a liberdade de os particulares explorarem todas as atividades que não estejam sujeitas a vedações legais (seja por serem serviços públicos, seja por serem ilícitas) essa liberdade não é plena e é capaz de conhecer temperamentos. Vale dizer, a liberdade pode ser funcionalizada. 
A função regulatória tem abrigo exatamente na necessidade de o Estado promover estes valores de modo efetivo, consoante se infere do art. 174 da Constituição. É na implementação destes objetivos que reside o nicho da função regulatória.

Como visto, no mister de implementá-los cumpre ao Estado ponderar os diversos valores envolvidos, buscando efetivá-los ao máximo em vista das pautas estabelecidas na Constituição. Para tanto, deve se valer das mais diversas formas de atuação, tudo em vista e orientado à concretização de tais valores. Há um dever de atuação do Estado para implementar estes valores, arbitrando os conflitos potenciais acerca dos reais objetivos a serem alcançados, toda vez que o funcionamento ordinário das atuações dos poderes públicos não estiver apto a dar cumprimento às pautas constitucionais (que devem ser esmiuçadas por normas infraconstitucionais).

É em vista de tais objetivos que se concebe uma forma de atuação própria de atuação do Estado sobre os domínios econômicos (que obviamente também são sociais) e não em face de qualquer tecnicidade referente a alguma matéria ou em vista de interesses privados. Tais concepções, à luz da Constituição, devem ser rechaçadas de modo veemente. Mais ainda, a existência de centros dotados de independência para manejar competências regulatórias não desnatura os objetivos maiores da regulação, plasmados na Constituição da República de $1988 .^{229}$

Aliás, analisando o tema das Agências Reguladoras, adverte Eros Roberto GRAU que elas não constituem substantiva alteração nas categorias conhecidas de longa data pelo Direito Administrativo Brasileiro. ${ }^{230}$ Isso impõe que o tônus dos estudos sobre o tema deve estar na própria função regulatória, e não em quem porventura a desenvolva. $\mathrm{O}$ viés subjetivo depende da compreensão do sentido objetivo.

Em seu lócus constitucional, a regulação orienta-se então à promoção de valores socialmente relevantes, impondo a atuação do Estado com vista a atendê-los. Exige-se uma atuação suplementar do Estado de modo a orientar, privilegiando os valores constitucionais, o desenvolvimento nacional.

\footnotetext{
${ }^{229}$ Adverte Calixto SALOMÃO FILHO que a discussão acerca da regulação deve focar-se na tentativa de elaboração de uma teoria geral que a explique à luz do sistema jurídico brasileiro, e não se foque exclusivamente nas agências que a implementam em alguns setores. Nesta linha, a advertência do referido professor: "Em primeiro lugar é preciso observar que o debate sobre agências sempre será instrumental em relação à discussão dos objetivos a serem por elas perseguidos. Assim nunca deverá compor o centro do debate (o que vem ocorrendo em tempos recentes).” (in Regulação..., p. 61.)

${ }^{230}$ GRAU, Eros Roberto. As Agências..., p. 25-28.
} 


\section{ANÁLISE DA REGULAÇÃO ENQUANTO ESTRUTURA FUNCIONAL}

Como visto, a regulação é tarefa estatal que constitui exercício de função administrativa que, todavia, não se amolda à perfeição nas categorias que tradicionalmente explicam as manifestações concretas do exercício das competências da Administração Pública. Em síntese, é uma categoria que se vale de elementos hauridos da noção de poder de polícia bem como também na de serviço público. Grosso modo, o conceito de regulação produz uma síntese entre ambas as noções que lhe são anteriores, traduzindo-se em um modo de alcançar objetivos prestacionais sem apelar ao controle estatal direto de atividades.

Como exercício de uma função, a regulação pode ser analisada tendo em mira os elementos usualmente suscitados por essa forma de atuação jurídica.

Nesta linha, pois, há de se considerar quais são (i) os objetivos da regulação; (ii) os meios pelos quais tais desideratos podem ser atingidos e (iii) como controlar o exercício das competências regulatórias. Analisar o tema sobre esses três tópicos é o que se buscará fazer a seguir.

Contudo, ainda antes de analisar a regulação sobre o influxo funcional algumas advertências metodológicas devem ser feitas.

Primeiramente, como já se ressaltou, o presente trabalho não visa a colocar em mira um quadrante específico que esteja sujeito à regulação estatal. Todas as referências específicas ora coligidas tinham por finalidade imediata demonstrar a pertinência de algum elemento geral posto em evidência e não cuidar de nuances de certo campo de atuação da regulação. Tal corte metodológico impõe consequiências bastante evidentes no esforço que ora se pretende empreender. Objetivos, formas de atuação e controle serão analisados também sobre os aspectos gerais, que se reputam peculiares ao exercício da regulação enquanto categoria jurídica dotada de alguma sistematicidade. Esforços particularizados além de poder dotar de espessura as cogitações gerais a seguir lançadas, podem eventualmente acrescer elementos próprios a cada setor regulado. Privilegiar-se-á a visão panorâmica acerca do tema.

Outra ressalva absolutamente importante diz com o fato de que os temas a serem tratados - por ser todo o direito administrativo estruturado ao influxo de uma lógica funcional - são objeto de amplas cogitações pelos estudiosos do Direito Administrativo. Temas como a 
importância da finalidade pública para a prática de atos administrativos, os meios pelos quais se exercem as diferentes tarefas administrativas e como se controla a Administração Pública são a matéria que, por excelência, ocupa a doutrina brasileira. Novamente, impõe-se, então, proceder a um corte metodológico em relação ao trato do assunto. Destaque-se, mais uma vez, que o tema será tratado naquilo que, crê-se, a função de regulação tem de distinto. Ou seja, que seja capaz de suscitar algum grau de afastamento de como tais temas são tratados de usual pelo Direito Administrativo.

\subsection{FINALIDADES DA REGULAÇÃO}

Como já dito, a idéia de função só se concebe em vista de uma finalidade a ser atingida em favor de um terceiro. As finalidades a serem atingidas com a regulação são, então, imprescindíveis para a compreensão do exercício desta função. Já se assinalou também que os objetivos maiores estão contidos na Constituição que institui, ainda que de maneira ampla, uma pauta de valores a ser atingida, dotada, contudo de uma tensão inerente. Todavia, tal abordagem ainda é muito genérica e carece de explicitações mais detidas para relacionar regulação com o atingimento de resultados socialmente desejados.

Assim, faz-se necessário proceder a uma análise mais detida acerca dos objetivos a serem atingidos pelo exercício da função regulatória. O tema não é objeto de análise usual na doutrina pátria, que dilui o assunto na invocação genérica a um interesse público a ser atingido pela atuação estatal. Uma exceção à regra é o pensamento de Calixto SALOMÃO FILHO, que se lançou especificamente a analisar, desde o ponto de vista jurídico, quais são as missões a serem atingidas pela regulação. Neste sentido, o autor associa expressamente regulação ao desenvolvimento econômico do país. ${ }^{231}$

Buscando explicar sua concepção, o referido autor enuncia três princípios no seu sentir fundamentais para promoção do desenvolvimento (e, pois, inerentes à regulação): (i) adoção de ações redistributivas pelo Estado; (ii) medidas que promovam a difusão do conhecimento econômico pela sociedade inclusive, a depender da hipótese adotando-se meios coercitivos e (iii) estímulo à cooperação entre particulares, reduzindo os custos na iteração entre eles. Tais

\footnotetext{
${ }^{231}$ Ibidem, p. 29-63.
} 
princípios estariam na base da implementação jurídica do desenvolvimento, missão última reservada à regulação, segundo sustenta o autor em obra pioneira. ${ }^{232}$

Outro doutrinador que busca de modo expresso analisar quais os efetivos objetivos da regulação é Floriano Peixoto de Azevedo MARQUES NETO. Em seu pensamento, a função regulatória tem por missão institucional acomodar de modo harmônico e efetivo os diferentes interesses contrapostos na sociedade.

Há impossibilidade de reconhecer um interesse público unívoco, perfeitamente determinado tal ausência induz à necessidade de provas de instâncias de atuação estatal que permitam acomodar de modo harmônico a promoção de tais objetivos. Colhe-se do pensamento do autor, a seguinte passagem que ilustra sua concepção:

Não se coloca mais para o Direito Administrativo apenas o desafio de regrar a atividade administrativa de molde a proteger o administrado do Poder Público - função que lhe acometera o modelo liberal. Tampouco se restringe a seara administrativa ao temário da forma de implementar e operacionalizar as políticas públicas, as ações sociais, ou, mesmo, prestar serviços públicos - funções que foram agregados ao Direito Público pelo Advento do Estado Intervencionista (ou de Bem-Estar Social) (...) Impende, por um lado, verificar como a Administração pode assumir um papel prevalecente de mediador das relações privadas que emergem com força determinante nas diversas esferas da vida social. Trata-se aqui do campo da mediação de interesses. ${ }^{233}$

Em vista desse objetivo de compatibilização da multicidade de demandas que caracteriza a fragmentariedade do interesse público, os instrumentos concebidos para a atuação estatal são vários. Todos eles, contudo, orientam-se à função de mediar os conflitos sociais decorrentes da ausência de correspondência entre os diversos interesses dos atores da cena social.

É necessário buscar uma compreensão mais profunda do tema perquirindo como da multicidade de interesses conflitantes pode haver a definição de um objetivo para a regulação.

\footnotetext{
${ }^{232}$ Tércio Sampaio FERRAZ JÚNIOR ao associar o poder normativo das Agências Reguladoras ao princípio da eficiência debruça-se sobre fixar os limites desse fenômeno. Para tanto, não se furta a produzir um rol de princípios que seriam os objetivos da regulação. São eles: (i) uma regulação eficiente deve levar a uma distribuição de renda politicamente ótima; (ii) políticas que impliquem no decréscimo da riqueza total disponível para a redistribuição devem ser evitadas; (iii) regras regulatórias devem ser dotadas de transparência; (iv) a regulação deve se praticada por autoridades dotadas de mandato; (v) o Poder Judiciário tem ampla capacidade de rever o mérito das decisões regulatórias; (vi) eficiência é fundamento tanto dos atos vinculados como dos discricionários havendo um ônus de atingir as finalidades perseguidas pela regulação e (vii) deve se prever a participação dos cidadãos no exercício da regulação. (in O Poder..., p. 294 e 295). Sobre um certo aspecto o autor aproxima-se da idéia de Calixto SALOMÃO FILHO, em especial, ao associar a regulação notas redistributivas.

${ }^{233}$ MARQUES NETO, Floriano Peixoto de Azevedo. Regulação..., p. 194-195.
} 
Parece, em relação às pautas a serem implementadas pelo exercício da regulação, que a Constituição não se limita em impor o desenvolvimento econômico como objetivo da atuação estatal. Em se analisando a multicidade de valores salvaguardados pelo Texto Constitucional, o desenvolvimento econômico não é o único elemento a ser perseguido. Aliás, em situações limite pode se opor uma concepção em prol do desenvolvimento econômico a outros valores a serem garantidos pela atuação estatal ( $v . g$. a defesa do meio ambiente). É dizer, a própria idéia de desenvolvimento econômico pode se apresentar conflitando com outros valores que se apresentam como socialmente relevantes.

Com efeito, não há um (ou "o") objetivo a ser alcançado, apenas e tão só, como bem se infere do pensamento de Floriano Peixoto de Azevedo MARQUES NETO. Há, em verdade, uma miríade de interesses a serem sopesados e aplicados em um processo de definição dos elementos a prevalecer em um determinado caso, não se podendo conter a multicidade de elementos a serem implementados em uma única fórmula verbal (como "direitos fundamentais", "interesse público" ou "desenvolvimento econômico"). Com efeito, como veio de se ver, a regulação implica em dar satisfação efetiva a interesses diversos que guardam relativa incompatibilidade entre si.

O desenvolvimento econômico é um fim a ser implementado pela regulação, contudo, não é o único interesse digno se ser perseguido. Regulação, diz com a gestão eficiente de diversos fins a serem ponderados e atuados e afeitos à esfera de interesses de diversas pessoas.

A partir disso, parece mais correto o pensamento de Floriano Peixoto de Azevedo MARQUES NETO ao reconhecer que a regulação diz com essa indeterminação de fins préestabelecidos. Neste sentido é que destaca o autor que a regulação lida, necessariamente, com fins indeterminados a serem arbitrados em vista das situações concretas. ${ }^{234}$

Todavia, mesmo no pensamento de Calixto SALOMÃO FILHO tem-se concepção que se adapta à indeterminação prévia de fins no que toca a como deve ser implementada a função de regulação. Com efeito, a invocação de um objetivo uno parece mais obedecer a fins didáticos do que servir de vetor único à compreensão do fenômeno da regulação pelo referido autor.

\footnotetext{
${ }^{234}$ Tal posição é também reconhecida por Giovani R. LOSS que dedicou um artigo a buscar lançar algumas luzes acerca do que pode vir a ser uma teoria da regulação. Contribuições à Teoria da Regulação no Brasil: Fundamentos, Princípios e Limites do Poder Regulatório das Agências, in O Poder Normativo das Agências Reguladoras, coord. Alexandre Santos ARAGÃO, Rio de Janeiro: Forense, 2006, p. 159-162.
} 
A definição do conteúdo da regulação, segundo o autor, dá-se por meio de uma lógica procedimental que deve considerar os diversos objetivos em tensão no jogo econômico. Sobre um certo sentido, vencida a indeterminação semântica, o pensamento dos professores Floriano Peixoto de Azevedo MARQUES NETO e de Calixto SALOMÃO FILHO se complementam, ambos se fundando no reconhecimento da impossibilidade de se atribuir um tarifamento de finalidades no que toca ao exercício da regulação. ${ }^{235}$

Defende Calixto SALOMÃO FILHO que os processos de desenvolvimento econômico devem se pautar em uma lógica de devido processo em matéria econômica ("due process"), que possibilite acesso a todos os interessados à definição das pautas regulatórias. Aliás, a abordagem do autor não se resume à regulação alcançando também o direito concorrencial. ${ }^{236-}$ 237 Sem dúvida, a concepção institucional dos conceitos de regulação e de concorrência constitui uma das notas mais originais de seu pensamento e merece análise mais detida.

No pensamento do autor, a tutela do Estado sobre a ordem econômica (seja pela via da regulação seja pela via da defesa da concorrência) deve se orientar a permitir que as próprias forças que agem no mercado descubram, por meio de um processo de descoberta e, pois, de conhecimento, as condições reputadas adequadas por cada agente econômico. Tem-se aí um processo de produção de conhecimento econômico que necessita inexoravelmente de efetiva possibilidade de os atores econômicos dele participarem. É o jogo econômico como instituição aberta e plural que é o bem jurídico a ser salvaguardado pela atuação do Estado na economia.

A importância do conhecimento no exercício da regulação é também encarecida por Santiago Muñoz MACHADO que afirma que o exercício da regulação pressupõe a produção de conhecimento econômico e sua difusão com os diversos atores do mercado. Demonstrando esta premissa narra a existência de experiências regulatórias que se limitaram, apenas e tão só, a coligir informações relevantes e disponibilizá-las ao mercado (é o caso das chamadas

\footnotetext{
${ }^{235}$ Afirma Calixto SALOMÃO aproximando os entendimentos: "Essa mudança no foco da preocupação - da busca de um objetivo determinado e pré-jurídico para a garantia da efetiva correção e da lealdade da integração dos vários agentes econômicos no mercado e de sua igualdade material em termos concorrenciais - é uma resposta à questão do fundamento da regulação (due process clause em matéria econômica (...) Em particular, é necessário compatibilizar tal forma de regulação com princípios constitucionais díspares como a livre iniciativa e a justiça social (artigo 170 da Constituição Federal)." (in Regulação..., p. 30).

${ }^{236}$ Aprofundar o pensamento do autor em Direito concorrencial - as condutas, São Paulo: Malheiros, 2003.

${ }^{237} \mathrm{O}$ pensamento do autor acerca do tema em linhas mais gerais já tinha sido exposto no estudo Globalização $e$ Teoria Econômica do Conhecimento, SUNDFELD. Carlos Ari; VIEIRA, Oscar Vilhena. (coord.) Direito Global. São Paulo: Max Limonad, 1999, p. 259-269. Neste artigo a uma explicitação mais pormenorizada das premissas adotadas para o autor para abordar instituições como regulação e concorrência de modo institucional.
} 
"sunshine commissions" americanas cujo escopo era exclusivamente a produção de informações acerca de certos mercados regulados) com efeitos tidos por superiores a outros instrumentos regulatórios. ${ }^{238}$

A própria possibilidade de acesso ao processo de interação que produz o conhecimento econômico é, no pensamento de Calixto SALOMÃO FILHO, um bem jurídico dotado de valoração específica e que induz à necessidade de tutela jurídica (justificando a atuação estatal sobre a economia). Mais ainda. Essa tutela não se dá de modo individualizado, há um descolamento desse interesse das esferas individuais, devendo ser objeto de salvaguardas jurídicas coletivas. Vale dizer, o direito ao acesso ao jogo de produção de conhecimento econômico não interessa apenas aos sujeitos individualmente considerados, mas possui uma dimensão jurídica que perpassa suas esferas de interesse. ${ }^{239}$

Assim, no pensamento do autor o desenvolvimento é garantido pela possibilidade de acesso a todos os interessados ao mercado de modo a fazer valer seus interesses. Desenvolvimento econômico assume então a acepção de resultado desse jogo e não um interesse previamente tarifado.

O encontro dessa infinidade de interesses e a livre articulação entre eles é que faz emergir o ponto ótimo (desde a perspectiva social) buscado no exercício das atividades econômicas.

Assim, na linha teórica que se adotou importa assinalar que não há possibilidade de se identificar o exercício da função de regulação com nenhuma finalidade definida a priori. A necessidade de manter as atividades econômicas funcionando em padrões de adequação implica em que não se busque tarifar os objetivos buscados pelo exercício dessa atividade administrativa. ${ }^{240}$ Isso não se faz possível sem o apelo a rótulos absolutamente genéricos que não se prestam a desvelar a racionalidade ínsita ao exercício da regulação. ${ }^{241}$

\footnotetext{
${ }^{238}$ Ilustrando o entendimento do autor: "En los análisis sobre las funciones de las comisiones reguladoras americanas no es infrecuente encontrar la afirmación de que aun actualmente las autoridades más eficaces son justamente las que reposan, en alguna medida, sobre el modelo de la 'regulación pela información"'. (MACHADO, Santiago Muñoz. Op. cit., p. 1198.)

${ }^{239}$ SALOMÃO FILHO, Calixto. Direito..., p. 17-20.

${ }^{240}$ Sobre o tema, manifesta-se Paulo Todescan Lessa MATTOS: “quando a Administração Regula e exerce o que é qualificado como capacidade normativa de conjuntura, ela não está, na prática, executando uma (no sentido de única) política econômica definida no texto constitucional ou em lei. A Administração está definindo o conteúdo econômico das normas segundo dois fatores, quais seja, (i) os interesses dos agentes que estão em jogo; e (ii) a dinâmica própria (conjuntural) de cada setor da economia ou relação econômica a serem regulados." Autonomia Decisória, Discricionariedade Administrativa e Legitimidade da Função Reguladora do
} 
Ratificando o que ora vai alegado tem-se a lição de Diogo de Figueiredo MOREIRA NETO acerca da implementação da função regulatória:

\begin{abstract}
Não se trata, portanto, da aplicação de uma definição legal vinculadora de certo interesse público específico (norma legal densificadora), nem, tampouco, a aplicação de uma definição administrativa discricionária (norma administrativa densificadora) de um interesse público específico, integrado pelo administrador por subsunção, mas da definição administrativa de quais interesses específicos, públicos e privados, deverão se atendidos e de como deverão sê-lo (regulação densificadora), nas relações submetidas à função regulatória, um resultado que não estará predeterminado nem na lei nem no regulamento, senão que deverá ser deduzido dos fatos, pelo exercício qualificado, negociado e ponderado dessa função pelos órgãos reguladores. ${ }^{242}$
\end{abstract}

Em especial, é de se dizer que embora a regulação tenha surgido no momento histórico em que se efetivavam as privatizações e que em grande parte o seu exercício tinha por escopo imediato assegurar a existência de concorrência em mercados antes explorados pelo Estado, ela não se reduz apenas a esse objetivo. Nada obstante a introdução de concorrência para criar mercados onde antes eles não existiam seja uma possibilidade de utilização da regulação é de se ver que ela não é a única. Na atual conjuntura - especialmente na Europa - parece haver consenso de que a concorrência tem o mérito de gerar produtos e serviços em padrões mais satisfatórios para os que deles necessitam e de que é desejável substituir a presença do estado por mercados privados. Isso levou a que em cenários de privatização a regulação fosse introduzida como meio de instituição da concorrência antes inexistente, criando-se mercados no vácuo deixado pela retirada do Estado. ${ }^{243}$ Embora a assertiva esteja correta e proceda desde o ponto de vista histórico ela não é sólida o bastante para identificar o objetivo da regulação apenas com a criação de mercados em regime de concorrência em substituição ao Estado.

Quando menos, a crescente existência de regulação em mercados que nunca foram considerados públicos (v.g. saúde suplementar) demonstra a inviabilidade de se reduzir o objetivo da regulação à introdução de concorrência em mercados recém criados.

\footnotetext{
Estado no Debate Jurídico Brasileiro. ARAGÃO, Alexandre dos Santos (coord.). O Poder Normativo das Agencias Reguladoras. Rio de Janeiro: Forense, 2006, p. 352.

${ }^{241}$ Nesse sentido a advertência de Giovani R. LOSS: “(...) qualquer regra geral que busque delimitar a intensidade, abrangência e forma da regulação estatal é inevitavelmente falha (...).” (Op. cit., p. 159.)

${ }^{242}$ MOREIRA NETO, Diogo de Figueiredo. Mutações..., p. 392;393.

${ }^{243}$ Essa parece ser a opinião de Gaspar Ariño ORTIZ ao propor seu modelo de regulação pela concorrência.. Nele, o autor fixa dois princípios que seriam comuns a todos os campos regulados: desintegração vertical (unbundling) de atividades, cindindo atividades antes unas em diversas atividades e transparência informativa (Principios de Derecho Publico Economico: modelo de Estado Gestio N Publica, Regulacion Economica. 3. ed. Madrid: Editorial Comares, 2004. p. 562-563).
} 
Outra idéia que parece não se sustentar é que regulação, necessariamente, deva coincidir com o interesse exclusivo dos consumidores. Por vezes, a lógica regulatória impõe a proteção a interesses que não se coadunam com a máxima satisfação do interesse dos consumidores. Por exemplo, nos casos em que há obrigações de universalização imposta a operadores econômicos tais pautas não podem ser frustradas pelas demandas de redução de preços postas pelos consumidores. Embora o interesse dos consumidores deva ser considerado sendo digno da mais ampla tutela jurídica, pois se cuida de princípio constitucional da ordem econômica, ele não deve ser tomado de modo absoluto. ${ }^{244}$

Insista-se, a regulação se caracteriza, exatamente, por não eleger aprioristicamente os objetivos a serem por ela implementados.

As cogitações ora postas, bem demonstram que os entes encarregados de produzir a regulação, ao serem submetidos ao encontro de diversas pretensões das mais dissonantes ordens, devem guardar uma posição alheia ao jogo de interesses.

Embora como visto não se possa prender o exercício da regulação a fórmulas fechadas devendo, ao revés disso, manter seu exercício permeável as mais diversas possibilidades de apresentação de demandas tidas por relevantes, é de se mencionar que a obtenção dessa finalidade depende de salvaguardas.

Em especial, o alcance desse escopo depende da garantia da imparcialidade do regulador em face dos interesses postos em conflito. O efetivo atendimento da necessidade de ponderar os diversos interesses em jogo depende, fundamentalmente, de que o exercício da função regulatória seja exercida sem identificar-se com nenhum deles. É pressuposto da ausência de finalidade previamente definida, a existência de independência do regulador em relação aos interesses postos em jogo.

A posição de independência da Administração impõe a alteração do papel usualmente reservado a ela como parte da relação por ela constituída. Exige-se a eqüidistância da autoridade que está exercendo a regulação, agudizando-se assim a idéia de imparcialidade no exercício da função administrativa.

Tal elemento inerente à função de regulação é que está na raiz das discussões acerca da independência nas agências reguladoras brasileiras, cujas leis instituidoras, ao cuidar do

\footnotetext{
${ }^{244}$ Para uma resenha da questão da proteção do usuário do serviço público, consulte-se o livro de Dinorá Adelaide Musetti GROTTI: O Serviço Público e a Constituição de 1988. São Paulo: Malheiros, 2003. p. 336376.
} 
chamado regime autárquico especial, buscam instituir por meio de um reforço de autonomia, especialmente em face dos centros decisórios do Executivo. As técnicas utilizadas são concebidas para conferir independências às autarquias de regime especial são, pois, garantias do exercício imparcial da atividade regulatória.

Como já afirmou Egon Bockmann MOREIRA:

\begin{abstract}
Essas distinções no regime das autarquias especiais visam precipuamente a conferir maior estabilidade, segurança e prestígio às decisões nos setores regulados, pretendendo assegurar que os atos lançados pelas agências sejam técnicos (não políticos). O instrumental jurídico põe-se à disposição dessa garantia e as especialidades das agências são, portanto, apenas um meio para se tentar assegurar a neutralidade regulatória. ${ }^{245}$
\end{abstract}

É inerência da ausência da assunção prévia de um interesse como seu que impõe à Administração, no exercício da função de regulação, uma posição de neutralidade. Isso, obviamente, novamente demonstra a parcial inadequação de se tratar a regulação com olhos nas categorias já sedimentadas no Direito Administrativo. O tema, aliás, mereceu precisa síntese de Paulo OTERO:

\begin{abstract}
Adoptando uma posição de terceiridade nas respectivas decisões, a Administração Pública aparece como um árbitro ou um simples garante das regras do jogo, tudo se passando como se ela não fosse parte nesse mesmo jogo, mostrando-se acima do conflito de interesses que lhe compete dirimir e, neste preciso sentido, a função administrativa acaba por comungar de uma das características tradicionais da função jurisdicional: o seu carácter de terceiridade. ${ }^{246}$
\end{abstract}

Assim a pesquisa dos objetivos da regulação nos conduz a um aparente paradoxo na medida em que a única finalidade que pode ser apontada para essa manifestação administrativa não é dotada de contornos precisos. Não há uma meta previamente posta para o exercício da regulação (tal como a instituição da concorrência ou ainda a defesa do consumidor). Há, sim, a necessidade de se manter o exercício da regulação aberto a diferentes influxos de modo a se conseguir ponderar os conflitos em tensão que são submetidos à Administração. É exatamente a abertura de fins e a caracterização como o lócus de encontro de pretensões diversas que caracteriza o exercício da regulação e constitui o que se poderia

\footnotetext{
${ }^{245}$ MOREIRA, Egon Bockmann. Os Limites à Competência Normativa das Agências Reguladoras. ARAGÃO, Alexandre dos Santos (coord.). O Poder Normativo das Agências Reguladoras. Rio de Janeiro: Forense, 2006. p. 176.

246 OTERO, Paulo. Legalidade e Administração Pública - O Sentido da Vinculação Administrativa à Juridicidade, Coimbra: Almedina, 2003, p. 325.
} 
apontar como uma finalidade sua. Qualquer tentativa de rotulação seria inadequada, ou seria por demais genérica e, pois, imprestável ou deixaria de fora elementos importantes a serem levados em conta pela regulação. Não há terceira hipótese.

Essa necessidade de garantia de neutralidade associada à regulação implica na cogitação de salvaguardas que mantenham o seu exercício longe dos interesses que devem ser arbitrados pelo regulador. A permeabilidade aos interesses em jogo deve ser garantida pela real imparcialidade do regulador que não pode assumir como seus quaisquer dos interesses em jogo. Deste modo, encarece-se o elemento de independência que deve ser reconhecido a quem exerce a regulação.

\subsection{MODOS DE EXPRESSÃO DA FUNÇÃO DE REGULAÇÃO}

Vistos os objetivos da regulação, é de se analisar por meios de quais expedientes essa função se desenvolve. Cuida-se de se analisar qual sorte de atuação está implicada na concretização da função de regulação.

Já se teve o ensejo de indicar que no exercício da regulação estão implicadas além da tradicional concretização ex officio de comandos normativos (inerente à atividade de administração) atuações ditas quase legislativas e quase judiciais. Tal concepção visa a destacar que as competências exercidas por aqueles que estão no desempenho de função regulatória não se esgotam na atividade que tradicionalmente se reconhece à Administração. ${ }^{247-248}$ A função de regulação agrega outras manifestações que usualmente não são tidas por tipicamente caracterizadoras da atividade de administração.

Importa destacar, contudo, que a atividade de regulação não rompe com a racionalidade inerente ao exercício da função administrativa. Embora certamente o exercício

\footnotetext{
${ }^{247}$ Neste sentido adverte Alexandre Santos ARAGÃO: “Como o conceito de regulação agrega o exercício de uma série de funções e poderes administrativos, é decorrência necessária que as agências reguladoras desempenhem uma série de distintas funções, o que chega mesmo a desafiar algumas formulações mais tradicionais da doutrina da separação dos poderes." (In Agências..., p. 316.)

${ }^{248}$ Floriano Peixoto de Azevedo MARQUES NETO desdobra esses núcleos em seis tarefas distintas: (i) competências normativas; (ii) competências adjudicatórias de emissão de comandos concretos; (iii) competências fiscalizatórias; (iv) competências sancionatórias; (v) competências arbitrais para a solução de conflitos e (vi) competência para expedir recomendações de cunho orientativo (Pensando o Controle da Atividade Estatal. GUERRA, Sérgio (org.). Temas de Direito Regulatório. Rio de Janeiro: Freitas Bastos, 2004, p. 213-214). Embora a classificação seja mais ampla do que a apresentada crê-se poder reconduzir as espécies apresentadas aos três núcleos apresentados.
} 
de competências normativas e atuação na resolução de conflitos causem maiores discussões, regulação depende, fundamentalmente, do exercício de atividades tradicionais que cuidam da aplicação concreta das pautas normativamente estabelecidas. Aliás, o grosso da regulação caracterizar-se-á pela prática de atos administrativos que não visam à composição de conflitos ou à criação de comandos gerais e abstratos. Aliás, pode-se dizer que essa função ordinária é a dotada de maior relevo no exercício concreto da regulação. A uma, a expedição de normas pressupõe a sua aplicação efetiva, ou seja, o exercício de competências normativas é ancilar à efetiva implementação delas. A duas, os litígios de que ordinariamente se ocupará o regulador dizem geralmente com a sua própria atuação no setor regulado.

Logo, malgrado haja menos ribalta em relação aos atos que impliquem na aplicação de normas a casos concretos (o que alcança a imposição de sanções e os atos de fiscalização) é evidente que essa atividade é inerente à eficácia da regulação.

Regulação, como bem lembra Egon Bockmann MOREIRA, não deixa de ser uma tarefa estatal que deve ser exercida em muitos casos com a autoridade inerente à garantia da efetiva implementação das finalidades públicas. ${ }^{249}$ Não se cuida de ordenar interesses privados disponíveis, e sim de fazer valer uma finalidade que, sem a presença da Administração, não seria implementada pelos particulares na busca de seus interesses. Assim, por mais que se invistam em esquemas consensuais sempre haverá um núcleo de autoridade inerente à regulação e sua tradução jurídica se dá por meio de atos que seguem o modelo consagrado de atuação administrativa.

Neste campo valem os pressupostos de autoridade consagrados no Direito Administrativo Brasileiro sendo, inequivocamente, a Administração aparelhada de meios eficientes de fazer prevalecer os interesses definidos como adequados em detrimento dos interesses particulares. Embora possa se apontar o recurso a técnicas consensuais como uma característica da regulação é de se destacar que isso não implica em retirar da Administração a capacidade de atuar autoritariamente quando a situação o exigir. Dificilmente poderia se conceber uma atuação administrativa que se fundasse apenas em esquemas consensuais.

Do exercício de competências administrativas ordinárias é que se faz o grosso da regulação. A fixação de comandos abstratos e genéricos e a solução de controvérsias não têm o condão de reduzir a importância que desempenha para a regulação à prática de atos que, de

\footnotetext{
${ }^{249}$ MOREIRA, Egon Bockmann. In Os Limites..., p. 180-181.
} 
ofício, aplicam normas aos casos concretos com vistas a alterar os padrões de comportamento dos particulares. Seria de todo incoerente destacar que a Administração hodiernamente tem a missão de estruturar o desenvolvimento sem lhe reconhecer a capacidade de adotar os atos que de modo mais elementar garantam isso.

Somando-se à atuação administrativa mais comum ressalta-se no exercício da regulação a assunção da Administração da posição de árbitra de interesses que entrem em conflitos (dela com os particulares ou mesmo apenas entre privados). ${ }^{250}$ Uma vez destacada a nota de tensão ínsita à regulação, é de se ver que a adoção de determinadas medidas pode gerar conflitos de monta entre os diversos interessados.

Embora o sistema brasileiro consagre a unidade de jurisdição, submetendo a atuação administrativa a ampla margem de revisão judicial, é de se ver que em setores regulados a assunção da Administração da posição de mediadora de conflitos é de extrema importância. Quando menos, a atuação da Administração compondo conflitos visa a garantir um primado de unidade no que diz respeito à interpretação das políticas setoriais aplicadas, zelando pela sua aplicação congruente. Assim, importa encarecer que essa faceta da função regulatória é importante como garantia da própria regulação. Como adverte Marçal JUSTEN FILHO: “Ao examinar o caso concreto e, em alguns casos, compor conflitos entre particulares, o Estadoregulador atua não no interesse das partes. Realiza uma função pública específica, a intervenção regulatória."251

Com efeito, julgar conflitos acerca do exercício da função regulatória também é exercer regulação. Desse modo, não raro, ao se atribuir competência regulatória para determinado estrutura administrativa lhes são garantidas competências para adjudicar conflitos no setor em que irá atuar.

Todavia, abordar o tema com propriedade deve se destacar que, diferentemente dos modelos tradicionalmente aplicados na Europa (de jurisdição dual), no sistema brasileiro a atuação decisória administrativa, de modo algum, apresenta-se como definitiva. $\mathrm{O}$ recurso ao Judiciário é sempre uma alternativa viável para o cidadão que se sentir lesado por qualquer sorte de ato administrativo, inclusive os que dão solução a conflitos. Não pode a adoção de qualquer política regulatória pretender subtrair do Judiciário qualquer sorte de conflito. No

\footnotetext{
${ }^{250}$ A ANEEL detém expressamente tal competência (art. $3^{\circ}$, V, da Lei n ${ }^{\circ}$ 9.426/96) e a ANATEL também (art. 19, XVII da Lei $n^{\circ}$ 9472/97).

${ }^{251}$ JUSTEN FILHO, Marçal. O Direito..., p. 556.
} 
sistema brasileiro a Administração pode ser demandada em juízo sem qualquer restrição sendo inconstitucional qualquer medida que vise a amesquinhar a intangibilidade do acesso à Justiça $\left(\mathrm{CF}\right.$, art. $\left.5^{\circ}, \mathrm{XXXV}\right)$. Assim, tudo o que se diga acerca do tema deve ter por norte a ampla sindicabilidade das decisões administrativas, mesmo as tomadas no exercício da regulação. ${ }^{252}$

Nesse sentido, a utilidade das competências decisórias dos entes que exercem a regulação depende da sua capacidade de dar respostas adequadas aos conflitos que se apresentam, granjeando legitimidade suficiente para não ter seus atos usualmente postos em causa junto ao Poder Judiciário. Assim, o grau de desvelo com que a Administração enfrentar os temas complexos afeitos à regulação, dotando os interessados de respostas satisfatórias aos seus pleitos é fonte de legitimação da atuação regulatória por meio de decisões. Como anota Marçal JUSTEN FILHO: (...) a submissão do litígio à decisão da agência também se justifica pela constatação das dificuldades que entranham o desenvolvimento da atividade jurisdicional. Um processo judicial demandará anos para encerrar-se, com decisões que - em muitos casos revelarão ausência de condições do magistrado apreender mesmo a natureza essencial da controvérsia."

Importa destacar que na atividade de julgar conflitos, a Administração Pública deve atuar inexoravelmente segundo as pautas do devido processo legal, seja em face de litígios dela com privados, seja nos casos em que está analisando questões em que não é parte interessada. Há plena incidência das cláusulas constitucionais que garantem do devido processo legal $\left(\mathrm{CF} / 88\right.$, art. $5^{\circ}$, LIV e LV).

Por fim, é de se destacar a questão das competências normativas usualmente associadas à regulação. O tema, dentre os ora analisados, é sem dúvida o que maior questionamentos suscita. Isto, pois, a atribuição de competências normativas para a Administração não é usual e traz, inexoravelmente, questionamentos de tal prática em face do princípio da legalidade e da separação de poderes.

Haja vista a maior complexidade do tema, ele será tratado sem tópico próprio, de modo autônomo.

\footnotetext{
252 Nesse sentido manifesta-se Marçal JUSTEN FILHO acerca das capacidades decisórias das agências reguladoras destacando a necessidade de se ter em mente que o produto da atuação das agencias não está infenso à revisão judicial (Ibidem, p. 555).
} 


\subsubsection{Regulação e Função Normativa}

Tema dos mais disputados acerca da função regulatória é a possibilidade de se estabelecerem quadros normativos pela Administração Pública de modo a se impor a transformação das condutas naturais dos mercados. Neste ponto há nítida separação da doutrina, havendo autores que rejeitam essa possibilidade, autores que a aceitam sem maiores reservas e dentre estes extremos algumas posições mais comedidas.

A contextualização do problema remete de imediato à evidência de que, desde a emergência do Estado Social, a função reservada a Administração, e ao Executivo, só fez aumentar, ampliando-se à custa da perda de importância reconhecida às leis (e quem as formula). $\mathrm{O}$ exercício de funções normativas pelo Executivo é a última fronteira desse intenso debate que toca mesmo à caracterização do Estado dos dias atuais. Em última instância, o que está em causa é como o Estado dos dias atuais deve atuar de modo a cumprir os seus compromissos e em que limites é possível que a Administração se valha da expedição de comandos normativos. A discussão acerca do exercício de função normativa pela Administração toca de imediato em dois elementos essenciais à dogmática do Direito Administrativo, a separação dos poderes e a compreensão do princípio da legalidade. Não por outra razão o tema é objeto de tão intenso debate.

Desde o prisma constitucional, a questão ainda suscita maiores debates, haja vista a conformação peculiar da Constituição de 1988, que é extremamente analítica, especialmente, em relação ao exercício das prerrogativas por parte das diversas autoridades públicas e os limites das competências a elas reservadas.

Antes de ferir o tema, é de se fazer uma ressalva metodológica prévia. Não raro os autores tratam da matéria com olhos diretamente nas leis que cuidam de atribuir a entes administrativos competências regulamentares. Contudo, a discussão nesse sentido só será válida uma vez demonstrado que a constituição aceita esse proceder. Cuidar do tema apenas em atenção aos conteúdos de lei é impróprio e, não raro, conduz a conclusões que incidem a flagrante petição de princípio. Parte-se da lei (admitindo uma premissa implícita de constitucionalidade do seu conteúdo) para dizer que elas franqueiam competências normativas, para assim concluir que a Constituição autoriza esse proceder. Construir raciocínios desta ordem é manifestamente improcedente. O tema deve ser ferido de modo 
exaustivo primeiramente na Constituição para se formar a premissa de que o sistema permite (se é que o faz) o exercício de competências normativas, posteriormente, há de se ver a extensão dessa possibilidade. A análise da lei é apenas residual. É o método que se pretende utilizar.

Verificando as posições possíveis sobre o tema, importa assinalar a absoluta divisão da doutrina acerca do tema. De um lado, a maior parte dos autores, rejeitando a atribuição de poderes normativos à Administração e, de outro, uma parcela minoritária que a admite, sobre diversos fundamentos. Importa analisar ambas as posições com maior atenção, em especial examinando os argumentos constitucionais invocados.

A doutrina majoritária, como mencionado, rejeita qualquer autonomia da Administração em relação ao exercício de competências normativas salvo nos casos em que expressamente a Constituição o permite de modo explícito. Os argumentos dessa linha vão fortes no sentido de qualquer margem de autonomia normativa à Administração contrariar o princípio constitucional da separação de poderes, a vinculação do poder regulamentar à especificação das leis (para sua fiel execução), bem como a legalidade estrita a que se submete o exercício de qualquer função administrativa. Para estes doutrinadores a Administração, salvo a hipótese do poder regulamentar para expedir comandos para a fiel execução da lei, não poderia se valer de qualquer possibilidade de valer-se de atribuições normativas.

É da tradição do direito brasileiro negar a possibilidade de o Executivo deter qualquer autonomia normativa, mesmo à luz de textos normativos anteriores. Apenas para registro, sem prejuízo de diversas opiniões similares acerca do assunto, anotou com precisão Francisco CAMPOS sobre a matéria, dando a tônica do entendimento sobre a matéria:

(...) e o poder administrativo, não só com a função idêntica de subsumir as situações individuais sob o preceito legal, mediante o ato administrativo, como com a função mais ampla de editar, mediante o regulamento, regras secundárias destinadas a dar às leis uma execução satisfatória. No exercício, porém, do poder regulamentar, por mais longe que possa ir o Poder Administrativo na formulação de regras ou de preceitos jurídicos, êle não exerce, entretanto, nesse domínio uma atividade livre. A lei condiciona estritamente a produção administrativa de preceitos ou de regras de caráter jurídico, limitada a sua atividade, no que toca as medidas regulamentares destinadas à execução da lei, tão-sòmente editar aquêles preceitos ou aquelas regras jurídicas que tenham por fim tornar executórios os preceitos e as regras legais, mediante dispositivos que, por serem de caráter meramente administrativo, o legislador deixou e podia deixar à prudente discrição do administrador. No exercício do poder regulamentar, a administração não pode, portanto, sob o pretexto de lacunas na lei a ser executada, dispor em relação ao seu objeto com a mesma amplitude e a mesma liberdade com que em relação a êle poderia dispor o 
Poder Legislativo, ainda que se limite à criação de meios e instrumentos destinados à realização de uma finalidade, que a lei se cinge a formular em termos vagos e gerais. ${ }^{253}$

Essa linha de argumentação ainda é encontrada na doutrina brasileira, rejeitando-se a possibilidade de atribuições normativas à Administração se estas forem além da mera expedição de comandos para "fiel execução" do diploma legal. Em última instância o que se recusa é a possibilidade de a Administração criar obrigações, direitos e deveres que já não estejam previamente determinadas em lei de modo exaustivo, não havendo qualquer margem nesse sentido para o administrador. Nesta linha é que se diz que a Administração não pode inovar originariamente a ordem jurídica, limitando-se a expedição de comandos subordinados à lei.

O fundamento constitucional mais relevante invocado para dar suporte a tais conclusões é o princípio da legalidade. Como preleciona o art. $5^{\circ}$, II, da Constituição que "ninguém será obrigado a fazer ou deixar de fazer alguma coisa senão em virtude de lei" nada restaria à Administração que não implementar regras instrumentais à aplicação das leis. Nunca, todavia, poderia se admitir que algo viesse vertido originalmente via regulamento. ${ }^{254}$

Nesta linha, o comando contido no art. 84, IV (que autoriza a expedição de decretos para a fiel execução da lei, exclusivamente, pelo chefe do Executivo) seria mero reflexo dessa concepção de legalidade que obriga que todas as estatuições que visam a sujeitar os cidadãos devam estar vertidas em lei. Assim, deve se compreender o poder regulamentar com olhos no princípio da legalidade, não prosperando qualquer autonomia normativa por parte da Administração. Ainda, no que diz com a competência dos Ministros de Estado, o art. 87, parágrafo único, II, novamente, alude à execução das leis, o que leva a não se reconhecer a possibilidade de exercício de competência regulamentar que não seja pautada por tais balizas.

Concorrendo com estes argumentos tem-se que o art. $37 \mathrm{da} \mathrm{CF} / 88$ quando fixa os princípios reitores da atividade administrativa, traz a legalidade como norma a ser observada. Assim, por mais esta razão não seriam admitidos regulamentos que possuíssem qualquer margem que não estivesse contida nas balizas da fiel execução.

\footnotetext{
${ }^{253}$ CAMPOS, Francisco. Lei e Regulamento - Matéria Reservada à Competência do Poder Legislativo - Limites do Poder Regulamentar - Direitos e Garantias Individuais. Revista Forense, Rio de Janeiro, n. 146, 1955, p. 71.

${ }^{254}$ Por todos, acerca do tema, consulte-se a opinião de Celso Antônio Bandeira de MELLO: “(...) os dispositivos caracterizadores do princípio da legalidade no Brasil impõem ao regulamento o caráter que se lhe assinalou, qual seja, o de ato estritamente subordinado isto é, meramente subalterno e, ademais, dependente de lei." (In Curso..., p. 317.)
} 
Ainda, há diversas outras passagens em que a Constituição houve por bem reiterar a necessidade de haver lei para determinadas atuações do Poder Público em face dos cidadãos, reforçando o espírito da Constituição com a estrita legalidade. São os casos referentes à imposição de penas (art. $5^{\circ}$, XXXIV), à imposição de tributos (art. 150, I) e à liberdade de exercício de atividade econômica (art. 170, parágrafo único). ${ }^{255}$

Outro argumento invocado, ainda que de maneira menos usual, é que o Ato das Disposições Constitucionais Transitórias teria cassado todas as delegações de matérias reservadas ao Congresso para a Administração. ${ }^{256}$ Assim, no regime de transição constitucional, estaria claro que não cabem delegações de poder normativo, ainda que vertidas em lei, salvo nas hipóteses de expressas prorrogações de normas anteriores à vigência constitucional. Ou seja, a prescrição do ADCT, verteria um princípio geral que proscreveria a delegação de atribuições de lei, à Administração.

O pano de fundo de tais concepções está na própria compreensão acerca do princípio da separação de poderes que vedaria o exercício pela Administração de qualquer função normativa dotada de foros de autonomia, suplantando o âmbito de estrita vinculação à execução da lei. Sob essa ótica não poderia haver qualquer delegação (utilizado o termo de modo amplo), muito especialmente de atribuição normativa ao Executivo, mesmo que isto fosse levado a efeito por lei. Sobre o tema, anota de modo expresso Celso Antônio Bandeira de MELLO: "Com efeito, a indelegabilidade, enquanto princípio constitucional, resulta diretamente, ainda que de modo implícito, do art. $2^{\circ}$ do Texto Magno, de acordo com o qual: 'São Poderes da União, independentes e harmônicos entre si, o Legislativo, o Executivo e o Judiciário'."257 Com efeito, a lei não poderia acometer a estruturas Administrativas a capacidade de regular matérias a si reservadas por estar-se contornando o espírito da

\footnotetext{
${ }^{255}$ Celso Antônio Bandeira de MELlo sintetiza nestes termos: "Ressalte-se que, dispondo o art. 5o, II, da Constituição que 'ninguém será obrigado a fazer ou deixar de fazer alguma coisa senão em virtude de lei', com isto firmou o princípio da garantia da liberdade como regra, segundo a qual 'o que não está proibido aos particulares está, ipso facto, permitido'. Ante os termos do preceptivo, entende-se: 'o que não está por lei proibido, está juridicamente permitido'. De outro lado, conjugando-se o disposto no artigo citado com o estabelecido no art. 84, IV, que só prevê regulamentos para 'fiel execução das leis', e com o próprio artigo 37, que submete a Administração ao princípio da legalidade, resulta que vige, na esfera do Direito Público, um cânone basilar - oposto ao da autonomia da vontade -, segundo o qual: o que, por lei, não está antecipadamente permitido à Administração está, ipso facto, proibido, de tal sorte que a Administração, para agir, depende integralmente de uma anterior previsão legal que lhe faculte ou imponha o dever de atuar. Por isso deixou-se dito que o regulamento, além de inferior, subordinado, é ato dependente de lei." (Ibidem, p. 320-321.)

${ }^{256}$ Esse argumento é invocado expressamente por Maria Sylvia DI PIETRO ao analisar o tema (in Limites..., p. 52).

${ }^{257}$ MELLO, Celso Antonio Bandeira de. In Curso..., p. 331.
} 
Constituição. Assim, a estatuição originária de comandos restaria reservada em absoluto para a lei, que não poderia transigir acerca do tema. ${ }^{258}$

Eis o Estado da arte em relação aos autores que negam à possibilidade de se admitir qualquer margem de autonomia da Administração em relação à edição de regulamentos, vinculando tais atos normativos à fiel execução da lei; nada além, nada aquém. ${ }^{259}$

Opondo-se a esta linha, há autores que admitem (em maior ou menor grau) a possibilidade de a Administração exercer competências normativas para além da mera execução de comandos legais. Dentre os que expressamente assim o fazem estão, exemplificativamente: Caio TÁCITO, ${ }^{260}$ Eros Roberto GRAU, ${ }^{261}$ Tércio Sampaio FERRAZ JÚNIOr, ${ }^{262}$ Floriano Peixoto de Azevedo MARQUES NETO, ${ }^{263}$ Diogo de Figueiredo MOREIRA NETO, ${ }^{264}$ Sérgio Varella BRUNA, ${ }^{265}$ Carlos Roberto Siqueira CASTRO, ${ }^{266}$ Alexandre dos Santos ARAGÃO ${ }^{267}$, Marcos Juruena Villela SOUTO, ${ }^{268}$ Leila CUÉLLAR, ${ }^{269}$ Egon Bockmann MOREIRA, ${ }^{270}$ dentre outros.

Em relação à doutrina dos autores acima citados, não há perfeita coincidência em todos os argumentos invocados, contudo, em linhas gerais, podem ser arrolados alguns preceitos

\footnotetext{
${ }^{258}$ É o que Celso Antônio Bandeira de MELLO chama de "delegações disfarçadas", de modo a rejeitar de modo explícito que a lei crie competências normativas próprias para a Administração, o que ocorreria em se admitindo a possibilidade de "deslegalização" ou a existência em nosso sistema de "regulamentos autorizados" (Ibidem, p. 328-334).

${ }^{259}$ Como já assinalado, a maior parte da doutrina adota entendimento símile ao ora exposto, ainda que com alguns temperamentos. Todavia, a posição amplamente majoritária vai no sentido de negar, para além do limite de fiel execução da lei. Por esta razão deixa de se indicar pormenorizadamente autores que vão nessa linha. Mais útil é indicar as exceções às regras gerais, como se fará adiante.

${ }^{260}$ TÁCITO, Caio. In As delegações Normativas e o Poder Regulamentar, in Temas de Direito Público (Estudos e Pareceres), Rio de Janeiro: Renovar, 1997, p. 507-510, dentre outros textos que tangenciam o tema.

${ }^{261}$ GRAU, Eros Roberto. In O Direito..., p. 225-255.

${ }^{262}$ FERRAZ JÚNIOR, Tércio Sampaio. In Agências..., p. 143-158. A opinião do autor acerca do tema foi reafirmada em estudo posterior mais completo chamado O Poder Normativo das Agências Reguladoras à luz do Princípio da Eficiência, in O Poder Normativo das Agências Reguladoras, coord. Alexandre Santos ARAGÃO, Rio de Janeiro: Forense, 2006, p. 271-297.

${ }^{263}$ MARQUES NETO, Floriano Peixoto de Azevedo. In Regulação..., p. 205.

${ }^{264}$ MOREIRA NETO, Diogo de Figueiredo. In Direito..., p. 113-128.

265 BRUNA, Sérgio Varella. In Agências Reguladoras, Poder Normativo, Consulta Pública, Revisão Judicial, São Paulo: RT, 2003, p. 68-141.

266 CASTRO, Carlos Roberto Siqueira. In Devido Processo Legal e os Princípios da Razoabilidade e da Proporcionalidade, 3. ed. Rio de Janeiro: Forense, 2005, p. 67-139.

${ }^{267}$ ARAGÂO, Alexandre dos Santos. In Agências..., p. 369-430.

${ }^{268}$ SOUTO, Marcos Juruena Villela. In Direito Administrativo Regulatório. Rio de Janeiro: Lumen Juris, 2002. p. 24-28.

${ }^{269}$ CUÉLLAR, Leila. In As Agências Reguladoras e seu Poder Normativo. São Paulo: Dialética, 2001, p. $107 ; 142$.

${ }^{270}$ MOREIRA, Egon Bockmann. Agências Administrativas, Poder Regulamentar e o Sistema Financeiro Nacional. Estudos de Direito Econômico, Belo Horizonte; Fórum, 2004, p. 133-160.
} 
constitucionais comumente invocados a fim de justificar o exercício mais amplo de competência legislativa por parte da Administração: (i) que a separação de poderes não pode ser lida como dogma absoluto de modo a restarem proscritas as possibilidades de um determinado poder exercer funções que não lhes são típicas - mais ainda - a função administrativa não exclui o exercício de competência normativa, que lhe seria própria em certos casos; ${ }^{271}$ (ii) que a existência de matérias expressamente reservadas à integral disciplina em lei, conduz à inexorável conclusão de que para além destas hipóteses expressas, há possibilidade de normatização por parte da Administração, via regulamento; ${ }^{272}$ (iii) a dicção contida no art. $5^{\circ}$, II alude a "em virtude de lei", disto se inferindo que não há necessidade de que a lei regre a matéria de modo minudente podendo o legislativo reservar à Administração a disciplina de certas matérias (que teria ainda força vinculante "em virtude da lei"), é o que usualmente se chama de "deslegalização", isto é, o rebaixamento pela lei do grau hierárquico necessário para se tratar de um certo tema; ${ }^{273}$ (iv) que a Constituição ao aludir, no seu 48 , caput, à possibilidade de o Legislativo "dispor sobre todas as matérias", franquearia a possibilidade de se efetivar a deslegalização, nesse sentido os legisladores "disporiam” (no

\footnotetext{
${ }^{271}$ Incisivo nesse ponto é Eros Roberto GRAU, que atribui à função administrativa a capacidade de regrar situações conjunturais. Diz o referido autor que, desde o ponto de vista material, a função normativa não seria exclusiva do Legislativo, e que não se deve analisar a separação de poderes apenas sob o prisma subjetivo. A essência desta garantia seria a capacidade de criar-se um equilíbrio entre as diferentes estruturas do Estado, sem que isso representasse uma divisão absolutamente estanque. A Administração tem o dever de atuar de modo a desincumbir-se de suas missões institucionais, não lhe podendo ser suprimida certa capacidade de atuação normativa, necessária a este fim. Adota então o autor entendimento no sentido de serem constitucionais "regulamentos autorizados", em que a lei atribuiria à Administração competência para integrar comandos genéricos por ela vertidos, mesmo que isto implique em criar direitos, deveres e obrigações que não estão totalmente regulados legislativamente. Outro ponto invocado diz com o fato de ser irretorquível que no Brasil de fato a Administração vem exercendo atribuições normativas, sendo necessário encetar uma teoria jurídica apta a explicar estes fenômenos (ao revês da sua simples negativa, que não corresponde à nossa realidade institucional). In $O$ Direito..., p. 225-255.

${ }^{272}$ Novamente, o argumento é defendido por Eros Roberto GRAU (o que parece, aliás, ser a observação mais inovadora no seu pensamento). Diz ele acerca do tema: "se há um princípio de reserva da lei - ou seja, se há matérias que só podem ser tratadas pela lei -, evidente que as excluídas podem ser tratadas em regulamentos; quanto à definição do que está incluído nas matérias de reserva de lei, há de ser colhida no texto constitucional; quanto a tais matérias não cabem regulamentos. Inconcebível a admissão de que o texto constitucional contivesse disposição despicienda" (Ibidem, p 247).

273 A deslegalização, usualmente, é invocada como dando suporte à atuação normativa da Administração, consistindo na degradação do grau normativo. Por meio dela, a lei disporia da matéria, atribuindo-a à disciplina pela Administração, ressalvados algumas balizas necessárias e suficientes para o controle da atividade normativa infra-legal, pelo Legislativo e pelo Judiciário. Vários são os autores que utilizam essa sorte de argumento para justificar as competências normativas atribuídas por leis a entes da Administração, dentre eles: Diogo de Figueiredo MOREIRA NETO, Alexandre dos Santos ARAGÃO e Marcos Juruena Villela SOUTO. Autores que adotam a possibilidade do "regulamento autorizado", como Eros Roberto Grau e Sérgio Varella BRUNA, em última instância parecem acatar a tese na medida em que a lei trespassaria, neste caso, competência para a Administração normatizar uma matéria.
} 
sentido de trespassar) de matérias definidas para o Executivo ${ }^{274}$ (v) que a existência a possibilidade do Legislativo "sustar os atos normativos do Poder Executivo que exorbitem do poder regulamentar" (cf. CF/88, art. 48, V) implica no reconhecimento de haver uma capacidade normativa a ser exercida, se reconhecer-se que apenas cabe expedir comando estritamente condicionados à lei a prescrição restaria sem sentido (por não se conceber a possibilidade de haver exorbitância); (vi) que o princípio da eficiência, ao disciplinar a atividade pelos resultados, implicaria na possibilidade de haver exercício de competências normativas, especialmente em matérias técnicas, que possibilitassem que a Administração satisfizesse esse múnus ${ }^{275}$ e (vii) que a atual conformação da sociedade reclama a adoção de um entendimento capaz de dotar a Administração de meios eficientes para desempenhar suas tarefas, repercutindo essas alterações na interpretação da Constituição. ${ }^{276}$

Eis a síntese dos mais relevantes argumentos jurídico-constitucionais invocados pela doutrina que tem uma concepção mais ampla da possibilidade de a Administração desempenhar funções normativas (i.e. para além dos limites da fiel execução). Além destes, há uma série de argumentos de índole conjunturais que, por não deterem conteúdo jurídico (em especial, relevo constitucional), deixam de ser analisados de modo explícito. Com efeito, o tema em tela é antes de tudo Constitucional, sendo que as respostas a ele devem ser hauridas do Texto Constitucional.

Vistas as posições possíveis em relação ao tema, importa pô-las em cotejo, de modo a analisar o tema por um viés crítico, isento de posições radicais. De um lado, há de se evitar a tendência de atribuir aos novos foros de absoluta excelência, pelo simples fato de se opor ao antigo; de outro, há de se afastar a postura inversa, que nega qualquer possibilidade de evolução do direito, não reconhecendo que a matéria jurídica é filha de um tempo e que o direito é um instrumento não se esgotando em si mesmo. ${ }^{277}$

\footnotetext{
${ }^{274}$ Adotando essa justificativa tem-se a lição de Diogo de Figueiredo MOREIRA NETO: “a deslegalização foi também um instrumento contemplado pelo constituinte brasileiro de 1988, desde logo quando, no emprego do poder de dispor, no sentido de 'resolver em caráter definitivo', transfere a entes ou órgãos públicos, bem como a entes particulares, a função de disciplinar por normas certos setores.” (O Direito..., p. 123.)

${ }^{275}$ Esse argumento é, especialmente, encarecido por Tércio Sampaio FERRAZ JÚNIOR (O Poder..., p. 151). Importa assinalar que a questão do "poder normativo", em função da necessidade de a Administração emitir juízos técnicos é recorrentemente tratada por grande parte da doutrina que admite a sua existência.

${ }^{276}$ Dentre outros, Tércio Sampaio FERRAZ JÚNIOR tangencia essa idéia e Carlos Roberto Siqueira CASTRO a defende de modo expresso.

${ }^{277}$ É de se destacar também que o tema não é novidade em nosso direito. Caio TÁCITO, após identificar que a tradição de nosso direito público, desde a Constituição de 1824, é de atribuir poder regulamentar ao chefe do Executivo para a "boa execução das leis", anota diversas posições contrárias a uma leitura estrita desta regra.
} 
O tema como visto, suscita vastas dúvidas, em especial por tocar à dinâmica mais intestina referente ao exercício do poder no seio da República. É, em última análise, do arranjo interno de poderes entre as diferentes estruturas que o exercem que está a se cogitar; daí o tema render ensejo a posições extremadas, quer a favor, quer contra, o exercício da função normativa por parte da Administração.

Como ponto de partida para uma análise das duas posições, analisando os diferentes argumentos invocados em ambos os sentidos, interessante é evidenciar que, desde antes da criação das Agências Reguladoras (e, pois, do seu "poder normativo”) há no Brasil entes que desempenham funções que vão além da expedição de meros atos normativos a bem da fiel execução da lei. Aliás, este fenômeno é típico em campos em que a especificidade técnica se faz presente. Como antecessores do exercício destas funções, apenas exemplificativamente, cite-se as Autarquias e Órgãos que atuam no sistema financeiro. O Conselho Monetário Nacional, o Banco Central, a Comissão de Valores Mobiliário vêm, desde antes da Constituição de 1988, exercendo atribuição de especificação normativa de comandos legais genéricos e isto por certo vai além do âmbito restrito de especificar a lei para sua fiel execução. $^{278}$

Assim, em um certo sentido, é claro na experiência jurídica brasileira, que malgrado as acaloradas discussões que o tema suscita, o Legislativo, de fato, articula-se com a Administração de modo a que esta venha a integrar dispositivos emanados por aqueles de modo genérico, havendo expressas autorizações legais que criam tais competências. Ou seja, a experiência prática do direito pátrio conhece a existência de atos normativos emanados pela Administração que integram comandos legislativos prévios dotando-os de um sentido concreto, dando a eles especificidade, especialmente, em matérias técnicas.

Desde a emergência do Estado Social, tem sido essa a tônica, exigindo-se uma maior participação da Administração na definição última das normas que estão a veicular comandos aos cidadãos. Em um panorama em que a Administração recorrentemente é chamada a atuar, natural que se lhe seja acrescida a função de emanar comandos genéricos e abstratos (que vão além do mero acertamento de um caso individual pela subsunção de uma conduta à regra

Cita, inclusive, opinião de Rui Barbosa, datada de 1912, no sentido de não ser viável uma separação absoluta de poderes e a inviabilidade de conceber os regulamentos apenas para executar as leis (In Comissão de Valores Mobiliários. Poder Regulamentar, Temas de Direito Público (estudos e pareceres). v. 2. Rio de Janeiro: Renovar, 1997, p. 1078-1079).

${ }^{278}$ Especificamente sobre o tema consulte-se Egon Bockmann MOREIRA (In Agências ..., p. 133-160). 
legislativa). Este é o pano de fundo que lega a discussão acerca da capacidade normativa do Poder Executivo. O ideal de pureza das funções, e a esperança de que as leis poderiam atuar no plano abstrato (e a Administração seria responsável apenas por atuá-las), mostrou-se muito mais um esquema teórico do que uma realidade efetiva. ${ }^{279}$ A emergência de um paradigma intervencionista desnudou a impossibilidade de implementação concreto deste modelo sendo que as generalidades dos sistemas jurídicos ocidentais conhecem esquemas de articulação entre a função normativa e a função executiva. Aliás, a contra-face desse movimento de interpenetração entre o que incumbe à Administração e o que compete ao Legislativo fica evidente quando se tem em mira as chamadas leis medida (ou de efeitos concretos), cuja matéria é de verdadeiro ato administrativo. ${ }^{280} \mathrm{O}$ escorço evolutivo levado a efeito anteriormente tem o ensejo de demonstrar que nos dias atuais já não é clara a distinção entre matéria de lei e matéria administrativa e que, mais e mais, surgem novas formas de arranjo entre Legislativo e Executivo.

Como anota Fábio Konder COMPARATO, há o surgimento da necessidade de o Estado (categoria que sublima Legislativo, Executivo e Judiciário) atuar de modo a dar satisfação aos compromissos postos pela ordem jurídica, o que rebela uma noção estanque das funções estatais. Diz o jurista acerca do tema:

\begin{abstract}
Nesse sentido, já não cabe tratar a regulação estatal das atividades econômicas como mera intervenção excepcional e temporária - do Estado no campo econômico privado, mas como o desempenho ordinário de um dever constitucional. É óbvio, porém, que a legitimidade dessa ação estatal reguladora da vida econômica privada dependerá sempre do criterioso respeito aos objetivos e princípios fixados na Constituição (...) No cumprimento dessas diretrizes constitucionais, o legislador e o administrador são obrigados a agir, na área específica de sua competência, editando normas gerais, expedindo decretos e
\end{abstract}

\footnotetext{
${ }^{279}$ Noticiam Eduardo García de ENTERRÍA e Tomás-Ramón FERNÁNDEZ que desde 1789 na França houve, sob os rótulos de "proclamations" e "arretés" a expedição de normas em sentido estrito pelo Executivo, o que demonstra a relatividade do tema (Op. cit., p. 183).

${ }^{280} \mathrm{Em}$ relação às leis de efeito concreto é de se assinalar que a doutrina brasileira ainda não analisou o tema de modo minudente. Aliás, é de se anotar que a prática de atos legislativos dotados de conteúdo concreto pode vir a ser extremamente perniciosa. Por exemplo, a lei concreta que verte uma declaração com vistas à expropriação de um bem parece padecer de vício constitucional bastante grave. Ora, se a declaração é vertida pela Administração o administrado pode insurgir-se contra isto em processo administrativo sustentando, por exemplo, que houve desvio de poder, tudo isto informado pelos princípios da ampla defesa e do contraditório. Em sendo a declaração vertida por lei, ao administrado não cabe nenhuma capacidade de concorrer previamente para a prática do ato o que parece ofensivo ao devido processo legal. Veja-se que, em ambos os casos (ato administrativo ou lei de efeitos concretos), caberia a impugnação via mandado de segurança, todavia, na declaração especificamente levada a efeito por lei, antes da prática do ato, nada poderia fazer o administrado. Isto demonstra a possibilidade de atos concretos emanados do Parlamento serem extremamente lesivos aos administrados, embora isso passe ao largo de tais discussões por ser o ato emanado do Legislativo. A problemática conecta-se manifestamente à separação de poderes.
} 
provimentos administrativos, fiscalizando o cumprimento das normas editas e sancionando as transgressões. 281

Com efeito, a lição maior que se infere da passagem transcrita é que o Estado atual está jungido a um dever de atuação e dele deve se desincumbir a contento, o que justifica a atribuição de poderes instrumentais à Administração para tanto, inclusive, de ordem normativa.

Cuida-se do que Eros Roberto GRAU vai chamar de "capacidade normativa de conjuntura" $^{282}$, bem como é o que motiva a crítica de Karl LOWENSTEIN acerca da inadequação da visão usual acerca da separação dos poderes para explicar o exercício de poderes após o Estado Social. É esse dever de atuação do Estado que sobre um certo sentido põe em causa uma visão estanque acerca da separação dos poderes.

Nesta linha, é necessário buscar quais as possibilidades de articulação entre lei e atividade normativa do Poder Executivo em vista de um Estado comprometido com a promoção do bem estar, como o determinado pela Constituição. Veja-se, desde logo, que se configura absolutamente inviável defender a possibilidade de haver uma regulação exclusiva em lei de todos os quadrantes da vida social, sendo de fato a Administração um mero ente de atuação dos comandos emanados do Legislativo, sem qualquer missão outra que não essa. Obviamente, à Administração reserva-se papel mais amplo do que mera aplicação mecânica de leis, exige-se um compromisso de transformação da realidade. Aliás, no limite, uma concepção absolutamente cerrada da legalidade e da separação dos poderes vedaria a técnica da discricionariedade que se admite sem quaisquer reservas como um modo de a Administração vir a instituir soluções ótimas para casos em que não é possível tarifar desde logo qual seria a melhor aplicação do interesse público para um caso concreto.

Com base nesta premissa é que devem ser analisadas as regras constitucionais que cuidam do tema, com serenidade e evitando excessos.

Um ponto importante dos que defendem uma capacidade normativa para além da mera regulamentação estrita para fins de fiel execução da lei parece ser a evidência de que na Constituição, de fato, se põem dois planos em relação à legalidade. A existência de matérias reservadas à estrita e integral disciplina por lei faz crer que em relação às outras matérias o

\footnotetext{
${ }^{281}$ COMPARATO, Fábio Konder. In Regime Constitucional..., p. 101;103.

${ }^{282}$ GRAU, Eros Roberto. In O Direito..., p. 232.
} 
princípio da legalidade opera-se em outro plano. Vale dizer haveria duas legalidades instituídas pela Constituição. Pensar de modo diverso, como assevera Eros Roberto GRAU, é supor que a Constituição tenha se valido de disposição vazia de sentido, repetindo-se de modo estéril.

Entre interpretar que a estatuição da legalidade estrita em certas matérias seriam meras redundâncias da Constituição ou atribuir sentido normativo pleno à distinção, parece ser esta última interpretação dotada de maior juridicidade.

Nesta linha, o vocábulo "em virtude de lei" restaria satisfeito nos casos em que a lei estatuísse comandos que configurassem regras de competência a serem desenvolvidas pela Administração. Nestes casos, isto é, não reservados de modo taxativo à integral disciplina por lei estar-se-ia diante do que Eros GRAU chamou de "reserva de norma", ${ }^{283}$ que poderia ser vertido tanto por atos oriundo do Legislativo, quanto da Administração. A exigência de disciplina exaustiva em lei se faria necessária apenas para aqueles casos em que a Constituição exigisse de modo expresso a disciplina por meio desta espécie (excluindo-se, aí, qualquer margem de atuação do Executivo). Nos demais casos a lei poderia outorgar competência à Administração para regular certas matérias dentro de certos limites.

À luz destas ponderações é que, segundo a doutrina que admite a existência de competências normativas para além da mera execução da lei, estaria autorizada a estatuição, por parte da Administração, de normas que podem implementar comandos não vertidos de modo exaustivo em lei.

Aprofundando essa linha, Sérgio Varella BRUNA acresce dois elementos importantes acerca do tema. O primeiro, que para estar satisfeito o requisito constitucional é necessário que haja a atribuição neste sentido de competência para a Administração, não se podendo supor títulos implícitos neste particular. ${ }^{284} \mathrm{O}$ segundo, é que em vista da separação das tarefas estatais, não difere substancialmente a atribuição de competência discricionária à Administração da atribuição de capacidade normativa autorizada por lei. Em ambos os casos

\footnotetext{
${ }^{283}$ Ibidem, p. 247.

${ }^{284}$ Neste sentido, assevera o autor citado: "Por outro lado, é preciso enfatizar, com veemência, que o comando geral, constante do art. $5^{\circ}$, II, da CF, de que não haja obrigação senão em virtude de lei, exige que efetivamente haja lei autorizando o exercício complementar de função normativa pelo Executivo." (in Agências..., p. 116). Neste ponto o magistério do autor afasta-se do que defende Eros Roberto GRAU para quem a exigência de o Executivo atuar bastaria como título autorizativo para a expedição de regulamentos dessa ordem, havendo uma competência normativa própria do Executivo, que exclui a possibilidade de se advogar que haja "delegação" de função legislativa nestes casos (In O Direito..., p. 249).
} 
têm-se a criação de uma competência específica a ser manejada pela Administração com vistas a integrar comandos legais; nas duas hipóteses a matéria não é exaurida pela lei que franqueia um espaço de avaliação a quem é atribuída a competência. Lei expressa atributiva de competência é condição de validade em ambos os casos, não diferindo, tomando por baliza a legalidade, a atribuição de discricionariedade e a autorização para a expedição de regulamento. ${ }^{285} \mathrm{~A}$ única diferença é que a técnica da discricionariedade se orientaria a decisão de soluções pontuais e a atribuição de competência normativa levaria a prática de comandos dotados de generalidade e abstração.

Em se adotando estas premissas (sob pena de em assim não se fazendo perpetrar-se estéril jogo de palavras), pode se compreender a disposição constitucional que franqueia ao Legislativo "dispor" sobre as matérias a si reservadas como significando acometer as competências de regular certos temas, dentro de certos limites, à Administração. Da mesma forma, ilumina-se o argumento de que a possibilidade de se cassarem atos normativos do Executivo que exorbitem da lei, implica no reconhecimento de uma competência própria nesse sentido. ${ }^{286}$

Todavia, tais argumentos de modo isolado não suportariam, que deles apenas, se extraíssem as conclusões ora postas. Apenas em uma interpretação sistemática, levando-se em consideração um quadro mais geral acerca do tema, eles ganham sentido, como argumentos de reforço. Embora por si não sejam capazes de levar à afirmação da possibilidade de a lei franquear à Administração competência para disciplinar certas matérias por ato normativo seu, tais argumentos, considerado o quadro geral visto, reforçam a possibilidade de se adotar um entendimento mais amplo acerca da competência regulamentar.

Outro argumento invocado, diz com o princípio da eficiência, lembrado por alguns doutrinadores como Tércio Sampaio FERRAZ JÚNIOR (“o princípio da eficiência traz para a discussão constitucional da delegação de competências um elemento novo."287). Nesta linha, ao se impor a legitimação da atuação administrativa por seus resultados (algo que parece

\footnotetext{
${ }^{285}$ Expressamente: "Como se vê, a mesma lógica que serve para vedar a 'delegação' não serve para vedar a 'discricionariedade', que nada é senão a atribuição de poder ao Executivo para agir como se fosse ele o legislador do caso concreto. Se não é dado ao Executivo 'criar' obrigações por intermédio de atos gerais, essa mesma competência lhe é reconhecida perante casos individuais.” (Ibidem, p. 99.)

${ }^{286}$ Sem embargo de opiniões divergentes, esse argumento isoladamente não suporta a conclusão da existência da existência de "poder regulamentar" que vá além da mera execução da lei. Pensar neste sentido é incorrer em petição de princípio, incluindo na premissa a conclusão que dela quer se extrair.

${ }^{287}$ FERRAZ JÚNIOR, Tércio Sampaio. In Agências..., p. 150.
} 
mesmo estar na essência da regulação, como visto), o que decorre da complexidade da vida social e econômica, deve se repensar a articulação lei/atividade administrativa. A criação de um ônus no sentido de uma atuação eficiente (fim) cria a necessidade de dotar a Administração de instrumento técnicos idôneos para atingi-los (meio), o que impõe supor uma maior capacidade de atuar a lei. Diz o autor, a propósito do tema: “(...) o princípio da eficiência exige que a Administração, em vista do mercado, seja dotada de competências reguladoras de natureza técnica e especializada sob pena de paralisia." ${ }^{288}$ Novamente, o argumento parece não sustentar, por si só, a existência de uma capacidade normativa autorizada por lei. Isto, pois, a eficiência autonomamente não tem o condão de alterar o esquema de exercício de atribuições entre os diferentes "Poderes" da República. Contudo, em um quadro mais amplo, a eficiência pode vir a assumir um papel de reforço no sentido de dotar a Administração de uma capacidade mais ampla de atuação com vistas a possibilitar que ela se haja bem com os encargos decorrentes deste princípio.

Voltando um pouco na linha expositiva, a chave parece estar na análise da estrutura do princípio da legalidade em relação aos condicionamentos impostos aos particulares. O ponto fundamental parece remeter, em última instância, a que tipo de disposição normativa reconhece-se como idônea para verter um comando cogente à coletividade. Embora seja usual a afirmação de que apenas lei pode inovar originariamente a ordem jurídica, é de se meditar no quê, exatamente, consiste inovar a ordem jurídica. Ou seja, a que tipo de disposição legislativa se reconhece idoneidade para a inovação da ordem jurídica. E esta análise está incondicionalmente informada pela concepção que se tenha acerca da legalidade.

Ora, se parte da premissa que o princípio da legalidade obriga que todo e qualquer dever esteja definido de modo absoluto em lei concluindo que a noção de inovação refletirá essa concepção. É dizer, todos os elementos necessários para a definição de uma conduta devem estar contidos na norma abstrata vertida pelo Legislativo, nada podendo estar alheio a ela. Outra será a concepção em se admitindo que é possível que se remeta, para além do texto legal, certos aspectos referentes à descrição conduta desejada.

A doutrina que nega a possibilidade de a lei remeter margens de apreciação para estatuição de comandos que a completam para a Administração parte da premissa implícita de que todos os elementos que descrevem a conduta estejam definidos em lei em sentido formal

\footnotetext{
${ }^{288}$ Ibidem, p. 151.
} 
(i.e como produto emanado do Parlamento). Todavia, reconhece que há necessidade de proceder certas articulações para que seja a lei operacionalizada de acordo com o seu sentido; é o que se percebe claramente com a seguinte transcrição do pensamento de Celso Antônio Bandeira de MELLO:

Há inovação proibida sempre que seja impossível afirmar-se que aquele específico direito, dever, obrigação, limitação ou restrição já estavam estatuídos e identificados na lei regulamentada (...) A identificação não necessita ser absoluta, mas deve ser suficiente para que se reconheçam as condições básicas de sua existência em vista de seus pressupostos, estabelecidos na lei e nas finalidades que ela protege.",289

Com o máximo acatamento ao pensamento do prestigiado professor, a transcrição põe a nu o problema fundamental em relação ao tema, qual seja, o que deve se entender por estatuição de um comando, originalmente, em lei. Frise-se, que o referido autor aceita, ainda que em grau indeterminado, a existência de uma articulação infralegal de modo a completar-se o sentido da norma, aludindo, entretanto, a que seu núcleo ("condições básicas") deva ser definido em lei.

Todavia, a identificação desse mínimo é problemática e sobre um certo sentido artificial.

Ora, descrição de uma conduta qualquer como juridicamente relevante pressupõe a análise de todos os elementos necessários para tanto; a sua integralidade é essencial para o processo de aplicação do direito. Se qualquer um deles estiver sido especificado por meio outro veículo que não a lei, em sendo coerente com o postulado da estrita legalidade como valor absoluto, é de se recusar aplicação à norma. Com efeito, a idéia de mera especificação da lei implica em que algo que não estava nela seja agregado. Assim, pretender que isso não concorra para a definição do conteúdo normativo é artificial. Todas as especificações, complementos, minudências têm sentido normativo e concorrem para a definição da imposição de uma conduta. Em última análise o que se tem por mero complemento é considerado para a aplicação das normas, integrando de modo indelével a aplicação do direito. A mera especificação é determinante se em determinado caso concreto um sujeito fará, ou não, jus a algo.

\footnotetext{
${ }^{289}$ MELLO, Celso Antônio Bandeira de. Curso..., p. 329.
} 
Essa não exaustão da disciplina em lei, não é negada pelos que se apegam à legalidade para refutar que a Administração exerça competências normativas definidas em lei. Demonstrando isto, tem-se o instituto da discricionariedade que cria uma margem de apreciação autônoma para o Administrador aplicar a norma a um determinado caso em vista de critérios de conveniência e oportunidade. Nesta hipótese, como já se disse, em se fazendo uma análise fria à luz da legalidade, a discricionariedade seria ofensiva a tal princípio na medida em que a lei não define de modo preciso uma conduta que sujeita a um determinado destinatário, quem o faz em última instância é a Administração. Aliás, tanto a discricionariedade não se coaduna com legalidade estrita, que as atividades do Estado em matéria penal e tributária reputam-se plenamente vinculadas, exatamente, para realçar que para os que curam de sua aplicação nenhuma margem de apreciação subjetiv é admitida

Nesta linha, a adoção da atribuição de regra de competência para a Administração emitir um juízo (normativo, no caso) acerca de determinadas matérias não parece ferir a concepção do sistema brasileiro acerca da legalidade (que, insista-se, reserva certas matérias a regramento integralmente legal).

Indo além, desde o Estado Social, há um quadro muitas vezes de dependência entre o administrado e a Administração, e as regras postas apenas e tão só para a fiel execução da lei guardam uma íntima conexão com a fruição do direito pelos cidadãos. A afirmação de Geraldo ATALIBA de que compete ao regulamento "dispor sobre medidas necessárias ao fiel cumprimento da vontade legal, dando providências que estabeleçam condições para tanto. Sua função é facilitar a execução da lei, especificá-la de modo praticável e, sobretudo, acomodar o aparelho administrativo, para bem observá-la." 290 , ainda que veladamente, compromete-se com uma concepção de que o modo pelo qual será executada uma lei é juridicamente indiferente, algo de somenos importância. Com efeito, o modo pelo qual a Administração especifica a lei e que estatui como ela deve ser cumprida é juridicamente relevante, especialmente, em um cenário em que há uma íntima relação entre Administração e cidadão. Pense-se, por exemplo, que a definição dos documentos necessários para fruir de um determinado benefício assistencial condiciona, de modo juridicamente relevante, o acesso a ele.

\footnotetext{
${ }^{290}$ ATALIBA, Geraldo. Decreto Regulamentar no Sistema Brasileiro, in Revista de Direito Administração, n. $^{\circ}$ 97, jul.-set./1969, p. 23.
} 
Assim, a suposição de que o trato interno de uma lei e as condições adotadas pela Administração para sua execução são indiferentes do ponto de vista jurídico, parece equivocada. O conteúdo vertido por regras para fiel execução da lei detém mabifesta relevância jurídica, sendo equivocado tomá-lo como indiferente, como algo de menor importância; aliás, muitas vezes o acesso do administrado à Administração é definido justamente por regras dessa natureza. Desde o ponto de vista do administrado, os atos administrativos que definem o horário de funcionamento de uma repartição, quantas pessoas serão atendidas ao dia, quais os documentos a serem apresentados, qual o formulário para apresentar o requerimento etc. são todos dotados de inegável importância.

Nesta linha, é de se recusar que a função exercida pelos regulamentos de mera execução nada acresça à lei e que não configure qualquer margem de definição de conteúdo jurídico. Substancialmente, sob esse ponto de vista, não parece haver distinção em relação ao conteúdo dos regulamentos de execução acometidos ao Chefe do Executivo dos expedidos pela Administração, em ambos os casos expedem-se comandos juridicamente relevantes.

Dito isto, importa, então, analisar a questão sob o ângulo da indelegabilidade dos poderes e da ofensa à separação das funções estatais. Como visto, infere-se da separação de poderes uma vedação implícita à delegação de atribuições normativas à Administração, argumento que se densifica ao se aludir ao fato de o ADCT ter cassados as delegações de missões legislativas anteriores à promulgação do Texto Constitucional. Nesta linha, qualquer atribuição de competência normativa à Administração seria uma fraude a esse princípio da vedação à delegação. ${ }^{291}$

Primeiramente, ao contrário de Constituições anteriores o princípio da indelegabilidade das atribuições do Legislativo não foi plasmado de modo explícito na Constituição. Seria assim inferido diretamente da separação de poderes, vedando que houvesse regulamentos para além da mera execução. Não parece ser esta, todavia, a melhor interpretação possível acerca

\footnotetext{
${ }^{291}$ Eros Roberto GRAU alude que a atribuição por lei à disciplina suplementar por parte da Administração não configura delegação de ordem alguma, por ser a possibilidade de expedir normas também uma competência do Executivo. Nesta linha, o autor enfrenta o argumento da indelegabilidade negando que haja delegação. Não parece ser a melhor solução. De fato a técnica do "regulamento autorizado" (ou "delegado") prevê que a lei atribua a Administração uma atribuição que em princípio é própria do Legislativo, que necessariamente deve criar uma regra de competência legal que legitime a expedição do ato regulamentar. Esta criação de uma regra de competência própria implica em trespasse de uma parcela de competência do Legislativo para a Administração, o que se compreende na figura da delegação. Se assim não fosse, seria de se reconhecer a capacidade de a Administração expedir regulamentos sem título legal que a autorizasse a tanto, sendo aí o regulamento autônomo e não autorizado.
} 
do tema. Isto, pois, onde não há limite expresso em relação às tarefas aquinhoadas ao Legislativo não é lídimo supô-lo. Não parece que no sistema pátrio está vedado ao Legislativo atribuir competência à Administração, para regular certas matérias, desde que isto não configure a renúncia pura e simples à função legislativa. Assim, em seu juízo de avaliação política, pode o Legislativo optar por criar competências à Administração para regras certas situações específicas, dentro dos limites previamente estabelecidos, que possibilitem o controle (tanto parlamentar, quanto judicial). É o reconhecimento, por parte do Parlamento, que certas matérias, em vista de elementos que lhes são peculiares (v.g. alta complexidade técnica, transitoriedade, necessidade de atuações diretas dos interessados) serão mais bem tratadas por meio de normas mais flexíveis do que as contidas em lei (submetida a um procedimento mais complexo de produção). Novamente, cumpre trazer à lembrança o fato de que o Estado nos dias de hoje tem deveres de atuação e que estes podem ser melhor tutelados por meios de esquemas que prestigiem soluções dotadas de maior flexibilidade do que a exclusiva disciplina em lei.

Aliás, exemplo trazido do direito penal, elucida que a atribuição de certos elementos técnicos para a disciplina administrativa, nada tem de irregular. Cuida-se da chamada norma penal em branco em que o comando da norma atribui a definição de elementos que integraram o tipo para outro diploma, inclusive de ordem administrativa (nesse caso chamada de norma penal em branco imprópria). Neste caso de norma penal em branco imprópria, nem todos os elementos do tipo são definidos em lei, haja vista a dinâmica da vida social, integrando a estrutura normativa, para fins de imposição de pena, elementos que são descritos pela Administração. A lei penal (sujeita, sem dúvida, à estrita legalidade) remete certos aspectos técnicos à disciplina administrativa (p. ex. definição de doenças contagiosas, lista de substâncias entorpecentes, de tabelamentos, etc.). A justificativa para adoção de técnicas dessa ordem inclusive, faz-se símile à discussão travada no Direito Administrativo, como se vê da seguinte passagem de Luiz Régis PRADO:

Em princípio, o direito penal deve definir de modo autônomo os pressupostos de suas normas, evitando a remissão a outras regras do ordenamento jurídico. Ainda assim, a regulação jurídico-penal de certas matérias (v.g. economia popular, meio ambiente, relações de consumo, saúde pública, ordem tributária), altamente condicionadas por fatores histórico-culturais, que exigem uma atividade normativa constante $\mathrm{e}$ variável, costuma ser realizada por imperiosa necessidade técnica através do modelo legislativo 
denominado lei penal em branco"292 O direito penal reconhece que, haja vista a dinâmica social, por vezes, nem sempre convém à lei verter todos os elementos do tipo, justificando-se nestes caso a definição de certos elementos que integram a descrição da conduta delituosa pela Administração.

O exemplo trazido do campo do direito penal tem o condão de demonstrar que mesmo em campos onde se opera com reserva absoluta de lei, em vista de certas circunstâncias, o atingimento dos fins maiores do ordenamento impõe uma articulação entre lei e atividade administrativa de índole normativa. Tal proceder não repugna o direito brasileiro que conhece exemplos de normas penais em branco, cuja integração do tipo é feita por meio de atividade da Administração. Basicamente, é o que se põe na discussão de fundo acerca da função normativa do Executivo. Há casos em que cumpre reconhecer-se uma margem de atuação normativa da Administração para garantir os objetivos da lei, o que, aliás, justifica a própria existência de discricionariedade e do poder regulamentar para a fiel execução da lei.

Em relação à prescrição do art. 25 do ADCT, usualmente invocada para sustentar a inviabilidade de qualquer atribuição de capacidade normativa à Administração, tem-se que a prescrição não comporta a conclusão que dela usualmente se infere. Tome-se, para fins elucidativos, o pensamento de Clèmerson Merlin CLÈVE acerca do tema: "Ora, se o constituinte revogou, incondicionalmente, as delegações do passado, é porque quer também proibi-las no presente e para o futuro". ${ }^{293}$

Sem embargo dos que pensam em sentido diverso, do fato de o constituinte ter revogado as delegações do passado só se infere que as delegações anteriores à Constituição ficaram sem efeito, salvo prorrogação por lei. Concluir da revogação das delegações pretéritas efeitos futuros não parece ser legítimo; a norma tem nítido caráter conjuntural cuidando da estatuição de regime de transição e não disciplinando o exercício das funções estatais (o que foi feito ao longo do corpo da Constituição). Da derrogação das delegações pretéritas, só isso se conclui; não sendo lídimo dilargar o dispositivo para alcançar situações que nele não estão previstas.

Aliás, se a Constituição vedasse de fato a atribuição de margens normativas à Administração sequer seria de cogitar da possibilidade de prorrogação, desde que expressa, das normas que possuem esse conteúdo. Ora se houvesse impossibilidade absoluta de leis

\footnotetext{
${ }^{292}$ PRADO, Luiz Régis. Curso de Direito Penal. Parte Geral. São Paulo: RT, 1999, p. 92-93.

${ }^{293}$ CLÈVE, Clèmerson Merlin. Op. cit., p. 306.
} 
criarem atribuições normativas para a Administração no sistema instituído pela Constituição de 1988, não seriam admitidas quaisquer prorrogações de prazo levadas a efeito por lei.

Nesta linha, a atribuição de pautas a serem especificadas normativamente pela Administração não implica em ofensa a indelegabilidade de poderes e nem constitui o art. 25 do ADCT vedação expressa a essa prática, eis que se trata de norma conjuntural que expressamente admite que leis mantenham em vigor as delegações normativas feitas à Administração.

O ponto fundamental acerca da separação de poderes parece ser o efetivo controle do exercício de funções normativas exercidas pelo Executivo, que não podem estar sujeitas à completa ausência de peias. Ora, ao estatuir o art. $2^{\circ}$ da Constituição, que: "São Poderes da União, independentes e harmônicos entre si, o Legislativo, o Executivo e o Judiciário" o que se exige é a articulação entre as diferentes funções estatais.

A idéia associada à separação de atribuições implica em controles recíprocos de modo que não se quebre a harmonia (freios e contrapesos) e não na separação estanque e impenetrável entre as tarefas. Aliás, ao se exigir harmonia reconhece a Constituição que há a possibilidade de uma função, materialmente considerada, ser acometida a mais de um poder. É, precisamente, a possibilidade teórica de um compartilhamento de atribuições que impõe o ideal de atuação harmônica entre os Poderes. Note-se, que em um panorama de divisão estanque não há de se exigir harmonia, pois, logicamente, sequer se cogita de qualquer possibilidade de haver desarmonia.

A chave da harmonia do sistema, parece residir no controle possível acerca da atuação concertada entre os Poderes, motivo pelo qual assumem grande importância os sistemas de controle recíprocos havidos entre os assim chamados Poderes. Logo, a previsão de competência para o Congresso Nacional sustar os atos normativos aquinhoados ao legislativo reforça a possibilidade de se permitirem delegações dessa tarefa à Administração (CF, art. 49, $\mathrm{V})$.

Sintetizando acerca do aspecto de garantia da separação dos poderes diz Nuno PIÇARRA: "Na sua dimensão orgânico-funcional, o princípio da separação dos poderes deve continuar a ser encarado como princípio de moderação, racionalização e limitação do poder 
político-estadual no interesse da liberdade. Tal constitui seguramente o seu núcleo imutável."294

Sintetizando, crê-se que o Texto Constitucional não vedou em absoluto articulações normativas entre o Legislativo e a Administração. A tese de que da separação de poderes decorreria de modo implícito uma impossibilidade de qualquer possibilidade de atribuição de competência normativa à Administração (salvo regulamentos para fiel execução da lei) não se afigura plausível. A uma, o núcleo duro do da separação de poderes é preservar a harmonia entre o exercício das diversas tarefas estatais, não se proscrevendo a possibilidade de articulações entre elas. A duas nada no texto positivo da Constituição induz a essa conclusão.

Embora o tema do exercício de capacidades normativas seja absolutamente prenhe de controvérsias não parece que a recusa absoluta em reconhecer a possibilidade de a Administração produzir comandos gerais e abstratos para além do conceito de "fiel execução da lei" deva ser vedada de modo absoluto. Sem prejuízo de toda a discussão já expendida acima em última instância o tema se situa na capacidade de a Administração dar conta das missões a ela reservadas pela complexidade da sociedade atual. Com efeito, conceber a separação de poderes e a legalidade como obstáculos intransponíveis a qualquer atuação normativa da Administração implica em admitir que a ela não compete qualquer missão em promover o desenvolvimento, competindo essa missão apenas ao Legislativo.

Com a devida vênia dos que pensam em contrário, não parece ser esse o espírito da Constituição, em especial em vista do atual momento.

\subsection{CONTROLE DA REGULAÇÃO}

Encerrando a análise da regulação enquanto uma função administrativa importa analisar o controle do seu exercício. Nesse sentido, como já ressalvado, não se produzirá um escorço acerca da questão do controle da Administração, importando pôr em foco o quê de relevante é agregado pela regulação enquanto um modo próprio de atuação administrativa . Isto é, quais as peculiaridades da regulação no que toca ao seu controle, destacando que tais especificidades não têm o condão de romper, em absoluto, com as técnicas já incorporadas ao

\footnotetext{
${ }^{294}$ PIÇARRA, Nuno.Op. cit., p. 26.
} 
Direito Administrativo. ${ }^{295}$ Com efeito, a regulação, na medida em que traduz uma atuação administrativa, submete-se às técnicas de controle da Administração já consagradas no direito pátrio.

Mais ainda. A neutralidade exercida pela Administração ao exercer a função de regulação (que implica que do ponto de vista subjetivo os entes que exercem regulação usualmente sejam tidos por independentes) não atenua em nada a sua submissão a expedientes de controle. Equívoco dos mais canhestros é pretender que a regulação implique em alguma espécie de fuga de controle, legitimada por títulos vagos como independência, neutralidade, atividade técnica e quaisquer outros que lhes sejam correlatos. ${ }^{296}$ É essencial à regulação como a qualquer outra manifestação de poder estatal - à submissão a esquemas de controle. Esta, seguramente, é uma conquista inalienável do Estado de Direito. ${ }^{297}$

Tais considerações devem restar solarmente claras para se enfrentar o tema do controle da regulação.

Como visto acima, a regulação é caracterizada por ser uma atuação com vistas a ordenar determinada atividade econômica para a satisfação de interesses públicos que, naturalmente, não seriam atendidos, desempenhada por atos normativos, de execução e de composição de conflitos, assumindo as mais diversas modalidades e configurações, preferindo atos de intervenção indireta e de incentivo sem, todavia, excluir a imposição coercitiva e a intervenção direta, incidindo sobre agentes públicos e privados e garantindo, ao máximo, a real alteração dos conteúdos regulados, legitimando-se pelos resultados (eficiência).

Tais peculiaridades têm repercussões na estrutura de controle da atividade regulatória, que não se amolda, de modo perfeito, nos esquemas tradicionais de aferição da regularidade formal da atuação administrativa. Embora não haja ruptura com as técnicas de controle já

\footnotetext{
${ }^{295}$ Neste exato sentido se manifesta Marcus Juruena Villela SOUTO. Op. cit., p. 340.

296 Analisando a questão da legitimidade democrática das Agências Reguladoras, Marçal JUSTEN FILHO expressamente refuta qualquer possibilidade de se pretender que o exercício da regulação implique em qualquer forma de fuga de controle (Agências Reguladoras e Democracia: Existe um Déficit Democrático na "Regulação Independente", in O Poder Normativo das Agências Reguladoras, Rio de Janeiro: Forense, 2006, p. 320).

${ }^{297}$ Vital MOREIRA e Fernanda MAÇÃS expressam refutação clara a quaisquer linhas que pretendam subtrair reguladores independentes (chamadas de AAIs, i.e Autoridades Administrativas Independentes) das técnicas de controle: "A independência da AAI encontra-se limitada, desde logo, pela existência do controlo jurisdicional dos seus actos, nos termos gerais da judicial review da actividade administrativa. Não obstante alguns autores advogarem a imunidade jurisdicional das AAI, por força de sua independência, a verdade é que esta tese afigura-se incompatível com a natureza administrativa que a maioria reconhece a estas entidades e, bem assim, com o princípio do Estado de direito." (in Autoridades Administrativas Independentes - Estudo e Projecto de LeiQuadro, Coimbra: Coimbra, 2003, p. 37.)
} 
consagradas no Direito Administrativo pátrio é de se ver que há novas possibilidades neste campo advindas das peculiaridades da própria regulação. O controle é distinto na mesma medida em que a regulação não se amolda perfeitamente às categorias tradicionais do Direito Administrativo. ${ }^{298}$

A primeira peculiaridade digna de análise reside em como se deve controlar uma atividade que, manifestamente, não assume previamente um objetivo unívoco a ser alcançado. O dilema reside na impossibilidade de se controlar a regulação pelo contraste direto com uma finalidade assumida previamente como adequada. O mero contraste de legalidade não é capaz de dar resposta plenamente satisfatória à questão. ${ }^{299} \mathrm{Em}$ especial a lógica fiscalização de adequação à legalidade não basta para o controle da regulação, na medida em que não é satisfatória para assegurar a efetiva implementação de programas de alteração social. É o que destaca Jorge Reis NOVAIS acerca do controle apenas no plano da legalidade:

(...) a prossecução dos interesses burgueses não exigia tanto a subordinação do Executivo ao Parlamento em termos de responsabilidade política, quanto em termos de submissão de Administração à lei. De facto, e dada a separação de Estado-sociedade, à burguesia não interessava tanto controlar a execução de um programa político (que não existia em termos de configuração da sociedade, mas se resumia à garantia das condições de segurança que permitissem o livre desenvolvimento das relações de concorrência entre particulares), quanto assegurar que os direitos individuais - a liberdade e a propriedade - não seriam invadidas ou perturbadas por uma actividade arbitrária ou não prevista da Administração (como acontecia no Estado de Polícia). ${ }^{300}$

Com efeito, o controle tradicional de legalidade não tem aptidão de criar um efetivo sistema de garantia da implementação dos programas de transformação social impostos à Administração desde a emergência do Estado Social e nem está focado em sindicar o processo de determinação do interesse a ser implementado. O problema das finalidades no controle

\footnotetext{
${ }^{298}$ O tema foi enfrentado de modo específico por Floriano Peixoto de Azevedo MARQUES NETO. Em sua análise são peculiaridades do controle da regulação: (i) controle atual ao exercício da regulação e não apenas $e x$ post factum; (ii) necessária participação do administrado na fiscalização; (iii) superação da verificação exclusiva da adequação à lei, pondo-se em causa o próprio conteúdo do exercício da função regulatória; (iv) respeito às margens legítimas de atribuição de capacidade normativa ao regulador; (v) respeito à independência do regulador (in Pensando..., p.219 e 220).

${ }^{299}$ Sobre o tema manifesta-se Paulo Todescan Lessa MATTOS: "a concepção de legitimidade que fundamenta esse modelo tem por base uma racionalidade jurídica tipicamente lógico-formal. Ou seja, basta que a norma de conjuntura ou a política pública definida pelo Poder Executivo estejam logicamente adequados aos objetivos, diretrizes, e prioridades definidos no texto constitucional e aprovados em lei pelo Poder Legislativo, que tal norma ou tal política reputar-se-ão legítimas. É, assim, um conceito de legitimidade restrito a juízos formais de legalidade. (...) é um conceito limitado para garantir, no plano do sistema jurídico, que princípios constitucionais, normas programáticas, objetivos, diretrizes, e prioridades sejam a bases de processos deliberativos democráticos sobre o conteúdo da regulação." (Op. cit., p. 350- 351).

${ }^{300}$ NOVAIS, Jorge Reis. Op. cit. p. 92.
} 
ortodoxo confunde-se com o problema da legalidade na medida em que o fim deve estar vertido na norma que atribui competência para atuação administrativa. Manifestamente, esse expediente não tem aptidão de levar a cabo um efetivo controle da atuação regulatória, conduzindo à tentação de invocar uma fuga de controle tendo em vista a ausência de atribuição cerrada de competência para aquele que está incumbido de dar concretude à regulação.

Embora a legalidade ainda imponha uma técnica de controle da atuação regulatória na medida em que a função administrativa não rompe com a necessária articulação entre Administração e lei, ${ }^{301}$ o seu controle não se exaure apenas nessa dimensão. Em especial, a atribuição de competência regulatória, por se dar sem a imposição de finalidades previamente definidas, não pode ser reduzida ao controle, apenas, pela técnica da legalidade. Ou seja, ao controle de legalidade há um plus a ser agregado.

Nessa linha, é necessário acrescer elementos ao controle da atividade administrativa regulatória. Em vista do exposto, dois núcleos parecem trazer novas cogitações acerca da questão do controle. A uma, deve haver controle desde o plano da definição dos objetivos a serem alcançados. A duas, deve haver controle acerca da efetividade da implementação da regulação. ${ }^{302}$

O enfrentamento da primeira questão (definição dos objetivos), invariavelmente, conduz à invocação da questão da procedimentalidade no exercício da regulação como instrumento tanto de adequação dos fins eleitos como de reforço da garantia da sua eficácia. $\mathrm{O}$ procedimento de eleição dos fins pelas agências é importante e submete-se a controles que visam a manter a eficácia desse modo de atuação. ${ }^{303}$

\footnotetext{
${ }^{301}$ Neste sentido, manifesta-se Sérgio Varella BRUNA: "A análise dos procedimentos decisórios como forma de avaliar a validade dos atos normativos não significa que se possa abdicar da avaliação dos limites materiais estabelecidos pela lei e, de forma geral, pelo ordenamento jurídico, para o exercício de função administrativa." (Agências..., p. 266.)

${ }^{302}$ Diogo de Figueiredo MOREIRA NETO analisando as transformações pelas quais vem passando o Direito Público advoga a tese de que toda atuação estatal deve ser permeável à participação social, sendo essa uma dimensão essencial à legitimidade do Estado. Neste sentido afirma: “(...) é necessário que qualquer norma, oriunda ou não dos parlamentos,seja democraticamente legitimada pela observância do devido processo legal, em que a participação cidadã seja assegurada na medida do possível e do razoável, se não na tomada de decisão, pelo menos e inafastavelmente no controle social dos decorrentes resultados das políticas públicas executadas." (Mutações..., p. 49.)

303 Sobre a legitimação procedimental anota Sérgio Varella BRUNA "o papel das decisões é reduzir a insegurança de seus destinatários, condicionando os respectivos comportamentos, essa função é realizada substituindo a incerteza sobre o conteúdo da decisão pela certeza do advento de uma decisão, o que leva os
} 
A relação de atingimento das finalidades da regulação (inerente ao seu controle) passa por uma etapa que não está contida, diretamente, na lei que cria a competência regulatória. Logo, é necessário, antes de qualquer outra consideração, analisar a própria formação dos objetivos assumidos pela regulação como adequados para enfrentar uma determinada questão.

Como tal definição decorre de um jogo institucionalizado entre os diversos interesses postos em contraste pelo regulador, é necessário analisar prejudicialmente o procedimento que leva à formação da regulação na sua aptidão para gerar respostas desejáveis. Em sendo a fixação desses objetivos procedimental, importa tomar esse elemento em mira com vistas a controlar a regulação.

Desse modo, o primeiro teste ao qual a regulação deve ser submetida se dá no plano da formação das técnicas que darão concretude à regulação; impõe-se o controle, de fato, da definição do interesse que será imposto aos particulares. Devem ser concebidos instrumentos de controle que sejam aptos a avaliar se, dentre os diversos interesses a ser considerados, se todos foram avaliados de modo adequado e o resultado proclamado é coerente com a discussão travada. Como adverte Marçal JUSTEN FILHO: “O controle terá de fazer-se não só sob o ângulo da fiscalização contemporânea ou posterior à atuação das agências. Devem ser estruturados sistemas que permitam aos diversos segmentos da sociedade acompanhar a regularidade da gestão e a satisfatoriedade da atuação das agências no cumprimento de seus fins.",304

O risco a ser elidido diz com impedir que a regulação seja um jogo de cartas marcadas em que há por parte do regulador a assunção velada de um interesse como preponderante antes de se ouvirem todos os interessados. Ora, se regulação implica na ausência tarifamento prévio de finalidades a serem implementadas tendo em vista conflituosidade ínsita aos interesses em jogo a formação livre do entendimento que deve prevalecer deve ser objeto de controle.

Sobre essa perspectiva é que assume transcendental importância tutelar a efetividade dos procedimentos adotados pelos reguladores para formação das finalidades que eles atuarão. O que deve ser garantido é a possibilidade de compreensão do porquê da adoção de determinada solução em vista dos interesses que estão em conflito, que devem ter sido representados na discussão.

destinatários a assumirem os papéis que lhes são assinalados no âmbito dos procedimentos, na expectativa de poderem influir, efetiva ou simbolicamente, no resultado a ser obtido." (In Agências..., p. 183.)

304 JUSTEN FILHO, Marçal. O Direito..., p. 585. 
É, exatamente, em vista a esse problema que, usualmente, as estruturas incumbidas de concretizar a função de regulação prevêem a adoção de esquemas procedimentais para a produção da regulação que visam a incentivar a participação popular, ${ }^{305}$ garantindo transparência às decisões. ${ }^{306-307}$ Marçal JUSTEN FILHO expressamente referencia a necessária permeabilidade dos procedimentos decisórios das agências aos interessados à qualidade de suas decisões: "Essa solução propiciará uma atuação imediata da sociedade perante a agência, inclusive pela institucionalização da produção processualizada de decisões. A participação permanente de determinados sujeitos assegura uma atuação congruente, dotada de racionalidade. Evita-se, desse modo, que o princípio do devido processo legal se transforme num conjunto de formalidades destituídas de utilidade." 308

Não por outra razão, a ausência de solução legal em relação a algumas agências reguladoras brasileiras e o déficit de efetiva participação nos procedimentos de tomada da decisão são alvos de severa crítica doutrinária. ${ }^{309}$

Nessa perspectiva o controle da formação dos interesses atuados deve ser efetivo e não apenas formal. Apenas a encenação ritualística de uma decisão procedimental acerca de uma política regulatória não basta para atender as exigências do controle da atividade de regulação.

\footnotetext{
305 A efetividade desses processos foi objeto de análise expressa por Egon Bockmann MOREIRA que empreendeu pesquisa acerca da participação popular no âmbito das decisões formadas pelas Agências Reguladoras especialmente focada no instrumento das audiências públicas. A conclusão maior alcançada pelo autor foi que, malgrado a possibilidade de participação popular esteja prevista em diversas normas, usualmente, os únicos interessados em tomar parte nesses procedimentos são partes diretamente interessadas na regulação. Tomando por base o setor elétrico, no ano de 2002 (em que nele houve séria crise), constatou-se que $86 \%$ das contribuições feitas nas audiências públicas realizadas foram apresentadas por empresas e associações interessadas no setor. Esse número contrasta com o percentual de colaborações apresentadas por Associações de Consumidores, que foi de apenas 1,2\%. Com base nesse referencial, concluiu o autor que há efetivo um déficit democrático nestes procedimentos. No plano fático tais expedientes não são suficientemente permeáveis à participação popular, limitando-se a uma garantia formal de participação, que não se traduz em discussão efetiva com a sociedade (in Os limites..., p. 209 a 214).

${ }^{306}$ Diogo de Figueiredo MOREIRA NETO empreendeu classificação de nossas Agências Reguladoras em que um dos critérios utilizados diz, exatamente, com a avaliação da possibilidade efetiva de análise e participação no procedimento de formação da regulação. Para avaliação específica do tema consulte-se Direito Regulatório. Op. cit., p. 192-216.

307 Sérgio Varella BRUNA empreendeu interessante estudo acerca da participação popular na formação dos objetivos da regulação e o controle dessa atuação com vistas ao modelo norte-americano (in Agências..., p. 180249).

${ }^{308}$ JUSTEN FILHO, Marçal. O Direito..., p. 586.

${ }^{309}$ Sobre a ausência de efetividade consulte-se o texto de Egon Bockmann MOREIRA (in Os limites..., p. 209214). Para uma crítica acerca da inadequação de previsões normativas acerca do tema consulte-se Marçal JUSTEN FILHO (in $O$ Direito..., p. 587). Contudo, embora este autor reconheça a insuficiência dos referenciais legais que disciplinam a atuação das agências reguladoras, no mesmo trecho indicado manifesta seu entendimento de que o suporte constitucional que disciplina a participação popular na administração seria suficiente para assegurar sua implementação.
} 
Não se pode no campo da regulação analisar esses esquemas procedimentais de um modo meramente mecânico. Entendimentos que vêem o procedimento de formulação da regulação apenas como mera sucessão de formalidades, que se inobservadas não induzem a pronúncias de invalidade, devem ser rechaçados. ${ }^{310} \mathrm{~A}$ ausência de efetiva participação popular e de transparência na implementação concreta da regulação não é passível de ser convalidada. Em caso de o controle exercido pela própria Administração não reconhecer essas pautas axiológicas impõe-se ao Judiciário a pronúncia de invalidade da atuação regulatória por não traduzir em concreto as imposições de transparência decorrentes de sua própria natureza. Sobre o tema anota Sérgio Varella BRUNA:

\begin{abstract}
Mais do que uma simples 'concessão' inspirada pelo espírito democrático do legislador ou da autoridade administrativa, tais procedimentos devem ser encarados como um importante instrumento de orientação da revisão judicial dos atos normativos, especialmente diante de competências discricionárias, pois são eles capazes de fornecer elementos ao Judiciário para avaliar a higidez tanto do processo normativo quanto da própria norma em si mesma. ${ }^{311}$
\end{abstract}

O referido controle se dá, em especial, analisando se realmente houve possibilidade de os interessados se fazerem representar e analisando-se as motivações dos atos derivados do exercício da função regulatória de modo a se aferir se houve congruência entre o que foi decidido e a estrutura da discussão levada a efeito.

Uma vez vista a lógica do controle da definição dos objetivos da regulação, é de se analisar em que a exigência de efetividade acresce os esquemas de controle do exercício da função administrativa. Como visto, uma das peculiaridades da atuação em regime de função regulatória diz com a necessidade de efetiva implementação das pautas axiológicas assumidas como adequadas. A mera produção de atos administrativos não esgota a função regulatória que se legitima também em vista do grau de efetividade alcançado pela atuação da Administração.

Como bem observado por Tércio Sampaio FERRAZ JÚNIOR submete-se a regulação a uma validação finalística. Dá-se tal sorte de legitimação quando: "uma norma valida outra se preestabelece fins que devam ser alcançados, devendo ser encontrados os meios adequados. Neste caso, a validade da norma subseqüente localiza-se na solidariedade entre fins e meios, donde a questão da validade levantar problemas de proporcionalidade, razoabilidade,

\footnotetext{
${ }^{310}$ Sérgio Varella BRUNA destaca que "Até o momento, no entanto, parece que o estabelecimento do requisito da participação popular nos procedimentos normativos vem sendo encarado como ato de mera liberalidade do Poder Público, que assim se dispõe a ouvir os interessados.” (Agências..., p. 251.)

${ }^{311}$ Ibidem, p. 271.
} 
adequação etc."312 Deste modo, o controle da atividade regulatória há de levar em conta a relação estabelecida entre o produto emanado da atividade regulatória a real alteração do ambiente regulado. Exige-se eficiência na promoção dos fins sociais impostos pela regulação o que se afere para adequação de uma relação de pertinência entre fins e meios.

Nesta linha é que diversos estudiosos da questão do controle da regulação apelam às idéias de proporcionalidade como intimamente associada ao seu exercício. Tércio Sampaio FERRAZ JR. expressamente apela à relação de adequação que integra a proporcionalidade como um enfoque apto a desvelar a efetividade da regulação. O exercício da regulação será legítimo apenas se os instrumentos de que as autoridades administrativas lançarem mão sejam idôneos para promover as alterações esperadas. Segundo o autor, pressupostos de razoabilidade impõe ao exercício da regulação um juízo de realidade que opera como limite à margem de avaliação de que é dotado o regulador. Neste sentido é que faz consignar:

Já o sentido de legitimação da legalidade vê na lei não tanto uma condição de e um limite, mas, basicamente, um instrumento de exercício da atividade administrativa. Como instrumento, seu princípio hermenêutico está na solidariedade entre meios e fins, donde a razoabilidade da atividade administrativa, submetida, então, a uma avaliação de sua eficiência. Nestes termos, o respeito à legalidade exige do intérprete uma distinção entre conceitos indeterminados e discricionários, bem como uma concepção da discricionariedade que não se limita a um juízo de oportunidade, mas alcança um os juízos de realidade (avaliação de políticas de implementação de objetivos, de adequação dos meios escolhidos em face dos fins propostos). ${ }^{313}$

Ainda nesta linha, além da razoabilidade, alguns autores trazem a idéia de proporcionalidade como padrão de controle da regulação. Novamente, o pano de fundo é a necessária adequação da relação meios/fins como um problema inerente à regulação. A proporcionalidade é um postulado normativo ${ }^{314}$ que induz a três exames distintos (adequação, necessidade e proporcionalidade em sentido estrito). A adequação exige que uma medida dê ensejo (ou tenha a virtualidade de) às alterações objetivadas, como assinala Humberto B.

\footnotetext{
${ }^{312}$ FERRAZ JÚNIOR, Tércio Sampaio. In O Poder..., p. 289.

${ }^{313}$ Ibidem, p. 290-291.

${ }^{314}$ Tecnicamente, não se configura a proporcionalidade como um princípio jurídico, na linha do magistério de Humberto B. ÁVILA. Para este autor, tecnicamente, a proporcionalidade é um postulado normativo aplicativo, que se configura por ser uma meta-norma, não estabelecendo de modo direto um fim a ser implementado (essência normativa), e sim dizem respeito a como devem ser aplicadas as normas. Sobre o tema, anota o autor: "os postulados, de um lado, não impõem a promoção de um fim, mas, em vez disso, estruturam a aplicação de um dever de promover um fim; de outro, não prescrevem diretamente comportamentos, mas modos de raciocínio $e$ de argumentação relativamente a normas que indiretamente prescrevem comportamentos. Rigorosamente, portanto, não se podem confundir princípios com postulados." (in Teoria dos princípios - da definição à aplicação dos princípios jurídicos. 4. ed. São Paulo: Malheiros, 2004, p. 88.)
} 
ÁVILA “A medida será adequada somente se o fim for efetivamente realizado no caso concreto" $^{315}$. A necessidade diz com a inexistência de opções alternativas para implementar os fins almejados com menor incidência de restrição aos interesses afetados à medida. ${ }^{316}$ Por fim, tem-se a chamada proporcionalidade em sentido estrito que diz com a própria comparação do fim eleito com o nível de restrição a ser suportado pelos interessados (o que se acentua em se tratando de intervenção sobre direitos tidos por fundamentais). Valem-se, por exemplo, expressamente de invocações de proporcionalidade como meio de controle da regulação Alexandre Santos de ARAGÃO ${ }^{317}$ e Floriano Peixoto de Azevedo MARQUES NETO ${ }^{318}$ encarecendo que a pertinência entre os fins e os meios é um núcleo de controle da regulação. Outro efeito da invocação da proporcionalidade no pensamento desses autores é sua dimensão de garantia assegurada pelo postulado, apresentando-se assim como limites à intervenção regulatória, os direitos fundamentais daqueles que detêm interesse na situação regulada. A proporcionalidade serve tanto como meio de aferir a adequação entre meios e fins contidas no exercício da regulação como meio de sindicar se o exercício de tais atividades não vulnera de modo excessivo ou mesmo ocioso os diversos interesses postos em jogo.

A avaliação de efetividade concreta do exercício da regulação deve, pois, submeter-se a controles decorrentes da invocação da aplicação do postulado da proporcionalidade. Em especial, é de se notar que usualmente - até pela importância dos valores arrolados no art. 170 da Constituição - regulação incide sobre direitos fundamentais dos interessados devendo se submeter a controles que garantam o menor nível de sacrifício possível a esses valores. Assim, nos casos de manifesta inadequação dos meios eleitos pelo regulador para alcançar os fins almejados a sua atividade pode ser controlada. Seria contrário à exigência de eficiência ínsita à regulação permitir que o seu exercício se desse de modo descolado de métodos de controle que visam sindicar a capacidade de as medidas tomadas realmente conduzirem aos objetivos almejados.

\footnotetext{
${ }^{315}$ Ibidem, p. 118.

${ }^{316}$ Ibidem, p. 122-124.

${ }^{317}$ ARAGÃO, Alexandre Santos de. In Agências..., p. 115-117.

${ }^{318}$ MARQUES NETO, Floriano Peixoto de Azevedo. Limites à abrangência e à intensidade da regulação estatal. MOREIRA, Vital; JUSTEN FILHO, Marçal; MOREIRA, Egon Bockmann (coord.). Revista de Direito Público da Economia. Belo Horizonte, 1/69, jan.-mar./2003. O autor se vale da proporcionalidade como limite vertical à incidência da regulação. No referido texto, ainda se traz a subsidiariedade como meio de controle das atividades submetidas à regulação.
} 
Ainda na linha do controle da efetividade da regulação, é de se destacar que além de estar franqueado espaço para o controle social, avulta a importância do controle exercido pelo Legislativo. ${ }^{319} \mathrm{Na}$ medida em que a função de regulação deve alcançar objetivos que implementem as pautas de valor postas para sua atuação urge que essa dimensão seja controlada pelo Legislativo que congrega a expressão maior da sociedade brasileira. Em especial, em face do disposto no art. 49, X da CF/88 que diz ser competência exclusiva do Congresso Nacional "fiscalizar e controlar, diretamente, ou por qualquer de suas Casas, os atos do Poder Executivo, incluídos da administração indireta." Ainda, especificamente, sobre os atos de cunho normativo, o Congresso Nacional poderia controlar sua legitimidade valendo-se do disposto no art. $49, \mathrm{~V}$, da CF/88 ou mesmo do art. 71 , caput. $^{320}$

Por fim, por sua importância constitucional (cf. art. $5^{\circ}, \mathrm{XXXV}$, da $\mathrm{CF} / 88$ ), algo deve ser dito especificamente acerca do controle judicial dos atos regulatórios. Na linha das ressalvas metodológicas apontadas no início do tópico, é de se dizer que, de modo algum, a regulação furta-se ao controle que o Judiciário deve exercer sobre os reguladores. $\mathrm{O}$ fato de uma competência regulatória ser atribuída a alguma autoridade administrativa não lhe subtrai do controle judicial dos seus atos. A clareza da garantia constitucional de acesso à justiça espanca qualquer pretensão nesse sentido. Todas as manifestações de expressão da função de regulação, desde a produção de atos de cunho normativo até decisão de litígios entre particulares, são passíveis de ser apreciadas pelo Judiciário. Regulação não é sinônimo de imunidade jurisdicional.

O controle judicial se dá no âmbito da regulação seguindo a mesma lógica afeita ao controle geral da atividade administrativa; vale dizer, a atuação do Judiciário não pode se substituir ao regulador. Dentro dos limites justos de atuação as decisões do regulador não podem ser substituídas por decisões judiciais. Note-se que isso não implica em angustiar a atuação do Judiciário. Isto, pois, como já destacado o processo de formação da regulação é passível de controle, sendo o Judiciário garante da possibilidade de os diversos interesses em jogo serem considerados. E, no que toca à relação de adequação entre meios e fins que visa a garantir a eficácia da regulação o judiciário pode ser chamado a atuar analisando as atuações

\footnotetext{
319 Sobre o controle do Legislativo sobre a Administração consulte-se Maria Sylvia Zanella DI PIETRO (in Direito Administrativo..., p. 635-636).

${ }^{320}$ Floriano Peixoto de Azevedo MARQUES NETO defende uma leitura ampla do art. 71 da CF, vendo nele uma capacidade geral de o Legislativo controlar os atos da Administração (in Pensando..., p. 245).
} 
regulatórias sob a ótica da razoabilidade e da proporcionalidade, o que não configura adentrar propriamente o mérito das decisões administrativas.

Ainda quanto à atuação do Judiciário uma ressalva há de ser feita acerca da chamada discricionariedade técnica, ${ }^{321}$ por vezes, invocada como óbice à apreciação judicial dos atos produzidos no exercício da regulação. ${ }^{322} \mathrm{Na}$ medida em que a regulação atua em ambientes dotados de inegável complexidade (v.g. telefonia, energia elétrica, combustíveis fósseis etc.) o argumento tem sua invocação revigorada. ${ }^{323}$

Todavia, ao se analisar o tema apenas a uma conclusão se chega: a discricionariedade técnica não induz a qualquer modificação no trato da matéria e sequer tem aptidão a integrar algo de útil no que toca ao exercício de competências administrativas. O tema já mereceu severa censura doutrinária. António Francisco de SOUSA alude à "fragilidade da estrutura de pensamento em que assenta" ${ }^{324}$; Marçal JUSTEN FILHO alude à ser o tema uma "falácia"325

O tema, de fato, não resiste a uma análise atenta, valendo mais pela carga semântica sofisticada do que pela capacidade de explicar algo. Para por a nu o assunto, há de ser lembrada uma ressalva antiga acerca do tema feita de há muito por Renato ALESSI. O autor italiano, embora reconhecendo a existência de uma chamada discricionariedade técnica ${ }^{326}$ cuidou de retirar de seu âmbito diversas manifestações que não caracterizam o fenômeno. Discricionariedade técnica só haveria se sobre a decisão da questão não houvesse qualquer margem de apreciação administrativa, cuidando-se de uma atuação submetida exclusivamente a critérios científicos. Ou seja, qualquer margem de emissão para um juízo administrativo

\footnotetext{
${ }^{321}$ Sobre o tema regulação e discricionariedade na doutrina nacional consulte-se: Marçal JUSTEN FILHO $(O$ Direito..., p. 525-532) e Egon Bockmann MOREIRA (Os Limites..., p. 216-220). Sobre discricionariedade técnica e seu controle jurisdicional consulte-se a abordagem de Santiago Muñoz MACHADO (in Tratado..., p. 597-602). Sobre anotações gerais sobre a discricionariedade técnica consulte-se António Francisco de SOUSA (in Conceitos Indeterminados no Direito Administrativo, Coimbra: Almedina, 1994, p. 105-112).

${ }^{322}$ Vital MOREIRA e Fernanda MAÇÃS são exemplos de autores que invocam a chamada discricionariedade técnica como limite à atuação judicial acerca dos atos regulatórios (Op. cit., p. 37).

${ }^{323}$ Explicando o fenômeno anota Egon Bockmann MOREIRA: "O óbice à investigação estaria no conhecimento detido com exclusividade pela Administração Pública. A discricionariedade técnica impediria o controle justamente porque a Administração titular de uma gama de tarefas práticas de extrema complexidade, dependentes de peculiar conhecimento, oriundo justamente do contacto [sic] diário com a matéria. Essa perícia oriunda de determinados órgãos administrativos impediria que um terceiro, estranho e não afeito a questionamentos técnico-científicos (o Poder Judiciário), enfrentasse tais decisões. (In Limites..., p. 218.)

${ }^{324}$ SOUSA, António Francisco de. In Conceitos..., p. 105.

325 JUSTEN FILHO, Marçal. In Agências..., p. 528.

${ }^{326}$ ALESSI, Renato. Concebida nos seguintes termos: “(...) la referida aprecciación, y por lo tanto la elección de la actividad administrativa a desarrollar, exige la utilización de critérios técnicos y la solución de cuestiones técnicas que deben realizarse conforme a reglas y conecimentos técnicos" (Op. cit., p. 195).
} 
sobre a questão retiraria o tema do âmbito de incidência da chamada discricionariedade técnica. ${ }^{327}$

Mais ainda. Se a questão for de fato meramente técnica é de se ver que sequer seria próprio falar de discricionariedade. Como adverte Renato ALESSI:

(...) es erróneo hablar de una discrecionaliedad meramente técnica, ya que los términos discrecionaliedade y técnica son esencialmente inconciliables. Efectivamente, como hemos dicho, cuando se trata de una cuestión meramente técnica, ésta se resuelve exclusivamente en base a criterios y reglas técnicas, y sin que la Administración pública tenga facultad alguna de apartarse de dichas reglas actuando mal en vez de ajustarse aquéllas, ya que la consideración del interés público no tiene aquí nada que ver. $^{328}$

António Francisco de SOUSA ainda agrega mais elementos no sentido de demonstrar a equivocidade da chamada discricionariedade técnica. A uma, não há conceito preciso do que sejam decisões altamente técnicas capazes de excluir a atuação judicial. A duas, a avaliação do que é uma questão puramente técnica é um conceito de valor. Por fim, a autoridade judiciária pode se socorrer de peritos, como ordinariamente o faz, para compor questões que escapam ao seu expertise. $^{329}$

Com base nisto, demonstra-se que a chamada discricionariedade técnica em se cuidando de regulação não logra granjear muito espaço. Decisões que compõe posições diversas ainda que cuidem de definir elementos técnicos raramente deixarão de ter uma margem de apreciação administrativa. Veja-se que diante de uma questão ainda que técnica que pusesse em confronto a utilização de dois ou mais métodos distintos já não mais poderia ser vista como acobertada pela discricionariedade técnica. A questão técnica ficaria restrita apenas àqueles casos em que se cuidasse de aplicar um juízo científico inconteste a uma determinação o que, como ressalvado por Renato ALESSI, não cria margem alguma de discrição. A neutralidade da Administração ao exercer a regulação não traduz ausência de juízos de valor e sim se configura como garantia de isenção em face dos interesses regulados.

Assim, conclui-se que a chamada discricionariedade técnica não deixa de ser discricionariedade e, com as ressalvas referentes à liberdade de definição do mérito dos atos administrativos, podem ser revisadas em havendo condições para tanto.

\footnotetext{
${ }^{327}$ Ibidem, p. 198.

${ }^{328}$ Ibidem, p. 199.

${ }^{329}$ SOUSA, António Francisco de. In Conceitos..., p. 107.
} 
Voltando ao controle judicial propriamente dito não será ocioso lembrar ao fim que mesmo de defendendo a revisão judicial dos atos que importam na concretização da função de regulação é de se ver que deve haver preocupação com atribuir o devido valor à regulação. A possibilidade de controle não deve levar a nulificação da competência regulatória, substituindo-se os juízes às autoridades administrativas. Afinal, como advertiu com acerto Egon Bockmann MOREIRA:

À evidencia, não se está a defender uma sucessão de discricionariedades: o juiz atua como 'administrador negativo' (ou 'regulador negativo'), vedando os excessos e os abusos porventura cometidos. Não se pretende a substituição de uma decisão eventualmente qualificada pela discricionariedade oriunda da agência por decisões discricionárias do Judiciário. O núcleo duro da discricionariedade permanece intacto (seja ela técnica ou não). ${ }^{330}$

Assim, fazendo síntese acerca da questão ora em análise, é de se indicar que, ao contrário do que se poderia supor, o desempenho da regulação está sujeito a um regime mais rígido de controle do que outras manifestações de atuação administrativa. O exercício desta função além de se submeter a todos os controles ínsitos à Administração é ainda controlado em novas dimensões. Deste modo, regulação não pode significar flexibilização de qualquer ordem no que toca ao controle, antes, pelo contrário, significa seu incremento.

\footnotetext{
${ }^{330}$ MOREIRA, Egon Bockmann. In Os Limites..., p. 219.
} 


\section{CONCLUSÃO}

A função de regulação traduz uma nova forma de inter-relacionamento entre a Administração e a sociedade, típica do modelo de Estado ora vigente. As transformações havidas com a parcial superação do modelo de Estado Social conduzem à necessidade de se repensar o modo pelo qual se expressa a atuação da Administração Pública. Na medida em que se propugna pela diminuição do tamanho do Estado, é preciso conceber novas categorias aptas a explicar como se garantir a implementação de valores sociais à ordem econômica sem a participação direta no mercado de entes públicos.

A regulação então emerge como modo de atuação da Administração buscando a efetiva implementação de valores socialmente desejáveis consagrando esquemas de atuação preferencialmente indiretos.

Analisando as alterações havidas entre os diferentes modelos de Estado e a evolução sentida nas próprias categorias que traduzem em concreto o exercício da função administrativa, percebe-se que a regulação promove uma síntese de noções recondutíveis à noção liberal de poder de polícia e da noção de serviço público, característica do Estado Social. A função de regulação aproxima-se do poder de polícia ao consagrar métodos de atuação indiretos investindo em condicionar a atuação dos agentes que atuam na ordem econômica. Contudo, fundamentalmente, o compromisso de produção de concretas alterações na ordem social separa os conceitos. Veja-se, é missão da regulação implementar de fato condições melhores a serem fruídas em concreto pela sociedade o que não consegue ser explicado pelas possibilidades teóricas contidas no conceito de poder de polícia. Sobre esse aspecto está contida no conceito de regulação uma nota prestacional que a aproxima da noção ampla de serviço público sem, todavia, assumir a titularidade estatal de atividades como pressuposto para a implementação de condições favoráveis à sociedade.

Deste modo a regulação apresenta-se como síntese das noções de polícia e serviço público, típica da adoção de um modelo de Estado Pós-Social.

No plano da análise da regulação enquanto um modo de atuação da função administrativa é de se destacar que este instituto se caracteriza pela permeabilidade às diversas demandas sociais que caracterizam o direito contemporâneo. A impossibilidade de se trabalhar 
com um conceito unívoco de interesse público conduz à necessidade de se conceber a regulação como meio de atuação estatal que rejeita a eleição prévia de finalidades a serem implementadas. É a própria descoberta das finalidades adequadas em determinados ambientes econômicos que caracteriza a regulação. A função de regulação assume então a missão de definir - por meio de um procedimento institucionalizado - quais as finalidades que devem prevalecer em um determinado caso, estando permeável a diversidades de interesses associadas à atuação do Estado. O próprio plexo de valores albergados pela ordem constitucional, por vezes potencialmente conflitantes, exige que a indeterminação de finalidades seja uma nota peculiar à função de regulação.

Desde o ponto de vista dos modos de expressão, a função de regulação vai além da mera aplicação ex officio de normas a situações concretas; ela se empresa também pela edição pelo ente encarregado da regulação de normas, bem como pela possibilidade de compor conflitos advindos de sua implementação. A maior amplitude de competências associadas à regulação decorre de suas características. Em especial, ao se relegar a Administração um papel ativo na concretização dos interesses reputados adequados pela sociedade (que passa além da mera aplicação da lei a casos concretos) alarga-se o modo pelo qual a função administrativa se manifesta. A essas novidades agrega-se a necessidade de um controle mais severo da atividade de regulação que visa assegurar a correção no seu exercício. Além das técnicas de controle já consagradas, tem-se a necessidade de implementar maiores margens de controle por meio da participação social e um reforço no papel do Poder Legislativo no controle de seu exercício.

De tudo o que se viu, conclui-se que a regulação é uma nova forma de manifestação da função administrativa. Embora seja inegável a vinculação da regulação com outras formas de manifestação da função administrativa, nela estão abarcadas notas que a tornam peculiar em relação às manifestações que lhe antecederam. 


\section{REFERÊNCIAS BIBLIOGRÁFICAS}

AGUILAR, Fernando Herren. Controle Social dos Serviços Públicos. São Paulo: Max Limonad, 1999.

ALESSI, Renato. Instituiciones de Derecho Administrativo. Tomo I. Barcelona: Bosch, 1970.

ALMEIDA, Fernando Menezes Dias de. Teoria da Regulação in Curso de Direito Administrativo Econômico. São Paulo: Malheiros, 2006. v. 3.

AMARAL, Diogo Freitas do. Curso de Direito Administrativo, vol 1, Coimbra: Almedina, 1992.

ARAGÃO, Alexandre Santos de. Agências Reguladoras e a Evolução do Direito Administrativo Econômico. 2. ed. Rio de Janeiro: Forense, 2003.

- Atividades Privadas Regulamentadas. ARAGÃO, Alexandre dos Santos (coord.). $O$ Poder Normativo das Agências Reguladoras. Rio de Janeiro: Forense, 2006.

ARIÑO ORTIZ, Gaspar. Principios de Derecho Público Economico: modelo de Estado Gestión Publica, Regulación Economica. 3. ed. Madri: Comares, 2004.

ATALIBA, Geraldo. República e Constituição. 2. ed. São Paulo: Malheiros, 2001.

. Decreto Regulamentar no Sistema Brasileiro. Revista de Direito Administrativo, n. 97, jul./set. 1969.

ÁVILA. Humberto B. Teoria dos Princípios - Da Definição à Aplicação dos Princípios Jurídicos. 4. ed. São Paulo: Malheiros, 2004.

BARACHO, José Alfredo de Oliveira. Princípio de Subsidiariedade. Rio de Janeiro: Forense, 1996.

BOBBIO, Norberto. Teoria da Norma Jurídica. São Paulo: Edipro, 2001.

BRUNA, Sérgio Varella. Agências Reguladoras, Poder Normativo, Consulta Pública, Revisão Judicial. São Paulo: RT, 2003.

CAMPOS, Francisco. Lei e Regulamento - Matéria Reservada à Competência do Poder Legislativo - Limites do Poder Regulamentar - Direitos e Garantias Individuais. Revista Forense, Rio de Janeiro, n. 146, 1955.

CANOTILHO, José Joaquim Gomes. Direito Constitucional e Teoria da Constituição. 5. ed. Coimbra: Almedina, 2002. 
CASSESE, Sabino. Lo spazio giuridico globale. Rivista trimestrale de diritto pubblico. n. 2, 2002.

CASTRO, Carlos Roberto Siqueira. Devido Processo Legal e os Princípios da Razoabilidade e da Proporcionalidade. 3. ed. Rio de Janeiro: Forense, 2005.

CHEVALLIER, Jacques. Vers um droit post-moderne? Les transformations de la régulation juridique. In Revue de droit public. n. 3, 1998.

CLÈVE, Clèmerson Merlin Atividade Legislativa do Poder Executivo. 2. ed. São Paulo: RT, 2000.

COMPARATO, Fabio Konder. O poder de controle na sociedade anônima. 3. ed. Rio de Janeiro: Forense, 1983.

Regime constitucional do controle de preços no mercado. Direito Público - Estudos e Pareceres. São Paulo: Saraiva, 1996.

Função social da propriedade dos bens de produção. Revista de Direito Mercantil RDM 63/75.

CUÉLLAR, Leila. As Agências Reguladoras e seu Poder Normativo. São Paulo: Dialética, 2001.

DI PIETRO, Maria Sylvia Zanella. Direito Administrativo. 17. ed. São Paulo: Atlas, 2004. 2001.

Discricionariedade Administrativa na Constituição de 1988. 2. ed. São Paulo: Atlas,

. Parcerias na Administração Pública, 3. ed. São Paulo: Atlas, 1999.

. Limites da função reguladora das agências diante do princípio da legalidade. Maria Sylvia Zanella di Pietro (coord.). Direito Regulatório. Temas Polêmicos. Belo Horizonte: Fórum, 2003.

ENTERRÍA, Eduardo García de; FERNÁNDEZ, Tomás-Ramón. Curso de Derecho Administrativo I. 12 ed. Madrid: Thomson Civitas, 2005.

ESTORNINHO, Maria João. A Fuga para o Direito Privado - Contributo para o estudo da actividade de direito privado da Administração Pública. Coimbra: Almedina, 1999.

FERRAZ JÚNIOR, Tércio Sampaio. Introdução ao Estudo do Direito. 2. ed. São Paulo: Atlas, 1994. 
, O Poder Normativo das Agências Reguladoras à luz do Princípio da Eficiência. ARAGÃO, Alexandre Santos (coord.) O Poder Normativo das Agências Reguladoras. Rio de Janeiro: Forense, 2006.

Agências Reguladoras: Legalidade e Constitucionalidade. Revista Tributária e de Finanças Públicas. São Paulo, n. 35, nov./dez. 2000.

GONÇALVES, Pedro; MARTINS, Licínio Lopes Os Serviços Públicos Económicos e a Concessão no Estado Regulador. MOREIRA Vital (org.) Estudos de Regulação Pública. Coimbra: Coimbra, 2004, v. 1.

GORDILlO, Agustín. Tratado de Derecho Administrativo. 7. ed. Belo Horizonte: Del Rey, 2003. t. 1.

. Tratado de Derecho Administrativo. 5. ed. Belo Horizonte: Del Rey, 2003. t. 2.

GRAU, Eros Roberto. O Direito Posto e o Direito Pressuposto. 5. ed. São Paulo: Malheiros, 2003.

. A Ordem Econômica na Constituição de 1988. 9. ed. São Paulo: Malheiros, 2004.

GROTTI, Dinorá Adelaide Musetti. O Serviço Público e a Constituição de 1998. São Paulo: Malheiros, 2003.

HESSE, Konrad. A Força Normativa da Constituição. Tradução: Gilmar Ferreira Mendes. Porto Alegre: Fabris, 1991.

JUSTEN FILHO, Marçal. Curso de Direito Administrativo, São Paulo: Saraiva, 2005.

. Teoria Geral das Concessões de Serviço Público. São Paulo: Dialética, 2003.

. O Direito das Agências Reguladoras Independentes. São Paulo: Dialética, 2002.

. Direito Regulatório. GUIMARÃES, Edgar (coord.) Cenários do Direito Administrativo - Estudos em Homenagem ao Professor Romeu Felipe Bacellar Filho, Belo Horizonte: Fórum, 2004.

. O Poder Normativo das Agências Reguladoras. Rio de Janeiro: Forense, 2006.

KHUN, Thomas. A Estrutura das revoluções científicas. 8. ed. São Paulo: Perspectiva, 2003.

LAUBADÈRE, André de. Direito Público Econômico. Coimbra: Almedina, 1985.

LOEWENSTEIN, Karl. Teoria de la Constitución. 2. ed. Barcelona: Ariel, 1986. 
LOSS, Giovani R. Contribuições à Teoria da Regulação no Brasil: Fundamentos, Princípios e Limites do Poder Regulatório das Agências. ARAGÃO, Alexandre dos Santos (coord.). $O$ Poder Normativo das Agencias Reguladoras. Rio de Janeiro: Forense, 2006,

MACHADO, Santiago Muñoz. Tratado de Derecho Administrativo y Derecho Público General. Tomo I. Madri: Thomson-Civitas, 2004.

MARQUES NETO. Floriano Peixoto de Azevedo. Regulação Estatal e Interesses Públicos, São Paulo: Malheiros, 2002.

A Nova Regulação Estatal e as Agências Independentes. SUNDFELD. Carlos Ari (coord.) Direito Administrativo Econômico. São Paulo: Malheiros, 2002.

Pensando o Controle da Atividade Estatal. GUERRA, Sérgio (org.). Temas de Direito Regulatório. Rio de Janeiro: Freitas Bastos, 2004.

Limites à abrangência e à intensidade da regulação estatal. MOREIRA, Vital; JUSTEN FILHO, Marçal; MOREIRA, Egon Bockmann (coord.). Revista de Direito Público da Economia. Belo Horizonte, 1/69, jan.-mar./2003.

MARTÍN, Carlos de Cabo. Sobre el concepto de ley, Madri: Trotta, 2000, p. 19.

MARTINS, Margarida Salema d'Oliveira. O princípio da subsidiariedade em perspectiva jurídico-política. Coimbra: Almedina, 2003.

MATTOS, Paulo Todescan Lessa. Autonomia Decisória, Discricionariedade Administrativa e Legitimidade da Função Reguladora do Estado no Debate Jurídico Brasileiro. ARAGÃO, Alexandre dos Santos (coord.). O Poder Normativo das Agências Reguladoras. Rio de Janeiro: Forense, 2006.

MEDAUAR, Odete. O direito administrativo em evolução. São Paulo: RT, 2003.

MELlo, Celso Antônio Bandeira. Curso de Direito Administrativ., 19. ed. São Paulo: Malheiros, 2005.

Discricionariedade e Controle Jurisdicional. 2. ed. São Paulo: Malheiros, 2001.

MONCADA, Luís S. Cabral de. Direito Econômico. 3. ed. Coimbra: Coimbra, 2000.

MOREIRA, Vital. Auto-regulação profissional e administração pública. Almedina: Coimbra, 1997.

; MAÇÃS, Fernanda. Autoridades Administrativas Independentes - Estudo e Projecto de Lei-Quadro. Coimbra: Coimbra, 2003.

MOREIRA, Egon Bockmann. Processo Administrativo - Princípios Constitucionais e a Lei 9784/1999. 2. ed. São Paulo: Malheiros, 2003. 
. O Direito Administrativo da Economia, a Ponderação de Interesses e o Paradigma da Intervenção Sensata. Estudos de Direito Econômico. Belo Horizonte: Fórum, 2004.

- Os Limites à Competência Normativa das Agências Reguladoras. ARAGÃO, Alexandre dos Santos (coord.). O Poder Normativo das Agências Reguladoras. Rio de Janeiro: Forense, 2006.

Agências Administrativas, Poder Regulamentar e o Sistema Financeiro Nacional. Estudos de Direito Econômico. Belo Horizonte; Fórum, 2004.

MOREIRA NETO, Diogo de Figueiredo. Direito Regulatório. Rio de Janeiro: Renovar, 2003. . Mutações do Direito Público. Rio de Janeiro: Renovar, 2006.

MOTTA, Paulo Roberto Ferreira. Agências Reguladoras. Barueri: Manole, 2003.

NESTER, Alexandre Wagner. Regulação e Concorrência (compartilhamento de infraestruturas e redes). São Paulo: Dialética, 2006.

NOVAIS, Jorge Reis. Contributo para uma teoria do Estado de Direito - do Estado de Direito liberal ao Estado social e democrático de Direito, Coimbra: Coimbra, 1987.

NUNES, Antônio José Avelãs. Os sistemas econômicos, Coimbra: Coimbra, 1994. . Adam Smith e a teoria da distribuição do rendimento. Coimbra: Coimbra, 2003.

NUSDEO, Fábio. Curso de economia. 3. ed. São Paulo: RT, 2001.

OTERO. Paulo. Privatizações, Reprivatizações e Transferências de Participações Sociais no Interior do Sector Público. Coimbra: Coimbra, 1999.

. Legalidade e Administração Pública - O Sentido da Vinculação Administrativa à Juridicidade. Coimbra: Almedina, 2003.

PIÇARRA, Nuno. A Separação dos Poderes como Doutrina e Princípio Constitucional - um contributo para o estudo das suas origens e evolução, Coimbra: Coimbra, 1989.

PINHEIRO, Armando Castelar; SADDI, Jairo. Direito, Economia e Mercado. Rio de Janeiro: Elsevier, 2005

PRADO, Luiz Regis. Curso de Direito Penal. Parte Geral. São Paulo: RT, 1999.

QUADROS, Fausto de. O princípio da subsidiariedade no direito comunitário após o tratado da União Européia. Coimbra: Almedina, 1995.

RIVERO, Jean. Direito Administrativo. Coimbra: Almedina, 1981. 
SALDANHA, Nelson. Formação da Teoria Constitucional. 2. ed. Rio de Janeiro: Renovar, 2000.

SALOMÃO FILHO, Calixto. Regulação da Atividade Econômica (princípios e fundamentos jurídicos). São Paulo: Malheiros, 2001.

. Regulação e Desenvolvimento. SALOMÃO FILHO, Calixto. (coord.) Regulação e Desenvolvimento. São Paulo: Malheiros, 2002.

. Direito concorrencial - as condutas. São Paulo: Malheiros, 2003.

- Globalização e Teoria Econômica do Conhecimento, SUNDFELD. Carlos Ari; VILHENA, Oscar (coord.) Direito Global. São Paulo: Max Limonad, 1999.

SANTOS, António Carlos dos; GONÇALVES, Maria Eduarda; MARQUES, Maria Manuel. Direito Econômico. 4. ed. Coimbra: Almedina, 2001.

SARAIVA, Rute Gil. Sobre o princípio da subsidiariedade (gênese, evolução, interpretação e aplicação). Lisboa: Associação Académica da Faculdade de Direito de Lisboa, 2001.

SILVA, Vasco Manuel Pascoal Dias Pereira da. Em busca do acto administrativo perdido. Coimbra: Almedina, 2003.

SOUSA, António Francisco de. Conceitos Indeterminados no Direito Administrativo. Coimbra: Almedina, 1994.

SOUTO, Marcos Juruena Villela. Direito Administrativo Regulatório. Rio de Janeiro: Lumen Juris, 2002.

SUNDFELD, Carlos Ari. Direito Administrativo Ordenador. São Paulo: Malheiros, 2003.

STIGLER, George J. Teoria da Regulação Econômica, MATTOS, Paulo (coord.) Regulação e Democracia. São Paulo: 2004.

TÁCITO, Caio. Evolução História do Direito Administrativo - notas de aula, in Temas de Direito Público. v. 1. Rio de Janeiro: Renovar, 1997.

. Do Estado Liberal ao Estado do Bem-estar Social, in Temas de Direito Público, v. 1, Rio de Janeiro: Renovar, 1997. 1997. v. 1.

O Poder de Polícia e seus limites, Temas de Direito Público. Rio de Janeiro: Renovar, .Três Momentos da Privatização. Temas de Direito Público (Estudos e Pareceres). Rio de Janeiro: Renovar, 2002. v. 3. 
Comissão de Valores Mobiliários. Poder Regulamentar, Temas de Direito Público (estudos e pareceres). Rio de Janeiro: Renovar, 1997. v. 2.

TORRES, Sílvia Faber. O princípio da subsidiariedade no direito público contemporâneo. Rio de Janeiro: Renovar, 2001.

VENÂNCIO FILHO, Alberto. A Intervenção do Estado no Domínio Econômico - O Direito Público Econômico no Brasil, edição fac-similar da de 1968, Rio de Janeiro: Renovar, 1998.

WEIL, Prosper. O Direito Administrativo. Coimbra: Almedina, 1977. 